\title{
Spooking the System: Re-evaluating Belief Formation through Psychological Disturbance and Supernatural Encounter in Early Modern English Drama
}

\author{
by \\ Melissa Pullara
}

A thesis submitted to the Faculty of Graduate and Postdoctoral Affairs in partial fulfillment of the requirements for the degree of

Doctor of Philosophy

in

English Language and Literature

Carleton University

Ottawa, Ontario

(C) 2019, Melissa Pullara 


\section{Abstract}

This dissertation explores the early modern English stage as a significant site for producing, exploring, and meditating on psychological uncertainty, specifically through encounters between human characters and representations of the supernatural. I argue that the psychological disturbance these encounters engender allows for a re-evaluation of the process and nature of belief formation. Rather than dismiss dramatic supernatural representations as theatrical spectacles void of critical significance, I argue that the supernatural can be productive conduits for exploring the psychological complexities of the human mind. I demonstrate that because ghosts, devils and witches are products of the same theological and philosophical systems which conceptualize the workings of the early modern mind, they are able to infiltrate and influence the aspects of human psychology which are particularly susceptible to doubt and desire. These encounters then result in the psychological unravelling of human characters, who must navigate conflicting ideals in order to move towards action. However, the experience of this internal struggle is significant not only for revealing the competing influences characters must reconcile in the process of forming beliefs and opinions, but also for emphasizing the importance of critical evaluation of the discourses of belief that surround them, regardless of external pressure to blindly accept them. As ghosts, devils and witches are supernatural figures rooted in the religious, social and political ideologies that shape early modern English belief, so are they imbued with a powerful potential to shake the foundations of those belief systems of which they themselves are part. I analyze supernatural representations of these figures in plays by Shakespeare, Middleton, Marston, Chapman, Goffe and Marlowe, and the psychological effects of their encounters with human characters, in order to examine how they can facilitate alternative perceptions of beliefs around gender and power in sixteenth and seventeenth-century England. 


\section{Acknowledgements}

I would like to start off by thanking the wonderful faculty, staff and students of the Department of English, who have all contributed to creating such a warm, communal and collegial environment. I feel very lucky to have been part of this department for the last five years, as it has taught me so much about what it means to be a colleague, a teacher, a mentor, and an involved member of an academic community. I would like to extend thanks particularly to Dr.

Julie Murray and Dr. Brian Johnson, who, in their roles as graduate supervisor, provided invaluable guidance and advice, not only about the degree program and its requirements, but about life in academia beyond the PhD. Thank you for always having an open door, a welcoming demeanor, and the patience to reassure me through the various bumps along the way. Thank you also to Lana Keon and Priya Kumar, the superb graduate administrators who always have all the answers, whose tireless efforts make life so much easier for the rest of us, and who are always available for a hug or a pep talk. I would also like to thank the internal members of my dissertation committee, Dr. Micheline White and Dr. Donald Beecher, for their critical insight and for helping me to advance my project to the point of completion.

As doctoral students, we are often warned about the potentially isolating effects of the $\mathrm{PhD}$, particularly during the dissertation-writing process. This, however, was not my experience, and I owe that to the immense support of family (especially my mom and sister) and friends who have been by my side throughout this time. Thank you for the generous care packages full of study snacks, writing dates around the city, movie marathons, board games nights, weekend visits, and the willingness to talk me through any one of my numerous moments of self-doubt. Because of you, I found the motivation and determination to push through the most frustrating days, and the confidence to celebrate the milestones. 
Finally, thank you to my supervisor, Dr. Travis DeCook for agreeing to take this supervision on with relatively short notice and in spite of the fact that my proposed topic was outside his usual areas of study. By doing so, he helped me salvage a project I was ready to abandon, and fostered a confidence in my abilities as a researcher, a writer, and a critical thinker I had nearly lost. I thank him for his time and effort in providing thorough feedback, thoughtprovoking questions, and meaningful discussion, and for never hesitating to give advice and support for academic ventures beyond the degree itself. Under his supervision, I have become a more confident scholar and a more proficient academic, and I thank him for helping me see this thing through to its conclusion. 


\section{Table of Contents}

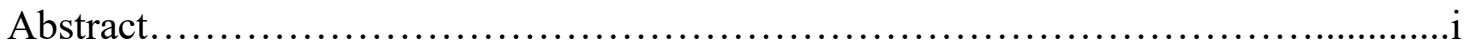

Acknowledgements.....................................................................

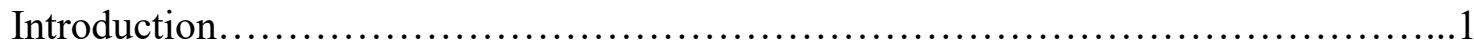

Chapter One: Paternal Ghosts and the Psychological Burden of Filial Obligation..... 30

1.1 The Ghost in Early Modern England............................ 30

1.2 The Ghost in Early Modern Drama................................. 36

1.3 The Ghost of Old Hamlet.......................................43

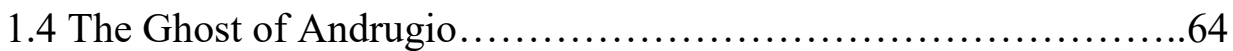

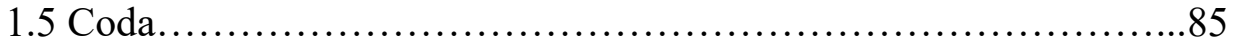

Chapter Two: Beloved Ghosts and the Gender Complexities of Desiring Death.........87

2.1 The Ghost in Early Modern England and English Drama England

2.2 The Lady's Ghost.............................................95

2.3 The Ghost of the Guise..............................................

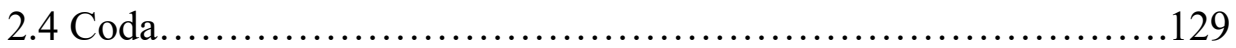

Chapter Three: Devils and the Dissolution of Identity............................132

3.1 The Devil in Early Modern England...............................136

3.2 The Devil in Early Modern Drama...............................139

3.3 The Doctor and the Devil....................................... 150

3.4 The Penitent and the She-Devil..................................181

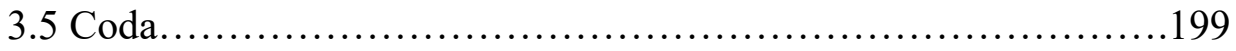

Chapter Four: Early Modern Manhood and the Making of the Witch................203

4.1 The Witch in Early Modern England..............................206

4.2 The Witch in Early Modern English Drama........................211

4.3 The Witch, Gender and the Patriarchy...........................213

4.4 The Weird Sisters................................................. 217

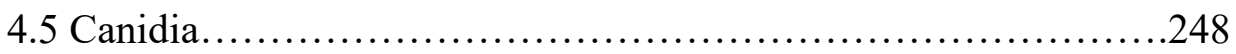

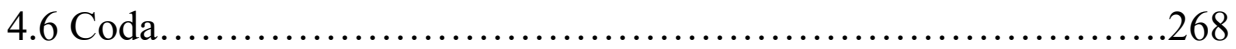

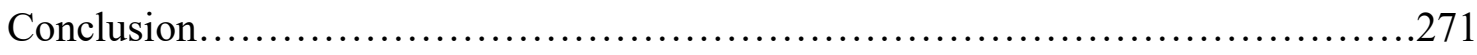

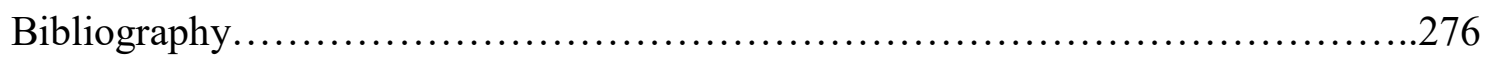




\section{Introduction}

This dissertation explores the early modern English stage as a significant site for producing, exploring, and meditating on psychological uncertainty, specifically through encounters between human characters and representations of the supernatural. I demonstrate that through the mental upheaval they engender, these dramatic encounters offer an outlet for critically re-evaluating widespread ideologies which shaped the belief systems that defined early modern English society. However, these interactions are more than merely a means to reconsider various facets of the social order; rather, I argue that the process and nature of the psychological disturbance these interactions produce is equally important for analysis. It is by examining the form of characters' internal struggle to make sense of competing modes of external thought that readers and audience can understand the significance of the nature of belief - that what characters believe affects how they live, and thus it is crucial that they critically examine the belief systems to which they are exposed, and which dominate the societies in which they live. Drama, thus, becomes a space where playwrights can use contemporary discourses on theological, political, and social beliefs to highlight the problematic nature of people accepting external impositions of belief without undertaking critical questioning about what they believe and why.

I argue that supernatural entities, namely ghosts, devils, and witches, are particularly effective in facilitating the re-examination of human characters' perceptions and attitudes because of their ability to rupture the psychological stability of these characters. Because the supernatural exists beyond the limits of human comprehension and control, its unsuspected appearances uproot a person's internal stability, not only by complicating characters' ideas about reality, but more significantly, by leaving them vulnerable to psychological uncertainty in regards to their own beliefs. Drama proves especially effective in externally manifesting the 
characters' internal struggles with the world in which they live-such that people can witness, and by extension come to their own internal realizations about, the complex psychological journeys that they undergo while experiencing, evaluating, and even attempting to adhere to the various systems of belief which influence all aspects of everyday living.

My discussion of the supernatural in early modern England will focus on dramatic representations from a range of Elizabethan and Jacobean plays (by various playwrights), which I distinguish from contemporary non-fictional records that relay supernatural encounters. I argue that there is a limited degree to which we can discern the psychological effects of the supernatural in real-life accounts, as they are third-person retellings, often imbued with the author's bias, and rarely consider the internal life of the human party or the nature of the supernatural entity itself. For example, the examinations of three accused witches at Chelmseford, Essex in the late 1580s are relayed in the third person by a prosecutor who objectively recounts only the facts provided by the women being interrogated. Joan Cunny, for example, recalls that, "two Sprites did ap|peere vnto her... in the similitude and likenes of two black Frogges, and there demaun|ded of her what she would haue, beeing readye to doo for her what she would desire, so $\mathrm{y}^{\mathrm{t}}$ she would promise to giue them her soule for their trauaile, for otherwise: they would doo nothing for her. Wher-upon she did promise them her soul" (The apprehension and confession, 3). Not only is this not Joan's voice, it is a paraphrased version of her speech; readers, therefore, are given minimal insight into Joan's reaction to the spirits and to her motivations for summoning them. Instead, the pamphlet treats her extraordinary experience as a record of facts alone, and in doing so overlooks her humanity — that she is not merely a witch accused and convicted, but a woman, a person whose engagement with the supernatural cannot be captured within the boundaries of her interrogator's damning questions. Furthermore, 
the account, which focuses largely on Joan's deeds, provides little description of the spirits themselves beyond their frog-form. Like Joan's, the spirits' speech is usurped by the author of the record, and so we get a sense of what happened, but not how or why. What is it about the spirits that enticed Joan to surrender her soul? What did she consider when making her decision — did she reason through her options or was she driven by emotion and impulse? These are significant considerations about an unusual human experience that real-life records tend to omit.

I argue that drama is the most effective medium for exploring the critical significance of the supernatural in a more creative way. One of the many ways Renaissance playwrights hold the mirror up to nature is by facilitating empathetic human responses to difficult and/or disturbing situations, which the audience/readership can experience firsthand. Ronald Levao supports the notion that drama can be an effective medium for exploring how characters react to, are affected and shaped by such circumstances. He observes that "Shakespeare's historical and tragic worlds neither affirm nor deny Tudor visions of order...they concentrate, rather, on what is at stake in the mind's longing to behold, or to challenge, such visions" (256). T.F Wharton similarly notes that Jacobean drama sought not to find solutions to the socio-political problems it exploited, but rather it "suggested new areas of enquiry for the inquisitive minds who became its central figures" (3). Both Levao and Wharton highlight Renaissance playwrights' concern with the psychology of their characters above even the plot of the play, and it is this in-depth mental exploration that allows drama to address intimate aspects of the human experience, the surface of which contemporary records only skim.

Drama's advantage also comes from its ability to affect both the characters within the play world and those outside of it; the audience feels the same shock and horror when Hieronimo 
unveils the corpse of his dead son at the end of Kyd's Spanish Tragedy as the Spanish King and Portuguese Viceroy onstage. It is the unexpected moments in a new play that connect the audience to the characters and so make drama such an effective and powerful psychological instrument. Devices like dramatic suspense and surprise engender spontaneous feeling, which Karen Horney notes signifies the revelation of the "real self" (402). Consequently, Garrett Sullivan Jr. argues that dramatic soliloquies are often inadequate depictions of internal selfhood because they actually allow characters to conceal their authentic feelings through performance rhetoric, without another presence to provoke otherwise genuine reactions more conducive to genuine self-display (68). I argue that by unearthing similar feelings in the characters they encounter, supernatural entities on the early modern stage should be given more critical attention as a site which allows characters to both critically explore and at times supersede the discursive boundaries that limit contemporary self-perceptions, so that they might experience feelings and confront viewpoints which are alternative to socio-political assumptions about human nature and ability, and the dynamics of the world they inhabit.

\section{Role of the Supernatural in Elizabethan/Jacobean England}

At the start of his book The Invisible World: A Study of Pneumatology in Elizabethan Drama, Robert West claims, "it cannot be denied that in 1601, Englishmen...were seriously aware in a way that we are not, of an invisible world about them, and that they spent an appreciable share of their time thinking and writing on spirits and on those affairs of men in which spirits were believed to join" (2). I think West is right in hitting on the threshold between the Elizabethan and Jacobean periods as a key moment for thinking about the impact of the supernatural in social and literary discourses; however, English acknowledgement of the 
"invisible world" obviously extended far beyond the horizon of the seventeenth-century. ${ }^{1}$ P.G. Maxwell-Stuart notes that the existence of spirits was so normalized that both Catholics and Protestants "took for granted the reality of a preternatural world of non-human beings who were capable with God's permission of interfering in, modifying or changing the regular laws of nature" (184). This was because, despite the political and religious tumult that plagued England between the medieval and early modern periods, it remained a place where religion held enormous sway. Robert Watson observes that the Christian God became a kind of anchor against the possibilities of mutability in all systems of belief (14). Thus, even as the Reformation reconceptualised the relationship between the individual, the Scriptures and the Almighty, and even as Protestants sought to purge the nation of what they deemed Catholic idolatry and papal corruption, Catholics and Protestants alike were nonetheless inextricably bound by the fact that at the centre of each belief system, regardless of their stance on sacrament or clergy, was God. It was His divine presence that shaped the theological belief in the English Christian world overall.

Following the belief that all things come from God, so, too is He the root of the supernatural hierarchy that follows from Him, extending even into the realms of demons and witches. In his 1593 treatise Of Spectres, Ronald Hutchins argues that specters, which he defines as demons and evil spirits alike (414), are essences "clothed" in form by God and, as such, their presence on earth is sanctioned by Him, as a moral test for those they encounter. It was common for Protestant theologians to suggest that God permitted evil presences to roam the earth in order to strengthen the virtue of His followers against those forces that would seek to endanger their souls (Marshall 199; Chesters 205). The link between these devilish spirits and the Almighty

\footnotetext{
${ }^{1}$ So, too, has the discourse of "the invisible world" continued to infiltrate modern discussions of belief, despite popular opinion in "the myth of disenchantment". See Jason A. Josephson-Storm's The Myth of Disenchantment: Magic, Modernity and the Birth of Human Sciences, wherein the author demonstrates that many of the methods and concepts surrounding the idea of "disenchantment" are imbued in key elements of the occult.
} 
results in a long chain of supernatural connection; as Gillian Bennett notes, "apparitions are essential evidence for the existence of witches, witches for devils and devils for Satan, and Satan for God, because all are part of the supernatural hierarchy which tops the Great Chain of Being" (3). Because even the more controversial supernatural figures were products of the Creator, Stuart Clark has argued that it is, in fact, anachronistic, to denote spirits and devils as strictly supernatural figures in the period, as early moderns would have very much seen them as part of the natural realm (Demons 168). ${ }^{2}$ Indeed, in addition to categorizing spirits as "good" or "bad," early modern demonologists also divided spirits according to elemental factions: belonging to air, fire, water, or earth (Hutchins 419). These invisible presences were, therefore, not merely spiritual, but also ingrained in the physical English terrain. However, the tie to one of the four elements did not necessarily make these spirits benevolent or benign, as air spirits were often enlisted by witches as familiars (Nashe 9), ${ }^{3}$ and earth spirits, especially, could "seduce human minds and lead them whither they wished and transform them into whatever state of mind they desire" (Hutchins 421). The constant presence of spirits, and the uncertain nature of their purpose or intent towards humans, contributed to widespread warning in ministries across England for people to be vigilant in their dedication to God and His good works, as everyday life carried with it the potential to be lead, even unwittingly, into the devil's trap.

While Christianity in general focused on God as the head of earthly and supernatural hierarchies, the turn towards Protestantism brought with it an increased awareness of people's susceptibility to sin (Burnet 113), ${ }^{4}$ and people were charged more than ever with monitoring their

\footnotetext{
${ }^{2}$ Clark also observes that demonology as a discourse and discipline was very much entwined with early modern natural philosophy (Demons 168).

${ }^{3}$ An example of this is in Shakespeare's The Tempest with Ariel, whose very name indicates he is an air spirit.

${ }^{4}$ See Burnet's elucidation of article seventeen of the Church of England's thirty-nine articles, in which he details the doctrine of election and the natural tendency of humans to sin, rather than be virtuous.
} 
internal, as well as their external, lives in order to fortify themselves against temptation (103). Maxwell-Stuart notes how the Reformation "made the intense and minute scrutiny of divine omnipotence of the utmost importance to human sensibilities heightened by their awareness on one hand of God's overwhelming power, and on the other, of their own...proclivity to sin" (173). It was this acknowledgement of humanity's inherent moral weakness which Brian Levack argues contributed to the rise in witchcraft persecutions after the Reformation- the belief in the constant threat of the devil likewise lent many to see his influence in others more blatantly than they might have before (Witch-hunt 178). However, Levack also observes that this selfsurveillance against the forces of evil required a moral rigour which "took a heavy psychological toll" (106). The result was a religious melancholy which could manifest as despair-a doctrine upon which I elaborate in chapter three - especially with the introduction of Calvinist election, as people became plagued by fears about their own salvation. Somewhat ironically, people of melancholic disposition were thought to be more susceptible to the devil (Dreher 36$),{ }^{5}$ so those concerned with their spiritual fate would then be additionally tasked with preventing their internal doubt from leading them into the throes of the devil, who preyed on the vulnerabilities of those who believed they were reprobate. By contrast, Martin Luther argued that this struggle with the devil was necessary in order to strengthen faith in God (Cameron 168) - temptation and the experience of despair were thus key facets of maintaining the hope that a person was saved. ${ }^{6}$ Adrian Streete observes that Luther's claims provide one example of the ways in which Protestantism creates human subjects by placing the human in opposition to the divine (40), so

\footnotetext{
${ }^{5}$ This relationship also operated inversely, as it was thought that those who were prone to melancholy were so because they were under the influence of the devil, or were reprobate (Dreher 42)

${ }^{6}$ Luther, likewise, argued that it was the godly who were foremost prone to temptation because God knew they were innately equipped to handle such moral tests (Cameron 123), and that by "by focusing greater temptations on individuals, [God] allowed them an implicit knowledge of their election" (114); see also Nathan Johnstone's book on the devil's influence in the period, cited in the bibliography.
} 
the very fact of being human in the early modern period becomes dependent on an individual's engagement with various supernatural forces.

The degree to which people were expected to accept their sinful nature but actively combat it, and to remain wary of the devil in all things while nonetheless praising God's goodness, created a realm of psychological uncertainty which had various effects on the period's relationship with the supernatural. There were several arenas where, as is apparent in matters of election and despair, the ideas people were supposed to accept seemed inherently contradictory or, at the very least, difficult to reconcile internally. In other cases, the views promoted by the Church did not reflect popular practices and belief, creating a stratum of opinions about the existence and nature of different supernatural figures, as well as the roles they might play in everyday life. The most divisive example of this was arguably the ghost, of which many Protestants were skeptical, assuming any apparition was more likely a devilish illusion than actually the soul of a dead loved one returned to earth. But despite this caution against ghostbelief, ghost sightings and encounters continued to spread at the local level, so Reformers struggled to eradicate ghost belief entirely. The discourse surrounding witch belief, too, was imbued with multiple viewpoints which made it difficult for one to ascertain the 'truth' of what or who might be considered a witch, if, indeed, they could be said to exist at all. Even as England experienced a wave of witch-hunts, in the 1590s and 1640s in particular, there were vocal skeptics like Johann Weyer in On the Tricks of Devils (1563), where "early modern skepticism about witchcraft found its first major voice" (Clark 125), and Reginald Scot, whose Discoverie of Witchcraft (1584) aimed to discredit accusations of witchcraft by denying the existence of witchcraft at all—citing a lack of evidence in the Bible as well as identifying the false confessions means like torture and intense interrogation might elicit (10). The mixed attitudes 
towards the supernatural were evident in other related areas as well, such as questions

surrounding prophecy and whether any human could be said to have true foreknowledge. While governing authorities issued bills against prophecy, making it a punishable crime in 1559, 1563 and 1580 (Smith 161), ${ }^{7}$ Queen Elizabeth herself kept close relations with John Dee, an astrologer who was known to engage in prophecy and divination (164).

Just as questions surrounding the supernatural distinguished the denial of spirits in official doctrine from ongoing belief in them at the local level, so, too, did they reinforce class divisions along similar lines. Timothy Chesters notes that in the second half of the sixteenth century, elite members of society sought to differentiate themselves from what was seen as a strictly 'peasant' belief in ghosts (7). As witch persecutions spilled into the Jacobean period, they, too, came to be seen as a more "rural phenomenon", a product of the superstition of the less educated class, and so elites became more skeptical about such accusations, which, indeed, resulted in fewer convictions (until the 1640s at least, when the hunt spiked again) (Levack 129). ${ }^{8}$ And yet, despite the increase in critical re-evaluation of supernatural belief at the higher levels of the social strata, there continued, even until the end of the seventeenth-century, to be a proliferation of records about various encounters with ghosts and devils-some of which I discuss in the chapters that follow.

\footnotetext{
${ }^{7}$ It is intriguing to note that these dates correspond closely to the different statutes against witcheraft, which I discuss briefly in chapter four. This may not be coincidental, however, as Bart Van Es observes that prophecy proliferated primarily in times of crisis (as did the witch persecution); he cites Keith Thomas' claim that "prophecies of one kind or another were employed in virtually every rebellion or popular rising which disturbed the Tudor state" (Van Es 2000: 11). Just as witches could provide scapegoats against whom struggling institutions might unite their constituents, so prophecy, a belief in something to come, allowed people to experience a sense of truth in times of chaos.

${ }^{8}$ See also Malcolm Gaskill's chapter for more information about how witch hunts targeted the poor specifically, often because they were at an economic disadvantage and dependent on others (therefore vulnerable to the whims of patrons who might at any time decide they were a burden of which to dispose), as well as their limited access to legal resources.
} 
Supernatural belief was, thus, an ongoing and omnipresent element of early modern English society, one that persisted in confronting people with doubt about how to distinguish reality from illusion, truth from deception. This is significant in terms of the social implications for supernatural figures which were often depicted as foreign threats to particular systems of thought. Acknowledging the possibility of ghosts proper (i.e. souls of the dead returned to earth) would challenge Protestant claims against their existence, and the witch risked encouraging the desperate and woe-begotten (women in particular) to turn to solutions outside the bounds of acceptable conduct set by patriarchal authorities in order to imbue themselves with power those authorities otherwise deny them. There is, therefore, a problematic contradiction between this depiction of the supernatural as a threat to prevailing cultural interpretations of those belief systems, and the fact that conceptions of the supernatural stem from within those same systems. My dissertation argues that playwrights use their supernatural characters to underscore the nature of this discrepancy. Early modern dramatists integrate conventional character tropes, like the mischievous devil, the lusty witch, and the revenge ghost into their portrayals of the supernatural in order to demonstrate that such stereotypes are artificial constructions which are meant to ostracize figures that, in fact, are innate to the religious and political ideologies which dominate early modern life.

\section{The Supernatural and Psychological}

Just as the supernatural was ingrained in the very fabric of everyday living, so, too, was it a part of early modern psychology. The early moderns did not have one designated discipline for psychology as we do now; rather, what we now call psychology composed several areas of study, from physiology and medicine to theology and philosophy. It should also be noted that the 
word "psychology" was not actually used in the sixteenth and seventeenth centuries. The early moderns were familiar with what modern sensibilities understand to be psychological concepts, such as affect, behaviour, will, and intention. However, each of these strains were treated differently, as they were ascribed to different physiological, moral and mental systems, and so studied according to their affiliated disciplines. Affect, for example, was a matter relating to the passions, which were external manifestations of a person's internal reaction to sensitive stimuli. As such, affect was a matter of the sensitive soul, and so discussed in terms of physiological signs. For example, in his Discourse of ciuill life (1606), Lodowick Bryskett explains physical blanching in terms of mental effect:

Feare which proceedeth from imagination of some evill to come and is at hand, maketh the mind which conceiveth it to startle, and looking about for a meanes of defence, it caleth out the blood into the innermost parts, specifically to the heart, as the Chief Sort of castle, whereby the exterior parts being abandoned and deprived of heat [from the blood], and of that colour which it had from blood and the spirits, there remaineth nothing but paleness (55-56).

On the contrary, will was conceived of largely in religious terms, particularly in the debates, such as those in which Erasmus and Martin Luther engaged, over the amount of free will a person could be said to have under the terms of Protestant predestination. ${ }^{9}$ But in the pages that follow, I use the term psychology, anachronistic though it may be, to discuss varying mental phenomenon, such as will, appetite, affect, and a character's cultural and moral internal understanding of his or her external world. My aim in doing so is to provide an overarching view of the various facets of the early modern mental world, and to explore how the supernatural was able to affect a character's internal perception in multiple ways, by exposing, infiltrating, and influencing the several belief systems which composed the early modern subject.

\footnotetext{
${ }^{9}$ See Erasmus' On Free Will and Luther's On the Bondage of Will for their scholarly debates with the work of the other on the subject of the free human will, which Ernst F. Winter has edited alongside one another in his edition Discourse on Free Will: Desiderius Erasmus and Martin Luther.
} 
Much of the early modern understanding of what we now call psychology stemmed from the work of Claudius Galen, the ancient physician who emphasized the power of the four bodily humours in determining a person's state of mind - the humours could be influenced by changes both inside and outside of the body and fluctuation of the humours dictated changes in an individual's emotional disposition (Lamarra 2012). The melancholic humour, which presented itself in the body in the form of black bile, was particularly significant for experiencing the effects of supernatural forces. Those of melancholic disposition were thought to attract devils, spirits, ghosts etc. (Rossky 56). In his Treatise of the Passions, Thomas Bright, too, observed that melancholy could contribute to "blacke forms and strange visions" (qtd. in Fudge 6) — thus, it was arguably the most dangerous humoural state because of how vulnerable it made people to supernatural influence. The potential psychological experience of the supernatural was, thus, not only related to external stimuli, but existed within the realm of the body itself. ${ }^{10}$

Galenic scholarship flourished alongside the resurgence of Aristotelian philosophy. Aristotle famously postulated that a person's internal existence is composed of and controlled by a three-part soul — the rational (which housed the mental faculties like imagination and memory), the vegetative (which pertained more to bodily consumption, production and reproduction) and the sensitive (the seat of the passions as well as the Appetite, which contained our desires, the

\footnotetext{
${ }^{10}$ Supernatural and physiological discourses further entwined because of what the early moderns call animal or vital "spirits": "whenever the soul remembered something, animal spirits transported a memory image from the hindmost to the foremost part of the brain, for consideration by the imagination" (Long 162). Mary Floyd-Wilson cites Leonardus Lessus, who argues that the animal spirits seemed to have their own kind of agency to "govern and order" the body; but if clogged or delayed in their movement by other bodily obstructions, one could lose communication between rational and sensitive soul, i.e. the ability to create meaning from external stimuli (139). According to Lessus, this delay creates internal fragmentation, so animal spirits were responsible for internal order much like divine spirits were responsible for external order (139). Fernando Vidal also argues for a key connection between body and soul through the animal spirits, as cold spirits would likewise cool a person's blood, the result of which would be a slow-thinking mind (35). Moreover, in the fifteenth century, Marcus Ficino (whom I mention in subsequent chapters) postulated a connection between the vital spirits and the soul, claiming that it is through these spirits that the soul is able to master control of the body (qtd. in Giglioni 28).
} 
Will etc.) (Kemp 1996). According to Aristotle, the rational soul was exclusive to humans, and it was charged with tempering the passions as well as processing the empirical information gathered from the senses. However, like the bodily humours which had the potential to diminish the strength of the mind and so make one more vulnerable to the negative effects of supernatural forces, so was the rational soul imbued with the same possibility, particularly via the imagination. Of all the mental faculties, the imagination was thought to be the most likely conduit for demonic spirits, especially when a person was sleeping and his/her critical thinking functions immobilized (Mandel 61). The dream world blurred boundaries between possible and impossible worlds, and it was through imaginative dream that the devil could most successfully infiltrate the mind and influence the mental state—and so tarnish the soul—of his victims (61). ${ }^{11}$

This Aristotelean link between the mind and the soul continued into the Middle Ages and the Renaissance. In the last third of the sixteenth-century, the word psychologia was first used by Protestant Scholastics like Petrus Ramus to describe the process of examining facts in order to better understand entire academic disciplines (Vidal 21). The word itself stems from the Greek word psychogama which means "the generation of the soul" (Vidal 26). Ramus' initial use of the word was reconfigured to connote the examination not of things, but of people; Spanish Jesuit Rodrigo de Amiga later used it in reference to "the science of the soul", noting that knowledge of the soul through scrutiny would help to guide human behaviour (Vidal 23). The early modern predecessor to modern psychology was understood as an extension of spirituality, where people might cleanse their souls by undertaking the self-examination of their own internal (particularly moral) characters. In so doing, a person could garner knowledge of the self while simultaneously becoming closer to God.

\footnotetext{
11 There is another notable connection between mind and supernatural in the concept of nightmare, mythically thought to occur because an old hag (a witch figure) was sitting on a person's chest as they slept (Fudge 6).
} 
Even as the understanding of the term psychologia evolved from a theological framework to concerns with human nature more generally, moral consideration of the self nonetheless remained an integral component (Vidal 29). Early modern understanding of consciousness has similar supernatural origins; the word stems from the theological conscience which itself is a product of the Latin conscientia which "expressed an awareness of the moral distinction between good and evil, and therefore the subjective capacity to judge an individual's own behaviours" (Lamarra 312). The roots of human psychology, as it was understood in sixteenth and seventeenth-century England, were steeped in morality—how the consideration of the state of a person's soul determines his/her behaviours and actions. In this way, early modern conceptions of psychology were linked to the supernatural by way of their mutual connection to the state of the soul—psychology through the three-part soul (especially the rational soul which was the part believed to survive after death and so live on into the afterlife), and the supernatural through its theological foundations. As such, the soul became the means by which the supernatural might be thought to affect an individual's psychology. A melancholic was assumed to have a weak rational soul, the melancholic humour breaking down the strength of reason and giving way to imagination, which then allows the devil to influence a person's thoughts beyond the bounds of what one might otherwise consider to be right or good. As such, diabolic possession evolved from being catalogued as a physical affliction to a psychological one, an internal, mental battle for the soul (Sluhousky 7). ${ }^{12}$

It is evident, then, that the supernatural and the psychological in early modern England were physiologically and theologically linked. Establishing this connection provides an historical

\footnotetext{
${ }^{12}$ See also Stuart Clark's discussion of Aquinas's belief in the devil's ability to take over inner senses of people and create pseudo- or alternative realities (125), as well as Vanities of the Eye, where he cites Petrus Martyr's Loci Communes (1576) which details how the devil was believed to be able to create visual phenomena in the brain itself (244).
} 
foundation upon which I build my central thesis - that examining the role of the supernatural is a productive means of understanding the psychological processes these dramatic characters undergo in evaluating the world around them. Such a connection reveals that figures like ghosts, witches, and devils can be potent influences on characters' psychology because, in addition to being part of a supernatural hierarchy born from the same theological system which governs the actions of the soul, they operate primarily by seeking to influence the characters' souls — whether through the 'infection' of one rational soul to another, as I will discuss in chapters one and two, or through seeking to corrupt the moral soul through temptation. Because the tri-part soul was the central means by which a human understood and perceived their external environment, the supernatural's ability to permeate it by way of their shared spiritual (and in the case of ghosts, rational) roots suggests that these characters are naturally susceptible to supernatural influence through their very bodily - if we consider the dangers of humoural imbalance, particularly in regards to melancholy, for example - and spiritual make-up. My dissertation investigates how early modern plays explore this connection and reveal it to be a critical site for producing a psychological disturbance which makes people perceptible to possibilities that extend beyond what one has become accustomed to think or believe.

\section{Making the connection in early modern drama}

Where it was difficult for pamphleteers recording supernatural encounters to provide a detailed picture of the psychological impact such interactions had on the victims, especially as theirs were third-person accounts that relied primarily on relaying events, early modern playwrights had the imaginative space of theatre to aid them. ${ }^{13}$ Barbara Traister claims that in the

\footnotetext{
${ }^{13}$ See Robert Reed Jr.'s The Occult on the Tudor and Stuart Stage for a detailed breakdown of the various supernatural characters used in a wide range of plays across the Elizabethan and Jacobean periods.
} 
period, "supernatural manifestations [we]re, of course, a standard code for the operations of conscience" (143), and there are numerous examples where drama uses the supernatural to signify characters' internal guilt, anxiety and worry. Perhaps the most common figure used in such regard is the ghost; for example, in Julius Caesar, Richard III, and Macbeth, the murderers Brutus, Richard and Macbeth are confronted by the ghosts of their victims, and the result is a psychological disruption which, in all three cases, leads to resounding military defeat and death. According to Traister, this defeat comes as a result of the ghost's negative effect on Brutus' and Richard's conviction in their own causes—enabling a self-division which pits the justification of their actions against the morality of them, thereby collapsing the limited view of the self-justifier by providing an alternative world view of the consequences of their actions (145-149). Owen Davies argues that this commentary on reality could only occur through the moral lens, as in his time "Shakespeare could only be taken seriously if his ghosts were mere projections of a disturbed or guilty mind. To have ghosts wandering the stage portraying a reality was too absurd to merit serious contemplation" (218). Questions of right, wrong, good and bad were, thus, perhaps the easiest way for playwrights to integrate supernatural characters into their plays with a purpose larger than acting as mere plot devices or comic tropes. Robert Reed Jr. notes a similar tactic in William Haughton's The Grim Collier of Croydon, where the devil enters the realm of the living in disguise in order to test the moral characters of supposedly lewd women (227). He argues likewise that in The Witch of Edmonton, the devil mentally coerces Mother Sawyer into embracing him and his works, demonstrating the moral weakness of women through "the genesis of a witch, that is, the metamorphosis of a single-minded woman into an alleged practitioner of the black arts" (183). 
However, my exploration of the ways the supernatural functions in regards to its psychological impacts on human characters is less interested in the ways in which these figures might reaffirm dominant ideologies (e.g. murder is bad and women are weak). Instead my focus is on demonstrating how ghosts, witches and devils are more able to disturb and undermine prominent discourses because they exist within systems of morality and theology, ${ }^{14}$ and yet are necessarily ostracized from them because of the threats they pose to those systems. It is because they operate both inside and outside of the system — not only because they are identified as outsiders to order and morality (such is a common belief which was shared among, and so united, all Christians, regardless of sect or doctrine), but also because they are, or in the case of the witch presumed to be, supernatural, and thus inherently beyond limited human comprehension. Their inherent mystery makes them more threatening because they cannot be entirely controlled. The very unknowability of the supernatural, which renders it shocking and destabilizing, limits the degree to which institutions might interpret narratives about these figures in ways that benefit their own influence over belief. Therefore, because the supernatural exists both as part and on the margins of dominant ideals, it can be used as a propaganda tool for authorities seeking belief conformity among its constituents, or as a source of disruption to those authorities by prompting individual minds to think outside the bounds of prescribed belief.

Such is the duality I argue playwrights exploit in their portrayals of ghosts, witches, and devils, which both adhere to conventional belief and yet uproot them through the impact they have on the human characters they encounter. They are able to produce a psychological uncertainty in a person's mind by capitalizing on the innate physiological, moral and spiritual fragilities which make him/her susceptible to doubt—a key aspect of rational thinking which

\footnotetext{
${ }^{14}$ Doris Lessing argues similarly, that Shakespeare saw the ghost as a "natural event... as part of the system of things" (qtd. in Roffe 18) rather than a foreign Other.
} 
authoritative mandates can seek to quash in the name of order. For example, rather than reinforcing discourses surrounding the moral weakness of early modern women, Jonathan Gil Harris points to how Dekker, Rowley and Ford use their drama to "recode" the original, accusatory pamphlet on the case of Elizabeth Sawyer, to "reveal the witch...to be less opposed to, than produced by, the society that brands her a deviant threat" (132). Levao argues similarly about the Ghost of Hamlet, claiming that while it presents a "moral vision" for the play, that vision reveals not the positive state of things, but "the schizophrenia of a dying culture" (339). He relates the ghost's larger revelation to "its primary dramatic force...the way we see it take hold of Hamlet's mind. It is for him a spectral reflection of a world that can no longer reconcile its contradictions" (339). Levao points specifically to the ways in which the ghost's rhetoric is riddled with opposing ideas, particularly as it commands Hamlet to take vengeance against Claudius, and yet condemns murder as a "foul sin"; it further offers a Christian lament for dying without his last rites, and commands Hamlet to keep his mind free from the moral taint and corruption that has evidently overtaken the adulterous Gertrude, and yet it proceeds to relay a detailed tale of her grotesque sins, thereby giving Hamlet little choice but to ruminate on them (339).

I think Levao identifies two significant elements which are key to the ghost's character as well as the role it plays. Not only does it operate through its influence on Hamlet's mind, the nature of which I will examine in more detail in chapter one, but its commands for vengeance have a complicated effect on Hamlet because of the conflicting beliefs it unearths in him. While Levao highlights the moral complications, I believe that the difficulties extend further, to the realm of social and political codes of patrilineality which operate on honour and virtue and yet call for acts of murder in the form of revenge. This is the work of psychological disturbance and 
critical questioning that I believe supernatural characters can perform, beyond being just, as A.P. Rossiter suggests, "vivid symbols for the frontier of the mind" to be treated "as aspects of the protagonist rather than persons-of-the-drama" (220). While some ghosts, witches and devils in early modern drama do largely signify the psychological states of the human characters they encounter, to view them solely as representations_-as "mechanism[s] in the plot of the play and as a means of making its meaning clear, but not part of that meaning" (West Outer 41) — is problematically reductive. It overlooks the significance of the figures as distinct supernatural entities, and their potential to influence characters in certain ways because of the particular aspects of their ontologies, which, in turn, have the potential to reveal distinct truths about human nature and the nature of what people believe.

\section{Scope of the project}

I have chosen to examine theatrical works from the Elizabethan (1558-1603) and Jacobean (1603-1625) eras specifically because they arguably constitute the peak period of early modern English drama— particularly in terms of plays which feature supernatural characters. ${ }^{15}$ This range of time also coincides with a heightened concern with the interior self, as noted by critics like Stephen Greenblatt, in his seminal work on self-fashioning, and James Hirsch, in his discussion on the extent to which the proliferation of soliloquies in Renaissance drama related to increasing popular interest in the internal self(14-19), as well as to the desire to discover the secret, internal thoughts of others (Hanson 2). ${ }^{16}$ Elizabethan and Jacobean drama, therefore,

\footnotetext{
${ }^{15}$ For a comprehensive list of the supernatural characters featured in plays across the early modern period, see $A n$ Index of Characters in Early Modern English Drama: Printed Plays 1500-1660 by Thomas L. Berger, William C. Bradford, and Sidney L. Sondergard, from Cambridge UP, 2015.

${ }^{16}$ Kirsten Poole also notes how the popularity of anatomy theaters contributed to the overall interest in discovering the human interior, both physically and psychologically (11).
} 
provides a large and variant scope of 'supernatural' plays. However, as I want to emphasize the significance of drama specifically as a means for exploring psychological conflict through interactions with the supernatural, it would be insufficient to examine drama alone. Therefore, I also compare supernatural encounters in drama with those relayed in contemporary pamphlets, in order to highlight the creative liberties a playwright might take in their use of the supernatural because the theatre was an inherently imaginative space which allowed for a degree of experimentation and exaggeration. Pamphleteers, however, were more limited in their mandate, charged with relaying the recorded encounters of others in a way that established credibility and authenticity.

I would be remiss, however, to presume that all of the pamphleteers who recorded supernatural encounters lacked creativity and avoided artificial construction in ways similar to sixteenth and seventeenth-century dramatists. Despite their base in supposedly real events, these pamphlets were, nonetheless, narratives much like the plays performed on stage. However, the specific pamphlets I have selected for comparison alongside my literary analyses are explicitly imbued with, more often than not, moral biases which promote conventional expectations of good Christian behaviour. These pamphlets in particular appear less subversive than their dramatic counterparts because they tout standards of conduct that align with the teachings of the Church, where playwrights, like Marlowe for example, delve further into the difficulties underlying adhering to those teachings.

I will also highlight here the temporal discrepancies between the pamphlets and the dramatic works I compare. While the plays at the centre of my literary analyses were written between 1592 and 1618, the comparative pamphlets date nearer to the second half of the seventeenth century. This discrepancy between dates complicates my comparisons, especially as 
the cultural, political, and theological spheres changed drastically between the Jacobean and Caroline periods. I have chosen to proceed with such a comparison, nonetheless, for two reasons. The first reason is that most of the recorded accounts of supernatural events do not appear until close to the middle of the seventeenth-century, so there is an unfortunate lack of primary material to explore before 1600. The second reason is, as I will demonstrate, that despite the time gaps between the pamphlets and the plays, many of the conventions surrounding particular supernatural belief remained consistent, regardless of the changes the external world experienced. Such is evident in the surprisingly similar descriptions, which I will discuss in detail in chapter one, of the Edge-hill ghosts, from a 1641 sighting, and the ghost of Old Hamlet, which Shakespeare wrote at the end of the sixteenth century. While the date discrepancies between pamphlets and plays may appear to create flawed comparisons, I will demonstrate how the interval in publication and performance dates nonetheless reveal an intriguing continuity of belief which survived in spite of the tumultuous changes other belief systems in early modern England experienced throughout the seventeenth-century.

I have decided to focus on ghosts, devils and witches in particular because they are the most prominent supernatural characters to feature both in early modern belief (and likewise, pamphlets and tracts) and drama. Moreover, these three figures are intimately connected within early modern systems of belief - Kathryn Edwards notes the frequency with which ghosts have been studied in relation to witchcraft and demonology (356), and Gillian Bennett further claims “it was simply not possible to separate out one supernatural creature [in] belief or disbelief” (4) because of their interconnectedness. As I will discuss in each respective chapter in more detail, witches were considered minions of the devil, their powers and abilities stemming from him and the pact they made with him in order to obtain such gifts. Protestants often denied the existence 
of ghosts, claiming any apparition to be a trick of the devil; however, as ghost beliefs persisted into the Reformation, people were charged with distinguishing a true ghost from a devilish deception. Ghosts were also one among several possible witch familiars, ensnared by the devil to serve his agent on earth (Bennett 4-5). The three figures are thus ontologically and culturally entwined, and so it is critically productive to analyse their roles in early modern drama alongside one another, especially as they serve similar functions as catalysts for psychological upheaval, being all rooted in the same theological system which prescribed the nature, function, and boundaries of the soul — the nucleus through which people came to understand, and form beliefs about the world they inhabited.

I mentioned that there are numerous plays written and performed between 1558 and 1625 which feature supernatural characters, which means the constraints of this project permits me to analyze only a small fraction of the possible texts. As my goal is to analyze significant encounters between supernatural and human characters, I avoid figures like the ghost of Don Andrea in Kyd's Spanish Tragedy, who spends the entirety of the drama as a marginal voyeur, never directly interacting with any of the human characters. There are some supernatural characters that do seem, in John Jump's words, "mechanical, formulaic" (347) in the purposes they serve, whether as ghosts of conscience or devilish tempters. ${ }^{17}$ Among these I would also include witches like Dipsias in John Lyly's Endymion and the Enchanter in George Peele's The Wisdom of Doctor Dodypoll, both of whom reflect the conventionally lusty appetites of the witch-figure (despite Peele's Enchanter being male and not the female witch caricature) without further purpose. Such figures tend to embody ideological beliefs and not, as John D. Cox

\footnotetext{
${ }^{17}$ In addition to the ghosts of Richard III's victims and Julius Caesar, as discussed previously, there are also Shaw's encounter with the ghosts of Richard's victims in Heywood's II Edward IV, Domitian's dream encounter with the ghosts of his murdered victims in Massinger's The Roman Actor, as well as the devil in Barnabe Barnes' The Devil's Charter who helps the Borgia Pope deceitfully obtain his position and power.
} 
suggests of Marlowe's devils, to conform explicitly to traditional beliefs in order to upend them (46). Instead, they present stereotypical notions of what the witch, ghost or devil should be, whether to facilitate a dramatic conundrum between human characters in which they later play a minimal role, to provide comic or other entertainment value, or, in some cases, to confirm the statutes and beliefs dominant powers have put in place against such figures. ${ }^{18}$ Alternatively, the supernatural characters I focus on in my chapters' dramatic analyses supersede such "mechanical" portrayals, and offer multiple possibilities of signification beyond a simple moral or plot device.

\section{Chapter Summaries}

The first chapter, "Paternal Ghosts and the Psychological Burden of Filial Obligation", explores the various psychological influences the ghosts of Hamlet in Shakespeare's play and Andrugio in Marston's Antonio's Revenge have on the sons to whom they appear in order to avenge their wrongful murders. I argue that the ghosts of Old Hamlet and Andrugio are able to have such profound effects on the eponymous protagonists because of their ontological significance as rational souls uninhibited by the constraints of the body; thus, they are able to create a more potent connection with fellow rational souls, that of their sons in particular, through a process resembling Baconian fascination. The ghosts do this by invoking their patriarchal authority over their sons. The ghost of Old Hamlet recalls for (and in) Hamlet the

\footnotetext{
${ }^{18}$ Other such figures which I found did not necessarily fit the purpose of this project were devils who appeared in disguise to the human characters they encounter (such as in Thomas Dekker's If the Devil's In it and Rowley's The Virgin Martyr), as I believe direct engagement to have different effects than those which result from an unrealized presence. In the case of witch plays, there are a number of intriguing characterizations, including Mother Sawyer in the Witch of Edmonton and Joan in Shakespeare's 1 Henry VI which focus on the psychology of the witch as she navigates being accused and tried for her supposed crimes. However, such portrayals deal less with the interaction between the witch and the devil, or even the witch and her craft, than the mindset of the women who often are not supernatural figures in themselves, as opposed to the Weird Sisters who, for example, seem more supernatural than human.
} 
father's role as the head of the family, who being wrongfully murdered, relies on his son to uphold his honour, as well as that of the whole dynasty, by seeking vengeance against those wrongdoers. The ghost of Andrugio emphasizes the father's role as Antonio's life-giver, the source of his bloodline, to whom he literally owes everything and as such, to whom he must repay his debt through the act of revenge. However, the expectations each paternal ghost places on its son to not only avenge its murder, but to fulfill his social and political potential as inheritors of a great family name and position take a significant psychological toll on both Hamlet and Antonio. In Hamlet's case, the revenge task becomes a psychological obsession which actually deters him from acting, as he becomes consumed by the mental work of remembrance to the extent that ancestral memory and the expectations of patrilineal justice cages him in his own contracting mind. On the contrary, Antonio approaches his revenge task with an overzealous eagerness that borders on murder mania, as he seeks to please his father at any cost, and becomes more emotionally and psychologically child-like in the process. In both instances, the ghosts' memorial invocation of patriarchal authority drive their filial avengers to psychological extremes - in one case, stagnation, and in the other, hysteria — and the result of the burden of navigating these socio-political expectations is an eventual rejection of those codes of inheritance and patrilinearity which cause Hamlet and Antonio such psychological distress. The ghosts, therefore, as manifestations of the memory of patriarchal structure, undermine that same system of authority by influencing their sons to experience the negative and potentially damaging effects the burden of such a system can place on those it relies upon for preservation.

The second chapter, "Beloved Ghosts and the Gender Complexities of Desiring Death", focuses on the ghost of the Duke of Guise in George Chapman's Revenge of Bussy D'Ambois and the ghost of the Lady in Thomas Middleton's Second Maiden's Tragedy (also referred to as 
The Lady's Tragedy). Unlike the ghosts of Old Hamlet and Andrugio, the ghosts featured in Chapman's and Middleton's plays are significant as visual manifestations of memory that recall not paternal relationships, but amorous ones. The emotional memories attached to these relationships create psychological conflicts in Clermont and Govanius based on their desires to act in ways that complicate their masculine gender identities. The ghost of the Duke of Guise in Chapman's play makes a brief and silent appearance, but its psychological impact on Clermont is profound, not only in influencing the extreme action he undertakes by committing suicide, but more significantly, by revealing the emotional nature of the relationship the two men share-one that supersedes fraternal obligation and suggests a kindred spirituality that resembles the unconditional dedication of romantic lovers. The Lady's ghost in Middleton's tragedy recalls for Govanius not only the love they shared when the Lady was living, but, more potently, his failure to perform his duty as the masculine protector against the Tyrant who threatened her honour. The ghost, simultaneously the memorial manifestation of the Lady who was herself characterized in terms of conventionally masculine rationality, highlights Govanius' failure to embody the masculine ideal, while nonetheless rekindling his immense emotional attachment to her, to the extent that he desires to forsake his political duties so that he might reunite with her in death. Both the ghosts of the Guise and the Lady serve primarily to recall the duty Clermont and Govanius owe - revenge for a murdered friend and a defiled lover. Yet, they also unearth intimate memories of amorous connection which drive the male characters to immediately leave off their obligations once fulfilled, and to express a desire to reunite with loved ones in death, regardless of the responsibilities they might leave behind in doing so. This emotional drive of the male protagonists reconceptualises what it means to be a man-capable of participating in patriarchal systems of revenge, while demonstrating an emotional depth and desire for intimate 
connection which straddles traditional gender lines, revealing the potential for a more full human experience outside the constraints of what may be accepted as strictly masculine or feminine behaviour.

The third chapter, "Devils and the Dissolution of Identity", analyzes the influence of the devil Mephistopheles in Christopher Marlowe's Doctor Faustus and the succubus in Middleton's A Mad World, My Masters. Both playwrights portray their devil characters largely in accordance with traditional theological doctrine, as Mephistopheles and the succubus operate through temptation, particularly as they attempt to manipulate sensual stimuli to lead Faustus and Penitent towards sin. However, in both plays, the presence of the devil sabotages the belief systems in which they are inherently rooted, as the psychological disturbance they engender in the human characters results in a rejection of those systems. In Marlowe's play, Faustus seeks a contract with the devils in order to augment his power over the natural world. However, the more reliant he becomes on the devils, the less confident he becomes in his own abilities to procure the kind of knowledge he might have without ever risking damnation — what I term intellectual despair. His reliance on the devils, who manipulate his mind through sensual displays, results in a psychological surrender whereby Faustus exchanges his intellectual criticism and rational perception of the natural world for an obsession with the fate of his soul. Through this obsession with the afterlife, whether salvation or damnation, Marlowe's play links the demonic and the divine as parallel causes of psychological distress because of the theological burden and simultaneous insistence on the fate of the soul—or, what is essentially spiritual unknowing. In the end, Faustus pleads not to God or Lucifer for his soul, but to return to the natural world - the subject of his study which once provided him with a certainty and mastery of knowledge that theological systems of belief deny him. Rather than drive Faustus towards the light of God, the 
influence of the devil—nonetheless an agent of theological doctrine_-leads Faustus to abandon the desire for theological association, whether divine or demonic, in favour of privileging a natural world and earthly study which proves to be a true and reliable source of knowledge, unburdened by the kind of psychological destabilization that comes with the uncertainty of the afterlife.

Similarly, Middleton's succubus functions by embodying its dual connotations, both devil and woman, and indeed, woman as devilish. But while its portrayal seems to reaffirm stereotypes of lusty and morally corrupt women, tropes which Penitent himself spouts only lines before his supernatural encounter, the succubus has a surprisingly contradictory influence on Penitent's thinking. By virtue of being the epitome of a devilish temptress, the succubus ironically causes Penitent to reconsider that view of women, particularly of Mistress Harebrain whom he readily blamed for their affair. Instead, the encounter allows Penitent to recognize both the succubus and the stereotype it manifests for what they are-false deceivers. The result is that Penitent rejects conventional views of female hypersexuality and promiscuity, and reflects on the roles men play in projecting this stereotype onto them as a way to suppress, and so displace, their own sexual appetites. The succubus, then, inverts its own role as a supposed ambassador of a negative gender stereotype by suggesting the need to re-evaluate the validity of such ideas surrounding typical, and expected, male and female conduct.

The final chapter, "Early Modern Manhood and the Making of a Witch", uses the witch figures in Shakespeare's Macbeth and Thomas Goffe's Tragedy of Orestes to investigate how patriarchal codes of power and honour are imbued with expectations of violence and aggression. Such 'masculine' behaviours drive men seeking to adhere to these prescribed codes to actions resembling those of a witch, who becomes ostracized from society as a way for male authorities 
to displace their own questionable behaviours onto a scapegoat. Both the Weird Sisters and Canidia influence their respective titular characters by using their skill in prophecy and necromancy to encourage Macbeth and Orestes to pursue thoughts that have already been preoccupying their subconscious minds - both involving murder. Macbeth murders Duncan in order to obtain the kingship he feels he merits, and Orestes murders his mother and her lover as vengeance for their conspired killing of his father. However, as the witches' influence allows the male protagonists to justify their actions as adhering to a kind of truth, which they look to the witches to provide, it becomes evident that the pursuit of violence is not a matter of the witches' effect - rather, it is an inherent aspect of patriarchal codes which seem to condone the cyclical bloodshed of revenge and war for its continued preservation and operation. While the witches appear to be the powers which drive Macbeth and Orestes into violent madness, by virtue of being figures accused of excessive cruelty and acts like revenge, the subconscious desires they unearth in the human characters they encounter demonstrate that the violence and bloodshed Macbeth and Orestes exhibit are not supernatural. Rather, they are ingrained in the systematic operations of the patriarchal culture which promotes such aggressive displays by tying them to conceptions of ideal manhood. Though the witch might be condemned for her violence, and the war hero praised for his, Shakespeare and Goffe's portrayals of the relationship between the witch and the male seeking his place in the patriarchal structure-whether at its head or as a filial avenger worthy of inheritance - suggests that the two are but points on a spectrum. Moreover, the links the plays establish between man and witch provide commentary on the dangers of social and political expectations which drive men to defy acceptable standards of morality and humanity, to the point that they become the threat to societal stability which must be pursued and expunged 
In the chapters that follow, I seek to demonstrate that the ghost, the devil, and the witch are prominent figures in early modern drama because playwrights are able to use their significant theological and philosophical connection to conceptions of the workings of the human mind to re-evaluate aspects of the dominant belief systems in which both participate, from within those systems themselves. My aim is not to provide a comprehensive study of the various functions of supernatural characters in early modern plays_-such a task would require a much larger project, given the volume of such characters featured in works written and performed in England between 1558 and 1625 alone. However, using a small but diverse sample of plays from the Elizabethan and Jacobean periods, I demonstrate that supernatural characters, where otherwise dismissed as critically insignificant or mechanical in their dramatic roles, can produce a psychological disturbance through which characters might discover the need for critical questioning and doubt in the process of belief formation. 


\section{Chapter One Paternal Ghosts and the Psychological Burden of Filial Obligation}

\subsection{The Ghost in Early Modern England}

In 1564, Bishop Pilkington of Durham told Archbishop Matthew Parker a strange tale about a man in his parish who claimed to have recently spoken with his neighbour, despite the fact that said neighbour had died four years prior. The man, however, was known around the town as a "fantastical raving lunatic", so his story was dismissed as the illusion of a madmanthat is, until the dead neighbour was also seen by the local curate and the schoolmaster.

Nonetheless, the account of the apparition did not spur any overwhelming reactions among the townspeople. The bishop explained such an underwhelming response to so strange an encounter by admitting to Parker that "these things be so common here, and none of authority that will gainsay it, but rather believe and confirm it, that everyone believes it. If I had known how to examine it with authority, I would have done it" (222).

The bishop's account is significant for two reasons. First, the fact that he feels unable to “examine it with authority" speaks to the limited experience he may have had with, presumably, authentic ghosts, especially as the Church of England dissuaded belief in ghosts because of the high potential for demonic deception. In his commentary on the twenty-second article of the Church of England's Thirty-Nine Articles, Scottish Episcopalian bishop Gilbert Burnet warned people against being deceived by "pretended Apparitions" claiming to be the souls of loved ones resigned to Purgatory (217). While Burnet does not explicitly deny the possibility of the existence of ghosts proper, he does caution his followers away from such belief, particularly where it states, "we do also know that it was part of Heathenish Idolatry to Invocate either Demons or departed Men, whom they considered as good Beings subordinate to the Divine essence, and imployed by God in the Government of the World" (247). Burnet's published his 
commentary near the very end of the seventeenth-century, so his thinking would have inevitably differed from the Church of England authorities who wrote the Articles in $1562 .{ }^{19}$

Nonetheless, Burnet's discourse reflects the overall Protestant assertion that any such apparitions were most likely tricks of the devil to deceive true believers. Such is evident in documents written throughout the seventeenth-century; for example, not long after the Church of England published its Articles, Puritan William Fulke wrote his "answere of a Christian Protestant to the proud challenge of a popish Catholicke" (1577) in which he claims that raising the spirits of the dead were "rare \& meruelous workes of God though they follow not the common order of nature" (162); however, it happens so rarely that even the spirit of Samuel which appeared to Saul "which was raised by [a] witche... was the spirite of the Deuvill him selfe" (164). In his scathing 1610 rebuttal to the Catholic Robert Parsons' "particular falsifications of principall Romanists", Thomas Morton, a "staunch Calvinist" and Protestant cleric (Carrafiello 476), scolds Parsons and his fellow papists for their belief in "Deceitfull Apparitions of the dead; and the seales of their superstitions, their false Miracles" (111). It becomes evident then, that prominent Protestants from varying sects of the faith across the sixteenth and seventeenth centuries invoke caution in trafficking with the dead, eliciting skepticism that such apparitions can truly be forces of good, sent by God for beneficial purpose. However, despite the warnings against investing in the possibilities of ghosts, the bishop's account makes evident that as encounters with the dead persisted into Elizabethan, Jacobean, and even Caroline England, belief in the possibilities of ghosts became more difficult to avoid.

Secondly, the bishop's final remark reflects a problem with contemporary records of ghost sightings — namely, that the authors of the accounts generally avoid critically examining

\footnotetext{
19 The Articles cited in the bibliography is not the 1562 version, but a republished copy from 1630, for the reason that the full text of the original could not be found among the Early Records online.
} 
the nature and effect of the apparitions. Instead, these accounts tend to treat ghost sightings as fabrications, or to manipulate their retelling for didactic purposes. This approach allowed authors to relay ghost stories to the wider public while nonetheless adhering to accepted institutional beliefs. In so doing, recorded accounts of ghost encounters like the battle of Edge-Hill and the story of a dead gentleman's spirit appearing to his fraudulent executor, which I will examine later in the chapter, follow several philosophers and religious scholars whose treatises, which were widely circulated in sixteenth and seventeenth-century England, reflect Protestant warnings against being deceived by potentially devilish apparitions. But this means that these pamphlets overlook the psychological impact the encounter with the ghost has on those to whom it appears, as well as its intimate connection to the realm of the mind. In the chapter that follows, I argue that the very ontology of the ghost espoused its psychological significance; as a person's rational soul, the ghost was a person's intellectual essence — a manifestation of the mind itself. To view the early modern ghost through a religious lens only is to misunderstand its psychological significance. Renaissance drama, thus, becomes a necessary medium for the study of contemporary ghost belief, as it extends its exploration of ghosts into both the moral and psychological realms.

Among the most prominent authorities on ghost belief in the period was Anglican minister John Northbrooke. In 1571, John Northbrooke published Spiritus est vicarius Christi in terra, where he writes "against apparitions and appearing of souls after they depart from the body" (121). Northbrooke relies on Scripture to substantiate his position. He cites Psalm 30, which reads "the days of man are as grasse: as a flower of the fielde, so flourish ye / For the winde goeth over it, and it is gone: and the place thereof shall knowe it no more" (122). Of the episode where the spirit of Samuel appears to Saul, which Catholics cited to verify the possibility 
of apparitions appearing to the living, Northbrooke claims that rather than being the actual soul of the dead Saul, the spirit was "not the soule of Samuel but the Devell, which appeared in Samuel's lykenesse" (123). ${ }^{20}$ Northbrooke's work appears just a few years after one of the most well-known treatises on the nature of ghosts and apparitions to come out of the sixteenthcentury: Swiss theologian Ludwig Lavater's De Spectris, first published in 1570, but translated into English in 1596 by Robert Harrison—whose separatist views would have likely made him, and his work, unpopular to Elizabethan scholars. Nonetheless, Lavater's influence on Northbrooke is clear, particularly as Lavater, too, discredits the Samuel-Saul episode as demonic illusion. Lavater argues for the existence of apparitions, but denies the existence of ghostsapparitions being images of spirits produced by the devil, which could not be the veritable souls of men, unless specifically sent by God for didactic purpose (176).

Lavater's apparent uncertainty about the possibility about the existence of ghosts, claiming that they can appear through God, but also denying that He ever sends souls back to Earth (172), reflects the contradictory discourse around ghosts which circulated throughout Europe and England in the sixteenth-century. Furthermore, this uncertainty was prevalent in the works of scholars from various factions of the Protestant faith. For example, like Lavater's English translator Harrison and William Fulke, discussed above, Richard Baxter was of a more Puritan faith than the Anglican Northbrooke. Yet, in his 1691 treatise The Certainty of the World of Spirits Fully Evinced, Baxter more closely aligns himself with an overall Protestant skepticism about apparitions by touting the synonymity between devilish spirits and ghosts (3-4), while

\footnotetext{
${ }^{20}$ Like Northbrooke, Lavater debunks the story of Samuel's ghost, claiming that it was only a demon appearing to Saul in Samuel's likeness. Lavater uses this biblical reference to support his claim that while God could choose to send souls back to Earth, He never does, despite what the Bible (falsely) claims (qtd. in West 48). In his sermon The Shield of our Safetie (1593), Anthony Anderson similarly explains this biblical episode, claiming that the apparition that appears to Saul is but a devil in the likeness of Samuel, not his actual risen spirit (HII).
} 
Harrison interprets Lavater as distinguishing a divine "spirit" (demonic or angelic) from a ghost proper which, if permitted to return to Earth by God, is a human "soul” (194).

While Burnet, Morton, Fulke, Northbrooke, Lavater and Baxter were writing from different Protestant perspectives (from within sects that were often challenging and contradicting one another), and in variant cultural climates, as the theological and political atmospheres in England underwent great change throughout the early modern period, they all nonetheless preach a similar caution against the belief in ghosts. It is also evident that the theological and demonological scholarship on ghosts which circulated in early modern England was primarily concerned with the semantics of ghost belief - not only whether or not it was wise to even consider the possibility that ghosts proper could exist, but how to define the term itself.

Less prominent in these treatises, however, is discussion of the psychological impact of encountering a ghost proper. Of course, Northbrooke, Lavater et al. included the possible spiritual consequences of ceding to an apparition that reveals itself to be an illusion of the devil, but there is little to no material which details how one might be internally, mentally affected by a ghost encounter, especially considering the intimate psychological connection that could exist between a person and the soul of another. For, a ghost, as a human soul, was understood by early moderns to be more than a person's spiritual essence. Instead, the soul was thought to consist of three parts: the sensitive, the vegetative and the rational. Only the rational soul survived after death (M. Edwards 62), so the ghost proper was a manifestation of the rational soul alone, which contained faculties like the imagination, reason, will and memory (Vidal 70). ${ }^{21}$ Unlike spirits, which were merely vessels for divine or devilish communication, ghosts

\footnotetext{
${ }^{21}$ While sensory memory was stored in the sensitive soul, so should logically be expected to cease with the body, as the sensitive soul did, scholars agreed that the sensitive memory would have eventually passed into the long-term memory through the imagination, so even aspects of sensitive memory could be retained in the memorial faculties of the rational soul (Watson 184; Gowland 92).
} 
manifested a person's spiritual and rational essence. The ghost, therefore, possessed qualities that the devilish spirit in the likeness of a person could not - the memory of the person when he/she lived, for example. A ghost retained the entire store of a person's memory, including basic facts about a person's time on earth and recollections of emotional attachments, i.e. feelings associated with particular places or people. While a spirit sent by the devil might appeal to a person's immoral desires, a ghost could access a person's very humanity by recalling personal and intimate memories shared when the soul inhabited a living body. Indeed, the power of the ghost lies in its ability to affect the people to whom it appears by invoking such shared memories in order to establish communication, if not a basis of trust. Why else would the man in the bishop's account have taken the time to speak to the ghost of his neighbour, rather than run away in fear of the devil? It is possible that the familiar likeness of his neighbour warmed the man to the ghost when he would otherwise have been afraid.

However, the problem is that the brevity of Parker's record provides little information about the encounter itself. What exactly did the ghost say to its former neighbour? Did it, perhaps, use familiar phrases, or bring up a particular past occurrence, to persuade the witness of its honesty? These details would help us to further explore the nature of how ghosts operate, but such details are precisely what sixteenth-century records, like that of Matthew Parker, lack. Furthermore, the reigning religious denial of the existence of ghosts made it so that the intricacies of a ghost's affect or influence on the person who encountered it were largely disregarded as the workings of the devil. As Bishop Pilkington implies in his statement, part of this dismissal stems from an inability to critically examine ghost encounters, both because of Protestant skepticism, and because philosophers and theologians of the day could not agree on the most effective criteria for distinguishing a veritable ghost from a devilish (or even a good) 
spirit. ${ }^{22}$ The result is that all such encounters are univocally catalogued as illusions of the devil, which prevents both early modern and modern scholars alike from critically exploring the affective potential of the ghost to the fullest extent. Instead, scholars of sixteenth-century ghostbelief must rely on alternative mediums to ascertain the significance of the ghost during the English Renaissance, which is exactly the task I aim to undertake in the following two chapters, through the use of early modern drama. This first chapter analyzes the ghost encounters and the psychological aftereffects of those encounters on the eponymous protagonists in William Shakespeare's Hamlet and John Marston's Antonio's Revenge. While the plots are similar, the nature of each son's encounter with the ghost of his dead father varies in style, language and significance. However, it is my contention that these plays provide insightful perspectives on the power of the ghost to affect through empathic and ancestral memory and, more significantly, how that affect can rupture a character's psychology to the point of destabilizing prominent notions of belief.

\subsection{The Ghost in Early Modern Drama}

Between 1560 and 1610, fifty-one ghosts proper (i.e. human souls returned to earth) were featured in twenty-six plays (Marshall 257). These ghosts vary in their roles, their degree of influence over other characters, and their origin. Some, like Ben Jonson's Scylla, is notably Senecan, delivering the prologue and setting the scene for Catiline. There are also those that are more distinctly moral, representing an aspect of a character's conscience which weighs

\footnotetext{
${ }^{22}$ Scholars like Lavater, Le Loyer, et al. used rather arbitrary criteria to distinguish good from bad spirits. For example, Lavater differentiates between good spirits - "forewarnings of God [...] that we might understand that all these things happen not by adventure without the will and pleasure of God" (164) — and bad spirits, which are but "vain persuasions" of the devil who seeks to "plant superstition" in the hearts of men (165). Taillepied, in A Treatise of Ghosts, 1588. Taillepied outlines specific criteria for differentiating an evil spirit from a good spirit. For example, evil spirits will flatter and cajole people, while good spirits will speak the Word of God; evil spirits have harsh and loud voices, while good spirits will sound musical (qtd. in Finucane 101). He also claimed that good spirits, who spoke in accordance with the truth of God, would appear as lambs, doves, or men dressed in white, while demon spirits came as lions, bears, black dogs, serpents and toads, and spoke counter to the Catholic faith (Finucane 101).
} 
particularly heavy — among which are the ghosts of Banquo in Macbeth, and Alonzo in The Changeling. Perhaps the most common stage ghost is the spirit of revenge, where the ghost of a murder victim returns to summon a loved one to avenge his/her wrongful death; this occurs in William Sampson's The Vow-Breaker, and, most famously, in Shakespeare's Hamlet. In Sampson's play, the ghost of a scorned lover returns to his beloved, and haunts her to the point of madness and suicide. However, the beloved, Anne, undergoes an intriguing psychological journey as she wrestles with the reality of the apparition and with her own guilt. The change in her speech before, during, and after the encounter with the ghost exposes her characteristic selfindulgence, as her psychology evolves from self-assurance to utter helplessness. I examine the process of this psychological evolution in Hamlet and Antonio, focusing particularly on how their encounters with the ghosts of their fathers cause them to question conventional beliefs and expectations of their socio-political spheres. In so doing, I aim to demonstrate how dramatic ghost encounters create a space for critical evaluation and understanding of the human mind and the nature of belief which some contemporary accounts of ghost encounters prevent.

I believe that part of the reason the contemporary records I explore in this chapter, and others like them, are unable to delve into ghosts' potential for insight about human psychology is because such accounts confine themselves within the bounds of prominent religious doctrine. As will become evident in the latter two sections of the chapter, some authors of sixteenth and seventeenth-century retellings of ghost encounters had a tendency to frame their discourse within a larger didactic scheme. As such, the actual details of these ghost encounters are often eclipsed by the author's intended moral. The result is that the figure of the ghost is kept strictly bound by conventional Protestant views. However, by confining themselves within the limits of systematic 
belief, the authors retelling these non-literary encounters fail to account for the fact that ghosts were both a religious and a psychological phenomenon.

Arguably the most psychologically analyzed of all early modern plays, Shakespeare's Hamlet is the prime example of the mental turmoil that results from interactions with the dead. Numerous literary, psychoanalytic, cultural and historical scholars have attempted to decipher the perplexing psyche of the Danish prince; namely, why he hesitates to kill his uncle, and, consequently, fulfill the ghost's call for revenge. Many critics have conceived of this hesitancy in terms of mental disorders. Peter Bruce Waldeck claims that Hamlet's delay in acting on his duty stems from his anxiety about preparing for his revenge task (154). Stephen A. Reid and James Foster Palmer discuss Hamlet's psychological nature in terms of melancholy, though with somewhat contrary opinions. Reid argues that Hamlet first becomes melancholy between the first and second acts (384), following his conversation with the ghost, whereas Palmer suggests that Hamlet becomes increasingly less melancholy as the play progresses, and that his hesitancy is actually a sign of reason returning to temper his passionate psychology (402).

For Palmer, Hamlet's refusal to murder Claudius at prayer is emblematic of this return to reason, as his concern with morality demonstrates the resurrection of conscience where emotional self-destruction, as evident in his infamous soliloquy, previously ruled (404). Ernest Jones, too, picks up on Hamlet's moral self-deprecation. Jones argues that the many excuses Hamlet makes for his inability to act on his father's behalf "unequivocally points to a tortured conscience" (89). For Jones, this "tortured conscience" stems from an oedipal lust for his own mother, and the subsequent guilt of always having wished his father dead (93). Because of this, Jones implies that the ghost's reminder to "Remember me" (I.v.91,) invites a psycho-analytic struggle that is steeped in morality; it is both Hamlet's guilt and his fear of his own incestuous 
feelings which hinder him from performing his duty. Both Palmer and Jones identify the intricate connection between Hamlet's complicated psychology and the moral issues with which he must contend. But, Palmer views Hamlet's psychological journey as one that eventually leads him back to the moral path - indicated by the fact that Hamlet begins to consider the matter of conscience, and the moral implications of revenge. Jones, on the other hand, observes a decline in Hamlet's concern with morality as the combat between desire, revenge and conscience gradually destabilizes his internal beliefs, to the extent that all three become void of their conventional significance (an observation upon which I will elaborate in my own analysis of the play). Regardless of their differing claims, both scholars highlight that Hamlet's psychological conflict is a moral conflict, and the ghost is at the centre of both. The play's concurrent concern with psychology and morality places the ghost in a role with which Shakespeare's audience would be familiar: as an undecipherable spiritual agent whose plea for revenge forces characters to consider the moral and political implications of action in a world where conscience is key.

Unlike in Shakespeare's Hamlet, Antonio's Revenge has been largely discredited by early modern scholars because of its break with genre conventions, particularly where morality is concerned. Marston's revenger does not suffer for his own brutal crimes; rather, he is praised by the Venetian state, offered political advancement, and eventually allowed to pursue a quiet, penitent existence. For several scholars, this subdued conclusion is highly problematic. Allister Irwin MacDonald argues that the ending presents "a moral difficulty" because "the revengers apparently are not to be looked at as having committed any crime, even though, Antonio has butchered Piero's young son...the Senators of Venice thank them for ridding the state of a bloody tyrant" (123). Similarly, Fredson Bowers observes that "by every English tenet, Antonio is a cruel and bloodthirsty villain who has overstepped the bounds of revenge. Yet, by Marston's 
Senecan morality, Antonio is a dutiful son, sacrificing the blood of the murderer's kindred to appease the ghost of his slain father, and he remains a hero at the end" (qtd. in MacDonald 125). MacDonald, however, disputes Bowers' Senecan reference, claiming instead that "Seneca would have deplored this response, which is not 'rational' revenge free from passion" (125). The result of Antonio's lack of Senecan reason is that scholars question whether morality factors into his decisions at all. Phoebe Spinrad notes that, even at the end of the play, "Antonio and his friends never speak of their sins, but only of their sorrows" (172, emphasis mine). Their passions dominate their thoughts and actions even unto the last act, but Spinrad segregates those feelings from their moral compass, claiming that the play never suggests that their suffering has morally or spiritually cleansed the conspirators $(173) .{ }^{23}$

However, Spinrad identifies an important element of Antonio’s psyche, which both Bowers and MacDonald overlook in their somewhat narrow assessment of his character. She insightfully notes that in Marston's play, Antonio "reverts to his own father's will" (178), as the ghost of Andrugio infuses the spirit of revenge into his son. By replacing God's authority with the rule of the earthly father, I argue that the play distorts conventional expectations of morality. James Alsop agrees that Marston leads his audience into "moral uncertainty" because he places Antonio's Revenge "outside the bounds of moral and narrative conventions" (227)—which, according to Jonathan Dollimore, makes Marston’s play a true radical tragedy (204). Furthermore, the ongoing brutality minimizes the impact of any shows of virtue that the play does exhibit, especially as the pure and gentle Mellida dies, and even the once-rational

\footnotetext{
${ }^{23}$ Like Spinrad, Elaine and Charles Hallett observe that the ending fails because Marston "never endows Pandulpho or Antonio with the spirits of humility and repentance which would have made their retirement an acceptable alternative to suicide" (385). Instead, the Halletts argue that Marston makes it seem as though the suffering endured by the conspirators has been enough to cleanse them of their sins (385), even as the play draws numerous parallels between the violent acts of Antonio and Piero, but only the latter dies.
} 
Pandulpho eventually succumbs to his internal passions (Baines 288). Rather than espouse a lesson that accords with sixteenth-century morality, Marston privileges the conflicted psychology of his protagonist, for whom concepts of good and right are blurred by the influence of the spirit of his father. By labelling Antonio a "bloodthirsty villain" who is "out of control", scholars like Bowers and MacDonald take the character's psychological depth for granted, and in so doing, they overlook the potential of the ghost — a fairly conventional dramatic figure that exists within the religious ideology — to uproot traditional beliefs about the place of morality in the world.

Even as the ghost invokes the psychological struggle which, I believe, becomes one of the principal conflicts in the play, Charles and Elaine Hallett are quick to claim that the nature of the ghost, partially because of its influence on Antonio, is one of the reasons Marston's play fails. They claim that Marston sabotages the drama by assigning the ghost dual function: both a representative of Providence and the classical spirit of Revenge. However, by serving this dual function, the Ghost of Andrugio acutely represents the competing forces on the play's larger scale. For, as the play's critics imply, Marston's audience would have expected the play to ascribe to certain genre-specific characteristics, one of which is that the wrong-doer will have to pay moral recompense. As a revenge tragedy, Marston's play is already inscribed into a system of moral convention which the ghost, if indeed it does act as a spiritual representation of God's authority, is expected to uphold. However, those institutional religious beliefs about what is means to be moral get requalified in the play, so the ghost as a traditional representation of Providence, or God's will, cannot stand. Instead, the ghost counters convention with the spirit of Revenge, which, though a dramatic convention in itself, is the presence that allows Antonio to engage with his own psychology, his own thoughts and desires. The result of this focus on the 
individual is that concepts of good and right come to reflect not the will of God the Father, but of his concerns for the spirit of his earthly father, Andrugio.

Yet, because "the ghost is...too closely associated with the excesses of revenge", the Halletts believe that the audience cannot accept the classical ghost in a Christian role (382). However, the play itself does not necessarily purport that the ghost's dominant purpose is a Christian one. Rather, it is Antonio who links the ghost to Providence; he rejoices "o boundless heaven" (III.iii.6) when the opportunity presents itself to kill Julio. As the ghost re-enters in the final Act to witness Piero's murder, again Antonio claims "I taste the joys of heaven" (V.v.35). If the ghost's supposedly Christian purpose seems out of place, it is because Antonio has reconfigured moral convention to accommodate his revenge task. He does this by linking his father's ghost to Heaven, and so justifies his violence as right and just. The Ghost of Andrugio, therefore, does not represent the play's failure to persuade its audience of, what Spinrad calls, the "sacralisation of revenge"24; instead, the ghost refocuses the audience's attention towards the psychological life of the protagonist, and his attempt to navigate competing desires and impulses in a world where conventional systems of morality hold increasingly less sway.

In the sections that follow, I provide a detailed analysis of the psychological impacts the paternal ghosts in both Hamlet and Antonio's Revenge have on their sons. I will look at how the spiritual and rational ontology of the ghosts contribute to their pervasive influence throughout Shakespeare's and Marston's plays. Specifically, I examine how the fathers' post-mortem existence actually augments their paternal power and authority over their sons, to the point that

\footnotetext{
${ }^{24}$ In her article, "The Sacralisation of Revenge in Antonio's Revenge", Spinrad argues that the play "rallies" for a religious justification for revenge, and in doing so attempts to provide an explanation for why Antonio is not only praised for his bloody deeds, but allowed to retreat unscathed and unpunished into a quiet life. She argues that Marston's drama alludes to biblical stories at several moments; for example, she notes how Julio's submission to death mirrors that of Isaac, whose sacrifice was demanded by God Himself (175).
} 
both Hamlet and Antonio become so focused on their filial obligation, that the moral, social and political consequences that result from their attempts to adhere to conventional ideas of family honour and duty challenge the validity of the very ideals they strive to uphold. These playwrights use the figure of the ghost to undermine the authoritative dictate of the very same religious and political systems of which it is part, inscribed in codes of morality and patrilinearity which dramatic ghosts then critique from within. By comparing the role of the ghosts in contemporary seventeenth-century pamphlets to those of Old Hamlet and Andrugio, the following literary analyses aims to emphasize the dramatic potential of the ghost as a catalyst for psychological resistance against traditional patriarchal values which may do more harm than good.

\subsection{The Ghost of Old Hamlet}

On Christmas Eve 1641, in the town of Edge-Hill, Warwickshire, ${ }^{25}$ several men "of the most credit" encountered the "apparitions [of] two jarring and contrary Armies"—one dressed in the King's colours, and the other wearing Parliament's. ${ }^{26}$ The ghost armies appeared between twelve and one o'clock in the morning of the twenty-fourth, but they were not immediately visible to the local onlookers, as "first [came] the sound of Drums a far off, and the noyse of Soulders, as it were, giving out their last groanes." From the distant sounds alone, the witnesses were "much amazed, and amazed stood still." But as the noise drew increasingly nearer, "too much affrighted, they [the onlookers] fought to withdraw as fast as possibly they could, but then, on the sudden, while they were in these cogitations" the ghosts of soldiers became visible on the

\footnotetext{
${ }^{25}$ Edge-Hill is a Civil War battle site. The Battle of Edge-Hill was one of the first battles of the English Civil War, and took place on October 23, 1641, just months before the recorded ghost encounter. It was a key victory for the Parliamentarians, who were able to delay Charles I's journey to London (www.britannica.com).

${ }^{26}$ This account comes from a pamphlet, published anonymously in January 1641, A Great vvonder in heaven shewing the late apparitions and prodigious noyses of war and battels seen on Edge-Hill neere Keinton in Northampton-shire : certified under the hands of William Wood Esquire and iustice for the peace in the said countie, Samuel Marshall preacher of Gods Word in Keinton and other persons of qualitie, Wing / G1787, EEBO.
} 
field before them. The soldiers were "incorporeall" and came "with Ensignes displayed, Drums beating, Musquets going off, Cannons discharged [and] Horses neighing." The two armies clashed, and the fighting went on until two or three o'clock. While they witnessed this spectacle, the onlookers claimed that "they could not believe they [themselves] were mortall, or give credit to their ears and eyes... runne away they durst not for feare of being made a prey to these infernall souldiers, and so they with much feare and affright, stayed to behold." After a few hours, the ghosts of the King's men were forced to retreat, and following a brief celebration, the Parliamentary troops, too, "with all their Drummes, Trumpets, Ordance and Souldiers vanished." The onlookers recalled being "glad they were gone, that had so long staid them...against their will." Nonetheless, the witnesses returned to the site the following night, December twenty-fifth, with local officials in order to corroborate what they had seen. The ghost armies came again, and all of the witnesses, townsperson and official alike, "terrified with these visions of horror, withdrew themselves to their homes, beseeching God to defend them from these hellish and prodigious enemies." Their strange report eventually reached King Charles I, who sent a few of his trusted captains to Edge-Hill to observe the phenomenon. When these captains beheld the ghosts, they "distinctly kn[ew] divers of the apparitions or incorporeall substances by their faces, as that of Sir Edmund Varney, and others that there were slaine."

The account ends rather abruptly, with the addition of a concluding line wherein the author attempts to explain away the strange encounter as a warning against the ongoing conflict between royalists and parliamentarians: "What does this [the apparitions] portend, God only knoweth, and time perhaps will discover; but doubtlessly it is a signe of his wrath against this Land, for these civill wars, which He in his good time finish, and send sudden peace between his Maiestie and Parliament" (7). It may be that the actual details of the apparitions themselves were 
quickly dismissed without examination because the final political moral, and not the nature of the apparitions, was the primary focus of the pamphlet. But it is intriguing to note that the few details the author does note about the images of soldiers echo conventional tropes associated with sixteenth and seventeenth-century ghost encounters. These tropes also informed many dramatic depictions of onstage apparitions, so it is unsurprising that the Edge-Hill encounter shares elements in common with the appearance of Old Hamlet's ghost in Shakespeare's play. For example, both the ghosts of the soldiers and Old Hamlet's ghost appear around midnight, ${ }^{27}$ which was known as the peak time for such supernatural activity to occur. ${ }^{28}$ In the case of Hamlet specifically, the dramatic ghost also shares aesthetic similarities with the Edge-Hill ghosts, as both appear in military garb — the soldiers being ready for battle, and Old Hamlet being known for his military strength. ${ }^{29}$ The immediate effects of the apparitions on the witnesses are also similar. In the 1641 encounter, the townspeople recalled being "too much affrighted" to run; upon seeing the ghost of his father, Hamlet recognizes the apparition's ability to "horridly...shake our disposition" (I.iv.34). In both cases, the appearance of the ghost invites the kind of paralysing fear that one would expect from encountering the supernatural.

The 1641 record, however, does not critically consider the influence of the ghosts; rather than question the extent to which the apparitions shocked and/or upset the mindsets of the local onlookers, the author attempts, and fails, to use standard morality to curb any such intellectual inquiry. Prior to launching into the Edge-Hill account, the pamphlet's author presumes that the

\footnotetext{
${ }^{27}$ At the beginning of I.i, Barnardo confirms, "'tis now struck twelve" (7).

${ }^{28}$ See Thomas Nashe's Terrors of the Night (1594).

${ }^{29}$ The stage directions on p. 145 state that the ghost appears "clad in completed armour, with its visor raised and a truncheon in its hand". When the ghost vanishes temporarily, Horatio explains to Barnardo and Marcellus how Old Hamlet fought and defeated Old Fortinbras and so annexed the Norwegian's lands. It is because of this action that the men are on guard every night, as they anticipate the revenge of young Fortinbras to take back what Old Hamlet claimed from his father (I.i.79-109).
} 
apparitions in the oncoming tale should be taken for devils, not the souls of men: "divels appeare either in premonstrance of Gods Judgement, or as fatall Embassadours to declare the message of mortality and destruction to offending Nations" (4). The author suggests that the appearance of soldiers from the past foreshadows the pending death and destruction that recur the longer the country remains at war, and by so doing, trespasses God's will for peace among His people. But while he focuses on the apparitions as representations of futurity, I would suggest that the ghosts of the soldiers are not only shadows of foretelling; they are figures of memory, figuratively and literally. Figuratively, they represent the suffering they re-enact, recalling the memory of the battle, but more-so of the human loss sustained from it. Such is telling by the fact that even before the ghosts come into view, the "last groanes" of the injured ring through the night air. But the memory of suffering, of the human consequence of war, does not resonate with the peopleat least, not in the author's framing of the account. Their recorded reactions to the apparitions of soldiers fighting and dying on the field before them stagnate at fear-according to the author's retelling, the witnesses never seem to move past their initial fright to feel empathy, or even pity for the suffering being re-enacted. And rather than critically consider the scene before them, they are described as immediately "beseech[ing] God to defend them from these hellish and prodigious enemies". The use of the word "enemies" coincides with the previous description of "infernall soldiers"; it signifies the automatic assumption that the apparitions must be agents of the devil, a presupposition that results from institutional indoctrination. Why should the onlookers be said to consider the images of soldiers, many of whom were local town and countrymen like themselves, their "enemies" otherwise?

By invoking Protestant skepticism, and assuming that the apparitions are devilish imprints rather than considering the possibility that these could be authentic souls of the dead, 
the onlookers never allow themselves to become invested emotionally or psychologically in the scene - or, if they do, such detail is omitted from the author's account. The result is that the author's version of the onlookers lack empathy and only briefly glance at the suffering of war that should be observed critically. Even the king's men, who recognize the faces of the soldiers as men they fought alongside, do not speak in feeling terms about their fellow comrades. Any human connection, any love between soldiers, is forsaken on the assumption that such apparitions can only be lies. However, the apparitions, taken as veritable ghosts, are not only figurative representations of the memory of the past, but visual manifestations of the soldiers' memorial faculties. Seen through the lens of those who experienced it, the battle becomes more than a site for moralization; rather, the recognition of the presence of the souls of men revisiting the battlefield upon which they have already died brings the war into an individual, psychological focus. The faces of the men, like Edmund Varney, may not be masks of the devil, but manifestations of the internal, spiritual essences of real men. And just as the king's captains recall their faces, so the ghosts of the soldiers, apparitions of memory, can likely recall theirs, too. There is the potential for a spiritual connection through shared memory that the pamphlet prevents, because its explicit purpose is to promote a particular view on a contemporary war. However, if the captains were able to indulge this connection with the apparitions without the pressure to conform to religious doctrine, it is likely that the emotional toll of human sacrifice would resonate in a way that reflects the reality of war for the individual, the way history rarely recalls.

There are other significant links between the encounters that are not immediately apparent, because the Edge-Hill account tends to proceed too quickly from its most substantial observations, and any potential psychological implications for the observers themselves are 
overlooked completely. Hamlet, however, takes similar observations and extensively unpacks them; by delving into the impact that the ghost encounter has on Hamlet's individual psychology, Shakespeare's play explains not only the psychological, but the larger sociopolitical significance of its ghost in ways that the 1641 account only hints at and then moralizes away. From the very beginning of the pamphlet, the historical account frames its retelling in the institutional beliefs of the time:

"That there hath beene, and ever will be Larua Spectra, and such like apparitions, namely, Ghosts and Goblins, have beene the opinion of all the famoustest Divines of the Primitive Church, and is (though oppugned by Some) the received Doctrine of divers learned men at this day, their opinion being indeed ratified and confirmed by divers Texts of Scripture, as the Divells possessing the Swine" (3).

The author of the pamphlet precedes his account about the sighting of multiple apparitions by aligning himself with Protestant ideas, alluding to the idea that the apparitions must be devils when he refers to them as "those hellish and prodigious enemies" (6). Before the readers get a chance to decide for themselves, the author categorizes the tale he is about to relay as a fiction, an impossible occurrence, thereby limiting the degree of influence it might have over those exposed to it. This kind of bias is something that Shakespeare does not explicitly attempt in Hamlet. It is important to note that Hamlet does consider the potentially devilish nature of the ghost, particularly when he questions whether, "the spirit that I have seen /

May be the devil... / ...yea, and perhaps / Out of my weakness and my melancholy / ... / Abuses me to damn me" (II.ii.588-93). The ghost, itself, however, implies it comes from the fires of Purgatory, ${ }^{30}$ but arguably the ghost of Old Hamlet cannot be labelled as either strictly demonic or purgatorial. It seems genuine in his desire for vengeance, so it sets Hamlet the task of murder not, presumably, to damn him, but neither does it seem concerned with freeing itself from its

\footnotetext{
30 The Ghost tells Hamlet that he is "Doomed for a certain term to walk the night, / And for the day confined to fast in fires, / Till the foul crimes done in my days of nature / Are burned and purged away" (I.v.10-13, emphasis mine).
} 
limbo state by cleansing itself of its own sins; instead, it encourages the son to sin in the name of revenge. The ghost of Old Hamlet, thus, blends several traditions - it is a hybrid of Shakespeare's making. Consequently, this 'combination ghost' does not align with a specific set of beliefs - neither Catholic nor Protestant, not theological or folkloric — and so is not defined by institutional bias, as its significance stems not from his origin, but from his influence on the characters with whom it interacts.

\section{An Infection of Memory}

The power of the ghost to influence through memory is what drives the complex psychological exploration in Hamlet. Like the ghosts of the soldiers in the 1641 encounter, the Ghost of Old Hamlet, treated as a ghost proper, is a spiritual manifestation of the memory of the king when he was living. The ghost's tie to memory is emphasized by the desire to share the memory of the king's death with Hamlet, in order to move to him to action. The ghost's rhetoric is evidently crafted to recruit Hamlet to the purpose of revenge, and the contagious effect of its speech is particularly striking as he recalls the experience of being poisoned:

With the juice of cursed hebenon in a vial, And in the porches of my ears did pour The leperous distilment, whose effect Holds such an enmity wi'th'blood of man That swift as quicksilver it courses through The natural gates and alleys of the body And with a sudden vigour it doth posset And curd, like eager droppings into milk, The thin and wholesome blood. So did it mine; And a most instant tetter barked about, Most lazar-like, with vile and loathsome crust All my smooth body (I.v.62-73).

The ghost of the king describes the effects of the poison to the extent that its words project those effects onto the listener. Sarah Outterson-Murphy notes the similarities between Claudius' poison and the ghost's tale — both enter through the ears, and both have harrowing effects on the 
recipient (127). The specific diction of the ghost's description reflects the spreading movement of the poison throughout Old Hamlet's body. "Leperous distilment" connotes the initial infiltration of disease into the bloodstream, just as the position of this image at the start of the account marks the initial distilment of the ghost's grotesque memory into Hamlet's own head. The consonant repetition of the "s" in "swift as quicksilver...courses... / gates and alleys" mimics the flow of the poison, at the same time as the ghost's words continue to flow and fill up Hamlet's entire being. As the tale flows from the ghost to Hamlet, so the memory of the poisoning transitions from one to the other. It is through this sharing of memory from one rational soul to another that the ghost succeeds in attracting Hamlet to its cause.

Just as Outterson-Murphy suggests that the ghost's words work as a kind of poison, Angus Gowland and Robert Watson observe that early moderns believed ghosts had the ability to "infect" the bodies of others. ${ }^{31}$ Their observations coincide with the idea of fascination, ${ }^{32}$ which Francis Bacon defines in his Advancement of Learning (1605) as "the power and act of Imagination, intensive upon bodies other than the body of the imaginant" (II.46). Logically, it follows that the power of the imagination is reflective of the power of the soul, being that early moderns believed that the imagination was one of the main components of the rational soul. According to several influential philosophers, the power of the ghost - as a soul separated from

\footnotetext{
${ }^{31}$ See Watson's The Rest is Silence: Death as Annihilation in Early Modern England and Gowland's “The Problems with Early Modern Melancholy".

${ }^{32}$ A postulation first put forth by the Arabic philosopher and physician, Avicenna, whose tenth-century work on the soul was translated into Latin and circulated in Western Europe between 1160 and 1310 BCE. Avicenna believed that "the rational soul is pure and immortal...it alone is capable of influencing a foreign body as well as its own body through the power of the imagination" (qtd. in Degen 387). Avicenna's postulation was resurrected in the fifteenth century by Marsilius Ficino, an Italian humanist whose 1482 Platonic Theology likewise asserts "the soul's occult power of inducing contemplative experience in ensouled beings" (Hankins 43). Avicenna and Ficino evidently had an influence on Bacon's definition of fascination in The Advancement of Learning, and the idea continues to infiltrate writings throughout the rest of the seventeenth-century, such as in Johann Christian Fromman's 1675 Tractatus de fascination, 719.f.25, British Library.
} 
the body — to affect the imagination of another would have been especially powerful. For example, Thomas Aquinas ${ }^{33}$ — whose twelfth-century treatise, Summa Theologica, was foundational for many Renaissance ideas about the mind and soul—and Marsilio Ficino — an Avicennean ${ }^{34}$ whose work on the affective soul preceded, and is evidently reflected in Bacon's own - agree that the separated soul was stronger than the soul within the body. ${ }^{35}$ Thus, the affective power of the ghost, by virtue of being a separated soul, would have a larger impact on an ensouled person than one human might have on another.

It is important to note that neither Hamlet nor Hamlet ever make direct references to this contemporary religious and philosophical discourse; furthermore, the ghost does not describe itself using such loaded terms as separated, or even rational, soul. However, at least the elite members of Shakespeare's audience would have been well acquainted with the treatises by Aquinas - whose works continued to serve as an influential source for many early modern beliefs surrounding the soul—and Bacon, whose contemporary influence as a credible scholar was widespread. Therefore, my argument of how the ghost's very ontology allows him to influence Hamlet's (and Antonio's, as we will see in the next section) mental processes is based on an understanding that the ideas about the soul found in sixteenth and seventeenth-century religious, philosophical, and even physiological tracts which inform my analysis were familiar to the early moderns in Shakespeare's audience - if not directly through scholarship, then through

\footnotetext{
${ }^{33}$ Despite his opposition to Avicenna's argument, Aquinas implicitly suggested the affective abilities of the soul in their own works. In his Summa Theologica, Aquinas suggests that whatever the soul operates on, must "ha[ve] a natural aptitude to be united to the soul, and to be by its likeness to the soul" (Q78 A1). Aquinas essentially states that the object the soul acts upon must be related to it; yet, this criterion does not discredit the possibility that the soul can act on another soul, especially as nothing can be closer in likeness to the soul than another soul. Hamlet indicates as much when he questions what the ghost might do to his own soul "being a thing immortal as itself [the ghost]" (I.iv.46).

${ }^{34}$ See previous footnote.

${ }^{35}$ Hankins, Ficino, Avicenna and the Occult Powers of the Rational Soul, pp. 43; Aquinas, Summa Theologica, Question 89, wherein Aquinas claims the superiority of the separated soul's intellectual powers, which early moderns believed resided in the rational soul in the faculties of will, memory and imagination.
} 
the quotidian circulation of such popular concepts. Thus, my claims about the potential of the ghost as a visual manifestation of the rational soul to influence and/or infect the minds of others are rooted in early modern beliefs surrounding the spiritual and rational ontology of the ghost, regardless of whether those discourses are directly referenced in the play itself.

The circulation of these ideas in the time Shakespeare was writing makes it feasible that the ghost could establish a psycho-spiritual connection with Hamlet by virtue of shared memory. However, it is the ghost's dramatic effect first and foremost which makes its psycho-spiritual influence possible. The shock of its appearance uproots the stability of Hamlet's psyche, blurring illusion and reality, and making Hamlet vulnerable to the ghost's affective powers. After Hamlet insists on following the ghost's mysterious, but persistent summons, Horatio fears for his friend because "he waxes desperate with imagination" (I.iv.62). Before Hamlet ever hears the ghost's tale, his desperation to follow the ghost creates a predisposed susceptibility to being influenced, or "infected", by the affective power of the ghost. Moreover, the state of his "imagination" contributes to Hamlet's mental and spiritual vulnerability; if we consider Bacon's definition of fascination, the imagination was the key conduit for spiritual affect. By recounting its memories of the king's death, the ghost transfers its memories to Hamlet by way of the imagination, and such is successfully achieved partly because the shock of the appearance of the ghost has rendered Hamlet's mind unstable, incoherent, and so permeable to any and every version of truth. The ghost earns Hamlet's trust and persuades him of its authenticity when its memories confirm Hamlet's underlying suspicion — upon hearing of his uncle’s murder, Hamlet cries, “O my prophetic soul!" (I.v.40) The spiritual tie between the ghost and Hamlet is strengthened when the connection between their souls is solidified in this moment, as the memory of the ghost becomes an internal truth for Hamlet. 
After hearing the ghost confirm his own previous fears, Hamlet insists to his friends that "it is an honest ghost" (I.v.140), despite having previously considered the possibility of it being a demon sent to delude him: "Be thou a spirit of health or goblin damned, / Bring with thee airs from heaven or blasts from hell, / Be thy intents wicked or charitable..." (I.iv.18-20). His desperate imagination is a product not only of his fear and shock at seeing the ghost, but at the immense desire to believe that it is the soul of his father returned to him. This is evident from Hamlet's first assessment of the apparition, where, despite admitting that it may be a false image come with wicked intentions, he chooses to interpret the "questionable shape" (I.iv.22) as the soul of his father: "I'll call thee Hamlet. / King, father, royal Dane. O answer me!" (23-24) In so doing, Hamlet betrays his desire to believe the ghost before even hearing what he might say, as it is the recognizable shape of the ghost, the likeness of the king, that shatters Hamlet's barriers of critical skepticism. Unlike the account of the king's captains in the 1641 encounter, who explicitly recognize the faces of the ghost soldiers as once-familiar men and still deny the possibility of the return of their souls from the dead, Hamlet's first sight of the face and form of his father produces a desire to believe in the possibility that the souls of the dead might return. While the pamphlet makes its institutional bias obvious through the captains' stoic reaction to the ghosts of fellow soldiers, Shakespeare privileges the individual's internal struggle to make sense of the least comprehensible aspects of human life, as Hamlet's yearning to believe the ghost is a ghost hints at larger contemporary issues with mortality, ${ }^{36}$ and the difficulty of coming to terms with the death of loved ones.

\section{The Psychological Toll of Remembrance}

\footnotetext{
${ }^{36}$ Finucane notes that between the end of the middle ages and the start of the Renaissance, there was an increasing concern with the decay of the physical body, which he cites as another sign of the morbid concern about death. He notes that in response to the fear of physical mortality, people in the $15^{\text {th }}$ and $16^{\text {th }}$ centuries began to focus on ideas about perpetuating memory through continued familial reverence and physical memorial monuments (52).
} 
Hamlet's acceptance of the ghost of his father as such engenders a link between the two that eventually drives the affective bond underpinning the urgency of revenge. Rather than fear the ghost to the point of denial, Hamlet feels empathy for the ghost (Pearlman 82). He makes his sympathy for the ghost's tale increasingly evident, as his periodic outbursts of horror throughout the account reflect the ghost's gradual strengthening influence over Hamlet's mind. Overall, the interruptions are brief and marked by exclamation——Alas poor ghost!" "O God!” "Murder!" “O my prophetic soul! My uncle!"' (I.v.4, 24, 26, 40-41) —which further demonstrate the powerful shock the tale produces in Hamlet. The ghost concretizes its hold over Hamlet the same way it was initiated: through memory. The ghost ends the account with "Remember me" (91), a multistrain imperative, as Hamlet must remember the encounter itself, and all he has heard; he must remember his task, to avenge his father's death; but most importantly, he must remember his father, the debt he owes to him as his son — as the paternal connection, undeterred by death, demands he see his revenge task through. Hamlet takes the command on immediately and with the utmost intensity. After the ghost exits, he embraces his boon enthusiastically, treating his father's word as a "commandment" which "all alone shall live / Within the book and volume of my brain" (I.v.102-103). He chooses to reject all other knowledge previously acquired at Wittenberg — an academic perspective that may have helped to broaden his mind - in order to focus his thoughts only on the matter of revenge. Stephen Greenblatt insightfully observes that Hamlet begins to suffer from "an excess of remembrance" $(218)^{37}$, and this becomes increasingly evident as his psychological burden begins to manifest itself in his physical disarray. It becomes as though Hamlet has internalized the ghost to such a degree that he adopts not only the memory of the ghost, but his very morbid disposition. In the scene following Hamlet's conversation with

\footnotetext{
${ }^{37}$ See also Jean E. Howard's Shakespeare's Ghost Writers: Literature as Uncanny Causality, Routledge, 2010.
} 
the ghost, Ophelia notes a peculiar change in the prince; he comes to her "pale as his shirt, his knees knocking together /... / As if he had been loosed out of hell / To speak of horrors" (II.i.82, 84-85, emphasis mine). Ophelia's description of Hamlet's demeanor is astoundingly similar to the ghost's tale about his own disposition: by "day confined to fast in fires/ ... / I could a tale unfold whose lightest word / Would harrow up thy soul" (I.v.11, 15-16). Almost immediately, Hamlet seems so consumed by the ghost as to appropriate his look and language. His former enthusiasm for his task to remember-through recollection, reverence and revenge-quickly wanes, as Ophelia also mentions that he came to her "unbraced/...fouled/...ungartered"—-signs of physical unkemptness that reflect the disorder of his mind, but which also parallel the ghost's description of its own undoing, "unhouseled, diss-appointed, unaneled" (I.v.77).

Hamlet's aesthetic decline is one minor symptom of larger psychological distress, as the affective power of the ghost to rouse Hamlet to the cause of revenge proves to be mentally and spiritually binding. Hamlet's commitment to revenge holds him to the memory of the ghost and of his father, to the point where Hamlet becomes trapped within his own compulsion to remember. His promise to his father becomes a mental cage from which he cannot escape. From the first lines of his discourse with the ghost, Hamlet ascertains that he is "bound to hear" what it has to say (I.v.6). While Hamlet's being "bound" connote ideas of fate and destiny, the word also signals a kind of servitude which Hamlet must enter into in order to adequately respond to the ghost's demand. In the 1641 encounter, the witnesses recall feeling similarly constricted, as the fear of the ghost scene anchors them where they stand "against their will". The hold of the ghost soldiers over the townspeople, however, is physical, not psychological, as the witnesses seem to give little thought to their fear beyond blaming the wiles of the devil. Hamlet's binding, on the 
other hand, is very much a psychological constriction, the suffocating impact of which he hints at in his conversation with Rosencrantz and Guildenstern.

Despite the moments where Hamlet explicitly puts on his "antic disposition" for his friends, suspecting them to be his uncle's informants, there are, nevertheless, prominent moments in his language that reveal the truth of his psychological struggle. For example, in response to Rosencrantz's claim that the "world's grown honest" (II.ii.236), Hamlet denies the truth of the observation, and his inability to see the world as honest reflects the convolution of his psychological state. For, the word "honest" connotes a kind of transparent simplicity that would negate the very need for the ghost's coming; if indeed the world was honest, Claudius' treachery would be well known and Hamlet, himself, might sit on the throne instead of his scheming uncle. But, knowing the truth of the sordid affair, Hamlet is left haunted by the memory of his father, and is consequently shackled to a promise of vengeance that holds Hamlet's mind under strain. As a result, Hamlet asserts that "Denmark's a prison" (II.ii.243), and though the world has "many confines, wards, and dungeons", Denmark is "one o'th'worst" (II.ii.244-45). But Denmark itself is not confining; instead, it is what Denmark represents, the psychological and spiritual connotations, which imprison Hamlet. He makes as much obvious when he tells his friends, "I could be bounded in a nutshell and consider myself a king of infinite space, were it not that I have bad dreams" (II.ii.250-254). It is not the physical space that concerns Hamlet, but the psychological distress that comes from such space. His "bad dreams" reveal the true source of his conflicted mind. According to Hamlet, "a dream is but a shadow" (258), which Rosencrantz then describes as "airy and light" (259). His internal distress is, therefore, caused by airy shadows, which mentally confine him to the point where even a nutshell would seem less claustrophobic. Could a ghost not be considered the semblance of a 
shadow, being a visual manifestation of a person's likeness without corporeal form? For, the persistence of the shadow of his father, tied to the place of his death, haunts Hamlet, and the call to revenge the ghost insists upon distresses him to the point where his duty is all that surrounds him, and the rest of the world he knows closes in around the task he has been given. The ghost of his father is symbolically connected to Denmark as well. As a shadow in the likeness of the king, the ghost embodies Denmark itself — the king having previously been called "Denmark" (I.i.48) as the head of the nation's body politic. Denmark, the physical place, becomes spiritually charged with the duty Hamlet owes his dead father, so the geographical confines exist—as Hamlet cannot seem to leave, not to return to Wittenberg and not long enough to reach England-because of the psychological bounds the former king has placed upon Hamlet's mind. As his commitment to the ghost and his call for revenge increasingly contracts his psychological realm, the more desperate Hamlet becomes to free himself of the chains the ghost has placed on his mind. Hamlet's speech throughout the majority of the play revolves around the two ways he supposes he might escape his mental prison: by killing his uncle, or killing himself. It becomes an internal battle between action and escape, both of which require an act of death. Here, Hamlet resembles the ghosts of the soldiers, who must kill others, or be killed themselves. The author of the pamphlet, fittingly, introduces the start of the ghosts' battle as "the entrance to the game of death" (3). Such a description is equally applicable to Shakespeare's play, but the game of death in Hamlet is a matter of individual psychological warfare: the internal combat of one man against himself. Hamlet exhibits the toll of his mental struggle, a result of having had to carry the burden of remembrance and revenge, when he says to Polonius, "You cannot, sir, take from me that I will more willingly part withal-except my life, except my life, except my life" (II.ii.214-16). While some scholars might suggest that Hamlet's repartee with Polonius is merely 
him putting on his "antic disposition", similar thoughts pervade his speech in the next scene, most notably in his infamous soliloquy, where Hamlet, alone, contemplates life, death and mortality: "whether "tis nobler in the mind to suffer / ... / Or to take arms against a sea of troubles / And by opposing end them?" (III.i.58-61) Taking his own life seems to be an appealing option for Hamlet, especially as the only other alternative he poses is suffering through life, having to carry the guilt of murder unto his natural death. Thus, Hamlet implies that he will suffer whether or not he kills his uncle — killing Claudius would not necessarily produce cathartic justice, but just become another wave in an already tumultuous "sea of troubles".

His aversion to the deed is apparent when he next encounters the ghost of his father, and his fear and desperation mark a stark difference from the enthusiasm he shows the first time they meet. Where once an "honest ghost" (I.iv.143), Hamlet now calls for the protection of the heavens against it - which indicates that he believes that the apparition is not, or is no longer, heavenly (III.iv.96-97). Where once he vowed to obey the spirit's divine-like commandment, Hamlet is now weighed down by the "dread command" (III.iv.101). Furthermore, Hamlet pleads that the ghost "not look upon me / lest with this piteous action, you convert / my stern effects. Then what I have to do / will want true colour...tears perchance for blood" (III.iv.120-123). Hamlet suggests that the ghost's attention on him will cause him to divert from action and that instead of spilling blood, Hamlet will shed tears. Nils L. Anthonisen also notes a dramatic shift in Hamlet's psychology following this second encounter with the ghost, claiming that after Act Three Scene Four of the play, "Hamlet seems prepared to die" (242). In fact, Hamlet has been preparing to die from the beginning of the second act, as the lasting effects of his encounter with the ghost gradually push his psychology to the point where death is the only possible ending. The 
ghost's effect on Hamlet, from the start, is not exterior but interior; it does not move Hamlet to act outwards but to retreat inwards, thus thwarting its own purpose.

\section{Old Hamlet: Ghost, Father, King}

But what exactly is the ghost's purpose? Does the soul of the king return only to see his usurper killed, or does the task of revenge accomplish a larger mission? Here again, I think, the key is memory. For the ghost does not tell Hamlet to "Avenge me"; it says "Remember me", and the act of remembering in the play signifies more important socio-political stakes. It is not only about revenge, but about restoration as well, as a large part of the ghost's anger towards Claudius stems from the fact that "the serpent... / Now wears his [Hamlet's] crown" (I.v.39-40). Claudius is first and foremost a usurper, and the revenge of the son must entail punishing the usurper for his crime. The assumption is that Hamlet himself would take up his father's rightful place, as the memory of the king's death reiterates the necessary ascension of the heir. But this is where the issue of remembrance falters in the play. Hamlet becomes so consumed by the manifestation of memory - that is, the ghost — that he fails to enact remembrance in the way the ghost desires: through action..$^{38}$ Instead, as Hamlet's mind gradually contracts around the psychological aftereffects of the shock of the ghost's appearance, he focuses on the internal act of remembering and thinking about remembering, rather than the outward action necessary for both revenge and restoration. Furthermore, not once in his internal contemplation about the ghost and its call to remembrance does Hamlet explicitly acknowledge the political implications of revenge. While one might expect a son to speak of the honour and filial duty of avenging his father, Hamlet's language lacks such imagery. A reason for this might be explained by Reta A. Terry, who suggests that the traditional honour code changed between medieval and early modern times.

\footnotetext{
${ }^{38}$ See Jean E. Howard's Shakespeare's Ghost Writers: Literature as Uncanny Causality.
} 
Where once ideas of honour revolved around lineage and violence, towards the sixteenth century they became more related to allegiance to the state (1071). But, by failing to remember his place as his father's heir, and the subsequent necessity of placing himself on the throne after Claudius' death, Hamlet demonstrates an indifference to the political future of the Danish state.

Hamlet's failure to consider the political implications of the ghost's call to remember is even more apparent in view of his attitude towards natural succession. For example, he assures Polonius that "conception is a blessing / But not as your daughter may conceive" (II.ii.185-86) playing conception as pregnancy against conception as the birth of an idea, in order to undermine the value of reproduction. However, his harsh sentiments reflect his larger psychological struggle with filial duty, as it is telling that these dismal references to birth and breeding occur frequently after Hamlet's first encounter with the ghost. After the ghost disappears following their first conversation, Hamlet laments, “O cursed spite! / That I was ever born to set it right!” (I.v.19697) and he later admits to Ophelia that "it were better my / mother had not borne me" (III.i.12425). Hamlet knows that he must take on the role of revenger because his filial status in the patriarchal line demands it, and evidently he feels the burden of his duty as soon as he is assigned it, to the point where he would rather retreat into the womb than have to carry out his father's wishes. Furthermore, by telling the woman he supposedly desires to commit herself to a convent, ${ }^{39}$ he implicitly rejects his responsibility to continue his father's line-while refusing to burden a child with a similar life of duty and expectation. By delaying his revenge, and retreating ever further into his own mind, Hamlet secludes himself from political realities upon which the rule of Denmark depends. In so doing, he fails not only to remember his father by avenging his

\footnotetext{
39 "Get thee to a nunnery" (III.i.122).
} 
death, but also by neglecting his duty to take up his father's political seat — thereby failing to uphold ancestral memory by continuing his family's line of kings.

In this way, Hamlet and the 1641 encounter are inversely connected; while the author of the pamphlet assigns a political moral to his text without considering the individual suffering of the dead soldiers or those who witness their ghosts, Shakespeare's protagonist forsakes political considerations because of his all-consuming battle with his own psychology. Yet, the drama links the significance of the ghost, the individual mind and socio-political reality in ways the pamphlet does not. While the onlookers of the ghost soldiers recall their fear, and even admit that the sight prompts them to engage in certain "cogitations" (3), any individual ideas about the encounter are erased by the author's authority. He overlooks such mental meanderings in favour of a moral that accedes to accepted contemporary ideas about both ghosts and civil war. Hamlet, however, demonstrates how the figure of the ghost can spiritually infiltrate a person's psychology, as a visual manifestation of human memory, and a symbol of the familial, social and political significance such memories can have. Shakespeare reimagines the sixteenth-century ghost as more than a tool for one religious faction to assert superiority over the other. He even reconfigures its associations with ancestral memory, as the ghost's surface significance as a symbol of paternity and familial lineage is overshadowed by the psychological effects such patriarchal obligations can have on the ones burdened to uphold them. Unlike in the Edge-Hill pamphlet, where the ghosts recall a memory of war that the author uses to prioritize a message of peace in service of widespread morality_rather than delve into personal significance of the ghosts for those who remember the faces of the men with whom they fought — the Ghost of Old Hamlet fails in its attempt to use memory to perpetuate dynastic longevity — as ancestral memory, and political memory as well, were meant to do. Rather, the memory of the ghost, and 
the ghost as memory, result in Hamlet's narrowing psychology, where conventional ideologies surrounding family and memory are forsaken in favour of an individual compulsion to remember, that eventually collapses the ancestral line altogether.

\section{Free to Forget}

But what is the nature of this collapse? Yes, Hamlet dies childless, and so stunts his family tree. However, I would like to suggest that the ghost's failure becomes evident even before the mass slaughter of the final act. Rather, it occurs as soon as Hamlet feels he can forgo his duty to remember - the moment he kills Polonius, which results in a kind of mental catharsis for the prince. Consider that in the scene before he kills Polonius, Hamlet finds his uncle alone at prayer, and lifts his sword to finally obtain the revenge which will rid him of his ghostly shadow. Not wanting his uncle's prayers to allow him to surpass the fiery torment his father's spirit experiences, Hamlet delays, again. ${ }^{40}$ And the ghost's noose on him tightens, as his mind becomes further enveloped with the task he has not yet achieved. Hamlet cannot afford to delay again, so when he thinks he has his "rat" (III.iv.24) cornered, he strikes. Of course, he mistakes his rat, and so the ghost appears to remind him that his duty is not yet done. However, Anthonisen, I believe, is correct when he observes that Hamlet views death differently after this scene. But the effect of Polonius' death, and of the ghost's final appearance, does not become apparent until the play's finale, when Hamlet's concern with revenge has altogether vanished. He tells Horatio, “in my heart there was a kind of fighting / that would not let me sleep. Me thought I lay / Worse than the mutines in the bilboes" (V.ii.4-6). Hibbard translates this last line as "worse than men in shackles" (n.6 335). Here is a final image of Hamlet in bondage; but, it is significant that he describes this episode in the past tense: there was a kind of fighting, which has now ceased.

\footnotetext{
${ }^{40}$ See III.iii
} 
Why? Because of fortune: Hamlet discovers, "our indiscretion sometimes serves us well / When our dear plots do pall; and that should teach us / There's divinity that shapes our ends" (V.ii. 810). Hamlet's primary "indiscretion" is murdering Polonius and not his uncle. When Hamlet finally takes up his sword to accomplish the revenge the ghost tasks him with in the very first act, fortune makes it so the victim is not Hamlet's intended target. Hamlet, however, thrust with the aim of killing his uncle - the result of that action was entirely out of his hands.

Hamlet seems almost vindicated in not having acted previously, as who was to say that he should have succeeded any earlier, if his revenge should be so thwarted now? For if indeed “divinity shapes our ends", then fate, it seems, would not see Claudius dead before the final act. Moreover, the case of mistaken identity, a mix-up which Hamlet ascribes to fate, thereafter releases Hamlet from the strain of duty he feels until that point. For the first time, Hamlet does what the ghost wanted: he stops overthinking and acts. But even action does not satisfy revenge, and so in the scenes after Polonius dies, the pursuit of vengeance wanes in Hamlet. Even as the ghost appears immediately after Hamlet kills Polonius, his reminder of the revenge yet to be accomplished goes altogether unheeded. Rather, Hamlet's principle take-a-away from the ghost's second visit is in regards to his mother. The ghost tells Hamlet to "step between [Gertrude] and her fighting soul" (III.iv.105), by speaking to her to ease her anxiety. Hamlet begins to engage his mother with a softer tone,${ }^{41}$ and the remainder of the scene highlights the gradual reopening of the lines of communication between the two. Hamlet does not speak of revenge again after this scene.

\footnotetext{
${ }^{41}$ He begins cordially, "how is it with you, lady?" (III.iv.108), but eventually pleads with her to "confess yourself to heaven" (145). His own impassioned confession about his feelings regarding his mother's remarriage-having not been so genuinely transparent with her beforehand - results in her willingness to concede to her son's advice, as she asks "what shall I do?" (169) to avoid committing further sin with Claudius.
} 
Despite his failure to kill Claudius, Hamlet's attempt to act to avenge his father calms the psychological turmoil thereunto surrounding the act of revenge itself. Thus, in the final scene, Hamlet's mind is free of its compulsion to remember - the ghost has been put to rest in Hamlet's mind, and along with it, any affective influence it may have had on Hamlet's psyche is quelled. The result of such mental freedom is that Hamlet becomes able to act with certainty of his own desires, even as those actions lead to his death. However, I believe that Peter Bruce Waldeck is mistaken in claiming that Hamlet's dying moments usher forth a "catharsis of fear" (154). Rather, there is a relief in his realization that "things thus unknown, I leave behind me" (V.ii.298) - the unknown country that might invoke fear is now the world of the living, not the dead - and he expresses pity for Horatio, whom he charges to continue to endure the prison of Denmark, of the world, so that he might relay Hamlet's story (V.ii.301-302). As Hamlet's own spirit leaves his body, he, like his father before him, transfers the call to remember to another body, thereby upholding the spiritual lineage of remembrance that he could not see through physiologically or politically. But, as I have hoped to demonstrate, seating himself on his father's throne was never his primary concern. For, Hamlet was prepared to die early on, and after much mental strain, he finally gets his wish.

\subsection{The Ghost of Andrugio}

In 1678, a pamphlet was published anonymously, detailing the events of a ghost encounter which had taken place in the west of England six years prior. ${ }^{42}$ At that time, a gentleman — a widower and a father — fell sick, and knowing he was soon to die, he arranged his will to "dispose of his Lands to the use of his children." The gentleman made a kinsman the executor of the will, trusting he would see the terms fulfilled. However, after the gentleman died,

\footnotetext{
${ }^{42}$ Taken from a pamphlet published anonymously in 1678, entitled $A$ Strange but true account of an apparition to a certain person that was made executor of a will... Wing / S5881 A, EEBO.
} 
the kinsman fraudulently signed the gentleman's estates over to himself and his own children, “thereby violat[ing] his trust and disinherit[ing] the Orphans of their Patrimony." Having seen the wrong done to these children, "it pleased God" to send the gentleman's spirit back to the land of the living, to prevent "such wickedness from 1[ying] undiscovered." One day while out ploughing the fields, the kinsman's servants were surprised by “a very great noise of a company of Huntsmen that were following the chase after a pack of dogs... and one of the horsemen coming within view was plainly discovered to be the Gentleman...that was lately dead. They had not past far from them [the servants], but on a sudden all vanisht." "In a sore affright", the servants ran to report the scene to the kinsman, who laughed it off as mere fancy. The following day, the same apparitions crossed the field, but this time the figure of the late gentleman "took his course directly to the Master's house and there seemed to enter." The Master again dismissed their frightened rantings; however, "all that night the Family were affrighted with hideous Noises, skreekings, Howlings, clattering together of the Pewter dishes, [and] the throwing to of the doors." This racket continued for several days, and caused so great a disturbance that the neighbours urged the kinsman to seek the council of a minister.

When the local minister arrived and witnessed the phantom disturbances, he suggested that the household engage in a day of fasting and prayer. Nonetheless, the noises continued. Finally, the minister pleaded with God "to signifie the cause of so unusual a Judgment upon that Family" and "on a sudden there appeared to him...the Apparition of the aforesaid deceased Gentleman." The spirit beckoned the minister forward, and, after crossing himself, the minister followed. The gentleman's spirit told the minister "he came from the other world to acquaint them of the wickedness of that person who had violated his trust and wronged his Orphans." As proof of his claims, the spirit indicated to the minister where he might find the original will. 
Before departing, the spirit threatened the minister "in a terrible voice" that "if he did not suddenly make Restitution, [it] would come and teare him in pieces." Following the spirit's instructions, the minister found proof of the cancelled will, and "presently urged it upon the Conscience of him that had by his wickedness been thus the disturber of the Family." The kinsman, "being thus openly as well as inwardly convinced of his sin, presently fell down on his knees and with many tears begged pardon of God...promising speedy Restitution.” After the gentleman's children were restored to their inheritance, the disturbances upon the house of the kinsman ceased.

The encounter between the ghost of the gentleman and the kinsman is atypical among seventeenth-century ghost stories because the author explicitly treats the return of the spirit as legitimate, while still adhering to Protestant belief. For, even the staunchest critics of ghost lore conceded that God had the power to send the spirits of the dead back to the realm of the living if He so chose ${ }^{43}$ and the anonymous author determines that the gentleman's ghost was sent out by the Lord's authority. The pamphlet, therefore, falls in with other contemporary ghost stories, like the Edge-Hill encounter, that are framed by the religious discourse of the day. However, while the Church of England was skeptical about the possibility that spirits of the dead could return to the land of the living, the continuation of ghost sightings well into the late seventeenth-century is evidence that church views and communal belief did not always coalesce. But the 1678 pamphlet is unorthodox in the way it positions the gentleman's ghost in relation to religious belief. The author claims that "the grand concernments of religion and interests of mankind...depend upon the belief of Invisible Powers, and things not perceptible by the outward senses." Here, the

\footnotetext{
${ }^{43}$ See Lavater, Northbrooke, Taillepied and Le Loyer's treatises on ghosts. Lavater publicly criticized both Le Loyer and Taillipied for believing that souls of the dead could return to Earth (qtd. in West 50-51), even as Lavater betrays himself when he concedes that God could choose to send souls back to Earth, though claimed that He never did (West 48).
} 
author uses the return of the gentleman's ghost as proof of God Himself. Despite being largely unseen, particularly while disturbing the kinsman's home, the eventual visual manifestation of the gentleman's spirit demonstrates that there is, at the very least may be, an unperceived spiritual realm, which some people would deny. ${ }^{44}$ In the pamphlet, then, ghosts are not an affront to Protestant morality or the beliefs of the Church of England; rather, they are used to support those beliefs and emphasize the importance of adhering to them, partly because there are unseen presences which are privy to our most sinister acts. ${ }^{45}$

In this roundabout way, the pamphlet nonetheless stresses the need to act morally according to the laws laid down by religious authorities, especially because God may not be the only one watching. By emerging to remind the kinsman of his wrongdoing, the gentleman's ghost, on one hand, is very much a ghost of conscience- here, a tool of the church — not unlike the ghosts of Banquo or Caesar. However, the gentleman's ghost is also defined by his paternal instincts, as he returns not only to reveal the kinsman's crime, but more so to ensure that his children are well-provided for. He does not primarily focus on the wrongs done to himself, but on the consequences of those wrongs for his children. The ghost, thus, manifests to avenge the living, as part of a larger narrative that promotes the traditional duties and expectations of patrimony.

\footnotetext{
${ }^{44}$ The author refers to such people as "Saduccees", which were members of a Jewish sect around 70 AD who "denied the immortality of the soul, bodily resurrection after death, and the existence of angelic spirits" (brittanica.com).

${ }^{45}$ Keith Thomas notes that as the seventeenth-century proceeded, the fear of the Church hinged less on the dangers of Catholicism and more on the creeping threat of atheism. In this regard, the belief in ghosts, despite being steeped in papal tradition, was preferable to the alternative: the total absence of divine belief altogether (Thomas 720). This pamphlet seems to reflect the changing perception of threats to religion and traditional morality, as is evident in its use of ghosts in order to encourage people towards continued belief in the spiritual and the unseen.
} 


\section{Woe is Antonio}

In Antonio's Revenge, the situation is quite the reverse, and such a reversal challenges conventional ideals about paternal and filial duty. Characteristic of a revenge tragedy, the ghost in Antonio's Revenge returns to its son to encourage him to seek vengeance for his wronged, murdered father. Like the ghost in the 1678 pamphlet, the Ghost of Andrugio verbally confirms the identity of its perpetrator. However, by the time the ghost arrives to tell the tale, the "revelation" is anything but surprising, since the first two acts make Piero's guilt explicit—he openly admits to the deed to his henchman, Strotzo. But even for those who are not privy to Piero's confession, there are numerous suggestions to levy suspicion against him for the murder. For one thing, Piero and Andrugio were long-time romantic and political rivals. ${ }^{46}$ Furthermore, Piero admits to Pandulpho that he has killed his son, Feliche (I.iv.11), and so he demonstrates that he is capable of committing murder. Despite Piero's negative history with Andrugio and his violent inclinations, Antonio fails to piece together enough even to openly suspect Piero. In fact, Antonio gives no thought at all to the fact of the murder; instead he concentrates solely on his own woefulness as a victim of tragedy. Antonio seems determined to be "the most wretched / the most grief-full, despairing" son (II.iii.15-16), insisting "my pined heart shall eat naught but woe" (II.iii.18). He cannot even be moved from his debilitating sadness to fight for the woman he loves. Mellida, charged with adultery, is sentenced to die, but rather than conceive of a way to save or comfort her, he only laments not having "present power for ought but pity" (II.iii.107)— though, judging by his demeanour, it is uncertain whether that pity is for her or himself.

In essence, Antonio's problem is the inverse of Hamlet's. While both men begin a psychological retreat inwards after hearing about the death of their fathers, Hamlet's internal

\footnotetext{
${ }^{46}$ I.i.22-23. Piero also takes up Andrugio's position as Duke after the murder.
} 
turmoil centres on an obsession with his dead father, whereas Antonio seems to forget his father altogether in order to indulge his own misery. If Hamlet experiences an excess of remembrance, Antonio fails to remember at all, and it is this negligence, I believe, that prompts the appearance of the Ghost of Andrugio. The early moderns closely linked memorial reverence for the dead to the state of the soul in death. In addition to the Catholic notion of purgatory-wherein people were expected to remember the suffering of the souls of their loved ones in limbo, and so pray for their ascension into heaven-Keith Thomas also notes that the people of sixteenth and seventeenth-century England believed that a soul of the recently deceased could return to earth if his/her dying wishes had not been fulfilled (721): that is, if the living had forgotten to carry out such wishes, thereby showing disrespectful irreverence for the dead. Such seems to be the case in Marston's play; Andrugio's ghost appears because Antonio has failed to show reverence to his dead father by investigating the circumstances of his sudden death. The ghost suggests as much when its first words after appearing are "thy [Antonio's] pangs of anguish rip my cerecloth up" (III.i. 32). The ghost says, then, that Antonio's self-obsessed misery has literally unravelled it from the throes of death and prompted it to rise in protest of the son's failure to honour the father by avenging — at the very least, ascertaining the cause of - his death. When Piero, in his false surprise at hearing of Andrugio's death, asks Strotzo the cause of death, Strotzo suggests that Andrugio died from a kind of sickness that left his body too cold to sustain itself. (I.iv.9-13). However, the explanation is vague - where might he have caught this sickness, and why did no one notice until it was too late? Nonetheless, Antonio seems to accept Strotzo's explanation without question, and goes on to lament his own misfortune at being suddenly fatherless. The ghost, therefore, is a much-needed reminder for Antonio that he owes the spirit of his father a filial debt of honour, which can only be paid in the form of revenge. 


\section{Obey Thy Father}

By appearing to Antonio to demand vengeance on its own behalf, the Ghost of Andrugio aligns itself with several other contemporary revenge ghosts $;{ }^{47}$ however, in doing so it stands in significant contrast to the action of the gentleman's ghost in the 1678 pamphlet. The gentleman's spirit does not appear to the orphans to reveal the truth of the kinsman's betrayal, nor does it task the children with setting right the wrongs done to him and them. Instead, the ghost is active in perpetrating its own revenge; it uses his supernaturalism to make the kinsman and his family fearful, and it strategically crafts an ultimatum whereby the emotional state of the kinsman's family (i.e. whether or not they should continue to live in fear) is dependent on the restitution of the will. By taking the task of vengeance upon itself, the gentleman's ghost continues to embody the role of the ideal father even after death; it protects the children from having to engage in revenge schemes which, as Antonio proves, can be harrowing. Furthermore, the gentleman's spirit acts not in its own interest, but for the purpose of ensuring the financial well-being of the children; by putting the children before its own personal desire for revenge, the ghost acts an altruistic protector as well. The gentleman's ghost emphasizes the benefits inherent in a patriarchal hierarchy that expects the obedience of lower tiered offspring, yet returns such willful submission by acting with the best interests of their children in mind.

But by burdening Antonio with obtaining revenge, the Ghost of Andrugio stresses the importance of filial duty to the father, regardless of the consequences fulfilling that duty might incur for the son. The ghost's focus is not on its son's well-being, but on its own, and it continues to encourage Antonio to act regardless of the effect such violence might have on his psyche.

\footnotetext{
${ }^{47}$ For example, this occurs in Hamlet, when the ghost appeals to his son to seek vengeance (see previous analysis in this chapter), as well as in Middleton's The Second Maiden's Tragedy, when the Lady's ghost appears to her former lover, Govanius, to restore her body to its resting place, and again in Webster's The White Devil, where the ghost of Isabella appears to Francisco, Isabella's brother, to signal the fact of her murder.
} 
Moreover, the Ghost of Andrugio does not appeal to Antonio through empathy, like Old Hamlet's ghost; rather, the ghost emphasizes the shared lineal connection between father and son, and the subsequent emotional debt such a connection engenders. The ghost's spiritual appeal to lineage and physiology implicitly follows early modern beliefs in the relationship between the external and the internal, the body and the mind/spirit. From Galen's humoural theory, ${ }^{48}$ to the idea that "every ruling passion effects and shapes the whole body" (Roffe 5), early modern English concepts of psychology were rooted in an assumed interplay between external and internal senses. Robert Watson observes a similar presumption working in the relationship between Hamlet and the ghost of his father; the nature of Hamlet's reaction to the apparition, "the blank staring, the collapse into silence...suggest that this ghost infects those he encounters with a version of its own unredeemed deadness...its insistent 'Remember me' translates into 'memento mori', not an extension of life, but an invitation into death" (84). As I have noted in my analysis of the play, that invitation into death resonates both psychologically and physically in Hamlet, who begins to aesthetically resemble a man nearing death as his thoughts turn increasingly towards issues of human mortality. I argue that a similar infection occurs in Antonio's Revenge between the Ghost of Andrugio and its son. This is evident even before the ghost appears, when Antonio dreams of his father's spirit, and wakes up in a frenzied state. He recalls seeing a ghost that "assumed my father's shape", "whose bubbling gore sprang in frighted eyes" (I.iii.44-45). Antonio himself then wakes with "trembling joints / Iced quite over with frozen sweat" (46-47) — he physiologically emits the fear that he sees displayed by the mere thought of his father's spirit, and his sudden physical frigidity is a literal transmission of his

\footnotetext{
${ }^{48}$ The theory of the humours draws an intricate connection between inner and external health; for example, a physician might prescribe changes in diet and exercise for one who was believed to be suffering from melancholy and thereby experiencing mental hallucinations, as a change in physiology was thought to affect a change in the mind as well (see Robert Burton's Anatomy of Melancholy, 5).
} 
father's newly cold body. He also finds that his "nose straight bled" (59), just as the ghost's breast "seemed fresh-paunched with bleeding wounds" in the dream (43). Furthermore, Antonio claims he "leaped forth the sheets" (48), and as soon as it appears, the Ghost of Andrugio, too, claims that "pangs of anguish rip my cerecloth up" (III.i.31) — there is a parallel between the actions of the son's body and the father's spirit which Marston continues to emphasize throughout the play.

This link is strengthened in the physical language the ghost uses both to reiterate Antonio's innate duty to avenge his father, and to physically and affectively move Antonio towards action. The ghost's rhetoric emphasizes tangible action, as it encourages Antonio to "seize" and "grasp", claiming that it will visit Andrugio's former wife, Maria, before "I touch / the banks of rest" (III.i.42-43, 45, emphasis mine). Moreover, within the span of four lines, the ghost demands three times that Antonio "Revenge my blood!" (III.i.34-37) The invocation of blood is dually significant: literally, the ghost references the lineal connection between the bodies of father and son, but figuratively, it links that connection to a more abstract expectation of familial loyalty that is linked to physical ties. The ghost then calls Antonio "thou vigour of my youth, juice of my love" (III.i.44); the repetition of the possessive "my" makes clear the hold the spirit is attempting to assert over Antonio. The ghost also refers to the son in terms of the effort Andrugio himself exerted in contributing to Antonio's very existence. "Vigour of my youth" and "juice of my love" both connote the sexual act and resultant insemination required for conception. Antonio, therefore, is a physical extension of his father and, as such, Antonio owes his life to the man whose spirit calls on him now to act on his behalf. The ghost's emphasis on the physical connection between the two has an evident psychological impact on Antonio, who acknowledges the "infectious damps of clammy graves" (III.ii.26), and later concedes, "death, 
like to a stifling incubus, / lie[s] on my bosom... / My breast is Golgotha, grave for the dead" (IV.iv.21-23). Like the sunken-eyed, mentally unravelling Hamlet, Antonio's interaction with the ghost of his father results in a psychological mirroring of that paternal spirit, such that he becomes particularly susceptible to the influence of the ghost, which is rooted in the shared lineage between father and son.

\section{Childish Things}

The Ghost of Andrugio asserts its influence over Antonio's psyche by emphasizing his authority as a father and intimidating patriarch, in order to strong-arm the son towards revenge. In so doing, the ghost uses its paternal position to affect a fearfulness in Antonio which subverts him to the status of an obedient child. The extent of the ghost's affective power is evident when Antonio tells his mother, "I be cursed by my father's ghost /... / If my heart beat on ought but vengeance" (III.ii.34-36). While Antonio seems to speak as a son willing to commit himself to the cause of his father's spirit, his concern with being "cursed" hints at fear of the ghost's wrath, especially considering a few lines later he says "graves and ghosts / Fright me no more" after the voice of the ghost reminds him to "murder" (III.ii.74, 76-77). As Antonio proceeds to kill, and to kill violently, he does so as a child who seeks to please his father, who is fearful of the consequences should he displease him. In the introduction to the play, W. Reavley Gair makes a similar observation, noting that in the work, Antonio is treated like a child (Marston, 36). I would extend Gair's claim further: if Antonio is treated like a child, it is because this is a role he accepts for himself - indeed Antonio refers to himself as a child several times throughout the play. When Antonio learns about Mellida's death, he claims that God "gavest her to me, as some weakbreasted dame / Giveth her infant, puts it out to nurse" (IV.iv.7-8), and a few lines further, he claims "I am a poor, poor orphan; a weak, weak child" (IV.iv.14). He calls himself "sore poor 
orphan" (II.iv.3), despite the fact that his mother is yet living. The image of an orphan not only augments his destitute woe, it also connotes a small, helpless child. Antonio, however, is a grown man, and the discrepancy between image and reality reveals a fragile and vulnerable psychological state that finds some sort of anchor in the ghost and his task. It is important to note that Antonio refers to himself as a child both before and after the appearance of the ghost. The difference, however, is that before the ghost's appearance, his self-proclaimed childishness serves to justify his inaction and excessive woe; afterwards, his child-state becomes an automatic reflex to being confronted by his father's spirit. The child is no longer fully alone, and he is given a mission, a purpose, to save him from aimlessly wandering in sorrow.

More than anywhere else in the play, Antonio clearly adopts the role of the child in regards to his revenge task. The violence of his actions is a symptom of his childish need to please his father, out of fear of the power his father yields even, and perhaps especially, in death. Unlike Old Hamlet, whose ghost calls on his son to "Remember me"- thereby initiating Hamlet's increasingly narrow psychological obsession with the act of remembering his father, rather than directly avenging him — the ghost of Andrugio tells Antonio to "Remember this: / Scelera non ulcisceris, nisi vincis (III.i.50-51, emphasis mine). Gair translates Andrugio’s command from Seneca's Thyestes as: "You do not avenge crimes unless you conquer". The difference in the ghosts' imperatives proves to be significant, as the Ghost of Andrugio's influence over the vulnerable psyche of his son produces a zeal towards excessive violence. Indeed, Alistair Irwin MacDonald argues that the ghost's command forces the play towards "a Senecan blood bath" (126), and such is evident in Antonio's decision to kill Julio, Piero's son.

The extremity of Antonio's action becomes especially apparent if one compares the role of Piero's kinsman in the play with that of the gentleman's kinsman in the 1678 story. In the 
latter, the kinsman brings the wrath of the spirit — and God, by extension — on himself because he has neglected to fulfil the wishes of the deceased. Therefore, the kinsman is directly responsible for the ghostly disturbances of his family and the fear that follows from them - they become necessary catalysts in his admission of guilt and the righting of his wrongs. However, Julio, as Piero's kinsman, suffers only because of his relation to Piero. By killing not only Piero, Antonio attempts to fulfill the ghost's demand for vengeance by surpassing Piero's own crime-Antonio will not only murder the father, but the son as well. Julio himself is an innocent, and Antonio acknowledges as much when he tells Julio, “it is not thee I hate, not thee I kill. / Thy father's blood that flows within thy veins / Is it I loathe" (III.iii.34-36), as though by stabbing Julio, Antonio drains Piero's own blood. Antonio further laments, “O that I knew which joint, which side, which limb / Were father all and had no mother in't, / That I might rip it vein by vein and carve revenge / In bleeding rases!” (III.iii.20-24). Here, Antonio suggests that there are indeed parts of Julio which are "father all", which exist as if they belonged to Piero himself because his blood flows through them. Julio, therefore, is killed because of his intimate familial association with Piero, just as Antonio is burdened with the task of Andrugio's revenge for the same reason. Moreover, Antonio's speech highlights the violent expectation of eradication inherent in patriarchy; in order to honour both his father's spirit and the memory of his ancestral line, Antonio must cut off the dynastic continuance of another family. Killing Piero would not be sufficient; by murdering Julio as well, Antonio guarantees that Piero's blood will never flow in any others, ever again. This excessive action counters the more direct aim of the gentleman's spirit in the pamphlet, which is to restore the hereditary rights of its children — any thoughts of revenge against the kinsman himself are secondary. If the pamphlet shows the moderate, though 
watchful, protective spirit of paternity, then Marston's play exploits the potential for paternal influence to dominate all other instructive ideological systems - moral or otherwise.

Blood of my blood

Antonio further demonstrates this need to please his dead father's spirit in the ways he treats Julio's body. It is important to note that Antonio, when faced with his own decision about whether or not to kill an innocent and the whimpering Julio, hesitates to carry out the deed. Just as he decides to "flag revenge" (III.iii.29), the ghost reappears and demands murder, to which Antonio immediately responds "Stay, stay, dear father, fright mine eyes no more. / Revenge as swift as lightening bursteth forth" (31-32). Antonio's knee-jerk reaction to the appearance of the ghost, and his plea to be frightened no more by the spirit of his father, indicates that much of his violent action is directly influenced by his fear of the presence of his father's spirit. Like a scolded child, Antonio cowers against his previous conviction to stay revenge, and continues with the murder under the looming shadow of his father's ghost. Once the deed is done, Antonio parades the proof of it around the stage, as a youth might show the bounty from his first successful hunt. Antonio holds Julio's body up to display it. But for whom? The answer comes immediately after, when stage directions indicate there is an audible groan from below. Antonio follows this proud display by exclaiming, "Here stands Andrugio's son / Worthy his father" (III.iii.52-53). Here, Antonio forsakes his individuality in order to emphasize his parentage; he is not merely Antonio, but Andrugio's son. He, thus, willingly succumbs to the patriarchal possession which the ghost enforced in his first speech ("vigour of my youth" etc.). He further asks the ghost to "look how I smoke in blood, reeking the steam / of foaming vengeance" (III.v.17-18), insisting that "this is Julio's blood; / ...this is Julio's blood” (III.v.21-22). Antonio's rhetoric is riddled with elements that indicate he is seeking his father's approval; for 
instance, asking the spirit to "look" is reminiscent of a child impatiently trying to show off to his parent. The repetition of "this is Julio's blood" serves as a strategy for persuasion, as though Antonio is assuring his father that he did indeed kill Piero's son. Antonio's need for visual and verbal acknowledgment harkens back to his holding up the bleeding body for, presumably, the ghost to see, again as proof of his achievement.

There is a significant tie between the ghost's call for violent revenge, Antonio's consistent associations with blood imagery in the play, and the gradual increase in his child-like psychology. According to the Galenic system, blood as a humour was associated with infancy (Galen 49), and Antonio's zeal in pursuing vengeance seems steeped in a juvenile desire to please, and so release, the spirit of his father. The idea that the non-corporeal ghost could somehow be sated by bodily means, like the spillage of blood, reiterates the inextricable link between physiology and psychology in the play, particularly where the influence of the ghost is concerned. Antonio claims as much when he says, "blood cries for blood" (III.iii.71)—an observation which again expresses the dual significance of blood imagery in the play. While his subsequent observation-“murder murder craves" (71)—makes his first claim seem little more than a nod to the dangerous, addictive potential of violence, the blood imagery here is much more telling if viewed in terms of the ghost's affective influence in the play. From his first appearance, the Ghost of Andrugio demands that Antonio honour his lineage by punishing those who sought to harm his family line; the ghost does so by calling the son to "revenge my blood...rouse up thy blood" (III.i.36, 47). Here, blood is literally crying for blood: the ghost recalls the spillage of its own body's blood to drive Antonio to not only avenge the now cold blood of his father through spilling the blood of their enemies, but to recall that that blood, his father's, is also his own. Their shared lineage makes it so Antonio owes it both to his sire and to 
himself to seek revenge. By acknowledging that "blood cries for blood", Antonio, therefore, justifies his murder of Julio as a son performing filial obligation to his father. The violation of Julio's bloody body, both through the murder itself and by putting the body on display, becomes necessary in order for Antonio to fulfill his own blood bond - in his mind, the consequences of grotesque violence pale in comparison to the familial loyalty owed between child and parent.

The Ghost of Andrugio seeks a physical solution to his spiritual problem, and Antonio emulates the ghost's intent when he, too, seeks to supply a physical remedy for the wandering state of his father's soul. After killing Julio, Antonio "allows Julio's blood to fall upon the [Andrugio's] hearse" (III.iii.61-62), and calls the spirit to "suck this fume; / ...perfume thy circling air / With smoke of blood. I sprinkle round his gore / And dew thy hearse with these fresh-reeking drops" (63-66). Antonio engages in a semblance of perverse organic reproduction, wherein the blood of the enemy is somehow able to nourish the spirit of the dead. By tainting natural imagery in this way, Antonio, while implicitly referencing the contemporary belief in the intimate link between the body and the spirit, suggests that there is something unnatural in the fact that the blood of revenge should be demanded, even required, to serve the ancestral spirit and uphold familial honour. As such, Marston's play has been a difficult one for early modern audience and critics alike to accept, because it re-constructs the contemporary relationship between the body and soul in order to question the validity of the conventional relationships which are at the core of sixteenth-century socio-political ideologies.

Through his excessive zeal for revenge, Antonio privileges the lineal and emotional tie to his earthly father, while showing little care for the state of his own soul. Aforementioned, Phoebe Spinrad has also observed a problematic reversal in the familial and spiritual patrilineal hierarchies - where the will of God the Father should conventionally be expected to guide a 
person's thoughts and actions, Antonio replaces the will of the heavenly Father with that of Andrugio's spirit (Spinrad 178). The result is that Marston's play forsakes early modern ideas of what is right and just according to traditional morality, instead replacing those contemporary ideals with the individual desire of a desperate, woe-begotten son to appease the spirit of his father. Where seventeenth-century religious discourse emphasized that the actions of the body should retain consideration of the future of the soul — the physical act of fornication, for example, could have a damning effect on the soul after death-Antonio's psychological journey throughout the play disregards this conventional relationship between the body and the soul. Instead, Antonio comes to link the actions of his body with the state of his father's soul—he must kill so the Ghost of Andrugio can rest at last. The problem is that in so doing, Antonio confuses his patriarchal loyalties, deprioritizing his eternal bond with God in order to fulfill earthly ideals of filial obligation and familial honour. This hierarchical reversal is the reason why morality is largely inconsequential in Marston's play. In Antonio's mind, the idea of right is determined by his ability to bring his father's murderers to justice, regardless of whether his methods make him just as guilty as those he seeks to punish.

\section{The Law of Revenge}

The complex relationship between revenge and morality that Marston explores in his play reflects contemporary common understanding of the way the two could work in tandem, at least at the earthly level. Marguerite A. Tassi notes how the language of "debt and obligation", which appears in the works of playwrights like Marston and Shakespeare, stems from ideas of "lawful revenge" that "embody the reverse-ethics of honor-based cultures" (55). However, Tassi, like Terry, acknowledges that Elizabethan England was not known as a culture of violent revenge, but nonetheless observes that it was a culture where "revenge, justice, honour, moral debt, grief 
and shame are all part of the same genetic material" (66). Furthermore, Tassi claims that "a reflexive turn to vengeance as a force that regulates shame and honour is pervasive" in the literature of the period. Antonio's Revenge is evidence of her claim, as Antonio is motivated to seek vengeance for his father both by a sense of filial duty to uphold family honour, and by his own shameful inaction up to the point that his father's ghost appears.

Along similar lines, Ronald Broude marks an important distinction between the word "revenge" as we think of it, and the concept as it was understood in the sixteenth and seventeenth centuries. Broude notes that "revenge" in the Renaissance meant something more akin to "retribution"-it encapsulated punishment that one rightly deserved for crimes committed, not strictly personal vengeance (40). Moreover, Broude writes that "revenge" might indicate punishment inflicted by the individual and/or family of those directly affected by the crimes of another, or could describe "the punishment meted out by the commonweal for acts defined by statute or custom as contrary to the public good" (41). This latter case gives revenge in the Renaissance a kind of political moral high ground, and speaks to the leniency with which the Venetian statesmen treat Antonio's murder of Piero, which I will discuss further in the next section. However, both Broude and Chris McMahon agree that viewing revenge as a vehicle towards the political and public good largely depended on motive— - revenge could be deemed morally just or un-Christian by early modern society based on what drove the revenger to act. For example, Broude calls Hamlet "the righteous agent of God's vengeance upon the secret criminal [Claudius]" (55); for Broude, Hamlet's revenge is moral and so justified because he strives to expose the heinous crimes of his uncle, and, so, to right the wrongs unjustly done to his father. Readers and audience might consider Antonio in the same vein. However, the situation 
becomes complicated when one remembers Antonio, unlike Hamlet, intentionally inflicts revenge not only on the guilty Piero, but also on his innocent son.

This is where the state's leniency becomes distressing for reader and audience alike, and where Marston's play steps outside the boundaries of even "lawful revenge". Instead, Antonio violates acceptable codes of retribution, and even though he is lauded for his action at the end of the play, he nonetheless transgresses "the spirit of the law"- a phrase Noam Reisner references in his discussion of Pauline imperatives and early modern revenge tragedies. Paul states that "it is the spirit of the law which is eternally binding, not the external pronouncements of the letter" (qtd. in Reisner 154). Although Reisner analyzes Paul's words in terms of Vindice's quest for vengeance in The Revenger's Tragedy, much of what Reisner observes is equally applicable to Marston's play as well. Reisner highlights the distinction Paul makes between the spirit and the letter; the former "appl[ies] not to the transient life of this world, but to life everlasting" (153). Therefore, even if Antonio's actions are "externally" rewarded by social praise, and even if the murder of Piero is "culturally sanctioned", his revenge nonetheless violates a higher Christian law, where only God has a right to punish the wicked. Reisner recognizes the problematic conflation that revenge tragedies, as reflections of their contemporary socio-political climate, make between political and moral law. Again, he quotes Paul, who claimed, "sin is only made possible because of the law, and that is why precisely Christians should rise above the law's flesh-bound limitations, relying instead on a transcendental spiritual corrective" (155). By referencing Paul here, Resiner acknowledges the potential manipulations and abuses of power that can result when revenge becomes publically or politically sanctioned as a moral good—such is evident in the fact that Julio's murder is altogether overlooked by the people of Marston's Venice. Resiner argues that by displaying the negative potential of law to create widespread 
transgression, revenge tragedies remind people that God, not secular law, is the sole determiner of what is good and just, and only those who follow His laws will be rewarded. However, rather than demonstrate this by punishing Antonio for his individual deeds, I argue that Marston's play promotes adherence to God's will by punishing the patriarchal system that promotes the kind of ancestral revenge that Antonio undertakes. It does this by upsetting patrilineal circularity, whereby Antonio punishes himself for his sins by choosing an isolated life dedicated to God, purposely retreating from the world of men, the values of which drove him to such extreme action.

A Surprising Turn

As many critics of the play have observed, the final tone of the play is odd in that it seems to support, rather than admonish Antonio's skewed perception of conventional morality. Instead of being punished for his own crimes, the state senators dismiss any fault in his action on account of him ridding the city of the tyrannical Piero - interestingly, no mention is made of the murder of his innocent son. However, their leniency comes as a surprise to even Antonio, who admits, "we are amazed at your benignity" (V.vi.28). He is almost offended when, after five acts of embodying the role of a child, one of the senators refers to him as "poor orphan" (V.vi.19). Antonio reacts with indignation: "Poor? / Standing triumphant over Beelzebub? / Having large interest for blood and yet deemed poor?" (V.vi.20-22) After obtaining a surplus of the enemy's blood, having killed both Piero and Julio, it is telling that Marston would have Antonio "deemed poor". For, since the first appearance of the ghost, Antonio has sought to pay his familial debt to his father, and the required currency has been blood. Now that he has amassed more than what was demanded, to be looked on as "poor" implicitly denies the validity of all his violent effort. The price paid to solidify his own blood bond with the spirit of his father, to fulfill his filial 
expectations, has accrued little value — and I believe that this meaningless result contributes to Antonio's final turn away from political life.

Charles and Elaine Halletts' observations about the Ghost of Andrugio, discussed in a prior section of this chapter, aptly illuminate how the state's anticlimactic reaction to Antonio's crimes sparks the final volta in Antonio's psychological journey. The Halletts critique Marston's dual treatment of the ghost as both divine agent sent by God for moral purpose and amoral pagan revenger. As Marston hints at the fruitlessness of Antonio's killing spree and his overall bent on vengeance, the implications of the ghost's affective influence force the audience to consider some uncomfortable questions. Does the ghost act in service of a more individual justice, but justice nonetheless, by coercing his son towards murder? Or, does he embody the spirit of the devil by sending Antonio on a fast track of unforgiveable sin? Ultimately, should Antonio feel pride in his accomplishment, or should the weight of his crimes burden him beyond any small consolation the rest of his father's spirit might offer? Marston never provides a definitive answer, and Antonio's final actions preclude any sort of clarity. While he does not deny his actions, he does not engage in celebration either; rather, he concludes the play in a kind of solemnity that reflects his own uncertainty about the righteousness of his revenge. For despite all of his effort, Antonio remains the fatherless child he has been thereunto, neither solely recognized for the scale of his atrocities - he has to fight with Pandulpho and Alberto to claim credit for killing Piero (V.vi.1-9) — nor necessarily successful in honouring the memory of his father, because at the end, Antonio never speaks of filial duty, or expresses any satisfaction in having successfully avenged his father's death. Instead, for the first time since the ghost's appearance, Antonio rejects his position as a son. Rather than accepting the offer to take his father's position as duke, Antonio turns away from patriarchal inheritance. Raymond Rice argues that Marston's ending is 
truly transgressive because Antonio rejects symbolic, patriarchal Law at the end (312); by refusing to take up his father's political position, and choosing to enter a religious order instead (V.vi.35), he subverts ideas of filial inheritance which have previously driven him to excessive bloodshed. Whereas near the beginning, the Ghost of Andrugio uses its authority as a father to terrorize Antonio into inheriting the revenge that the ghost himself, an incorporeal essence, could not perform, by the end Antonio refuses the role of son and dutiful child that the ghost insists upon by denying his political right. What, after all, has filial obligation granted him except a return to the woeful condition in which the audience first finds him —-fatherless, besotted with grief and alone?

After he is praised for killing Piero, Antonio, rather than take the opportunity to recall the memory of a wronged father, whose memory he has now honoured through vengeance, turns again to grief and sadness. Now, however, his grief is not for the father whose spirit has been laid to rest, but for the woman who he previously dismissed because of his obsessive self-pity. However at the end, Antonio will no longer be pitied, not by others, and not by himself. His emotional energies are redirected to Mellida, in whose name he vows celibacy and a life of sorrowful contemplation (V.vi.39-41). This is where the Ghost of Andrugio's failure becomes most evident. Unlike the gentleman's ghost, which ensures the well-being of its own line by seeking to provide its children with the resources they need to thrive and multiply, the Ghost of Andrugio seeks to emphasize its paternal authority in order to frighten the son towards vengeance. However, the psychological effects of this intimidation result in Antonio rejecting larger patriarchal aims. By refusing to marry and procreate, Antonio ensures the termination of his father's line, and in so doing, he openly defies contemporary expectations of a dutiful son to honour the memory of his ancestors by continuing their dynastic line. When Antonio puts his 
father's ghost to rest, so, too, does he bury thoughts of ancestral obligation-which commissioned his psychological dependency and bloodthirst in the first place, only to result in a rather unsatisfying end. Here, Marston's play concludes with moral ambiguity. And just as Antonio is motivated by a father whose spirit cannot rest until his murder has been avenged, that same enthusiastic son enters into a solemnity that seeks to push all thoughts of his father, and the crimes committed in his name, aside. The play denies readers and audience moral closure. Rather, they, like Antonio, are left in a state of psychological disruption and uncertainty.

\section{$\underline{1.5 \text { Coda }}$}

In the end, the Ghost of Andrugio achieves what the spirit of Old Hamlet cannot: it successfully moves its son to avenge its death. However, Antonio's vengeance does not free him from the influence of the ghost. Rather, Antonio remains constrained by the consequences of filial duty throughout the play, and is left with naught but the empty result of having fulfilled his familial obligation. While the memory of the Hamlets will live on through Horatio, Antonio intentionally silences his own ancestral memory by turning away from the court and banishing himself to the quiet life of the church. In so doing, Antonio imprisons his father's memory within himself in the same way Hamlet does at the start of his psychological journey. The result is that, while Hamlet may appear to be the more tragic of the two dramas because of the mass death scene at the end, Hamlet himself finishes his dramatic journey the more fortunate of the two, for he is no longer burdened by the memorial weight that has thereunto determined the state of his psychology.

Hamlet and Antonio's Revenge invest in a similar critique of how traditionally accepted institutional ideals of filial duty and patriarchy can undermine the very moral and religious ideologies in which such ideals are rooted. However, Hamlet and Antonio challenge these ideals 
in very different ways; Hamlet succeeds in freeing himself from them, while Antonio punishes himself for the carnal violence and morally ambiguous justifications for such violence, that his adherence to those ideals incite. For both men, the ghosts of their fathers play a pivotal role in revealing the problematic cost of patriarchal belief, even as the ghosts are themselves symbols that exist within that same ideology. Where ghosts often literally and figuratively symbolize the importance of ancestry, Shakespeare and Marston manipulate this traditional figure of the ghost in ways that challenge contemporary socio-political and moral systems of thought. As with the sixteenth and seventeenth records of ghost encounters, these playwrights describe their ghosts in terms of common folkloric tropes; the Edgehill ghosts and the Ghost of Hamlet appear after midnight and are only permitted to walk until dawn, and they, along with the Ghost of Andrugio and the spirit of the gentleman, leave their witnesses in a state of paralytic fear. The difference between the historical and dramatic narratives is that while the non-fictional encounters tend to neglect the psychological impact of these strange and shocking apparitions, both Marston and Shakespeare delve into the affective influence these paternal spirits can have on the psyches of those to whom they appear. Where pamphlet authors of historical encounters subvert the potential significance of the supernatural beneath conventional moral frameworks, these dramatic ghosts instigate psychological processes that ultimately challenge conventional beliefs about patriarchal expectations and moral ideals. 


\section{Chapter Two Beloved Ghosts, and the Gender Complexities of Desiring Death}

In sixteenth and seventeenth-century England, ghosts undergo a significant transition, from outcast figures emblematic of religious defiance, to spiritual representations of sociopolitical memory. On the early modern stage, they experience an even more specific transformation, which Sarah Outterson-Murphy aptly describes as a movement from ghosts as spectators towards being more fully involved in the world of the play (111). She observes that "by presenting ghosts as subjective experiences of a single individual, these plays ultimately draw attention to the ghost's effect on that particular individual"; as a result, "ghosts begin to shape the experiences of their onstage spectators" (111). In the first chapter, I argued that the powerful effect of the ghosts in Hamlet and Antonio's Revenge stems from a psychological affect — propagated through empathy, a sense of lineal and filial duty, between the rational soul of the ghost and the vulnerable mind/spirit of the protagonist. The result of the ghost's affective potential is a psychological resistance to conventional early modern modes of thought and belief pertaining to expectations of gender and personal social relationships which underpin patriarchal systems of power. On stage, ghosts, previously ingrained in religious and political systems, are suddenly able to uproot those systems from within them - representations of ancestral memory that challenge the validity of patrilinearity, figures of paternalism that question what it means to be a man. Through their revision of traditional ghost lore, Shakespeare and Marston emphasize the need for characters and audience alike to internally and critically re-evaluate their beliefs about the societies they inhabit, and their roles within those communities.

It is not only the ghost of the father, however, that has the power to affect characters this way on the early modern stage. The ghost of the loved one has just as significant an impact on the lover to whom it appears, though by appealing to different aspects of a character's 
psychology. Middleton's Second Maiden's Tragedy and Chapman's The Revenge of Bussy

D'Ambois demonstrate how the spiritual nature of the ghost - a rational soul whose memorial and imaginative faculties have the potential to infect the spiritual countenances of those to whom they appear-can reinvigorate emotional attachment between the living and the mere images of those dead they once loved. For Govanius and Clermont, this resurrected attachment is felt so strongly that it invokes a desire for death in order to reunite with the deceased beloved. Faced with the ghosts of the Lady and the Duke of Guise, respectively, both men recall the intimate connection they share with the dead whose spirits appear before them. They realize that their love is not limited by life or the body, but exceeds such temporary bounds and continues into the spiritual realm of the afterlife. Such attachment is typical of heterosexual love stories, so this desire to die for his beloved Lady is to be expected from Govanius. For Clermont, however, his unwillingness to live without his friend the Guise supersedes traditional sixteenth-century ideas of male friendship. More than companionship but not quite amorous, the appearance of the ghost unveils the complex nature of the relationship between the two men, which blurs conventional expectations of male intimacy, as well as the degree of emotional attachment a man can and should show towards a peer of the same gender.

Despite Govanius' conventional relations with the Lady, the psychological impact of her ghost on him also resists early modern masculine ideals, as it is the Lady herself, both when living and as a soul of the dead, who takes on customary male qualities by demonstrating conviction, firmness, and moral superiority in the face of death. Her strength and courage serves to emphasize Govanius' lack of similar qualities, as he fails to protect the virtue of the one he loves in favour of holding to his selfish desires, while allowing the overwhelming emotional charge of the situation to override his reason and good judgement. The ghost of the Lady returns 
to call Govanius to redeem his past failures, and while he succeeds in his promise, he continues to straddle the gender line as his mental state remains fixed on his desire to reunite with the Lady, regardless of the fact that such a reunion would necessitate his own death and leave his realm in political turmoil. In my analyses of Middleton's and Chapman's plays, I argue that the ghosts' affect as memorial reinforcements of emotional connection between loved ones causes Clermont and Govanius to abandon conventional gender expectations, which are revealed to be limiting and inadequate to fully encompass the truth of the human condition, especially as it pertains to our feelings for those closest to us.

\subsection{The Ghost in Early Modern England and English Drama}

In his Study of Elizabethan Pneumatology, Robert West summarizes Reginald Scot's definition of veritable ghosts, or what Scot refers to in his Discoverie as "astral spirits of men" (500-510), as "the sou[s]l of dead $\mathrm{m}[\mathrm{e}] \mathrm{n}$ returned to earth", which comprised three elements: first, the spirit, "an intelligible essence transcending human sense", second "an image that represented itself in the fancy of a man", and finally "an exterior shape that gave rise to the image" (West 167). Scot's categorization highlights the psychological foundation in which the ghost is rooted - itself an "intelligible essence" that can communicate its existence only by anchoring itself in the imagination of another. In the same way, it is through the imagination that scholars like Bacon and Ficino, discussed in the previous chapter, theorized that human spirits could emotionally connect with, and influence, one another. However, the exterior shape of the ghost is just as dependant on the psychology of the one who encounters it; according to Alfred Roffe, early moderns believed that a person's moral nature could alter his/her exterior shape, as well as the "form" of their soul (8). This is supported by sixteenth-century writers like Noel 
Taillepied, who claimed that bad spirits tended to appear in dark vestments, with displeasing voices.

But what Scot's criteria also reveals is the inextricable link between the moral and the psychological inherent in the very nature of the ghost, which I discussed at the start of the previous chapter as well. While much of the scholarly material written in early modern England centered on the religious, and religious-historical, roles that ghosts play, twentieth-century critics have extended the discussion beyond the moral by exploring the psychological significance of ghosts, especially dramatic ghosts. Like some early modern pamphlet-writers, who frame ghost stories according to conventional socio-political or moral lessons, many modern scholars continue to invoke the moral implications of characters' psychology in their analyses of The Revenge of Bussy D'Ambois and The Second Maiden's Tragedy. However, conceiving of characters' psychological evolutions in principally moral terms inevitably results in critical limitations. For example, critics like Geoffrey Aggeler and Michael H. Higgins argue that Clermont embodies the Senecan Stoic, ${ }^{49}$ living by a code of virtue and justice which determines the way he avenges his brother, Bussy's, death, and even motivates his suicide. According to Aggeler, Clermont's eventual acceptance of the role of revenger comes not from love of his brother, but from the idea that the revenge is of "Great Necessity" (8), a part of God's plan that he must fulfill..$^{50}$ In a similar vein, Higgins argues that for Clermont, "suicide is the final act in a supremely logical existence" (191) — the best way for him to carry his Supreme Reason and faith

\footnotetext{
${ }^{49}$ The late Stoic philosophy of Seneca drew from ethical paradoxes, like good and bad, to determine the best way for a man to achieve happiness (A.MacDonald ii). According to Senecan Stoics, the wise man "aims at happiness, at calmness of soul, at fortitude of adversity, and at justness of conduct at all times" (v).

${ }^{50}$ On the battlefield, Clermont explicitly states his loyalty to God and His vision above all else; he preaches that when a man "confin[es]" his abilities to enact only his "proper part", then he is "most God-like" (III.iv.69, 71).The idea that everyone has their "proper part" supports Aggeler's claim that Clermont's focus is on fulfilling his role in God's plan.
} 
even into death (186). Higgins, however, problematically assumes Clermont is "free from irrational desires... and all other temptations of the external world, as also from doubts, reservations, fears and speculation coming from the inner mind and spirit" (189). The play provides evidence to the contrary, ${ }^{51}$ particularly in Clermont's relationship with the Duke of Guise, as it is for the love of Guise that Clermont eventually sheds his Stoic armour.

Both Suzanne F. Kistler and Allen Bergson recognize that Clermont's love for the Guise proves irreconcilable with his philosophical outlook; thus, the play exhibits the failure of the Stoic to attain a world of virtue. Even as Kistler notes that for Stoics, "friendship among virtuous men was prized", she also acknowledges an "emotional dependence" between Clermont and the Guise which far exceeds the bounds of Stoic philosophy (138). ${ }^{52}$ Bergson agrees, stating that Clermont's "love for the Guise is the most powerful threat to his Stoic otherworldliness" (50). Kistler and Bergson also challenge the conservative explanation Aggeler and Higgins offer for Clermont's suicide. Bergson, in particular, observes that the figurative language Clermont uses in his final speech transforms the act into an expression of worldly love and dependence (50), rather than a rejection of it. Indeed, Clermont's language is passionate, hyperbolic, and romantic even, in a way the audience has witnessed only minimally in his character. He refers to the Guise as he "that alone gave means of life to me" and determines that he, Clermont, "end[s] with him [Guise]" (V.v.150, 156). His diction hints at the desperation of a lover left behind, who refuses to allow death to part him from his beloved. As such, it is the ghost of Guise, the visual

\footnotetext{
${ }^{51}$ During one of the few moments that the audience finds Clermont alone, he exposes a vulnerability in his Stoic armour when he notes how he actively buries his passions in order to assume a Stoic guise, the decrees which, he admits, "I every day set down to guide my life" (III.iv.13). The fact that the decrees must be "set down", "every day" indicates that they are neither necessarily as natural as his passionate disposition, nor are they secure enough to stand against that passionate nature without constant reiterance.

${ }^{52}$ In his article, "The Tragedy of Clermont D'Ambois", Alexander Leggatt similarly argues that Clermont exhibits "a remarkable emotional attachment" to the Guise (531), so much so that Clermont "destroys himself for the sake of the friendship he has made the centre of his life" (535).
} 
manifestation and first indication to Clermont of his friend's death, which sends Clermont into an irrecoverable emotional frenzy. The ghost of the Guise is likely overlooked by most scholars because of its brief appearance: just one apparition among a parade of others dancing around the body of the dead Montsurrey. Like the ghosts of the Cardinal and Monsieur in this scene, the Guise's ghost does not speak - there is not even any indication that it pays particular attention to Clermont. However, scholars have omitted the significance of the fact that Clermont sees the ghost of the Guise, and the subsequent realization of the death of his friend is what pushes Clermont outside the boundaries of Stoic virtue and reason altogether. Aggeler notes that after learning of the Duke's death, Clermont immediately rejects the idea of revenge (13), and this is indeed significant, though not necessarily for the reasons Aggeler claims. As Higgins notes previously, even revenge can be rationalized according to God's will; suicide, however, was explicitly condemned by the Church in Chapman's day (Martin 117). Nonetheless, Clermont's final concern is not with spiritual virtue, but with earthly love, and it is the Guise's death, specifically the visual manifestation of his dead spirit, which moves Clermont to the passionate response that he was unable to muster for his brother.

As with Clermont, in the Second Maiden's Tragedy, Middleton's Govanius is moved to action only after the one he loves has been killed, and her death visually manifested through the return of her spirit. However, the actions occur somewhat inversely, as Clermont transitions from a point of excessive reason and spirituality, to completely succumbing to his worldly and bodily passions, while Govanius first seems entrenched in his own psychological distress, and gradually emerges from his own self-concern towards a concern for doing what is right by his Lady, at least long enough to redeem his previous failure to act. In his chapter, "Spiritual Freedom vs. Corporeal Bondage", A.L Kistner discusses the role of the mind in Middleton's play. He claims 
that, in Middleton, "the mind...can be a tormentor as easily as it can be a pacifier" (56), and this becomes especially pertinent to the psychological conflict Govanius undergoes. However, Kistner identifies the mind as a unifying theme in Middleton's drama; I would argue that it actually represents a key duality between Govanius' own, conflicted psychology and the pull towards morality and transcendent spirituality which the Lady's ghost represents. Kistner, I think accurately, observes that the Lady uses "mind" to indicate "moral disposition" (51) and, particularly because of her own moral purity, also becomes associated with the spirit. Anne Lancashire claims that Govanius and the Lady are aligned through their virtue (qtd. in Middleton 36); thus, the Lady believes that Govanius' virtuous "mind” guides him towards moral intention and action, even as her spirit effectually provides the "authority and guidance" (Johnson 110) that prevents him from succumbing to his overwhelming sorrow.

However, Lancashire's assertion that Govanius is primarily associated with the virtue of the spirit, a "defender of public right" (38), overlooks the fact that morality is not necessarily his principle motivator, and that several times throughout the play Govanius struggles between the voice of conscience and that of desire. Even as Kistner argues that Govanius experiences a "freedom from care...now that his moral obligation is fulfilled" (53) - the body is restored to its resting place and the Tyrant is dead-his "moral conduct" (52) does not resolve his psychological struggle. Rather than experiencing any sort of spiritual transcendence or attaining any higher virtue akin to Clermont's Stoic exemplars, Govanius' moral restoration is overshadowed by his desire to join his beloved Lady in death. Indeed, it is as much this desire that drives his action as his sense of obligation to the Lady and her spirit; he knows he can only "make [him]self / over to death" so they might "walk together" once he has achieved the task the spirit has set for him (IV.iv.81-82). And once the deed is done, he exhales, "now, death I'm for 
thee: welcome!" (V.ii.167) However, Govanius is made to wait to be reunited with his lady, as the Tyrant's overthrow allows him to be reinstated to his usurped throne, even as Govanius admits that this restoration was "never looked for" (V.ii.185). Govanius, therefore, does not achieve the release through death that Clermont forces.

Both Clermont and Govanius undergo an internal struggle between doing what is right and surrendering to their desires. Regardless of the fact that Clermont's struggle is shorter lived, or that Govanius ultimately takes on the role expected of him, those struggles nonetheless reveal the multi-faceted elements of their interiorities which prevent them from strictly adhering to the social codes of one gender over the other. Clermont's suicide is a result of the overwhelming emotion he feels at realizing the truth of his friend's demise, though his impulsive action stands in stark opposition to the rational judgement and courtly conduct he exhibits until the moment the ghost appears. Govanius' selfish desire to prevent his own suffering culminates in a weakness of resolve which forces the Lady to die by her own hand; however, the return of her spirit prompts him to demonstrate the conviction of action that he lacked previously, while he nonetheless continues to nurse his desire to forsake the living world and reunite with the Lady in death. In both instances, an exploration into the characters' psychologies unearths a blurring between male and female criteria, and a reimagining of what it means, not only to be a man, but a man capable of soul-shattering love. Like Hamlet and Antonio, Clermont's and Govanius' psychological reactions to the ghosts of their loved ones results in a rejection of traditional masculine ideals which challenges contemporary expectations for certain social relationships. In the sections that follow, I will analyze two seventeenth-century ghost encounters in order to assess how the sentiments of these pamphlets highlight the unconventional psychological journeys Clermont and Govanius undergo when they encounter the ghosts of those they love. My 
aim is to demonstrate that when analyzed alongside these pamphlets, it becomes evident that Middleton and Chapman use their ghosts to resist early modern notions of masculinity, and to critique the emotional limitations associated with contemporary expectations of maleness.

\subsection{The Lady's Ghost}

In 1643, Henry Lovel returned to his London abode after spending time looking at real estate in Ireland. ${ }^{53}$ Upon his return, he penned a pamphlet about a strange experience he had during his time abroad. ${ }^{54}$ Travelling into Munster with a friend (who Andrew Tierney tells us was likely Sir Donough MacCarthy, heir to Blarney Castle), ${ }^{55}$ Lovel recalls arriving at "a castle of one of the FitzGarrets"-Ballymartyr Castle, now Castlemartyr, formerly the household seat of the FitzGerald family (Tierney 9). Over the subsequent few nights, Lovel mentions a series of bizarre events involving spirits, which MacCarthy had previously told him haunted the castle (1). First, there were "such damnable noises", and then "forms...thrown....at [our] heads", and tables were moved across the room by invisible forces, "for a combined three houres" (2). The following night, Lovel recalls a spirit that stole his blanket from him; Lovel describes engaging in a tug-of-war with the spirit, all the while thinking, "if he [the spirit] continue to pull thus divelishly, he will tyer me out quite" (2).

There are a number of other spirits that Lovel mentions in his account: one appeared in white near the window, and "raised himselfe up to the height of the window, and grew big in the upper parts and slender below... and sometimes he would sinke down to his former posture, and

\footnotetext{
${ }^{53}$ This account is taken from Henry Lovel's pamphlet, entitled Horrid and strange news from Ireland: being a true relation of what happened in the province of Munster, at a castle of one of the FitzGarrets, called Ballimarter, wherein there were very strange apparitions, the like never before heard of, to the amazement of all the beholders, printed by Thomas Harper, 1643, Wing / L3236, EEBO.

${ }^{54}$ Tierney estimates that it was likely the events in the pamphlet took place not long before the Irish Catholic rebellion of 1641, which started in October of that year. The events likely occurred the summer prior (12).

${ }^{55}$ See Tierney's article "Return of the Repressed? "Haunted Castles" in Seventeenth-Century Munster," EireIreland, vol. 45 no. 3/4, 2010.
} 
up again with a body like a Gyant" (4). This spirit carried with him random body parts, and

Lovel recalls him tossing the head of a youth, whose face was "long, lean and hollow-eyed", into the air and catching it again (4). Lovel attempts to launch himself at the spirit, but he vanishes. Soon afterwards, he hears screams and cries coming from the servants' quarters upstairs, so he "came in to helpe them", though he admits that in his act of heroism, he never actually remembered the servants, "meaning to lay indifferently among them" (6). Once the spirits exit the room, Lovel returns to his own room. The next time he heard people being thrown about upstairs, he merely recalls "being glad I had no more hurt among them [the spirits]" (7). He departed with MacCarthy from the castle the next morning.

Overall, the pamphlet appears to lack the overarching moral frameworks seen in some of the other ghost accounts from the period. ${ }^{56}$ Unlike the Edge-hill ghosts or the ghost of the gentleman discussed in the previous chapter, the Ballymartyr ghosts do not seem to recall any particular memory of loss or wrongdoing, nor do they appear in search of revenge or absolution. Rather, Lovel describes the Ballymartyr ghosts as trivial, even petty. The ghosts are introduced through their material associations, ${ }^{57}$ and their place in the tale comes to resemble the banality of

\footnotetext{
${ }^{56}$ In his overview of the encounter, Tierney suggests that the account may have been written as anti-Catholic propaganda, given that both the FitzGeralds and the MacCarthys were prominent Catholic influences in Ireland-he speculates that the entire ghost spectacle was a contrived ruse put on by Lovel's hosts to promote their own beliefs in the afterlife, purgatory, etc. This possibility does explain the relatively minimal focus the pamphlet puts on the ghosts themselves - Lovel never wonders who the spirits might have been, or why they have chosen, or been forced, to remain at Ballymartyr. Rather, they are supporting actors in a story that puts Lovel himself at the centre. By exiling the spirits to the background, Lovel minimizes the importance of the ghosts, and so underplays the very elements that Catholics would want emphasized in order to credit their own beliefs. Despite this hypothesis, Tierney also recognizes that the pamphlet lacks many of the "hallmarks of anti-Catholic propaganda" (11), and notes that in Lovel's account, MacCarthy seems to be as genuinely surprised by the apparitions as Lovel himself: thereby discrediting the idea that he may have helped contrive the entire affair (12). Moreover, Lovel himself never implies that he believes the spirits he encounters to be inauthentic. He even attempts to combat them using God's name- $\mathrm{a}$ tactic which was thought to drive out devilish illusions, and so separate ghosts proper from spirits sent by the devil (Lavater 108, 202). Evidently, Lovel believes that the figures he encounters are, in fact, supernatural; yet, neither his descriptions of the spirits nor his reaction to them harken back to conventional tropes of seventeenth-century ghost stories.

${ }^{57}$ The first one makes himself known by pulling Lovel's friend out of his bed by the leg, and the ones that follow are acknowledged because of the items they throw at the castle lodgers.
} 
the objects they move. For, they vanish as soon as they are rid of their household weapons — as soon as Lovel is able to wrestle his blanket, and then his boot from one spirit, that spirit disappears from the narration and the author's focus shifts to the next immediate apparition (3). Lovel's triumph over the parade of spirits requires little more than strength to win various bouts of tug-and-war (2) and speed enough to dodge the objects hurled across the room at him. Even the one spirit who enters with the semblance of extraordinary force-appearing with "a whip of lightening... a shape of a body fifteen or sixteen foot of length...[whose] head reached the roof of the chamber" (5) — is soon deflated by Lovel's own sense of superiority. He observes the giant had "a sorrowfull countenance" which Lovel assumes is because the spirit "thought himself an unequal match to grapple with him [Lovel]" (6). Evidently, Lovel is unfazed by his supernatural encounter, as he describes the supernatural apparitions as little more than recreational combatants which he defeats with ease, even pleasure. This figuration of the ghosts nonetheless suits what seems to be Lovel's larger aim; by diminishing the threat of the ghosts, Lovel makes himself appear the more powerful, intimidating being. The supernatural becomes a tool for selfpropaganda wherein Lovel, despite his mortality, holds the manifestations of death at bay. They have no sway over him, largely because, I argue, they do not possess the psychological depth of the ghosts of Old Hamlet or Andrugio, nor of the Lady's spirit in Middleton's tragedy. Lovel's narration exudes a kind of socio-political agenda that serves to highlight his own embodiment of the masculine ideals of his day; Middleton, by contrast, uses the Lady's ghost in the Second Maiden's Tragedy to re-evaluate the truth behind such gendered ideals, and to explore the underlying frailty of a socio-political hierarchy which relies on exclusive codes of gendered behaviour that do not accurately account for the multiple facets of the human condition. 


\section{The Memory of a Maiden}

Like the Ballymartyr apparitions, the entrance of the Lady's ghost acutely reflects the impact she will have on Middleton's play, on the psychology of Govanius in particular. Unlike the Ballymartyr apparitions, the Lady's ghost arrives in a dramatic whirlwind of light and sound. The text's stage directions indicate, "on a sudden in a kind of noise like a wind, the doors clattering, the tombstone flies open, and a great light appears in the midst of the tomb; his Lady, as went out, standing just before him in all white, stuck with jewels and a great crucifix on her breast" (IV.iv.42.1-42.42.6). The image of the sepulchre being overcome by the force of the emerging spirit signals the strength of the presence of the Lady's ghost. Dressed in white with a crucifix and bejeweled, the spirit is both divine ${ }^{58}$ and regal, and she, unlike Lovel's ghosts, will not be easily dismissed. The spirit's commanding entrance is a fitting metonym for the degree of influence the Lady's ghost holds over Govanius' mind throughout the rest of the play. It is fitting that her spirit should have such malleable influence on Govanius' psychology, since, A.L Kistner also notes (50-51), the Lady is often associated with the mind and the spirit even before her death. Indeed the first line she speaks in the play is "I am not to be altered", and the second is "I have a mind" (I.i.123-24). She also insists on choosing her mate by quality of his virtue, his spirit, his very essence, rather than by what titles or good he might have: "'Tis not the reeling fortune of great state / ...I cast mine eyes at / It is the man I seek... / It is the mind that sets his master forth" (I.i.173-75, 178). Middleton makes her the epitome of steadfast truth, reason and intellect, directly contradicting stereotypes of the fickle, materialistic woman; the Tyrant indicates as much when he remarks "there stands the first / of all her kind that ever refused

\footnotetext{
${ }^{58}$ Before the spirit visually appears, Govanius' hears her voice say "I am not here" (IV.iv.40). Julia Briggs notes the parallel between this scene and the resurrection of Christ, wherein angels clothed in white (similarly to how the Lady's spirit also appears) tell the astounded women that Christ's body "is not here, for He has risen" (Middleton, N.40, p. 890). The Lady's ghost seems divine in her parallels to both the angels and Christ himself.
} 
greatness" (I.i.182-83). By emphasizing the Lady's connection to the mind and the spirit from the beginning, Middleton foreshadows the affective power of the Lady's ghost by defining her living person according to contemporary understanding of the ghost's primary ontological characteristic - the rational soul. In so doing, Middleton creates the Lady's ghost as a true representation of the Platonic soul, touted by Aquinas, Ficino and other such scholarly influences on Renaissance thinking as the principle essence of the living person, though possessing more significant spiritual and intellectual potency outside of the confines of the body.

\section{A Failure of Masculine Proportion}

While the ghost's ability to influence Govanius would be understood by early moderns to stem from her intellectual/spiritual ontology, the ghost's affective power is specifically drawn from her memorial significance for Govanius, and so the resultant affectual ties are rooted in the recollection of feelings and experiences shared between former lovers. However, the ghost recalls both the intimate love the Lady shared with Govanius when she was alive, which Govanius has retained despite her death, and, simultaneously, Govanius' failure to do right by the Lady in the last moments of her life. ${ }^{59}$ When the Lady needs Govanius to undertake a difficult task that is yet necessary to prevent her own disastrous fate, Govanius is concerned only with his own psychological dilemma. When she asks him to kill her to prevent her being taken, and likely violated, by the Tyrant, Govanius falters, crying "must I meet peace in thy destruction? / ... / I had rather be content to live without it / than pay so dear for it" (III.82, 8586). Govanius forgets that the death in question is the Lady's, not his own, and yet he victimizes himself: "must I pay so dear", "I had rather be content". Even when the Lady insists "the sufferer should not do't' (III.91) — reiterating that she, not he, is the true sufferer here-Govanius

\footnotetext{
${ }^{59}$ Sarah Johnson makes a similar observation, p. 127.
} 
manipulates the situation, where the most dire consequences await the Lady, in order to emphasize his own sorrow, his own pain.

By refusing to help her die, Govanius proves that he would rather spare himself the difficulty of killing his lady than prevent her from being raped by another man. His lack of conviction disappoints her, as he swoons when he hears the Tyrant's guards at the door, and she laments, "did I trust to thee / And hast thou served me so?" (III.150-51). The fact is, that Govanius has not served his lady, but, instead, has left her either to do the deed herself, or face abuse and humiliation. He has betrayed the Lady, but he has also betrayed his own honour by refusing to help her save hers (nor does he attempt to kill the Tyrant to prevent her from having to act at all). Raymond Rice notes that according to the cultural logic of early modern revenge tragedy, 'morality is always gendered: women can never stand 'firm' but are always 'rising' to virtue or 'falling' into vice" (302). By swooning in the face of a difficult task, which would nonetheless help to preserve the Lady's virtue, Govanius literally falls from the masculine stereotype, leaving her to pick up the sword and to stand as the "resolute lady" (III.159). ${ }^{60}$ Therefore, in the early modern social atmosphere — where, as Rice articulates, "the female body...must haunt the margins of the male community because it is against their [women's] excessive appetite that the male community authorizes itself as 'proper"' (303)—Govanius' overwrought emotion and his irrational desire to covet the Lady, despite the danger it posed to her, serve to delegitimize conventionally "proper" male conduct because it is he who embodies the weakness expected from the opposite sex.

Here, Govanius enters into what Susan Amussen refers to as "the upside down world" of gender inversion in early modern England, wherein some people refused to behave according to

\footnotetext{
${ }^{60}$ See Sarah Johnson's discussion on gender reversals in The Lady's Tragedy in chapter two of her book, cited in bibliography.
} 
normative gender practices; Amussen notes that such inversion, especially in men, was often blamed on the failure of the patriarchy to promote traditional masculinity (Gender, Culture, and Politics, 19). The result of this recurrence of "upside down" behaviour was that social and political authorities became more adamant about people demonstrating traditional gender values, to the extent of publically humiliating those families where the gender roles appeared to be explicitly violated (in the case of a weak or meek patriarch, for example) (Amussen Gender 20). But being exposed to the consequences of his weakness does not necessarily turn Govanius onto more traditionally masculine behaviour, nor does his focus on his own suffering immediately subside once he recovers from his fit and discovers that the Lady has killed herself. Granted, he does chide himself for his shameful behaviour, admitting to being "hard" and "respectless" (170), and "fain" (174). However, he continues to regard her sacrifice as "a triumph to $m e$ " (III.213, emphasis mine), claiming a kind of victory over an act which he refused to perform. He also laments her death largely because "her life was so sweet to me" (235); again, he considers her life and her suffering only in terms of himself, never considering what having to sacrifice her own life must have meant for the Lady. His self-centered psychology only begins to shift perspective after he encounters the Lady's ghost.

The first words the spirit speaks to Govanius encapsulate the dual nature of the ghost's memorial significance: "Dear lord, I come to tell you all my wrongs" (IV.iv.54). By addressing him as "lord", the Lady's spirit reminds Govanius of his gendered role in their romantic relationship. The word "lord" connotes his elevated position in the male-female hierarchy and, as such, reflects his responsibility to the Lady as her protector, defender, the one to whom she subverted herself and on whom she depended. However, in a kind of reverse confession, the Lady's spirit recalls the taint that Govanius has brought upon that role by failing to fulfill these 
responsibilities. Although the ghost says, "I come to tell you all my wrongs", it proceeds to tell Govanius of the gross violation of its body, removed by the Tyrant from its resting place. Despite the apparent confessional rhetoric, the spirit really means to tell Govanius of the wrongs done to the Lady. But Govanius is the first offender, as even before the Tyrant's heinous act, it is Govanius who fails his Lady by refusing to give her an honourable death. Thus, when the spirit comes to speak of wrongdoing, it is Govanius' failing as a lord and a lover that it foremost recalls.

Govanius' reaction to the spirit is telling of his shame in his inability to perform his duty to the Lady when she was alive. His initial response is fearful, as he invokes divine protection from the spirit: "Mercy, look to me! Faith, I fly to thee!" (IV.iv.43) Here, Govanius' reaction to the ghost is much as one might expect: encountering the spirit of his dead beloved shocks and terrifies him to the point where, unable to help himself, he calls on the highest powers for assistance. Moreover, his select invocation draws intriguing parallels to the pleas the Lady makes when asking him to save her from ravishment. Just as Govanius now asks for "mercy", so the Lady begged that he would not allow her to be "taken / And lost the cruel'st way" (III.77-79). Govanius, however, could not forgo his own covetous love to save the Lady from an awful fate. Thereafter, Govanius "flies to faith" too late, as he should have committed himself to such steadfast belief when the Lady, to assure him of the spiritual eternity of their love, asserts "His [the Tyrant's] lust may part me from thee, but death, never; / Thou canst not lose me there, for, dying thine, / Thou dost enjoy me still" (III.iii.144-46). But Govanius finds no comfort in the Lady's words, nor does he demonstrate belief in the strength of their bond beyond death, because he continues to refuse to kill the Lady - evidently willing to chance separation by way of the Tyrant's lust before parting in death. By immediately invoking mercy's protection and faith's 
guidance, Govanius' own words reveal the reason for his fearful reaction to the ghost - his own inability to bestow such virtues upon the Lady before her death. Because of his failure, the Lady's words take on an alternative significance. Where "dying thine" should signals the Lady committing herself to him in spirit, his inability to relieve her of future suffering taints the sentiment; indeed she does die his_- his responsibility. The Lady's ghost makes as much evident when she tasks Govanius with recovering her body: "my rest is lost; thou must restore't again" (IV.iv.79). He must restore the body, and in doing so protect it from the Tyrant's grotesque obsession, because he failed to protect her the first time duty demanded it. The ghost appears to Govanius both because of their spiritual connection, and because he needs to redeem himself for the previous slight against the Lady and her honour, which the presence of the ghost itself recalls.

Love in the time of Death

Govanius' immediate fearful response to the ghost is much more conventional than Lovel's. Not once does Lovel express even a semblance of fear or anxiety when he encounters multiple spirits at Ballymartyr castle. Rather, he seems to consider them little more than a nuisance; after hearing such "damnable noise" in the hall from spirits tormenting servants, he recalls thinking, "we are like to have a pretty night of this... as we cannot be suffered to goe into the Hall" (2). He is not nearly as concerned with the supernatural activity occurring as he is with the possibility that the mischievous spirits might interfere with his own nighttime routine. When he confronts the spirits, he treats his combatants as inconsequential foes. He describes his battle for a boot with one of the spirits, boldly asserting he would "teare it in pieces before he [the spirit] shall pull the boot from me" (3). Lovel never seems to register the oddity of his situation, and acts as though he is regularly accustomed to such supernatural encounters. This is evident in 
his constant readiness for each different spirit, and in how methodically he seems to react to them, as though he knows exactly how to handle these altogether bizarre and extraordinary circumstances. When a spirit appears near the window, playing with what seems to be a severed human head, Lovel is quick to "thrust [his] hand to his [the spirit's] throat" (4). At one point, he describes himself as "laugh[ing] at the roguery" of the spirits' tricks, calling them "sport" (3). Throughout his retelling, Lovel always positions himself as the superior being; despite their supernatural status, the haunting spirits are weak presences that Lovel can dismiss by exerting his masculine strength and wit. Govanius, however, has no such control over the Lady's spirit; rather he utterly succumbs to the spirit's will, forgoing any such shows of strength or bold confrontation as Lovel claims to exhibit.

The principle difference between the two encounters seems to be the relation between the male protagonist and the spirit he encounters. Lovel appears to have no prior connection to the spirits he encounters; they are not denoted by name, only by description, and this detachment likely permits him to engage so roughly with them. But Govanius is deeply invested in the apparition of the Lady's spirit, largely because it reminds him of his inability to fulfill the Lady's expectations of him as a man who would be strong enough, both physically and mentally, to put her well-being ahead of his own desires. It is his initial incapacity to embody these masculine ideals that again places him in a traditionally feminine position: he becomes subservient to the Lady's spirit partly because he must redeem himself for his prior weakness. But his subservience is twofold, both obligatory in the debt of honour he owes the Lady, and voluntary, as his emotional attachment nonetheless continues to play a significance role in his reaction to the ghost. For after he overcomes his initial terror, Govanius revels in the idea that he may now, as the Lady herself predicted, "enjoy [her] still”: 
$\mathrm{O}$, never came astonishment and fear

So pleasing to mankind! I take delight

To have my breast shake and my hair stand stiff.

If this be horror, let it never die!

Came all the pains of hell in that shape to me,

I should endure'em smiling. Keep me still

In terror, I beseech thee. I'd not change

This fever for felicity of man

Or all the pleasures of ten thousand ages. (IV.iv.45-54)

Here, Govanius seems almost hysterical—yet another condition traditionally attributed to

women. Yet, his rhetoric is indicative of the ghost's dual affect: he entwines the consistent horror of the presence of the supernatural, and his fear of recalling the shameful ineptitude which the spirit memorializes, with professions of love and happiness reminiscent of his earthly bond with the Lady, which evidently transcends the mortal cage. He acknowledges that while his "breast shake and [his] hair stand stiff" and he is yet "still in terror", he finds the feeling pleasing, delightful, and, thus, would not trade his physical and mental disturbance if it meant that he would lose sight of the Lady's image. By claiming he could endure "all the pains of hell" if they appeared "in [her] shape", Govanius implies that the visual manifestation of the Lady triggers painful memories in him—recollections both of her own death and the regretful manner in which they parted. His horror mixed with his joy at seeing the image of the Lady again, even if just her spirit, pulls Govanius' initial reaction out of the realm of the conventional and into an altogether indecipherable and unexpected sphere. He becomes as enamoured with the spirit as he was with the Lady when she lived, and so he embraces the fear that accompanies his ghostly interaction. Here, Govanius starkly opposes Lovel, who feels neither fear nor attachment to the spirits he encounters and, as a result, is able to vanquish them and so emerge the superior being. But Govanius forsakes gender ideals in favour of languishing in the dual lure of the ghost's affective power. He embraces both the love and the fear that the spirit emanates, unwilling to sacrifice one 
at the expense of the other, as both are equally vital to maintaining the post-mortem connection between the lord and his lady.

Govanius' reaction to the Lady's ghost becomes even more complicated once the ghost vanishes after their initial meeting. For as much as his fear of the ghost fuels his pursuit of redemption by restoring the Lady's body, Govanius makes clear that re-obtaining the Lady's body is an obstacle he must overcome in order to achieve his true end: death, and in death, reunion with the Lady. His initial contemplation is not about how to rescue the Lady's corpse from the Tyrant, but about how to reunite his spirit with hers: "I'll make myself / over to death, too, and we'll walk together" (IV.iv.81-82). However, after realizing that his personal longings are taking time and attention away from serving his lady, he concedes, "I must dispatch this business upon earth / Before I take that journey" (IV.iv.86). Returning her body to its resting place is, thus, both an obstacle to and a condition for his final reunion with her. Once Govanius retrieves the corpse and kills the Tyrant, his thoughts return to his primary desire, as he rejoices, “now, death, I'm for thee: welcome!" (V.ii.167) This is Govanius' second notable use of the word "welcome"; the first instance occurs when he sees the ghost and he enters into his pseudohysteria. His similar reception of death at the end indicates a parallel trepidatious excitement at the prospect of meeting the Lady's spirit again, even if it means his own death. But Govanius' embrace of death is not necessarily native to his character, as his opinion on the matter changes significantly when he witnesses his brother, Anselmus', death, immediately following the death of his own wife. Govanius laments:

Is death so long a-coming to mankind It must be met half ways? Las, the full time Is (to eternity) but a minute, Was that so long to stay? O cruel speed!

...What strange haste

Was made among these people! My heart weeps for't (V.i.181-89). 
His rhetoric here starkly contradicts his previous contemplation on death. Where he yearns for his own death only a few scenes prior, here he expresses regret that his brother would hasten towards his death. Anselmus dies fighting a man who, he thought, slandered his wife's honour by falsely accusing her of adultery (the Wife, Anselmus later discovers, was, in fact, unfaithful) (V.i.125-180). The irony is that Govanius cannot seem to understand why Anselmus would risk a premature death, despite the fact that Anselmus, like Govanius, does so for the woman he loves. And less than ten lines after lamenting his brother's untimely demise, Govanius reiterates his own desire to remain in the presence of death: "I desire to have it [the ghost] haunt me still / And never to give over, 'tis so pleasing” (V.i.197-98). Evidently, Govanius' emotional attachment to the ghost is what specifically influences his desire to die, whereas when he is free of the immediacy of the ghost's affect, his own feelings towards death are more conventionally rational and, thus, more characteristically masculine.

\section{Feel it like a Man}

That is not to say, however, that the ghost's emotional affect and memorial significance render Govanius strictly effeminate. Rather, the gender implications of his psychological response to the ghost are complex, yet that complexity blurs traditional gender boundaries. In his criticism of Anselmus' death, Govanius laments the impatience of the act and his regretful tone suggests that he views a kind of weak constitution in his brother's inability to bear out his hardships in the situation with his wife. Impatience, especially, shows a lack of reasoning, reflecting an impulsivity which the early moderns tended to attribute to females, being the 'weaker sex'. But Govanius himself wishes for the same swiftness of death several times throughout the second half of the play, particularly when the ghost is present and he is overcome by his love for her. In this way, the spirit of the Lady, as the Lady did herself when she was 
alive, exerts a kind of feminine influence on Govanius where he acquires stereotypically womanish qualities like impatience, excessive emotion and weakness of constitution. But, Middleton complicates these contemporary gender ideas, because "effeminacy" in his play takes on another connotation from the start. It is, after all, the Lady who is associated with the mind and the spirit, and it is she who demonstrates strength and resolution when she opts for death for the sake of her honour. And just as she exudes such masculine qualities, so her spirit infiltrates Govanius' psychology with them as well. Only after he encounters the Lady's ghost is he able to act on its behalf instead of bemoaning his own loss - though, he does so using poison (V.ii.125), traditionally known as a woman's weapon. Therefore, Govanius is not necessarily effeminized by the influence of the ghost; he is simultaneously prompted to fulfill the masculine ideals that he himself previously cast off.

His interaction with the ghost, and its affective influence on his thoughts and actions, result in variant gender incongruities that both adhere to and challenge conventional feminine and masculine stereotypes. It is this ambiguity that shatters seventeenth century ideas about what it means to be a man or a woman. But, perhaps the most significant implication of the ghost's influence on Govanius' gender identification occurs at the end of the play, when he is given the chance to take up his rightful place as king. While he seems grateful to be restored to his position $^{61}$, Govanius nonetheless rejects the full responsibility of being king. He claims that the Lady's body should be crowned as queen, "the first and last that ever we make ours" (V.ii.201).

\footnotetext{
${ }^{61} \mathrm{He}$ welcomes the nobles who come to acknowledge his rightful kingship, claiming "I'm like a man plucked up from many waters / That never looked for help, and am placed / Upon this cheerful mountain where prosperity / Shoots forth her richest beam" (V.ii.183-86). His use of positive analogies, as a man "plucked up" to a position that is "cheerful" and "rich" indicates that he is happy about his restoration. The passive imagery inherent in his language - he is "plucked up" by others, not of his own doing — reinforces the blurring of the gender roles that continues unto the very end of the play. For even when Govanius is restored to his political position, he plays no active part in that restoration, but rather remains a passive subject - passivity being among the qualities expected of a woman.
} 
By refusing to take a living bride, and so produce heirs to continue his family line, Govanius' declaration is a direct challenge to the same rule of patriarchy that he takes up at the end of the play. Sarah Outterson-Murphy claims that Govanius' decision to remain faithful to the Lady is a sign of his firmness - a constancy that he promises in order to emulate the Lady's own moral constancy (153). However, Govanius never specifies that it is her moral constancy in particular that he admires in the Lady; he simply states "her constancy strikes so much firmness in us" (V.ii.202). The principle "firmness" the Lady shows is in her resolution to escape being stolen by another man, and so she overcomes her own trepidations and fears to demonstrate a strength that is more conventionally male than female. Her spirit then affects Govanius with this same firmness - to remain as faithful to her as she showed willing to be to him. The irony, is that this newfound resolution which the Lady and her spirit infect Govanius prompts him to simultaneously embrace and reject his patriarchal position — taking up the mantle but refusing the full scope of its responsibility. While Lovel's ghosts serve to emphasize the potency of his effervescent maleness, Middleton's ghost upsets normalized visions of gender by prompting Govanius to occupy a space in between — neither wholly effeminate nor conventionally masculine, neither outside patriarchal norms nor fully invested in them. Govanius' complicated relationship with the Lady's ghost suggests that perhaps the "upside down world" Amussen cites is not that of gender inversion; perhaps, more accurately, it is the society that narrows its conception of ideal masculinity to such an extent that a man is dissuaded from showing, feeling, and experiencing his humanity.

\subsection{The Ghost of the Guise}

In April 1690, William Barwick took his pregnant wife to a local pond, and drowned her. Thinking to cover up his crime, he told his brother-in-law, Thomas Lofthouse, who was married to his wife's sister, that he had “carried his Wife to one Richard Harrison's House in Selby, who 
was his Unkle, and would take care of her." ${ }^{2}$ Barwick's lie, however, would not stand, as the following Tuesday, the ghost of his dead wife appeared to her brother-in-law. Lofthouse was watering his hedges, and "as he was going for a Second Pail-full [of water], an Apparition went before him in the Shape of a Woman, and soon after [she] sat down upon a Rising Green GrassPlat." At first, Lofthouse merely walked by, thinking nothing out of the ordinary, though upon a second glance he realized the woman remained still in the same position, "and that she seemed to Dandle something in her Lap that look'd like a White-Bag" which he had not noticed previously. After he finished his task, he stood from his yard to see if the woman was still there, but found that "she was vanish'd."

However, according to the author of the pamphlet, the strange occurrence "it seems [] made so little Impression in Lofthouse's mind, that he thought no more of it...till the same Night as he was at his Family Duty of Prayer, that the Apparition return'd again to his thoughts, and discompos'd his Devotion." At that point, he revealed to his wife what he had seen-that the woman was "habited in a Brown colour'd Petticoat, wastecoat and a white Hood, such a one as his Wifes Sister usually wore, and that her Countenance look'd extream Pale and Wan...and that her Physiognomy was like to that of his Wifes Sister." Mrs. Lofthouse "laying Circumstances together immediately inferr'd that her Sister was either Drown'd, or otherwise Murder'd." Prompted by this realization, Lofthouse investigated Barwick's story about leaving his wife in Selby, and finding it to be a lie, "which notable Circumstance, together with that other of the Apparition increas'd his suspicions to that degree, that now concluding his Wifes Sister was Murdered, he went to the Lord Mayor of York and...got Barwick apprehended."

\footnotetext{
62 This story comes from the anonymous pamphlet entitled, A full and true relation of the examination and confession of W. Barwick and E. Mangall, of two horrid murders one committed by William Barwick upon his wife being with child, near Cawood in Yorkshire, upon the 14th. of April last: as likewise a full account how it came to be discovered by an apparition of the person murder'd, printed London, 1690, Wing / F2322, EEBO.
} 
Like the 1678 pamphlet about the Gentleman and the Kinsman, which I analyzed in the previous chapter, this anonymous pamphlet from 1690 takes the middle road among widely variant early modern beliefs about ghosts. Where some scholars denied the existence of ghosts altogether, and others conceded that it was, in fact, possible for souls of the dead to return to earth, this pamphlet's author claims that the ghost is indeed the veritable soul of Barwick's wife, but sent from God with divine purpose. At the start of the pamphlet, the author writes that because murder "is one of the greatest Crimes man can be guilty of", it is often "strangely and providentially discovered." The author continues that even "when Witnesses are wanting of the Fact, the very Ghost of the Murdered-Parties cannot rest quiet in their Graves, till they have made the Detection themselves" (2). Most explicitly, he states that of Barwick's false story, "Heaven would not be so deluded, but rais'd Up the Ghost of the Murder'd Woman to make the Discovery" (3). Like in the case of the Gentleman, the ghost of the woman becomes a vessel for divine justice, wherein the apparition contributes to the revelation of moral truth. Lofthouse himself admits that the apparition largely increases his suspicions about the state of his sister-inlaw's well-being, which eventually lead to Barwick's arrest. The author of the pamphlet positions the story within the conventional bounds of religious morality, using the ghost as an example of supernatural surveillance, by which no ill deed goes unnoticed or unpunished. Although the author takes a somewhat controversial stance by supporting the authenticity of the ghost as the soul of the woman returned to earth, ${ }^{63}$ he does so in order to reaffirm accepted moral standards of contemporary English society.

Somewhat inversely, in the Revenge of Bussy D'Ambois, Chapman aligns Clermont with Stoic morality in order to uproot sixteenth-century moral and social customs. He achieves this

\footnotetext{
${ }^{63}$ Some scholars suggest that this increasing treatment of ghosts as authentic souls sent from God was a response to the increasing threat of atheism in England at the time. For more information, see chapter one.
} 
using the ghost of the Duke of Guise, the appearance and psychological influence of which shatters Clermont's Stoic exterior, and reveals the intense emotional and spiritual connection shared between the two men. The ghost underscores the spiritual-intellectual nature of male friendship which, as I will demonstrate, accords with early modern ideas touted by philosophers like Michel de Montaigne. However, the ghost further exaggerates that psychological connection by positioning the true realm of friendship as a Platonic ideal, beyond the capability of the living human to comprehend other than through inferior mental forms. This purely spiritual essence of friendship to which the Guise has access in death makes it so that Clermont can only maintain his connection with the Guise if he releases his rational soul from his mortal coil. The irony, however, is that Clermont's desire to achieve spiritual elevation - an ultimate aim of Stoicismis motivated by the overwhelming and personal attachment to others which Stoicism rigidly rejects.

Moreover, the spiritual-intellectual connection the two men share while the Guise is living becomes significantly emphasized by the duke's ghost. While Chapman depicts Clermont and the Guise as kindred souls in life, bonded by similar modes of thinking as well as a mutual affection for one another, the encounter with the ghost, a spiritual, otherworldly figure, prompts Clermont to view him as divine. But rather than the ghost being sent by God, as the author claims the spirit of Barwick's wife is, the ghost of the Guise comes to replace God for Clermont, to the extent that Clermont believes he must sacrifice his own life to return to the one who made him, his creator, his friend the Guise. The result is that Clermont perverts his prior Stoic belief, which is rooted in a belief that God is master of all, by using similar Stoic rhetoric to justify his fatal loyalty to the Guise. By luring Clermont towards his own death by emphasizing the spiritual chasm that exists between the two while they exist on different planes, the ghost of the Guise 
exploits the flaws in the idealistic morality of Stoicism and other philosophies like it. While they promote spiritual ascendance beyond the draw of materialistic desires, such rigid moral principles fail to account for the power of human connection, the spiritual nature of which is nonetheless rooted in emotional human frailties which a strictly Stoic outlook cannot sustain. If Hamlet and Antonio's Revenge question the validity of familial loyalty, and The Second Maiden's Tragedy complicates the criteria of gender identity, then The Revenge of Bussy D'Ambois shatters social expectations by demonstrating an internal bond between friends which supersedes the ideals of indoctrinated moral systems, and defies traditional expectations for masculine shows of strength and perseverance in the face of death.

\section{From Stoic to Suicidal}

In both the 1690 pamphlet and Chapman's play, it is the visual manifestation of the ghost which announces the deaths of Barwick's wife and the Guise, respectively. In the pamphlet, it is unlikely that Lofthouse or his wife would have been made aware of their sister's death had the ghost not appeared. Furthermore, it is evidently her appearance near the pond that leads Lofthouse's wife to conclude her sister was likely drowned. Similarly in Chapman's play, it is the appearance of the ghost of the Guise which first signals to Clermont that his friend is deada fact that he may not have otherwise believed had it only been reported to him. His initial impression is that, like the ghost of Barwick's wife, the visual manifestation of the spirit foretells a truth yet unconfirmed: "And th[is] true shadow of the Guise.../ Fore-running thus [his] bod[y], may approve / That all things to be done, as here we live, / Are done before all time in th'other life." (V.v.129-33) Here, Clermont implicitly admits the intellectual superiority of the world the ghost inhabits, as the ghost "fore-runs" the physical proof that the Guise has been murdered-i.e. the discovery of his corpse - and the occupants of the "other life", the spiritual after life, are 
privy to information about earthly matters before they occur on earth itself. In this way, the ghost's foreknowledge seems almost divine, and this contributes to Clermont's view of the ghost as god-like. His recognition of the intellectual elevation of the spiritual realm-which accords with Aquinas' theory on the potency of the soul outside of the body —is a significant realization because it is the philosophical basis of Clermont's justification for taking his own life. While some scholars have speculated that Clermont's suicide does, in fact, align with his Stoic beliefs, his final address to the spirit of the Guise, as we will see later, reveals that his motivation for the act is not the desire of a Stoic to leave the material world on his own terms. Rather, in his last breaths, Clermont confirms that his impulsive decision to take his own life is fueled by a need to reunite with his friend, who he willingly follows into death because of the divine status he accords the ghost — a status given to the spirit of the Guise, and not the Guise himself, because the ontology of the ghost presumes an intellectual and spiritual superiority which aligns him with the divine in a way that the flesh-bound Guise could never achieve. Even as the result allows him to fulfill the kind of spiritual elevation for which Stoics advocate, ultimately, Clermont's suicide is not driven by philosophical principles, but by an internal, psychological and emotional attachment to another person, and the desire to maintain a treasured earthly relationship into the realm of the spiritual.

Just as the pamphlet uses the language of reason to describe the psychological process by which Lofthouse and his wife come to determine their sister has been murdered-“laying Circumstance together", they "inferr'd", "concluding"-so Clermont attempts to use the Stoic reason he has hitherto lived by in order to deny the verity of the "true shadows". He does so, however, in order to quell the immediate fear the ghost produces - not fear of the ghost itself, but fear that it is an 'honest ghost' bearing the truth of the Guise's death. However, Clermont's 
grasping at reason to ease his anxieties proves insufficient, and his failure to persuade himself of the inexistence of ghosts using his own philosophical archetypes demonstrates a breakdown in his faithfulness to those ideals. Clermont's reactions suggests as much when he reiterates to himself what was thought about ghosts at the time:

That spirits should rise in these times yet are fables;

Though learned'st men hold that our sensitive spirits ${ }^{64}$

A little time abide about the graves

Of their deceased bodies, and can take

In cold condens'd air the same form they had

When they were shut up in body's shade (V.v.133-38).

First, Clermont recalls Protestant skepticism about the veracity of ghosts as the souls of the dead returned to earth - they must be "fables". However, he follows this recognition of the impossibility of ghosts with implicit references to contemporary scholarship which continued to investigate the complex ambiguity of the Ghost Question in early modern England. Both Richard Baxter and Cornelius Agrippa discuss the tendency of spirits to inhabit places close to where their bodies were buried, ${ }^{65}$ and Alfred Roffe writes on how the forms of early modern ghosts were thought to reflect their human forms (7). While Clermont begins by attempting to persuade himself of the inauthenticity of the ghost, as a way of denying the reality of his friend's death, the rest of the passage demonstrates the gradual unravelling of his rationalization, as he slowly slides towards common beliefs that the souls of the dead might return.

His fear that the image before him could in fact be the ghost proper of the Duke of Guise is realized in the next lines, when a messenger confirms that the Guise is dead, and Clermont

\footnotetext{
${ }^{64}$ Here referring to spirits which are able to be visually sensed, not the sensitive soul, which, as I have mentioned, was known to die with the physical body in death.

${ }^{65}$ Recall from chapter one that in his 1691 treatise A Certainty of the World of Spirits, Baxter treats "spirits" and "ghosts" as synonyms, while other scholars at the time make a more concrete distinction - he refers specifically to the spirits that haunt the grave as being "the souls of wicked men" (5). In The Invisible World, West also discusses how Agrippa believed that human souls could return to earth, and that the souls of wicked men tended to haunt the place of their burial while continuing to pursue their own earthly interests (52).
} 
responds “Avert it, heaven!” (V.v.139) Clermont's exclamatory language expresses his internal horror at the reality the ghost unveils. Just as Hamlet's mind becomes susceptible to the ghost's rhetoric because he "waxes desperate with imagination", so the psychological impact of seeing the ghost engenders an outpouring of emotion in Clermont, which overrides reason, and reveals the tragic feeling of true loss that cannot be rationalized. His shock at seeing the ghost is evident in his use of exclamations: "How strange is this! ... / . . yet living! / ... This our revenge!" (V.v.120-23) The significance of his exclamation is all the more evident when we consider that until this point, as many scholars have noted, ${ }^{66}$ Clermont has largely appeared even-tempered, especially in situations that might evoke passion in others. For example, at the start of the same scene where he encounters the ghost, Clermont confronts Montsurrey to avenge his brother's murder. However, his language is largely indifferent, formal, even methodical; he tells Montsurrey, "I confer no guards, / Nor imitate the murtherous course you took / ...not a minute more / My brother's blood shall stay for his revenge" (V.v.11-12, 14-15). By contrast, when Clermont hears confirmation of the Guise's death, anticipated by the appearance of his ghost, he begins to echo Antonio's boundless woe, calling the murder "the worst and most accursed of things creeping / On earth's sad bosom" (V.v.144-45). His use of superlatives- "the worst", "most accursed"-indicates that the Guise's death causes him far more grief than the death of his brother does.

The passionate response Clermont has to the ghost of the Guise elicits the kind of emotional attachment that one might expect from a husband seeing his wife — indeed, the kind of response we see from Govanius when he encounters the Lady's spirit. His shock shatters all bounds of reason, as even his final attempts to rationalize the ghost as a fable soon falter under

\footnotetext{
${ }^{66}$ See my previous discussion of Bergson, Kistler, Aggeler etc. who discuss Clermont as a largely Stoic character.
} 
the overwhelming effect of the ghost in confirming in Clermont's very core that his friend is dead. Like Hamlet's “prophetic soul”, here, Clermont's horrified reaction signals his belief both in what he has been told, and, consequently, in the ghost's authenticity. In the span of the twenty lines following the appearance of the ghost of the Guise, Clermont moves from his initial fearful reaction, to an attempt to deny the cause of his terror, to finally accepting the truth he so feared. The power of the ghost to cause Clermont to abandon his Stoic persuasions suggests that the strength of his philosophical belief cannot match the strength of his feelings for the Guise; furthermore, it causes one to question the degree of his devotion to those ideals in the first place. $^{67}$

Kin, less than Kind

As briefly indicated above, Clermont's extreme reaction to the Guise's death presents an intriguing opposition to his more indifferent response to the death of his brother, Bussy. This is evident in the way Clermont treats both his brother's ghost and the revenge it calls him to undertake. Kistler aptly observes that Clermont is never so distraught by his brother's death as to consider any sort of action, much less revenge, until the ghost appears to demand it (131). When he does agree to avenge his brother's murder, Clermont does so, quite clearly, out of duty only (131), a duty which proves to be heavily burdensome. He explicitly expresses his reluctance to take on the role of revenger: "I repent that ever / ...I yielded to revenge his murther. / ...never private cause / Should take on it the part of public laws" (III.ii.109, 111, 115-16). The fact that Clermont claims to have "yielded" to revenge connotes a kind of coerced surrender, as though

\footnotetext{
${ }^{67}$ Clermont notes how he tends to actively bury his passions in order to assume a Stoic guise, the decrees which, he admits, "I wonder much / At my inconstancy in these decrees / I every day set down to guide my life" (III.iv.11-13). The fact that the decrees must be "set down", "every day" indicates that they are neither necessarily as natural as his passions, nor are they secure enough to stand against that passionate nature without constant reiteration.

Furthermore, the fact that Clermont admits his own "inconstancy" in practicing those decrees provides reason why he feels he must "set" them down often, to keep himself in line, as though he knows his own propensity to give into his passions.
} 
the ghost somehow forces his decision. However, Clermont's underwhelming reaction to the call of his brother's ghost, and to his brother's death in general, indicates that even the murder of his brother, the closest of kin, cannot emotionally affect Clermont. His indifference is all the more evident when compared to the reaction of Thomas Lofthouse at seeing the ghost of his sister-inlaw. While, like Clermont, Lofthouse seems largely unaffected by the ghost, it is only mere hours later that the apparition returns to his thoughts "and discompos'd his Devotion." The author of the pamphlet implies that Lofthouse's motivation to pursue an investigation into the veracity of the ghost was a matter of conscience, as he begins to think about the apparition again while at prayer with his family. The pamphlet suggests that Lofthouse is not moved by social duty - that is, by the awareness that society expects him to act in a certain way to fulfill a required familial obligation to his dead relative — but by the internal realization that he needs to do right by his kin. Clermont, by contrast, does not express a similar sense of personal conscience when his brother's ghost tasks him with vengeance.

Here, Chapman veers from the traditional path of the passionate revenger (Bergson 44). When the Ghost of Hamlet calls his son to revenge, Hamlet is so overcome with feeling and determination, that the constant anticipation of the act completely consumes him. When the Ghost of Andrugio calls on Antonio for vengeance, Antonio entertains the task with excessive passion and violence. Clermont, however, is methodical, even honourable, in his approach to revenge. He becomes concerned with conducting himself in proper fashion, allowing Montsurry the chance to defend himself (V.v.21), even complimenting him on dying in a manner that was "noble and Christian" (V.v.112). Not once does he consider stabbing Montsurry in the back, as Hamlet does when Claudius is turned away from him at prayer, or engaging in the ruthless murder of Montsurry's loved ones, as Antonio does. Rather, Clermont will not even allow 
Montsurry to fetch a different sword for fear "'tis a trick / for you to show your back" (V.v.3637), as though Montsurry's intentional self-neglect would encourage Clermont to kill him ignobly.

Friendship's Fire

Clermont's double approaches to death suggest a contradiction much like what Govanius experiences. Where Govanius first laments the suicide of his brother as irrational and hasty, he later appears willing to undertake the same act to rejoin his Lady in death. Clermont's attitude to the duel with Montsurrey is calculated, strategic, and formal. However, any concern with dying in a way that is "noble and Christian" altogether disappears at the end of the play after he encounters the ghost of the Guise. While nearly two acts pass between Clermont's first mention of the ghost of his brother tasking him with vengeance and the death of Montsurrey, ${ }^{68}$ within the span of forty lines Clermont weighs the possibility of living in the world without the Guise, and decides he would rather die than be without his friend (V.v.149-193). While his response to the ghost of his brother is gradual, as Clermont attempts to abide by the rules of proper conduct set down by seventeenth-century society, his response to the ghost of the Guise is erratic and impulsive, and prompts him to die in a way that was considered neither noble nor Christian. Clermont explains his desire for death in terms of friendship: "But friendship is the cement of two minds, / As of one man the soul and body is, / Of which one cannot sever, but the other / Suffers a needful separation" (V.v.157-60).

The power of male friendship to elicit such feelings of unbreakable kinship were not unusual in early modern England. Michel de Montaigne's “De L'Amitié”, from his 1580 Essais, is perhaps one of the most well-known examples from the period of an author praising the value

\footnotetext{
${ }^{68}$ The audience first learns of the ghost's appearance at III.ii.109-112, and Clermont duels Montsurrey at V.v.
} 
of male friendship, above even marriage. Montaigne defines friendship, between men specifically, as "une chaleur générale et universelle, tempérée au demeurant et égale, une chaleur constant et rassise, toute douceur et polissure, qui n'a rien d'âpre et de poignant...s'étant parfaitement commis l'un a l'autre...et faites guider cet harnois par la vertu et la conduite de la raison" $(111,116) .{ }^{69}$ Like Clermont's, the language Montaigne uses to describe friendship seems surprisingly romantic —one might associate the image of the fire especially with the burning passion between lovers. However, Montaigne's "chaleur" is a spiritual flame, meant to entwine the minds and souls of two friends together along the lines of reason and shared intellectual interest. He even explicitly condemns that lover's flame as "tous les insolents et passionnés efforts que peu[vent] produire une ardeur immodérée" $(112) \cdot{ }^{70}$ For Montaigne, the key to perfect friendship between men is moderation and temperance, as such qualities demonstrated a soundness of mind and reason which was thought to elevate men above women. Clermont's impulsive response to seeing the ghost of the Guise supersedes any sense of moderate temperance. Even as his reference to the unbreakable kinship between friends echoes Montaigne's own philosophy—wherein he quotes Horace, "illam meae si partem animae tulit / Maturior vis, quid moror altera / Nec carus aeque, nec superstes / Integer?" (121-22) $)^{71}$ Montaigne does not advocate that one should in fact follow their friend to the grave. Rather, he acknowledges "il n'est action ou imagination où je ne le trouve à dire comme si eût-il bien fait à moi" (122). ${ }^{72}$ Montaigne recognizes that the death of such a friend, who constitutes the other half

\footnotetext{
69 "A general and universal fire, but temperate and equal, a constant established heat, all gentle and smooth, without poignancy or roughness...they [friends] absolutely give themselves up to one another...all this guided by virtue and with the conduct of reason." (Project Gutenberg translated by Charles Cotton)

70 "All the insolent and passionate efforts that immoderate ardour can produce." (Project Gutenberg)

${ }^{71}$ Montaigne translates this in French as, "Si l'effort anticipe des Parques, a ravi cette douce moitié de mon âme, pourquoi tarde en moi l'autre moitié, n'étant plus ni cher à moi-même, ni plus que demi survivant?" (122) In English, "if that half of my soul [my friend] were snatched away from me by an untimely stroke, why should the other stay?" (Project Gutenberg)

72 "There is no action or imagination of mine wherein I do not miss him.” (Project Gutenberg)
} 
of a person's very soul, will bring a grief that one will carry with him until the end of his days. Clermont, however, refuses to live that long without his friend, and instead acts against reason and judgment by committing suicide. In fact, the actions of Thomas Lofthouse, described in the 1690 pamphlet, more closely align with Montaigne's friendship standards than Clermont's own response. For, Montaigne also denotes that true friends “plus que toute autre chose, de s'entrebien-faire, celui qui en prête la matière et l'occasion est celui-là qui fait le libéral, donnant ce contentement a son ami d'effectuer en son endroit ce qu'il désire le plus" (117). ${ }^{73}$ In the cases of the ghosts of Old Hamlet, Andrugio, and the Lady, "de s'entre-bien-faire” required Hamlet, Antonio and Govanius, respectively, to undertake some sort of revenge so that the wandering souls of the ghosts might be put to rest. Indeed, Lofthouse continues this pattern of being useful to the ghost of his sister-in-law by discovering the truth of her death and apprehending her murderer. However, Clermont refuses to do right by the Guise in a similar way; he quickly dismisses the idea of vengeance ${ }^{74}$ and focuses instead on his own internal turmoil at the prospect of living without his friend. In so doing, Clermont rejects Montaigne's friendship standard, which advises that friends act in the best interest of one another, in order to avoid spending more time than necessary apart from the Guise.

Evidently, Clermont's response to the death of his friend exceeds early modern expectations of common male friendship, resembling more the desperate action of lovers like Romeo and Juliet. ${ }^{75}$ For François de Belleforest, such a heightened emotional response between

\footnotetext{
73 "Above all things studying how to be useful to the other, he that administers the occasion is the liberal man, in giving his friend the satisfaction of doing that towards him which above all things he most desires" (Project Gutenberg).

${ }^{74}$ Having discovered that the Guise's murder was commissioned by the king, Clermont says "there's no disputing with the acts of kings, / Revenge is impious on their sacred persons." (V.v.151-52).

${ }^{75}$ Arguably, Shakespeare does include a similar homosocial connection in Romeo and Juliet between Romeo and Mercutio, particularly during the passionate tragedy of Mercutio's death scene. However, I would argue that Romeo acts in accordance with Montaigne's friendship standards - he does not kill himself because his friend is dead, but vows to avenge him, to be useful to him: "fire-eyed fury be my conduct now! / Now Tybalt, take the villain back
} 
friends could be a result of a supernatural presence. Belleforest dedicated the last chapter of his 1575 Histoires prodigieuses to ghosts which "se rapportent à l'amitié d'entre les hommes" (qtd. in Chesters 130). ${ }^{76}$ In his chapter, Belleforest cites a story from Alessandro Alessandrini, wherein a man is confronted by the ghost of his recently deceased friend, which then strips himself and gets into bed with his friend. The friend, being terrified and appalled, struggles to get away from the ghost, which angers the apparition and causes him to vanish (Chesters 131). While Timothy Chesters acknowledges the blatant Freudian reading about male homosexual desire one might be tempted to make here, Belleforest himself performs no such interpretation. Instead, for Belleforest, the encounter is about homosocial male intimacy reminiscent of the shared bond between friends when both were living - for Belleforest, it is "the occult force of friendship" which prompts the ghost's appearance in the first place (131). Belleforest's version of the male friendship present, even beyond death, in Alessandrini's story is very much in line with Chapman's depiction of the friendship between Clermont and the Guise. Like Montaigne's initial description of the "chaleur", and the friend's ghost exhibiting intimate notions towards his former companion, Clermont and the Guise often use language that borders on amorous when speaking of one another; the Guise refers to his friend as "my love" (II.i.80), and takes possession of him in declaring him "my Clermont" (129, emphasis mine). But, even as Montsurrey observes how the Duke of Guise and Clermont are often caught "whisper[ing] together" (I.i.147) as young paramours might do, I would argue that there is nonetheless no pervasive sexual undertones in their relationship. Rather, as aforementioned scholars have

again, / That late thou gavest me; for Mercutio's soul / is... / Staying for thine to keep him company" (III.i.119-23). Furthermore, the focus of the play is the relationship between the young lovers, whereas in Chapman's play I argue that the primary focus, and the relationship with the most consequence, is the one between Clermont and the Guise. 76 "Have to do with friendship between men". 
highlighted, Clermont's largely Stoic personality throughout the play pervades his attention towards earthly material things, from fortune to the flesh. ${ }^{77}$

In accordance with his overarching spiritual outlook, his close relationship with the Guise throughout the play is perhaps most aptly described as a meeting of kindred souls. Such is evident not only in their mutual praise of one another ${ }^{78}$ but in the very principles inherent in their opinions of one another's actions. When Baligny challenges Clermont on the Guise's infamous slaughter of the Huguenots, Clermont defends his friend: "had faith and true religion been preferr'd / Religious Guise had never massacred" (II.i.233-34).${ }^{79}$ Clermont asserts that, counter to popular opinion, the Guise's massacre of the Huguenots was the result of a lack of true faith on the parts of the persecuted; the persecutors were, therefore, acting with the best interests of the state in mind by punishing those who would seek to divert them from true religion. One hundred lines prior, the Guise praises Clermont for acting similarly, as he states "Brutus is reviv'd in him / Whom he of industry doth imitate" (II.i.103-04). And even while the Guise momentarily laments that Brutus should have been a "conspirator" (107), Baligny quickly reminds him of the reason the man should be praised, in line with why the Guise lauds Clermont: "Caesar began to tyrannize; and when virtue / Nor the religion of the gods could serve / To curb the insolence of his proud laws / Brutus would be the gods' just instrument" (II.i.109-112). Like Clermont claims of the Guise with the Huguenots, so the Guise's reference to Brutus highlights Clermont's willingness to do what is necessary in order to uphold the laws of the state and of

\footnotetext{
${ }^{77}$ Clermont mocks men's material ambitions, and extols the inevitable triumph of God's plan in his speech at III.ii.49-60.

${ }^{78}$ For example, the Guise lauds Clermont "for his natural zeal to right / he will be fiery... / yet when he lists / he can contain that fire" (II.i.91-94), and when Baligny attempts to undermine the Guise's worth, Clermont responds, "What one act can you name / Suppos'd his stain, that I'll not prove his lustre?" (II.i.202-203)

${ }^{79}$ Clermont refers here to the Duke of Guise's military role in slaughtering French Protestants in the $1560 \mathrm{~s}$ at the order of Catherine de Medici, Queen Mother of France (Brittanica.com). Christopher Marlowe dramatizes the event in his 1593 work, "The Massacre at Paris", in which the Duke of Guise is also a prominent character.
} 
God. Both men recognize and admire this steadfast righteousness in the other, even against those who might view such actions as violent or extreme. Such like-mindedness contributes to the intimate connection the two men share throughout the play.

\section{Death of a Stoic}

The significance of their intellectual connection comes to the forefront when the ghost of the Guise appears. Until that point in the play, despite the difference in their stations, Clermont and the Guise treat one another as equals - if anything, the Guise tends to elevate Clermont above himself in praise.$^{80}$ However, the mutual affection and intellectual connection the two men share is altered by the ghost's arrival. As a rational soul free from its body, the spiritual intellect of the Guise has entered a higher plane of existence, which Clermont himself admits when he recognizes that "things to be done, as here we live, are done before all times in th'other life" (V.v.131-32). As I discussed previously, the foreknowledge the ghost exudes, by precedingtherefore almost foretelling — physical evidence of death, proves to Clermont that their former like-mindedness has been complicated by his friend's passing. In order to reobtain the mutual intellectual connection they shared in life, Clermont must ascend to the same spiritual plane as the Guise. While Clermont momentarily concedes that he could "play the worldling (no man loving / Longer than gain is reap'd" (V.v.153-54), his use of the world "play" indicates that forgetting the Guise after death, as though their friendship was only earthly, temporary, would be to play a part that was not true to Clermont's internal feeling. Furthermore, Clermont would indeed need to pretend to be a worlding - that is, someone who exists in the world, body and soul, and feels a sense of belonging there - because his heart, his soul, and his thoughts would always be elsewhere, vying to reobtain his connection with the spirit of the Guise in the afterlife.

\footnotetext{
${ }^{80}$ See the Guise's speech at IV.iv.14-46 where the praises Clermont's virtues.
} 
The freed rational soul of the Guise, which manifests visually as his ghost, highlights the spiritual and intellectual gap between the friends that cannot be rectified while Clermont lives.

Clermont emphasizes his willingness to expose himself to the truth of his mortality if it means he can be with the Guise again:

Guise, O my lord, how shall I cast from me

The bands and coverts hind'ring me from thee?

The garment or the cover of the mind, The human soul is: of the soul, the spirit

The proper robe is: of the spirit, the blood;

And of the blood, the body is the shroud.

With that must I begin then to unclothe (V.v.168-74).

Just as Clermont calls the soul the "cover of the mind", it is telling that when the soul of the

Guise is exposed to him, Clermont uncovers the truth of his deep feeling for his friend and

patron, forsaking all previous Stoic rationale in favour of disclosing his desire to be reunited with the Guise, even if that means giving up his own life. For Clermont, moving from life to death is as simple as removing his clothes - a shedding of the constraints of the body which prevents his soul from joining with the Guise's. He will let his blood flow, in order to free the spirit, and subsequently, the soul, which is housed within. In so doing, Clermont literalizes the root of his relationship with the Guise as a meeting of like souls, which have thereunto been forced apart by both the bodily cage and social bounds that dictate acceptable terms of relationships between men.

Like in Belleforest's retelling, it is the presence of the ghost which catapults the relationship between Clermont and the Guise beyond the realm of idealized male friendship into something less conventional, something super-natural. Clermont's final debate with himself embodies this shift; though he uses the rhetoric of Stoicism, his speech gradually devolves to reveal that his reasoning is a façade, and that his true motivation is not Stoic, as scholars like 
Michael Higgins suggest, but personal. He begins by justifying that even though he "should survive [to] be wonder'd at" by others (V.v.155),

Since I could skill of man, I never liv'd

To please men worldly, and shall I in death,

Respect their pleasures, making such a jar

Betwixt my death and life, when death should make

The consort sweetest, th'end being proof and crown

To all the skill and worth we truly own? (V.v.162-67) Clermont's language here seeks to refute the idea that he should stay living merely so others might think well of him. Doing so, he suggests, would only betray the Stoic philosophy by which he has so long lived, as it would mean "pleas[ing] men worldly" and "respect[ing] their pleasures" in ways he never cared to do previously. Not only would living until the point of natural death, or death at the hand of another, mean Clermont abandoning his life-long philosophy, it would mean betraying his own self, as it would create "such a jar / betwixt my death and life" where the manner of his death would not at all resemble, reflect or honour his mode of living. However, Clermont states that he never lived to please men of the world. But the Guise is no longer of the world. The Duke of Guise in the flesh complicates Clermont's philosophical aims, being both a person on whom Clermont depends for financial and sociopolitical support, ${ }^{81}$ as well as the emotional trigger which threatens the rational exterior of the aspiring Stoic. But because the ghost is not a worldly figure, Clermont's desire to join his spirit with the Guise's does not explicitly defy his own moral standards.

But the philosophical ruse with which Clermont attempts to justify his thoughts of suicide in Stoic terms soon falters. Even as he speaks of dying as a Stoic might do, citing death as proof and crown / To all the skill and worth we truly own", a true Stoic would equate that skill and

\footnotetext{
${ }^{81}$ Baligny refers to Clermont as the Guise's "dear minion" and Monsieur accuses Clermont of being a beggar, that the question for him is not "what meat to dine with... /... / But where to beg it: whether at my house / Or the Guise's" (I.i.146, 244-247).
} 
worth to God, and so leave the earth comforted, knowing he is bound for the ultimate goal:

everlasting life. Clermont himself touts similar principles just the act before the ghost appears:

A man to join himself with the Universe

In his main sway, and make (in all things fit)

One with that All, and go on round as it:

But to consider great Necessity

All things as well refract as voluntary

Reduceth to the prime celestial cause:

Which he that yields to with a man's applause,

And cheek by cheek goes, crossing it no breath,

But, like God's image, follows to the death,

That man is truly wise" (IV.i.139-152).

Here, Clermont dismisses any attachments other men might claim to earthly things, as the ultimate goal for a Stoic is to "join himself with the Universe"-life is only a means for eventual spiritual release, in which form one can become absorbed into "the All". And as it is the "One" and "All" (God) by and for whom people are created, so it is their responsibility, the "great Necessity", to always be faithful to the "prime celestial cause", and to follow the will of the Almighty unto death. This signifies the Stoic belief to which Clermont has tried to dedicate himself, and it is the same basis of belief that leads him to take his own life. The difference by the end of the play, is that the appearance of the ghost has caused him to reconfigure his thoughts on what, or who, constitutes his "prime celestial cause". Indeed until he finally dies, he spends his breath praising the Guise as his master (V.v.179), the one who calls him home. Clermont reveals that his dream of eternal life is not with God, but with the Guise, who has come to signify the divine for him. It should be noted that Clermont makes divine allusions when speaking of the Guise twice prior to the final act. At the end of Act Two, he foreshadows his own death when he claims the Guise "deserves / My love and life, which through all deaths I vow" (II.1.173-74); again, at the beginning of Act Four, he tells the Guise, "your will is infinite" (IV.i.73). However, 
these references are sparse and subtle in comparison to Clermont's final speech, which is structured around the divine praise of his dead friend.

Here, the psychological impact the ghost of the Guise has on Clermont's Stoic sensibilities causes Clermont to exceed the bounds of Stoic belief altogether. While nonetheless motivated by the same basic principles as at the start of the fourth act, Clermont shatters the very foundation of Stoic belief when he elevates the Guise to the status of God Himself, referring to his friend as the one who "alone gave life to me" (V.v.150). Clermont also calls himself "thy [the Guise's] creature" (V.v.193), as though the Guise crafted the very body Clermont now sacrifices in his honour. His final words "I come, my lord" (193) is further reminiscent of Jesus' "Father, into your hands I commend my spirit" (Luke 23:46); the ghost of the Guise becomes the master calling (V.v.183) his servant home, and Clermont is eager to obey. The ghost reveals that, despite his Stoic musings, the Guise is, and has been, at the root of Clermont's "All"; he is the centre of the Universe to which Clermont desires return, and eternal bond. Furthermore, his segue between thinking of dying on his own terms to show the "skill and worth" of his life, as a Stoic might do, and calling to the Guise for guidance in death, reveals that the only way for Clermont to die in the same vein as he lived, and to dedicate his death to the worth he found in life, is to die for the Guise, who alone gave him life, and his very reason for living. Unlike Clermont, Lofthouse uses the language and methods of reason to investigate the death which the ghost reveals in order to uphold the moral standards of the community and to do right by his family. Clermont, however, begins by using the rationale of Stoic philosophy to justify pursuing his deepest passion until the truth of that passion perverts the philosophical root of Stoicism, and overshadows any attempt at reasoning or moral judgement. 
Clermont's encounter with the ghost of the Guise is thus so significant because it is the moment when Chapman takes male friendship beyond the bounds of sixteenth-century tradition, when the chaleur between the living becomes an intimate spiritual longing that is not quite amorous, but more than homosocial. The effect of the ghost is religious (though it perverts traditional religious hierarchy), even ecstatic. The immediate and immense impact that the ghost has on Clermont reveals the depth of the love the two men share, a love that exceeds the bounds of conventional understanding or expectation, a love which unveils the more vulnerable, emotional interior of an otherwise hardy, reasonable masculine exterior. His willingness to die for his friend, without ever considering revenge stands in direct contrast to his reaction to the ghost of his brother, whose request for vengeance Clermont takes on reluctantly, almost robotically_unlike Thomas Lofthouse who, from a point of conscience and kinship, put the ghost of his sister-in-law to rest by finding her murderer. While the ghost of Barwick's wife directs her brother-in-law towards a path of familial honour and moral justice, the ghost of the Guise, however brief his appearance is, subverts fraternal, religious, even marital loyalty and love beneath a bond between men that blurs the lines between all three relationships.

\subsection{Coda}

While Hamlet and Antonio's Revenge use their paternal ghosts to create a psychological space for resisting the conventional expectations for men, sons in particular, under patriarchal rule, The Second Maiden's Tragedy and The Revenge of Bussy D'Ambois explore the affective potential of ghosts of loved ones to unveil complex gendered psychologies which subvert traditional social relationships. In Middleton's play, Govanius' redemption is only made possible by the return of the Lady's spirit — at the same time that she must go to him for help, he finds the strength and courage to take on the Tyrant only because her spirit wills it. Thus, even his final 
achievement of the criteria expected of seventeenth-century Englishmen hinges on his dependence on the Lady, who first exhibits the firmness of conviction and reason that Govanius lacks throughout the play. And once Govanius had redeemed himself in the Lady's eyes by reobtaining her stolen corpse and killing the Tyrant, whose relentless pursuit resulted in her death, Govanius refuses to be completely reabsorbed into his duties as a son of the patriarchy. While he reluctantly takes up the political position which the Tyrant had usurped from him, his vow to remain unwed prevents the preservation of his dynastic line upon which the very idea of patrilinearity depends.

While Govanius' desire to reunite with the Lady is conventionally romantic, the relationship between the Guise and Clermont is more complex, especially as Clermont's reaction to the Guise's ghost is so similar to that of Govanius' romantic longing. It is important to note that despite what might be read by Freudian disciples as homosexual undertones, modern critics of the play tend to treat Clermont's relationship with the Guise as a mere extension of his Stoic persona - suicide being typical of those who reject the control of the material world (Higgins 191). Others view Clermont's bouts of passion to be a result of his close friendship with the Guise; just as Clermont adopts some of the Guise's feeling, so the Guise shows his stoic side as he approaches death (Aggeler 12) - a mutual influential exchange of personality traits that is to be expected between friends. Even sixteenth-century writers like Montaigne and Belleforest deny such intimacy between friends as being irregular or unnatural. However, the ghost propels the relationship between the two men beyond the bounds of earthly friendship and into a realm of spiritual attachment that cannot quite fit into any seventeenth-century category or tradition. The otherwise calculated, level-headed warrior of the French court succumbs to the same typically effeminate passions and impulses as Govanius, in his unwillingness to save his Lady's virtue and 
so risk living without her. In both plays, the male protagonists' encounters with ghosts of deceased loved ones reveal the complicated truth of their interiority: that it does not, cannot ascribe strictly to male or female, as unmitigated feeling precludes such stark distinctions - such is the reality of being human. 


\section{Chapter Three Devils and the Dissolution of Identity}

Unlike issues of ambiguity and division surrounding the Ghost Question, the existence devils — the Devil in particular — was rarely, if ever, up for debate in early modern England. One of the few people to second guess the reality of devils was Reginald Scot in the Discoverie of Witchcraft, but, as Kristen Poole notes, that postulation was far from normal; rather, Scot's claim would have been "more radical and less rational" in his own day ("Ovidian" 195), where belief in hell and the devil was so prominent. In fact, the existence of the devil was not thought to lose credibility until at least the middle of the eighteenth-century, and Kilian Schindler observes that the "obsession with the devil reached a high water-mark with the witchcraft persecutions of the sixteenth and seventeenth centuries" (117-118).

The devil was, therefore, a persistent influential presence in both theological discourse and cultural symbolism, becoming a frequent feature of popular drama, circulated treatises and everyday moral rhetoric. Such is evident from the numerous published records of people encountering the devil in his many forms. An anonymous author in 1647 relayed one such account, wherein a mysterious figure appeared in the yard of a M. Yonge, announced by "a great clattering of Iron chaines and bolts... a great screeking and yelling and howling like a dogge." 82 The noises were followed by "a great tall blacke man (or rather Devill) at least six yards in height, with long black shaged haire, his eyes as bigge as two ordinary pewter dishes, flaming like fire, and out of his mouth there seemeth to fly fire which flashes into the windows of the

\footnotetext{
82 The pamphlet cited here is entitled Fearefull apparitions or The strangest visions that ever hath been heard of. It is a spirit that constantly every night haunts one Mr. Youngs yard in Lumbard-street, neere to the Golden Crosse, which hath played such prancks, and appeared in such severall and horrid shapes, that many divines and other learned men, who have come armed with a full resolution and with an intent to have spoken unto it or (at least) to have look't upon it, in the very attempt thereof have fallen into a kind of a distracted extasie, and were neither able to speak or stand, to the great wonder and terrour of all that were eye witnesses thereof, 1647, printed for John Hammond, Wing (2nd ed.) / F576, Early English Books Online. 10 Nov 2018.
} 
house like lightening". While the pamphlet itself explicitly states the figure in question was a manifestation of the Devil, even those skeptical of such a claim could not ignore the signs in the description which support this deduction. The devil was often said to appear dressed in black (Nashe 5), and the fire in the man's eyes and mouth further suggest a visitor from hell. Moreover, the preceding howling and the shaggy hair indicate a canine association, and the devil was also known to appear in the form of a big black dog (Perkins 106). ${ }^{83}$ The author is precise in his relation of the strange and fearful figure, citing also his "horrid and dismal" voice-yet another sign of a demonic presence (Taillepied 30) — and the powerful fright he cast upon bystanders, who found themselves awe-struck, unable to move, their hair standing on the back of their necks. While the author is not explicit in stating the reason for relaying the account, the terrifying experience described is implicitly imbued with a warning to every reader to avoid the devil at all costs.

However, many authors of similar pamphlets are not as ambiguous in their accounts; some, as I discussed in terms of ghosts in the previous chapters, used encounters with devils, too, to promote a specific moral. One pamphlet, published anonymously in 1641, tells of a group of Jesuits, along with fellow "papists", who conjured the devil in an alehouse one night using their rosary beads.$^{84}$ The author relays that after "their loud exclamations and popish exercise, there appeared among them a strange monster: or if you will, the Devill in the shape of a monster, all as black as pitch, as bigge as a great dog". The pamphlet refers constantly to those present as

\footnotetext{
${ }^{83}$ As he does in Thomas Dekker and William Rowley's play The Witch of Edmonton.

${ }^{84}$ Anonymous, A Relation of a strange apparition in an ale-house next doore to the White Horse, against Sommerset-House in the strand where a company of papists were at their exercises: as is conceived the devill in an ugly black shape disturbing them, and tea-ring the rugge and scattering it in pieces up and down the roome: with a relation of a iudgement that strangely fell umpon one at Mr. Mundayeshouse in Little Brittaine : who whilst he was cursing of Mr. Burton, Mr. Prinne and doctor Bastwicke his eares fell a bleeding to the amazement of the beholders, 1641, printed for Richard Smethrust,, Wing / R795, EEBO. 10 Nov 2018.
} 
"papists", thus making a clear association between Catholics and the devil. Using the devil for their own means, Protestants could steer people away from the old religion and towards a reformed moral righteousness.

These pamphleteers were not the only ones who sought to manipulate popular belief in the devil for a specific purpose. Many early modern playwrights, too, included devils, demons and other nefarious hell beasts in their works. These personages fulfilled various functions, from typical immoral monstrosities in service of a larger didacticism, to representations of the very worst aspects of human nature. However, because of the devil's negative theological associations, many tracts, pamphlets, and plays too, construe and consider him strictly in the realms of theology and morality. But I argue that in so doing, these records can undercut the vast psychological potential of the devil, not only as a manifestation of characters' immoral thoughts or desires, but as a stimulus for their critical re-evaluation of the very systems and doctrines in which the devil is imbued. Lucifer is, after all, perhaps the most iconic representative of larger scale resistance to externally imposed norms, but the nature of religious rhetoric has inscribed him and connected ideas of hell within a specific—arguably limited—narrative. Early modern playwrights like Christopher Marlowe and Thomas Middleton recontextualize the devil as a promulgator of resistance by demonstrating how his interactions with human characters can create internal reconsiderations of prominent sixteenth and seventeenth-century socio-cultural and religious beliefs.

In this chapter, I analyze Marlowe's Doctor Faustus and Middleton's A Mad World, My Masters to demonstrate how Faustus' and Penitent Brothel's interactions with Mephistopheles and the succubus, respectively, uproot key aspects of early modern psychological identity—that is, how the characters thinks about themselves and why. In so doing, the encounters cause these 
characters to experience the potential problems inherent in mindlessly adopting certain sociocultural beliefs without psychological critique. In the case of Faustus, his engagement with Mephistopheles unveils a troubling internal struggle with thoughts surrounding the fate of his soul - an uncertainty that does not hamper him at the beginning, when his focus rests on his intellectual exploration of the empirical world. As Faustus becomes more involved with the devils and more deeply entangled in his contract, his confidence in his own abilities to procure knowledge increasingly fades into the instability of larger, incomprehensible spiritual questions, and so he yields much of his will to the devils as his own psychological coherency disintegrates. I argue that at the end, Marlowe's play reveals the harrowing difficulty of reconciling the Protestant uncertainty of the afterlife with the increasing desire to know, learn, and discover which marked the early modern period. Faustus demonstrates how this contrast between a belief in people's ability to extend beyond the realms of prior knowledge and the reiteration of their ultimate unknowing in spiritual matters can result in a fractured and unstable perception of themselves and the world they inhabit. In A Mad World, the succubus forces Penitent to confront his role and responsibility in his affair with Mistress Harebrain. The she-devil disorients the righteous preaching that Penitent undertakes to minimize the focus on his own accountability, and presents him with the uncomfortable reality that the demonization of women, which Penitent himself propagates, is caused not by women themselves, but by the men who fabricate a specific sexual role for them. The brief conversion scene in Middleton's play has a large impact in destabilizing the foundations of the early modern gender hierarchy, calling into question the dynamics of power and sex which men can manipulate in their own favour. Both plays use the figure of the devil in ways that extend beyond the typical morality structure. Instead, Marlowe and Middleton demonstrate that devils are characters that can produce significant psychological 
effects in the characters they encounter, particularly when it comes to reassessing the nature of the beliefs that define who they are and how they perceive themselves.

\subsection{The Devil in Early Modern England}

While the Protestant Reformation had a vast impact on people's conception of the ghost, scholars agree that the religious shift in England had no real effect on beliefs about the devil and the demonic (Clark, Demons 127). P.G. Maxwell-Stuart, for example, argues that demonologies in the sixteenth century, whether Catholic or Protestant, "tended to make similar points" (178). The only arena in which Protestants differed significantly from Catholics on matters concerning the devil was in regards to possession—which Protestants treated as a mental illusion that, as such, did not require the aid of a priest or minister (172). But people generally believed that Satan's aim was to lead humanity away from God; the overall consensus was that he was "wicked", "delight[s] do to Mischiefe", "ambitious to be worshipped and to deceive men" (Baxter 5), "a lyer and a murtherer" (Anderson SIV) of "damnable evil" (Sinclair A2). As such, scholars from various disciplines sought to warn their communities against the malice and deception of the devil by circulating morally instructive treatises. In his Daemonologie, James I counselled his constituents to be wary of the numerous ways in which the devil might appear and seek to deceive them, writing that "he may make himself palpable, either by assuming any dead bodie... or else by deluding as well their sense of feeling and seeing, which is not impossible to him to do since all our senses, as we are so weake, will often times be deluded" (52). Here, the king alludes both to the Protestant belief that any manifestation of the dead is the devil in disguise, as I discussed in the previous chapters, and to the ability of the devil to afflict a person not only spiritually, but physically and psychologically as well —he was thought to be capable of penetrating, and thereby manipulating, the internal and external senses. As we will see in my 
reading of the play, Marlowe exploits this characteristic in his depiction of Mephistopheles' influence over Doctor Faustus. James' claims about the devil seem to echo the views of Calvinists as well, as James Ross MacDonald observes that John Calvin himself believed devils “exercise power over [people's] minds and bodies, and misuse them as if they were slaves for every shameful act" (827). It is because of the devil's cruel and powerful nature that Calvin also vehemently encouraged people to believe that he was real, so they would be better equipped to guard against his temptations (823).

While James I was writing at the end of the sixteenth century (Daemonologie was published in 1597), nearly one hundred years afterwards, Richard Baxter published A Certainty of the World of Spirits (1691), followed a decade later by John Beamount's An Historical, Physiological and Theological Treatise on Spirits, Apparitions and Witchcraft (1705). Baxter reemphasizes the devil's quest to taint good Christians, particularly "by his Temptations...in all our Duties molesting or hindering us" (234). Furthermore, he issues a strong and explicit warning against allowing Satan to "winn", which occurs "if he can get [people] to prefer Earth before Heaven, and Wealth and Honour before Holiness, and to be lovers of fleshly Pleasures more than of God and keep them from Serious Consideration, and from thinking whither they are going and how all their Carelessness, Ease and Sin will end" (15). Baxter draws attention to the consequences of allowing the senses to be manipulated and deluded by the devil—namely that the devil will use his influence to divert people's attention towards pleasures of the flesh, and so distract them from contemplating the eternal fate of the soul. The inevitable result of such sensuous diversion is that people forget to care for their own spiritual well-being, and so temporary temptations give way to infinite damnation. 
While people agreed on the general nature of the devil and the need to always guard their souls against his temptations, views on who the devil primarily targeted were more varied. James I wrote that the devil preys on those already in despair, and then provides "a suddaine and certaine waie of remedie, upon condition that they follow his advise and do such thinges as he will require of them" (32-33). James echoes popular opinion that those who are spiritually vulnerable - i.e. uncertain or unstable in their faith in God - are most susceptible to the lures of the devil (Johnstone 61). Baxter agrees, stating that those who are called upon to do the devil's work are the people "that madly contradict God's Word... and Argue against Faith and Holiness: They that deride and mock at the obedience of God's commands... that silence necessary Faithful Preachers" (11). For Baxter, it is not just those in despair, but those who have given up on faith altogether who are most likely to find themselves in the devil's snare. However, others took the opposite view. Citing Martin Luther, for example, James Ross MacDonald notes how the prominent Reformer believed that “the devil's attention was attracted not by egregious sin but by faith itself, going so far as to suggest that diabolic affliction was a sign of spiritual health" (827). ${ }^{85}$ Taking somewhat of the middle road, Calvin wrote that the devil "beset" the faithful, but "subdued" the wicked (I.14.19); while Calvin's particular language differentiates between those who are able to use faith to combat the devil and those who ultimately succumb, he nonetheless implies that both the godly and the despairing can be subject to the devil's temptations.

It was paramount that anyone who found themselves tempted by the devil refer to their faith in God's love, mercy and protection of the virtuous. Why? Because early modern scholars, theologians, and philosophers alike agreed that the devil was only ever allowed to tempt people

\footnotetext{
${ }^{85}$ MacDonald cites Heiko Augustinus Oberman's Luther: Man Between God and the Devil, who in turn cites Luther's original German translation, Kritische Gesamtausgabe, Tischreden [Table Talk], vol. 4, no. 4035: 39, 92.
} 
by God's permission, as a test of faith. ${ }^{86}$ James I argued that only by knowing the wickedness of the devil could people understand and appreciate the mercy of God (55). Baxter likewise suggests that the devils" "importunity to destroy us, should teach us the Need of the greater Care and Dilligence for our Salvation" (5). Thus, those who repudiated the devil were victorious in maintaining their virtue, but also in demonstrating their loyalty and love to God. Those who failed could nonetheless serve as didactic examples for others of the importance of maintaining virtue in the face of even the strongest temptations. Both scenarios provided dramatic fodder for early modern playwrights, who used people's hyperawareness of the devil to enact the reality of the struggle faced by Christians who sought to overcome his influence in their everyday lives.

\subsection{The Devil in Early Modern Drama}

Devils appeared as dramatic characters in forty plays between the 1570 s and the closing of the theatres in 1642 (Cox Devil and Sacred, 150). John D. Cox surmises that aside from human beings, "nothing was staged more continuously in early English drama than the devil and his minions" (4). This high volume of devils on stage was likely related to the fact that devils and the demonic remained a constant concern for Catholics and Protestants alike. However, various playwrights differed in how their devil characters functioned within their works. Cox notes that distinctly "Protestant devils" in the late sixteenth century were devices used to align the devil with Catholic ritual (85-87). Indeed, some playwrights did use human interactions with the demonic to reinforce contemporary didacticism by allowing these encounters to provide moral guidance for the audience. Often, the errors of characters on stage who gave into the devil's temptations were meant to dissuade audience members from doing the same. One such example is the downfall of Alexander Borgia in Barnabe Barnes' The Divel's Charter (1607). The play

\footnotetext{
${ }^{86}$ This is made evident by James I in Daemonologie (47), Anthony Anderson in the Shield of our Safetie (Hiv) and Richard Baxter in The Certainty of the World of Spirits (4), among others.
} 
dramatizes the story of the corrupt Borgia Pope, who, in Barnes' reimagined version, promises his soul to the devil in exchange for eight years as the most powerful man in the Catholic Church. As the seventh year of the agreement wanes, Borgia discovers that the devil deceived him about the length of time contracted - he would have only seven, not eight years. At the end of the play, when Borgia discovers not only that he has been duped, but that for all his power, he could save the lives of neither of his children, he turns to God in the hopes of saving his soul:

High God of heauens and earth if thou beare loue, Vnto the soule of the sinfull man shew mercy, Mercy good Lord, oh mercy, mercy, mercy.

Oh saue my soule out of the Lyons pawes, My darling from the denne of blacke damnation, My soule, my doue, couer with siluer wings (Sc.VI.3198-3204).

When the devil reappears to mock Borgia for his last minute repentance, and reveals that his cries come too late for the scope of his crimes, Borgia makes a direct plea to the audience to "learne wicked worldlings, learne learne, learne by me / To saue your soules, though I condemned be" (VI.3246-47). The Divel's Charter exemplifies the kind of moral didacticism Cox suggests, not only by explicitly positioning its protagonist as a tragic example of succumbing to the temptations and, ultimately, deceptions of the devil, but also by aligning devilish schemes with a key papal figure. Barnes uses his devils towards orthodox ends, as a means of revealing the consequences of turning away from God and from faith, and to encourage his viewers to continue the vigorous upkeep of their souls in the hopes of achieving salvation.

But not all early modern playwrights included devils in their drama for moral purposes, and while Cox claims that the Protestant-style devil was moulded specifically to reinforce support for the Church of England, E.K Chambers suggests that post-Reformation devils on stage represented more the increasing secularization of religious figures in drama (qtd. in Cox 9). Devils, for example, were also seen as signifiers of class and issues of social stratification, rather 
than strict ambassadors of traditional theology (16), especially as the association with the devil gradually shifted from commoners - as the poor were considered more likely to traffic with the devil to improve their own circumstances - to the elite who, like Lucifer, were particularly known for the sin of pride (208). My aim in the rest of the chapter is to demonstrate how, indeed, some playwrights harnessed the religious capital of these demonic figures in order to challenge the larger systems of belief of which devils themselves were a part. In particular, I will focus on how writers like Christopher Marlowe and Thomas Middleton manipulate the evolving role of the devil on the early modern stage to emphasize his potential to influence the psychological upheaval of characters' internal belief systems. I have cited previously how theologians like Calvin and James I are among the early modern scholars who recognized that the devil was able to literally and figuratively infiltrate a person's mind, internal and external senses. Mary FloydWilson, too, states that "no one [in early modern England] doubted the devil could affect the behaviour, emotions and actions of men and women" ("Some Fury" 72). She also claims that many sixteenth-century demonologists agreed that there were three basic levels of demonic affliction: possession, obsession and temptation — which made demonic affliction simultaneously physiological, cognitive and spiritual (74). The best way to attend to the multi-faceted nature of the devil's influence was internal examination; indeed, both Richard Waswo (71) and Kilian Schindler (120) agree that after the Reformation, hell itself was conceived of more as a state of mind than a specific place. As such, Doctor Faustus and A Mad World, My Masters are among the works that lay out for the audience's viewing how the harrowing reality of the mental struggles those who encounter the devil undergo can yet result in significant internal revelations, which serve as anchors of truth which an individual can hold on to in a world of uncertainty and unknowing. 
Aside from wondering why Hamlet hesitates, perhaps the other issue that has most captivated and confounded scholars of early modern drama is Faustus' damnation. Why is he damned? Must he indeed, be damned? Is it a matter of election or does he damn himself through his actions? Numerous scholars have ruminated on the topic, but there is a notable division of opinion — indeed because the play evades any straightforward answer, so too, the scholarship reflects the vast interpretative potential of Marlowe's work. While some scholars, like David K. Anderson and Charles G. Masinton suggest that predestination is an influential factor in Faustus' demise ${ }^{87}$ many others concentrate their discussions on how Faustus' actions (or non-action) function in his dramatic journey. Pompa Banerjee and Arieh Sachs agree that Faustus orchestrates his own damnation through his determined and intentional alliance with the devils. In her article, "I, Mephistophilis: Self, Other and Demonic Parody in Marlowe's Doctor Faustus", Banerjee argues that by "appropriate[ng] the demonic", Faustus initiates a process of self-examination that parodies the internal reflection Christians were encouraged to undertake on their journey to God $(223,230)$. However, that self-examination for Faustus reveals unsettling truths, as Banerjee claims that it "becomes a harrowing experience...because it requires a negotiation with an internal, sinister Other" (230). The Other in question is the demonic, Mephistopheles in particular, who Banerjee sees as becoming increasingly part of Faustus' very person the more involved the two become in their shared pact (228). Thus, where Christians might look inside themselves in order to find God, Faustus finds nothing but the devil because he has chosen to align himself with Lucifer and the demonic. This "harrowing" realization is what causes Faustus' despair, according to Banerjee-looking inside himself and perceiving his

\footnotetext{
${ }^{87}$ Anderson states that the "power of Marlowe's tragedy" is that both free will and predestination debates are "operative" (100), and Masinton argues that Faustus chooses magic because he sees in it a freedom which deterministic theology denies him (357).
} 
"unlikeness to God" is far more detrimental to his faith than "the taint of ordinary sin" (234). Sachs, too, discusses the reasons for Faustus' despair, and agrees that by actively choosing the devil's part, Faustus "rejects the grace offered him" and so damns himself (632). For Sachs, this rejection comes as a result of Faustus" "loss of trust in personal salvation", and so instead he courts the demonic and becomes more secure in the idea of his damnation, to the extent that he "is bewitched by the very prospect of irrevocable damnation and believes such a death to be better than salvation" (642). It is as though his fear of God's wrath and the form of His justice (632) drives Faustus to embrace his despair to the point of madness - Sachs argues that such madness is evident in the final speech, which is "imbued with a desperation that equates....salvation turned upside down" (644). We might see such perverse salvation in Faustus' claim that he will look to his God for mercy, only to cry out to Lucifer (V.ii.76-77). Both Banerjee and Sachs agree that, regardless of whether Faustus was damned from the beginning according to Calvinist election, his active choice to turn towards the demonic is what solidifies his fate. While Banerjee suggests that this choice eventually haunts him by the end of the play, at which point his self-examination reveals the hellish reality of his circumstances, Sachs implies that Faustus' headlong dive into despair allows him to evade such realization all together, as the conviction of his own damnation results in a madness that consumes him until the point that the devils come for their due.

Both scholars suggest that Faustus sets himself on a path from which he cannot necessarily turn back, as his despair, whether caused by the realization of his "sinister Other" the devil inside which seems to become a part of his very fabric - or by the fear of God whose wrathful vengeance is too formidable to face. However, there are others who suggest that despite his apparent commitment to damnation, the play itself indicates that Faustus can yet change his 
trajectory if he so chose. Joseph Westlund argues that the presence of the Good Angel makes it so that Faustus is not intrinsically cut off from heaven; but rather than alleviate despair, the angel serves to intensify it (201). ${ }^{88}$ Pauline Honderich argues similarly, that the Old Man, as a mouthpiece for the Church, serves as a reminder for "what could have been" (11). Both Westlund and Honderich suggest that the presence of the pious characters in the play imply that Faustus is not necessarily reprobate, and that he has the choice to heed the words of the purer influences who caution him against the demonic. Honderich further claims that "Marlowe endows Faustus with too many admirable and even heroic qualities...to be one of unmitigated reprobation" (11). Indeed, Jonathan Dollimore highlights the fact that it is Faustus' search for knowledge that makes him the ideal Renaissance man (Radical 323, 326), and Alfred Nuttall acknowledges that the doctor is not so far gone as to be void of remorse or regret for his sins. Nuttall claims that Faustus "clearly repents in the sense that he wishes he had not done what he has done", but his repentance lacks the "rush of contrition" that Protestants expected of those who genuinely sought God's forgiveness (30). It is evident that these scholars do not view Faustus as reprobate by birth, or even damnable by nature, but rather it is his complex and disturbing relationship to the supernatural presences in his life which prevents him from choosing a path that might have led to his salvation. Like Sachs, Honderich observes that Faustus" "capacity for fear and doubt will always prove stronger than his capacity for trust" (11). While that tendency towards doubt and skepticism may define him as an academic, these inherent psychological insecurities nonetheless inhibit him from developing trust in God and His mercy.

\footnotetext{
${ }^{88}$ Douglas Cole makes a similar argument: "the end result of Marlowe's staging of the Angels is to stress the Doctor's own will and responsibility in acting against his own best interests" (308).
} 
Douglas Cole also emphasizes Faustus' own responsibility in acting to assure his damnation. Cole argues that Faustus suffers because "he cannot escape the consequences of his human acts of mind and will, because by those acts he has eternal separated himself from the only power that can fulfill and protect his humanity" (312). I think it is significant that Cole draws particular attention to the role of Faustus' mind and his will, as I believe that what makes Faustus such an intriguing and inscrutable character is the various ways his mind and will change — are manipulated and conflicted — as he makes his way towards his final hour. Rather than focus on the religious implications of the play, other scholars have also chosen to examine the mental effects of Faustus' obsession with salvation and damnation. Kenneth L. Golden remarks that Faustus is a "victim of the splitting of the will", as he cannot ignore his desires, but neither can he escape Christianity, "especially the guilt and sense of sin that leads to despair" (203). Golden argues that Faustus' high-flying ambition in choosing to interact with the devils conflicts with his fear of what awaits him after death, to the extent that he shows himself to be both "a demi-god and a graveling self-pitying slave... at the mercy of the various elements at war within his conflicted psyche" $(204,209)$. Golden highlights the role Christianity itself plays in propagating Faustus' internal conflict, especially as it initiates the despair which the religion itself discourages; thus - if one takes the route against predestination — Christianity itself has a hand in setting Faustus on the path to damnation. As such, Golden cites Irving Ribner, who calls Marlowe's play “a protest against the religious system it portrays" (209). Genevieve Guenther also ruminates on the relationship between the habits of Faustus' thought and the Christian system of belief that dominates the world in which he lives. She notes that Faustus is "invested in the idea that spiritual efficacy inheres in the material, in bodies and texts" (46), and because he maintains this form of thinking until the end of the play, he cannot see any chance for his soul to 
find rest because he cannot imagine a form of living that is not physical (67). Guenther thus concludes that the play reveals the negativity of Protestantism, "that salvation itself entails selfobliteration into the absolute Otherness of an inscrutable God" (72), as in order to submit himself to repentance and salvation, Faustus must exchange his physical being for a blind faith in spiritual existence, which constitutes him forgoing the entire basis of his conception of self. Guenther implies that the play aligns God and religion with a fracturing of self, of the individual, that cannot both survive and be saved, and so, like Golden, she highlights how Faustus' psychological journey between salvation and damnation challenges early modern ideas of what it means to die and ascend to heaven. My own reading of Marlowe's play will build on this idea, by demonstrating how Faustus' interactions with Mephistopheles and the other devils drive him into a despair that is both spiritual and intellectual. His concern for his soul results in remorse for the loss of his mastery over the physical world, to the point that at the end, salvation for Faustus is not spiritual ascension, but a return to the natural world from which he derives his sense of self.

While some Marlovian scholars acknowledge that Doctor Faustus challenges elements of the very religious orthodoxy in which it is entrenched, most literary critics of Middleton's $A$ Mad World, My Masters make no such concession of Penitent Brothel's infamous conversion scene. In his introduction to the play, Standish Henning emphasizes the "defective" nature of the scene, which is "jarring because it suddenly introduces the paraphernalia of standard morality into an action which has been trying to avoid it" (Middleton, xii). For Henning, because Penitent's remorse comes on unexpectedly, "we are left with an impression of earnestness unsupported by creditable incident and character" (xii). The result, Henning argues, is that the speech is "stiff and self-conscious... as if Middleton's esthetic senses were instinctively balking at the forced, 
contrived morality which has no organic place in his world of rogues" (xv). I think Henning's assessment overlooks two significant factors, the first being the very nature of Penitent's character as he is introduced to the audience at the start. The dual implication of his name, Penitent Brothel—upon which I will elaborate in my reading of the play—suggests that standard morality is not outside the scope of his character, as he is penitent before he is bawdy. And while his scheming with the courtesan towards adulterous purposes might undercut this nominal interpretation, Penitent himself demonstrates moral concern and the kind of internal examination encouraged by Christian authorities. He does his from the start of the second act when he scorns his own hypocritical tendency towards judgement when he himself is so flawed (Middleton I.i.90-95). Arguably, this veritably penitent Penitent makes only a brief appearance, as he is soon subsumed by his lusty pursuits, but the very fact of its appearance makes it so the later conversion is not totally out of character. ${ }^{89}$ As such, his re-turn towards critical self-examination is more believable than Henning suggests. Secondly, Henning implies that the jarring nature of the conversion scene makes it foreign to the rest of the play; yet, such a dismissal seems to forget the shocking reality of the scene itself. Penitent, after all, encounters a succubus, a supernatural being that evidently fills him with doubt and fear. The scene, I argue, is supposed to be jarring in order to reflect the tone of Penitent's experience, and it is only because the encounter elicits such discomfort and uncertainty that it is so effective - both on Penitent and on the audience.

Other scholars take a similarly skeptical approach to the merit of the conversion scene because of the difficulty they have reconciling it with the rest of Middleton's play. Both William Dunkel and Derek Alwes agree that the scene evades sincerity-for Alwes, it is too "awkward" to do so (101) while Dunkel argues that it is presented "so unempathetically...that the audience

\footnotetext{
${ }^{89}$ Robert Root Jr. also notes that in his first speech, Penitent "establishes the somber tone that will occur again with the succubus" (85).
} 
probably related to the scene as comic stuff" (qtd. in Root Jr. 86). Herbert Jack Heller cites a slew of scholars who explicitly dismiss any noteworthy critical significance in Penitent's conversion: Michael Shapiro calls the show of repentance "sleazy [and] self-righteous" (qtd. in Heller 40); P.K Ayers describes the conversion at the hands of the succubus as "a grotesque intrusion of the supernatural apparatus into a domestic context... a kind of deconstructive joke that turns reality for the audience inside out" (qtd. in Heller 42); George E. Rowe claims that since Mad World is a play of "meaningless forms....the repentance participates in the general meaninglessness of the worlds or forms in which they are portrayed" (qtd. in Heller 55). Evidently, the common scholarly opinion is that the conversion scene is not to be taken seriously, nor analyzed as a genuine turn towards morality; Ayers outwardly states that Middleton manipulates "morality-play conventions [to point] to their lack of significance in 'modern' drama, and thus ultimately to the irrelevance of conventional patterns of beliefs and behaviours to life in the city" (qtd. in Heller 42). Indeed, all of the aforementioned scholars discredit Penitent's encounter with the succubus and the consequent remorse for his actions as an unconvincing religious conversion. But I believe that this interpretation is limited by seeing the conversion strictly as religious. More-so than his ruminations on morality, one of the most startling elements of his repentance speech is his shifting attitudes towards women, upon which I will elaborate in greater detail in my analysis of the play. Not only does he take full accountability for initiating the adulterous affair with Mistress Harebrain, but he extends responsibility to all men for their ill treatment of women, the result of which is an overly sexual—therefore immoral—stereotype that women themselves do little to promulgate. There is a realignment of beliefs in the gender hierarchy—a gender(ed) conversion, shall we say—which 
goes unnoted in much of the scholarship on the play, and it is this conversion which will be the focus of my own reading.

In addition to doubting the sincerity of Penitent's conversion-whichever conversion that may be-many scholars tend to deny any correlation between his apparent epiphany and the encounter with the succubus. Robert Root Jr. claims that Penitent has already decided to end the affair with Mistress Harebrain prior to his supernatural interaction, and so the succubus "merely tests his resolve" (85). Charles Hallett argues similarly, that because Penitent has already chosen to reform, "the succubus does not affect [his] conversion at all" (80). Like the other scholars discussed above, Hallett and Root Jr. base their arguments on the assumption that Penitent's conversion is only moral, religious. However, Penitent's thoughts on gender roles and responsibility change drastically after his encounter with the succubus. As I hope to demonstrate, the monologue where he decides to end the affair nonetheless puts the blame for the affair largely on Mistress Harebrain, while spouting popular stereotypes that depict women as fickle and immoral. But after his shocking encounter with the she-devil, Penitent recognizes his own role in facilitating the immorality for which society then demonizes women alone. This is the shift in thinking, the reassessment of conventional belief and cultural stereotypes, which the encounter with the succubus prompts in Penitent, and this is the more fascinating conversion, I argue, which many other scholars problematically overlook.

Literary critics of both Doctor Faustus and A Mad World, My Masters tend to focus their scholarship on the religious, moral dilemmas facing Faustus and Penitent Brothel, respectively. In the sections that follow, my aim is to demonstrate that viewing these characters through this limited scope risks ignoring the larger psychological impact that overarching power structures like religion - and gender-have on those caught up in them. Furthermore, it is my contention 
that the mental journeys of these characters are facilitated through encounters with the supernatural which, rather than being mere tropes to reinforce moral doctrine, force characters to confront, and resist, the difficulties that these structures impose on those dominated by them. In this way, Marlowe's and Middleton's works prove more critically reflective than contemporary pamphlets about similar supernatural encounters which, like the scholarship cited above, frame these interactions through a moral lens - the cost of which is the dismissal of key psychological insights that can help us understand the various factors which shape and alter early modern belief.

\subsection{The Doctor and the Devil}

On May 26 1674, in the town of Badger-Alley in the Shoreditch district, Jane Oxly "fell into a most lamentable Condition of horror and despair, Crying out that she was Damned to all Eternity, and that there was no hope of her salvation". ${ }^{90}$ She revealed the reason for her statesix years earlier, "being very poor and in a disconsolate condition", she encountered the Devil, dressed as a gentleman, and surrendered herself to him. He had offered her money in exchange for her servitude, "to which she consenting, he prickt her hand or Arm with a pin, and drawing some blood, he therewith wrote a Contract." On the May date of her despair, she had but six weeks remaining in her contract, after which she "would be hurried away into Everlasting Flames of Fire and Brimstone." A minister was brought to Miss Oxly, to whom she might confess her sins and so seek forgiveness from God. She did confess to debauchery and

\footnotetext{
90 This encounter is taken from the anonymous record, Strange and terrible news from Shoreditch of a woman that hath sold her self to the Divel; living in Badger-Alley; and lying at this present in a sad and miserable condition; acknowledging that about six-years since, she made a contract with the Divel written with her own blood, and that her time wasnow, expired within six weeks; and she irrecoverable to all eternity; with the like speeches of dispair. As also, how several able ministers went to comfert her, with her full confession of her former evil life, and other passages between them. With allowance, 1674, Wing (2nd ed.) / S5831A, EEBO. 23 Aug 2018.
} 
defrauding her neighbours - a husband and a wife. She bewitched herself to swallow pins and needles, but blamed them, accusing the couple of trying to get her to injure, or even kill, herself, and so had them falsely imprisoned for witchcraft. But though the minister assured her that confession and repentance "set[s] forth the inestimable riches of God's grace" to the worst sinners, she insisted that because she had renounced God for the Devil, there was no hope of salvation for her.

The anonymous author of the pamphlet uses the case of Jane Oxly to warn against the dangers of religious despair, "a sin that refuses all means of Deliverance...a kind of unkind Ingratitude to Heaven" because those afflicted wrongly come to believe that as they "offended without Remorse, so they should be convicted without Hope... [that] even Infinite Mercy cannot pardon them". Miss Oxly exemplifies the utter hopelessness of such despair, as she cannot accept the possibility of redemption, even when the minister uses the example of Mary Magdalene, "having as many as seven devils cast from her" to encourage her otherwise. In the aftermath of the Reformation, despair was considered not only a sin in itself - the "unkind Ingratitude to Heaven" to which the pamphlet refers — but also a result of believing oneself to be reprobate (Sachs 628). Article seventeen of the Church of England's Thirty-Nine Articles indicates similarly, that those who believe in their own reprobation were often "thrust into desperation or wretchedness" (C2). Thus, people demonstrated their ungodliness by allowing their potential reprobation to lead them into desperate and wretched behaviour, thereby inadvertently justifying their reprobation. Instead, Calvin writes in his Institutes of Religion that "when they [people] enquire upon predestination they pearce into the secret closets of the wisdom of God, whereinto if any man do carelessly and badly break in, he shall both not certaine wherewith to satisfie his curiousnesse, and he shall entre into a mase whereof he shall finde no way to get out againe" 
(381). Thus, the individual punishes himself, condemns himself to a state of despair, by seeking to know that which is beyond his ability to know. Despair was, therefore, both sin and punishment, so those who entered into it were caught in a Sisyphean struggle wherein their sin breeds further sin by their very reactions to the original vice. The idea itself leaves little room for the afflicted to escape, so it seems an appropriate state for the non-elect, for whom even repentance was not guaranteed to prevent eternal damnation. But, as Arieh Sachs notes, falling into despair often sealed a damned fate (629).

As I discussed in the previous section, several scholars have speculated that it is the belief in his own reprobation which prevents Marlowe's Doctor Faustus from turning towards God, despite having several opportunities to do so. Robert Ornstein suggests that Faustus' inability to repent and potentially save his soul stems from an egocentricity which prevents Faustus from submitting himself to God in the way true repentance requires (1384). On the contrary, Miss Oxly demonstrates at least the attempt to save herself in a way Faustus does not, as the pamphlet reveals that despite her reluctance to embrace the minister's teachings, she nonetheless says the Lord's prayer repeatedly with him, which "she seemed to do with fervency and affection". While it might seem like this turn towards God signifies the victory of the power of good over the devil's influence - thereby justifying the path of righteousness set out by Protestant ministers and their ministries - the conclusion to the Oxly pamphlet is more ambiguous than the initial moral framework suggests. For, while Miss Oxly does indeed turn towards God through prayer, the author never explicitly states that she repents her sins, only that she confesses them. Faustus, too, verbally admits his error in signing away his soul, ${ }^{91}$ though he never properly asks forgiveness for doing so.

\footnotetext{
${ }^{91}$ See V.ii.39-40 [A text]: "For vain pleasure of twenty four years hath Faustus lost eternal joy and felicity. I writ them a bill with mine own blood".
} 


\section{Despairing of Damnation}

But, the Oxly pamphlet nonetheless leaves off in a more hopeful tone than Marlowe's play, despite her ongoing despair. At the end, Miss Oxly calls the minister back for a final confession, during which she reveals that "she should never be satisfied till she had seen and spoke with the old man and his wife in the Country whom she had wronged". Despite her continuous avoidance of repentance, Miss Oxly shows signs of life and moral concern beyond despair, seeking to right the wrongs she committed before the devil comes to claim her. The pamphlet's final lines state that a letter was carried to the couple from Miss Oxly, indicating that she would testify against the charges laid in order to procure their freedom (8). Regardless of whether she was, in fact, damned, these final sentiments of remorse demonstrate that Miss Oxly was not totally consumed by her despair to the extent that she could not yield to her conscience, or acknowledge the plights of others. She may not have turned towards God, per se, but she nonetheless exuded the spirit of goodness, and even mercy, for which God Himself stands. This is significant for several reasons. First, it is telling that Ornstein notes that Faustus' inevitable damnation appears all the more disturbing as he seems to become more morally conscious towards the end (1382) — so it is with Miss Oxly, whose increasingly remorseful sentiments make her appear more sympathetic despite her original contract with the devil. For a pamphlet that begins by decrying the state of despair as a sin against Protestant belief, the record ends with a subtle, though likely unintentional challenge to that same faith, which would persuade those who may, in fact, be saved, of their own irrevocable damnation. Furthermore, the pamphlet's initial warning against despair seems somewhat at odds with Miss Oxly's final sentiments, which is particularly problematic considering her story is meant to serve as a case study for the author's overarching didacticism. If despair is a horrible sin because it demonstrates "ingratitude to 
Heaven", how are we to reconcile the Christian values that Miss Oxly exemplifies through her concern for those she has wronged? Does such concern not suggest a yielding towards heavenly virtue, rather than a forsaking of it? It is telling that she is able to remember Heaven in this way while nonetheless feeling distant from it, as her despair never seems to leave her. Her ability to possess both complicates the image of despair which the author provides as a kind of allconsuming state of torture, void of thoughts of mercy or hope. Instead, we get a portrait of a woman who is very much engaged in mercy — if not for herself, then for others — and whose story ends with the potential for hope, which the pamphlet itself does not acknowledge or explore. Rather, the author ends with an ambiguity that ultimately complicates the work's original purpose, as the moral lesson with which it begins fades into the background, and instead it is the intriguing complexity of Miss Oxly's mental disposition in this state of despair which leaves the most striking impression.

While the Oxly pamphlet hints at the problematic contradictions and complications inherent in Protestant ideas of predestination and despair, the author nonetheless insists on his original framework by not recognizing these elements of the story. In Doctor Faustus, however, Marlowe highlights these theological difficulties. ${ }^{92}$ It is evident from the mass of scholarship on the religious significance of the text, some of which I reviewed in the previous section, that the

\footnotetext{
${ }^{92}$ My analysis cites the A-text of Marlowe's play Doctor Faustus (published in 1604, though thought to be written and first performed in 1590). Scholars have disputed whether the A or B text is more in line with Marlowe's intentions, but I am interested in the psychological ambiguity of the A-text, where Faustus' fate seems less certain and so his own internal ruminations play a significant role in determining, both for himself and the audience, the ending he deserves. For example, in the B-text, Faustus often refuses to name God specifically, as he does in the Atext; instead, the magician refers to an ambiguous "he", demonstrating less engagement with the divine and, subsequently, possibilities of his salvation. James Ross MacDonald claims that the A-text's ambiguity also allows it to be more critical of Protestantism (839), which aligns well with my own reading of the play. Somewhat contrarily, Leah Marcus argues that the A-text is more directly framed by Protestant rhetoric, especially as it places Faustus not in Wittenberg, but Wertenberg - an area along the Rhineland known for its militant Protestantism (qtd. in Marlowe 156). However, Marcus also claims that the A-text "places the magician at the extreme edges of transgression" of its Protestant framework (159), which further coincides with Ross-MacDonald's claim as well as my own argument.
} 
play evades any concrete stance on ideas of election or faith. It is true that the fate of his soul has a large influence on Faustus' psychology throughout the play. ${ }^{93}$ But, I argue that by having Faustus obsess over his eternal fate, Marlowe highlights the human difficulty of trying to accept spiritual unknowing in a time so focused on learning, exploration and discovery. In his book, Being Protestant in Reformation Britain, Alec Ryrie notes how Protestants were largely plagued by fears of their own damnation, especially as ministers emphasized the fear of hell more than the hope for mercy as a way to ensure the obedience of the congregation $(28,33)$. Furthermore, while these same ministers warned against falling full-on into despair, they nonetheless agreed that the temptation to despair could be "spiritually fruitful" (32), as it could encourage people towards repentance and conversion. The Oxly pamphlet echoes this idea, as the author states "but as soon as ever the Conscience is awakened by the Terrours of Divine Justice, then that he may divert them from a sincere Repentance and Conversion to God" (3). Protestants, therefore, were required to walk a fine line along the verge of despair-allowing themselves to experience the terrible possibility of their own damnation, while nonetheless continuing to act as to be worthy of divine grace (even if their natural reprobation should be unable to reward such action). The idea of despair thus imbued one with a kind of split identity, expected to fulfill two opposing versions of self that risked conflicting with and/or overtaking one another. The Oxly pamphlet is able to reconcile this internal division by having Jane remain convinced of her own damnation — she never considers the possibility of salvation, and so her compassion for others occurs in spite of her despair rather than in the hopes of being saved. Nonetheless, her virtuous turn complicates the nature of despair as theologians conceived it, as her demonstration of Christian morality

\footnotetext{
${ }^{93}$ For reference, see such articles as Genevieve Guenther's "Why the Devils came when Faustus called them." Modern Philology, vol. 109 no.11, 2011, pp. 46-70; Constance Brown Kuriyama's chapter on Faustus in Hammer or Anvil: Psychological Patterns in Christopher Marlowe's Plays; and Sara Munson Deats' "Doctor Faustus: From Chapbook to Tragedy". Essays in Literature, vol. 3, 1976, pp. 3-16.
} 
despite having fallen on the wrong side of it makes her sympathetic, and consequently, reflects poorly on the writings that would persuade her of her own damnation. However, due to its ideological constraints, the pamphlet cannot fully indulge the implications of this implicit challenge to the complicated nature of the relationship between religious despair and election.

\section{A Battle of Mind and Spirit}

Unlike Miss Oxly's resignation, Faustus' interaction with the devils catapults him into a psychological tumult over his eternal fate- he oscillates between accepting, even embracing his reprobate state, and contemplating repentance in an effort to restore his salvation. In his own despair, Faustus' plight echoes the crisis of split identity of other early modern Protestants; indeed Sachs suggests that Faustus "exemplifies the convention that reprobate despairers suffered from a 'divided' psychological state, an inner discord which reflected the discord they brought to the world" (644). However, I argue that the psychological conflict Faustus experiences is two-fold: it is both a religious despair for the fate of his soul, but also an intellectual despair, which I define as his psychological difficulty to reconcile unknowable spiritual truths (like God and heaven) with his own process for acquiring and mastering knowledge - which is based in study of the physical world. Faustus is, therefore, divided not only between salvation and damnation, but also between the earthly and after-lives. Throughout the play, Marlowe parallels the two by figuring both religious and intellectual despair as similar crises of identity, and by rooting Faustus' understanding of the spiritual afterlife in his focus on the physical world. Faustus simultaneously takes both the spiritual and the material worlds for granted, as he seeks to use magic to exceed disciplines rooted in empirical study which he believes he has already academically mastered. However, while Faustus begins by treating the occult as another subject based in materiality that he can easily absorb, his interactions with 
Mephistopheles reveal his error: that the spiritual is in fact beyond the scope of the mind's comprehension. More significantly, the appearance of the devils sets Faustus on a psychological collision course, where his religious despair for his soul both occurs alongside and comes up against his despair at losing his capability for earthly mastery. The more he engages with Mephistopheles, in order to persuade himself that he yet maintains the capability for mastery in which he anchors his selfhood, the more he discovers his spiritual and intellectual frailties. Faustus' build-up of uncertainty comes to a head in the eleventh hour, when his concerns about the afterlife dissolve into thoughts of the natural world - the elements on which he once focused his studies. At the end, Faustus looks not to Lucifer or God, but to the earthly to shield and comfort him. The full circle return of his focus to empirical matters suggests that if Faustus could indeed return to the first act, he would be best served consuming himself with his earthly life—as the uncertainty of one's fate in the afterlife can engender a debilitating internal struggle which, in the end, he can do nothing to resolve for certain.

When the audience first meets Faustus, he is trying to "settle [his] studies" (AI.i.1), and he presents a catalogue of accomplishments in subjects he has mastered. His language is reflective of his conviction in his own abilities; of analytics and logic as well as medicine, Faustus claims he "hast attained the end" (AI.i.10, 18). He further trivializes the pursuit of law as "paltry legacies" (30). ${ }^{94}$ The flippancy with which he dismisses each discipline speaks to the surety, even to the point of arrogance, of his certainty in his own academic ability, particularly when dealing with materiality (the physical body as the "end" of "physick" (17), commercial exchange as the aim of legal study (28-29) etc.). He looks specifically to tangible proofs of his

\footnotetext{
${ }^{94}$ Faustus associates the study of law primarily with matters of exchange, which is evident when he says, "Si una eademque res legatur duobus, / Alter rem, alter valorem rei, etc." (28-29), which is translated by editor David Scott Kastan as "if one and the same thing is bequeathed to two people, one should have the thing itself and the other the value of the thing, etc."
} 
own mastery, referring specifically to the "bills hung up as monuments" (AI.i.20), for example, as evidence of his medical expertise. While the fact that Faustus seems to miss the emotional, indeed human, significance of his accomplishments may call into question the degree to which he can be understood to have true knowledge, for the purposes of my argument, it is enough that Faustus himself believes in his own mastery, regardless of whether the play subtly undermines it. The belief in his own capability to acquire knowledge is evident in his constant use of action verbs in this first monologue: "Faustus...begin ... to sound the depths of that thou will profess/ ...be a divine... / live and die" (1-5, emphasis mine). All of the verbs he uses are in the active present, if not future, to emphasize the credit he gives himself for achieving his own desires. The importance of this active speech, which at the beginning of the play signifies Faustus' belief in his own capability for mastery and knowledge, will become more apparent in a later section when I discuss how the entrance of Mephistopheles changes the way Faustus views this capability, as evidenced through a decline in the certainty of his language.

Some scholars have suggested that the confidence Faustus exhibits in the first half of this monologue wavers when he comes to the subject of theology, particularly when he famously, arguably intentionally, misquotes the verse from the Gospel of John. He emphasizes that "we must sin and so consequently die / ... an everlasting death" (AI.i.45-46), but omits the succeeding verses about redemption through repentance. Joseph Westlund argues that Faustus' use of hyperbole here inhibits him because "he makes things worse than they are", which further demonstrates "his inability to believe in the grace and the salvation of Christ" (194). However, to assume his misquotation is an indication of his belief in his own damnation is to overlook Faustus' capability for academic mastery. Rather than suggest that his biblical omission is a sign of his internal hopelessness, I argue that it represents the height of his linguistic manipulation-a 
feat he is only able to achieve because of the training he has received. I believe Rebecca Lemon is correct when she writes that in this scene, "Marlowe intends to call our attention to Faustus' deliberate violation" of the text (881), because of what it reveals about his linguistic and rhetorical mastery. Faustus does not finish the verse because he fails to remember it, or because he sees no hope in it, but because only the first part serves his purpose, which is to justify the turn towards the occult when theology would caution against it. Here, it is evident that Faustus engages in what Sara Munson Deats refers to as "willful self-deceit" (4), which he is only able to do because his theological training has provided him with the expertise necessary to manipulate the Scripture for his own devices. Furthermore, he enters into this self-deception intentionally, indeed willingly, largely because it is a space of his own making, an intellectual fabrication that he can create and control.

However, Faustus errs in presuming that magic will be another one of those arenas in which he can excel, on account of his ability to master academic fields rooted in the study of the physical world. He speaks of the occult in the same kind of terms he uses in his previous catalogue, emphasizing the "lines, circles, scenes, letters and characters," for "these are those that Faustus most desires" (AI.i.51-52). He treats the occult as another kind of empirical study, highlighting not its supernatural potential, but the linguistic, visual, material aspects which aligns it with the academic disciplines to which he is accustomed. He further refers to the practitioner of magic as a "studious artisan" (55), and tells himself to "try thy brains to gain a deity" (63). The repeated emphasis on study as a way to gain knowledge about, and so master, the world, reveals that from the beginning this is the realm in which Faustus anchors his certainty of selfboth he and the play define him according to his capability for mastery of earthly knowledge, and it is through the physical and the material that Faustus sees and understands the world and 
his place in it. His interest in magic similarly stems from his desire to increase his academic knowledge about the natural world, as well as his power over and in it:

Emperors and kings

Are but obeyed in their several provinces,

Nor can they raise the wind or rend the clouds;

But his dominion that exceeds in this

Stretcheth as far as doth the mind of man. (AI.i.57-61)

Faustus specifically highlights that he wants to supersede rulers who have dominion in only a few areas of the world. By contrast, he desires power across the natural world, including control over its atmosphere. It is telling that he seeks only to "exceed in this"- that is, in the realm of the natural, material, earthly and human—rather than to simply exceed, or excel beyond, the world he knows. Why, for example, does he not consider venturing beyond his immediate surrounding, to explore the unknown universe? He engages in discussion with Mephistopheles about the cosmos, but never asks to observe them for himself. Rather, he looks for Mephistopheles to merely verify the theoretical ideas he has already encountered in his study. He asks questions about the shape and movements of the planets, but then haughtily mocks, "Tush these slender trifles Wagner can decide. / ... / Who knows not the double motion of the planets?” (II.iii.49, 51) It becomes evident that Faustus is looking for answers that reaffirm his own pre-existent knowledge - another way for him to revel in his own intellectual mastery. It is in this realm of certainty in his own mastery that Faustus finds psychological stability. However, once he is confronted with possibilities that catapult him outside the arena of what can be known through empirical study, that sense of self-security that he finds in the earthly begins to dissipate; ultimately, his own destruction comes not as a result of choosing hell over heaven, but of not pursuing knowledge of himself through continued study of the human world, the realm in which his identity is rooted. 
While scholars like Westlund imply that Faustus' misquotation of Scripture is a result of his despair, I believe that Faustus only begins his descent into despair once he encounters Mephistopheles, for it is only after their first encounter that he appears genuine in worrying about the fate of his soul. This sudden concern with his damnation coincides with his increasing frustration as Mephistopheles forces him to consider otherworldly concepts, truths which Faustus cannot understand because he has not experienced them previously. When he asks Mephistopheles, "Tell me, where is the place that men call hell?" (AII.i.112) it is evident that he is looking for answers about a specific locale, one he can imagine by associating it with other such places he has experienced. This is yet another example, not unlike his questions about the cosmos, where Faustus seems to seek a response he can reconcile with his pre-existing knowledge. It is for this same reason that he asks Mephistopheles to "tell me who made the world?" (II.iii.65), despite the fact that, as a doctor of divinity, he is well aware of the answer. As with his inquiries into the movement of the planets, here Faustus desires to use magic and the occult to augment his confidence in his own ability to know. As such, he expects to hear about a hell that is, as Genevieve Guenther suggests, "an extension of the university" (60) or some such place that he can mentally locate, of which he can visually conceive-perhaps the den of fire and brimstone that Jane Oxly describes in anticipation of her own damnation. However, he receives an unsettling response from the devil: "Hell hath no limits, nor is circumscribed / In one self place, for where we are is hell, / And where is hell, there we must ever be" (AII.i.117-19). Mephistopheles implies that hell is not a place, but a state of mind, which one cannot necessarily envision, but only feel—only experience when suffering it. His metaphysical answer seems to disturb Faustus, whose identity is anchored not in higher concepts - recall that he treats even theology as an academic discipline — but in empirical, worldly ideas. This disruption to Faustus' 
conventional way of thinking is evident in the fact that he immediately dismisses Mephistopheles' description: “Come, I think hell's a fable / ...these are trifles and mere old wives' tales" (AII.i.123, 131). Despite Mephistopheles' insistence that "I am an instance to prove the contrary" (132), Faustus declares they should "leav[e] off" (135-36) the subject, and immediately proceeds to ask the devil for a wife. Angus Fletcher observes that "[Faustus'] denial stems from a frustration at the inability to comprehend the afterlife because he himself is not yet dead, so he dismisses Mephistopheles' replies about hell" (192). And while it is likely that Faustus may have come across this idea of hell as a psychological state during his theological training, his insistence on an exact location reads quite like his former scriptural omission wherein he consciously overlooks any information that risks undermining the coherency of his own psychological perception.

Faustus rapidly moves from ideas which extend beyond what he can know through study when he asks Mephistopheles for physical books, "where I might see / All characters and planets of the heavens, /.. / . . wherein I might see all the plants, herbs and trees that / grow upon the earth" $(165-66,170-71)$. His focus quickly rebounds from truths he cannot reconcile with earthly matters, topics concerning study of the physical, visual world. Kirsten Poole notes the irony in the fact that Faustus "maintains a detached cynicism about the existence of hell even as he has personally signed a demonic contract and conversed with devils" (204). The reason for this, I argue, is that the contract and the devils are concepts that Faustus can absorb visually, and so mentally grapple with, as opposed to Mephistopheles' description of hell which is metaphysical and abstract, and denotes an ongoing doomed existence which Faustus cannot fully understand, nor wants to. It is an absent presence that eludes the physical context of knowledge in which he anchors his sense of self, and so he mistrusts the idea, despite Mephistopheles' credible 
insistence, because attempting to wrestle with it would constitute shaking the psychological foundations of who he is, to the point of total collapse.

Michael Hattaway similarly notes that throughout the play, Faustus does not believe in anything he cannot sense, and Mephistopheles is able to steer Faustus away from thoughts of repentance by "keep[ing] his senses gratified and his mind diverted" (68). This is evident the first time Faustus seriously considers, "is't not too late?" (AII.iii.74) to turn back to God, and Mephistopheles returns with the parade of the seven deadly sins - to which Faustus responds, "that sight will be...pleasing unto me" (100, emphasis mine). The emphasis is again on the visual when, at the end of the parade, he exclaims to Lucifer, "oh might I see hell and return, how happy / were I then!” (163-64); for Faustus, to see hell would be to quell any mistrust he felt earlier during Mephistopheles' original description of it, because the sensual experience of it would allow him to observe hell, to study hell, and so conceive of it in the manner on which he relies for psychological certainty. It is also significant that Faustus desires to live to see hell and return intact, and Guenther argues that by being able to visualize hell as a familiar place (the aforementioned university), he believes that he can "secure for himself an eternity of continued embodiment" (65). By imagining hell as a geographical location he might visit, Faustus fantasizes a perpetual physical existence where his actions, including his contract with the devil, lack any real consequences for his soul. In this way, he attempts to bypass his intellectual despair by asserting his material view of the world in order to ease his religious despair as well.

\section{A Matter of Sense}

Guenther astutely observes that "the spirits actually give him hope that he might remain embodied after death" (66), as Lucifer responds to Faustus' desire to return from hell by saying "thou shalt" (A.II.iii.165), and even the implied possibility that he might evade the reality of his 
mortality is enough for Faustus to continue to favour the devils over the idea of repentance. But why are the devils able to infiltrate Faustus' psychology so powerfully? In sixteenth-century England, it was accepted belief that devils had the ability to manipulate the inner senses in order to produce illusions (Clark Demons 125). In the Summa Theologica, Thomas Aquinas reiterates as much, that devils could work within human senses, both external and internal (consisting of the will, appetite, imagination ${ }^{95}$ etc.), and alter the humoral balance to effect phantasmata, ${ }^{96}$ and so create a "semblance of reality" (xv.15-17). Reginald Scot refers back to Aquinas' doctrine in the Discoverie of Witchcraft, when he writes that one of the most common ways the devil afflicted people was "by deluding as well their sense of feeling as seeing, which is not impossible to him to do, since all our senses, as we are so weak...will often times be deluded" (52). In line with Hattaway's argument, it is apparent that Scot's determination that the devil focuses specifically on the visual is particularly applicable to Faustus, as the parade of sins is but one way Mephistopheles tries to divert Faustus' attention with visual spectacles in order to keep his mind off the fate of his soul. At the moment that Faustus is warned by his own blood to discard Mephistopheles_- “Homo fuge!" (AII.i.80) — the devil immediately seeks to distract Faustus from further contemplating the disturbing message: "I'll fetch him somewhat to delight his mind" (81). Mephistopheles return with devils who give Faustus various gifts—material riches to peak his visual interests, and "show [him] what magic can perform" (84), while steering his thoughts away from the spiritual consequences of using that magic.

\footnotetext{
${ }^{95}$ Guido Giglioni also discusses how demons were tied to the human imagination specifically, and could manipulate the imaginative faculty to trick man's more rational nature (22).

96 “Aristotle describes phantasmata as being analogous to paintings or wax impressions (De Memoria 450a-b), and as 'a residue of the actual [sense] impression' (De Insomniis 461b; cf. Rhetorica 137a 28) or 'a movement resulting from an actual exercise of a power of sense' (De Anima 429a 1-3). Aristotle believed these inner, psychic appearances were central to how we recall memories, as well as to how we perceive the immediate world around us (https://plato.stanford.edu/)
} 
Clifford Davidson argues that the devils succeed because they are able to cater to Faustus' will and in doing so supersede his cognition. Cognition was the faculty by which "men perceive and understand" the world — the faculty which, I argue, dominates Faustus' selfhood—while the will (also referred to as appetite or affection) was "that by which we either resist or follow after the things known" (Davidson 518). ${ }^{97}$ Mephistopheles manipulates Faustus' propensity for physical knowledge by tempting him with visual spectacles that entice his sensual understanding — a pull that resonates so strongly with Faustus because the material, visual world is where he feels most secure. The devil's influence is evident in the way Faustus yields to his suggestions. When the pair first arrives in Rome, Faustus confesses "I do long to see the monuments / And situation of bright, splendent Rome / Come, therefore, let's away" (AIII.i.4648). But, when Mephistopheles insists "Faustus, stay" (49), he concedes "Well I'm content to compass then some sport / And by their folly make us merriment" (53-54) —not long before, he seemed excited at the prospect of "his holiness bid[ding] us welcome" (26), as though anticipating being guests of the Pope at dinner. But at the suggestion of Mephistopheles, Faustus' initial, almost absent-minded, reverence towards the Pope evolves into a willingness to make a fool of him, and he puts aside his desire to sight see in order to engage in petty trickery. Faustus allows his will to be directed by Mephistopheles with the promise of being able to show off his newly acquired skills — the kind of visual reward that resembles the empirical evidences which define his initial confidence in his own abilities. Yet, the irony is that this magic is trivial

\footnotetext{
${ }^{97}$ John Beaumont in his Historical, Physiological and Theological Treatise of Spirits, Apparitions, Witchcraft and other Magical Practices (1705) cites Dr. Thomas Willis, who differentiates between the Corporeal Soul and the Rational Soul, stating that "the Corporeal Soul does not so readily obey the Rational in Desirables, as in Know[ledge]... and so having more intimate Affinity towards the Flesh, its wholly bound to take care of the good and Preservation of that" (317). This indicates that, as Davidson suggests, the needs of the body are likely to overtake reason in cases of desire — including the desire for knowledge — so Faustus' desire towards sensual understanding seems to overtake his more rational sensibilities even to the point that he forsakes his cognition, knowledge of what he can know for sure, and allows himself to be enticed by Mephistopheles' visual shows.
} 
compared to the once lofty visions Faustus had for his occult knowledge, and by giving into the devil's lure for such underwhelming results, Faustus sinks himself deeper into submission, and damnation, and further from the mastery he exhibits at the start of the play.

\section{Faustus'Soul Concern}

However, just as Jane Oxly is able to retain her individual sense of justice in the face of her despair, so Faustus' rational cognition reappears in moments where he doubts the decisions to which his will has lead him. These moments suggest that, just as Miss Oxly's despair is not all-consuming of her character, neither is Faustus totally subsumed into the devilish spectacles he falls prey to time and again. Rather, these moments of second guessing his contract with the devils and of considering repentance demonstrate that Faustus' cognition yet lurks beneath the dominant will, and that there is still some of Faustus' former intellectual scepticism in him to combat his total submission to hell and its forces. Furthermore, his reconsideration of his pact with the devil resembles the second half of the despair paradox, wherein one on the verge of such was expected to act as though they were saved. Here, despite, like Miss Oxly, already having entered into despair, Faustus' intermittent shows of remorse at selling his soul suggests that God might save him, too, in the end. However, these moments of doubt also manifest the psychological uncertainty that Faustus begins to feel as soon as he encounters the devils. While this uncertainty may act as a kind of resistance to hellish enslavement, it nonetheless demonstrates the psychological tumult which results from the obsessive contemplation about the eternal fate of the soul. His mental conflict is most apparent in the form of his language, particularly in moments where his focus shifts sharply between banalities and weighty thoughts of eternity. These stark psychological turns manifest largely towards the end of the play, as Faustus becomes increasingly conflicted between his desire for earthly knowledge and his fear of 
damnation. One such shift occurs in the first scene of Act Four during Faustus' interaction with the horse-courser. His playful mood suddenly turns aggressive; he changes from immersing himself in the joke at the horse-courser's expense, warning him not to ride the horse in the water (AIV.i.121-23), to showing unexpected agitation: "Away you villain! What, dost think I am a horse-doctor?" (A130) His use of exclamation and his inflammatory language against the unsuspecting horse-courser indicate a sharp alteration in tone, which seems to reflect the transition of his thought from the trivial joke to the fate of his soul; for, in the next line, Faustus embarks on an existential contemplation: "What art thou, Faustus, but a man condemned to die?" (131) It is as though he tires of his game, recognizing it to be a mockery of the kind of magnificent works he had once hoped to achieve with magic, and so his diminished sense of mastery over the physical world around him, the manifestation of intellectual despair, sparks a renewed contemplation of his religious despair as well. ${ }^{98}$

This sudden shift from psychological stability in his own self, and his own capabilities, to uncertainty both in his aptitude for mastery and in regards to the afterlife of his soul, is evident also in the evolution of his linguistic content. As discussed previously, Faustus in the first scene of the play speaks with an air of arrogance while listing his academic accomplishments. For this Faustus, the occult is just another subject, much like theology, that he can conceive in terms of his own conceptions of knowledge by focusing on the lines, the characters, the words on the page. However, once he meets Mephistopheles, even before he actually signs the contract,

\footnotetext{
${ }^{98}$ Another notable shift occurs in V.i just after the Old Man leaves Faustus, and he reflects on damnation and the possibility of repentance: "Accursed Faustus, wretch, what hast thou done? / ... / What shall I do to shun the snares of death" (64-67). However, after Mephistopheles appears to scold him for his betrayal, just three lines later Faustus turns, "I do repent I e'er offended him [Lucifer]" (71). His rapid switch arguably occurs because of Mephistopheles' threat to "tear thy flesh" (70), but it nonetheless shows Faustus' willingness to give into the devils, as well as his weak reaction to their insistent influence. He then echoes Mephistopheles' own words when he tells the devils to torment the Old Man (80), further demonstrating the powerful influence of the devils over his will, and the instability of his conviction which allows him to flip sides on an apparent whim.
} 
Faustus seems to inherently recognize that the stakes are much higher than he originally

theorized. At the start of Act Two, he laments:

Now, Faustus, must thou needs be damned

And canst thou not be saved.

What boots it then to think of God or heaven?

Away with such vain fancies and despair.

Despair in God and trust in Beelzebub.

Now go not backward; no, Faustus, be resolute.

Why waverest thou? O, something soundeth in mine ears:

"Abjure this magic; turn to God again!"

Ay, and Faustus will turn to God again.

To God? He loves thee not.

The god thou servest is thine own appetite,

Wherein is fixed the love of Beelzebub (AII.i.1-12).

As soon as the idea of submitting himself to the service of the devil becomes a reality, ${ }^{99}$ Faustus'

prior confidence in the physical world dissolves into concern for and distress in the

metaphysical. While never unsure of his ability to master logic, law and medicine, for the first

time, Faustus demonstrates worry for a part of himself he cannot manipulate for his own

purposes: his soul. He also begins to express a doubt that has thereunto been absent from his

character, as he openly wavers between thoughts of God and the devil, between salvation and

damnation, further demonstrating the uncertainty that follows from his primary confluence with

Mephistopheles.

Barbara Traister also observes the significance of the change in Faustus' language; where at the beginning, his "power lies in his words" (106) and he seems "intoxicated by his own rhetoric" (94), as the plot continues, "the general sense of loss in the play is the ....failure of action to live up to words" (96). His intoxicated rhetoric is manifest in the active verbiage he

\footnotetext{
${ }^{99}$ In AI.iii, Faustus first conjures Mephistopheles and sends him back to Lucifer to arrange a contract, whereby Faustus "surrenders up to him his soul, / So he will spare him four-and-twenty years, / Letting him live in all voluptuousness, / Having thee [Mephistopheles] ever to attend on me" (90-93). However, the actual signing of the contract does not occur until after the monologue quoted above; therefore, I argue, that it is not the contract that initiates Faustus' internal conflict over the fate of his soul, but the introduction of the devils.
} 
uses to express his self-assurance in his own abilities, but as that confidence disintegrates into psychological instability, his language becomes less tied to his own capability to act. This is specifically evident in the discrepancy between Faustus' linguistic commands and Mephistopheles' actions, which speaks to a popular issue of debate at the time Marlowe was writing. In the early 1590s, George Gifford (Dialogue Biv) and William Perkins (134-35) attacked the widespread belief that magicians could control devils through speech, particularly when it came to conjuration; they argued that Lucifer used the illusive link between the two to lure men towards damnation. Indeed, Mephistopheles himself supports this claim when he tells Faustus that he appears not at hearing the summons, but "came hither of my own accord" (AI.i.44). Severing the connection between what Faustus says and his capability to exert action creates an empty rhetoric which is no longer performative, or even proof of his ability to accomplish by his own means, but an airy show of authority by a man who has sacrificed any power he might have had before. ${ }^{100}$

Thus, I agree with Traister that the "failure of action to live up to words" indeed signifies the major loss in the play, though I believe that the loss itself is not the power of Faustus' linguistic command, but his certainty of self, for which his use of language is key in order to express his capability for mastery of earthly knowledge. The decreasing effect of that language coincides with Faustus' own dissolving sense of self - once rooted in the physical, material, and empirical, now destabilized by the uncertainty of the metaphysical, the uncontrollable. While he continues to outwardly assert a linguistic boldness that resembles the confident Faustus we see at

\footnotetext{
100 This occurs again when, after Faustus sends Mephistopheles away to present his offer to Lucifer, he claims, "now that I have obtained what I desire" (AI.iii.112). However, as of yet, Faustus has obtained nothing, as the contract is not actually signed until the start of the next act, and so all of the feats he imagines accomplishing through the help of Mephistopheles ("By him I'll be the great emperor of the world" (104-05)) are still only fantasies. This is yet another example where, after he begins engaging with the devils and the possibilities of magical power, Faustus' words become void of literal meaning and/or capability for action.
} 
the start of the play, the significant difference is that he displays such boldness only around Mephistopheles to maintain the illusion that he possesses the same self-security which he has always had. The irony, of course, is that this active language, once reflective of Faustus' certainty in his own capability to acquire knowledge, becomes an overcompensation for the decreased self-confidence he experiences under the contract:

Have not I made blind Homer sing to me Of Alexander's love and Oenone's death? And hath not he that built the walls of Thebes With ravishing sound of his melodious harp Made music with my Mephistopheles?

Why should I die then or basely despair? (AII.iii.26-31)

The form and content of this speech closely resembles the first monologue of the play where the audience is introduced to Faustus touting his various academic accomplishments. The key difference, however, is that, unlike in the first catalogue, Faustus cannot claim credit for any of the feats he lists here, as it is Mephistopheles who has the power to manifest the dead Homer. Faustus only communicates his desires to Mephistopheles, who is the one with the ability to act on those words - something Faustus himself proved capable of only prior to his encounter with the devils. This is where the change in his language becomes significant. Before, Faustus could ask himself "hast thou not attained" mastery over multiple spheres of worldly knowledge, convinced that he himself had achieved these things. But after his first encounter with Mephistopheles, he begins to defer to his devil companion to perform the great feats that he believed himself once capable of doing alone. After Mephistopheles first appears, Faustus begins to imagine his various impending triumphs, but he admits, "had I as many souls as there be stars / I'd give them all for Mephistopheles. / By him I'll be a great emperor" (AI.iii.102-04, emphasis mine). The idea that Faustus can only ever achieve anything magical with Mephistopheles' power echoes again in the large quotation above, where the builder of Thebes made music with 
Mephistopheles - the preposition connotes not only partnership, but facilitation (as synonymous with the above "by"), as though Mephistopheles was involved in the music making both as a musician and as the conductor of the whole affair. Furthermore, at the end of Act One, Scene Three, Faustus again says, "I'll live in speculation of this art / Till Mephistopheles return again" (113-14). The fact is that Faustus can only speculate on the art because until Mephistopheles returns, he has no real power to perform it. Thus, the great scholar contents himself to wait on the pleasure of a devil who is supposed to be serving him. Why? Because his belief in his own capability to act and accomplish decreases with the entrance of the devils, whose command over the occult and otherworldly power causes Faustus to reduce his belief in his own ability, and to become reliant on Mephistopheles to be the master.

Faustus' deference to Mephistopheles is further apparent in regards to the kind of exploits he desires to undertake through the power of the occult. When speaking to Valdes and Cornelius about conjuring spirits, he exclaims:

I'll have them fly to India for gold, Ransack the ocean for orient pearl, And search all corners of the new-found world For pleasant fruits, and princely delicates. I'll have them read me strange philosophy, And tell the secrets of all foreign Kings. I'll have them wall all Germany with brass, And make swift Rhine, circle faire Wittenberg. I'll have them fill the public schools with silk, Wherewith the students shall be bravely clad. I'll levy soldiers with the coin they bring, And chase the Prince of Parma from our land, And reign sole king of all the provinces. Yea, stranger engines for the brunt of war Than was the fiery keel at Antwerp's bridge I'll make my servile spirits to invent. (AI.i.82-97)

There are two noteworthy criteria of Faustus' desires. The first relates back to my previous discussion about Faustus' tie to the worldly. Here again, his desires centre on physical, tangible, 
material things that he can conceive of in his mind-Indian gold, orient pearl, fruits, metals, clothing and armies. Faustus does not seek treasures beyond earth, but the inner thoughts of foreign, yet earthly, kings. The second is in regards to the nature of the things he hopes to accomplish, most of which, practically speaking, Faustus does not require magic to do. Though not as instantaneously as Mephistopheles might, Faustus himself could travel to India for gold, the orient for pearls, and other exotic locales for foreign pleasures. In fact, he could experience these treasures without leaving Germany at all, given the state of new-world discovery at the time. ${ }^{101}$ And why would a master scholar need occult spirits to read him strange philosophy? Could he not set himself the task of learning the language of such works in order to read it himself? His other requests focus on politics and the military: to learn the secrets of foreign kings, and levy an army to win back control of his home territory from a foreign prince. Could not Faustus, an educated man of renown because of his numerous academic accomplishments, enlist himself as a political advisor to powerful people, wherein he could one day be in a position to engage with foreign leaders, and even have a say in the country’s military movements? Hattaway, too, observes that Faustus' desires “could pass for natural... and non-blameworthy activities" (62), had he engaged more acceptable means of attaining them. But Faustus never considers trying his own hand at any of these, nor does he look upon them as a new challenge he might undertake in the wake of being so evidently bored by the other disciplines he has exhausted. Instead, he relies on Mephistopheles to achieve them, sacrificing the very thing that makes Faustus who he is-his capability for mastery. Lemon seems to agree, as she writes that

\footnotetext{
${ }^{101}$ There is an entire genre of scholarship on European travel and travel writing during the early modern period, which was touted as an age of travel and discovery. See, for example, Sanjay Subrahmanyam's "Connected Histories: Notes Towards a Reconfiguration of Early Modern Eurasia”, Modern Asian Studies, vol. 31 no. 1, 1997, pp. 735-62, as well as much of the work written by Joan-Pau Rubies, including Travellers and cosmographers: studies in the history of early modern travel and ethnology, Ashgate Publishing Ltd, 2007 and "Travel Writing as a Genre: Facts, Fictions, and the Invention of a Scientific Discourse in Early Modern Europe", Journeys: The International Journal of Travel and Travel Writing, vol. 19, 2000, pp. 5-35.
} 
Faustus seeks his power "through the utter surrender of himself, releasing his own mind into [the] metaphysical" (879). The confidence he once possessed in his own ability has dissolved into his dependence on Mephistopheles to achieve great things for him.

The tragic irony of Marlowe's play is that Faustus attempts to combat his religious despair by using magic to affirm his capability for greatness, but magic has the opposite effect. Instead, his engagement with the occult initiates intellectual and religious despair, which operate in positive correlation, as the more he yields the command of mastery to Mephistophelesbecause of his increasing lack of confidence in his own ability to acquire knowledge - the more concerned he becomes with the fate of his soul ${ }^{102}$. His despair at the likelihood of being damned causes him to turn away from God in favour of serving his own appetite. This choice starkly counters the tale of Jane Oxly, whose despair does not become an excuse for self-indulgence, but rather a vehicle for mercy and compassion for those she has wronged. Unlike Faustus, Miss Oxly does not seek to avoid her despair through distraction, but rather turns a period of internal torture into an opportunity to demonstrate Christian values. In so doing, she simultaneously challenges Protestant ideas of despair by refusing to have it consume her beyond all thoughts of God, and is nonetheless folded back into the moral schema which frames the author's telling of the tale by feeling unable to escape her damned fate despite her shows of moral character.

\section{The Divine and the Demonic}

It is unfortunate that in order to make the case of Jane Oxly suit his moral purpose, the anonymous author of the pamphlet overlooks her intriguing and complex reaction to her own

\footnotetext{
${ }^{102}$ When I suggest that the two despairs operate in positive correlation, I am referring to the fact that they occur alongside one another, and that they are most strongly related because of the ways they contribute to Faustus' crisis of identity - both his spiritual self, in terms of the afterlife of his soul, and his individual, philosophical selfhood, which he roots in his ability to acquire earthly knowledge. Admittedly, I am unsure whether the two despairs are related beyond this shared effect on Faustus, though I believe their parallel progression contributes to a fascinating psychological study of the protagonist.
} 
despair, which insists on an individual's power to determine how they confront their fate, even if fate itself is indeed beyond a person's control. One might go so far as to suggest that Miss Oxly refuses to submit to contemporary expectations of one in her circumstance, and in doing so, she exerts some control in how she chooses to confront the despair from which she suffers. Faustus, on the contrary, lacks similar authority. By turning away from God, Faustus does not become his own master; rather, he replaces one master for another, as he reiterates, "when Mephistopheles shall stand by me, What god can hurt thee, Faustus? Thou art safe. / Cast no more doubts." (2426) By submitting himself to Mephistopheles' power and protection, Faustus enlists himself in the service of another spiritual figure, the presence of which only increases his awareness of the damnation he seeks to evade contemplating. Constance Brown Kuriyama argues similarly, writing that "the fundamental irony of the play is that Faustus, in trying to escape one set of restraints, has only implicated himself in another set that derives from and parodies the original" (125). Furthermore, while Faustus desires to substitute thoughts of the uncontrollable, unknowable afterlife with a world he can understand, his constant deference to Mephistopheles and the increasing discrepancy between his words and his ability to perform real action demonstrates that as Faustus becomes more involved with the devils, the less certain he becomes about himself, both his capability on earth and the fate of his immortal soul. ${ }^{103} \mathrm{I}$ argue that this developing uncertainty stems from the presence of Mephistopheles, who Faustus cannot control nor can he predict or fully understand his thoughts or actions. This inability to exert control, to master the devil because of his uncertain nature leads Faustus to a diminishing belief in his ability to achieve in other realms as well.

\footnotetext{
${ }^{103}$ Andrew Sofer argues that "stretched on the rack of uncertainty, Faustus seems determined to settle the question once and for all" (20), and just as he hopes the spirits will "resolve me of all my ambiguities" (I.i.80), the irony is that the looming presence of the devils only exacerbates his uncertainty in himself, and about his ultimate fate.
} 
Moreover, as he further entangles himself in the devils' web, thoughts of damnation continue to plague him, as alone again a few scenes later, he laments:

My heart's so hardened I cannot repent.

Scarce can I name salvation, faith, or heaven, But fearful echoes thunder in mine ears

Faustus, thou art damned. Then swords and knives, Poison, guns, halters, and envenomed steel

Are laid before me to dispatch my self, And long ere this I should have slain my self, Had not sweet pleasure conquered deep despair. (AII.iii.18-25)

Here Faustus seems to contradict himself in another display of the disconnection between his words and the reality of his internal conflict. He begins by admitting his fear of God because of what he believes to be his own damned fate, and yet he concludes by claiming that his despair has been conquered by the various pleasures his devilish bond has afforded him. However, the fact that he continues to contemplate the fate of his soul is proof of the contrary—that despite his bond, he cannot escape his fear of the spiritual fate awaiting him. Moreover, the fact that he is given the tools to end his life, and so end such internal struggle for good, yet cannot bring himself to do so further speaks to his decreasing ability to act, especially as he claims that he avoids such desperate action on account of his supposedly "conquered" despair which, as we have seen, is not quite so. Nor does it abate as the play continues, as even in Act Four Faustus admits "Despair dost drive distrust into my thoughts" (AIV.i.134). But the question of who Faustus distrusts is now ambiguous. While before he dismisses God in favour of the devils, now he follows his claims of distrust with a recollection of Christ's mercy ${ }^{104}$, implying that he is not as mentally committed to the devils as he appeared at first.

\footnotetext{
${ }^{104} \mathrm{He}$ recalls, "Tush, Christ did all the thief upon the cross" (IV.i.136) as a way to comfort himself—-that even nearing his final hour, he might yet be saved.
} 
It is telling that his despair is a result of his fear of the God who would see him damned — whether as punishment for his sins or simply being born reprobate. But, despite his earlier declaration that he has nothing to fear from Mephistopheles, it soon becomes obvious to him that the devils engage in the same kind of fearful control that caused him to turn from God. In another of his debates about repentance, the evil angel assures Faustus that "if thou repent, devils shall tear thee in pieces" (77), and as soon as Faustus cries out to Christ to "save my distressed soul" (80), Lucifer appears as a menacing reminder of the commitment Faustus has made, and the impossibility of breaking it without enduring painful consequences. Faustus then finds himself trapped in his contract with the devils, and his increasing reliance on Mephistopheles to aid him in his exploits_-for example, it is Mephistopheles who must "charm" Faustus invisible so he can prank the Pope and his cardinals (AIII.i.55), and he later tells the Emperor he can perform only "by art and the power of my spirit [Mephistopheles]" (AIV.i.42)— coincides with his gradual descent into total, helpless submission. Just as he does not believe he can effect change to the fate of his soul, so he begins also to doubt his ability to accomplish anything alone, as he used to. Furthermore, the more entrenched Faustus becomes in his religious despair, both in the possibility of his damnation and in his servitude to the devils, the less masterful his ambitions are (coinciding with the rise of his intellectual despair). The great feats he desires at the start of the play devolve into parlour tricks and childish pranks: petty revenge against a knight who insults him, infantile games of deceit with a simple and unsuspecting horsecourser. ${ }^{105}$ No longer does he seek to conquer and colonize, to raise armies and advise kings, but these magnificent desires are replaced by a desperate desire to impress, to show that he is, in fact, still capable of any kind of achievement. He brings forth the image of Alexander the Great in

\footnotetext{
${ }^{105}$ See IV.i.73-93, and 105-179 for these episodes.
} 
order to "sufficiently content" (AIV.i.54) the Emperor, and to "delight [him] with some mirth" (86-87). Faustus inadvertently takes on another submissive role, and so his initial dreams of mastery and control are subdued beneath the requests of the nearest political leader. This occurs again with the Duke, who himself notes Faustus' "courteous intent to pleasure me" (AIV.ii.8). Faustus's thoughts of mastery decline altogether disappear by the end of the play, which, I argue, is a result of the coinciding spiritual uncertainty he battles as "hell strives with grace for conquest in [his] breast" (AV.i.64). However, his experience with fear of both heaven and hell creates a parallel, rather than an opposition between the two, so that the uncertainty he feels is not about salvation or damnation, but about the Protestant afterlife as a whole. Both God and the devils engender despair and distrust which Faustus cannot shake, as the only element he might have used to combat them - his own capability for mastery, his certainty in himself as an accomplished academic of the physical world - has been surrendered in his futile attempts to evade confronting his eternal fate.

By making God and the devils two sides of the same coin, Marlowe effectively reconfigures the nature of Faustus' struggle. It is not, as many scholars have argued, ${ }^{106}$ necessarily a battle between the forces of good and evil, but one between, as Cox notes, "religious belief or unbelief, where the stakes are...between worldly success and eternal damnation" (Devil and the Sacred 123). Until the final monologue, the play positively correlates Faustus' religious despair for his soul and the intellectual despair of his decreasing sense of mastery. However, the two trajectories diverge at the end because Faustus comes to view God and the devils in the same light. The contrary nature of ideas surrounding Protestant despair lay

\footnotetext{
${ }^{106}$ See, for example, Warren D. Smith's article "The Nature of Evil in Doctor Faustus", The Modern Language Review, vol.60 no.2, 1965, pp. 171-175, and Emil Roy's "Faustus' Dream of Punishment", American Imago, vol. 34 no.2, 1977, pp. 158-170.
} 
in the expectation that people would act is if they were saved by God, despite accepting the fact that they were likely damned. But, if God and Lucifer come to mean similar things, then arguably salvation and damnation, too, become similarly signified. Despair, then, is not a case of lacking grace, but of lacking hope altogether. As the play demonstrates, Faustus finds only despair, fear and self-doubt in his psychological and physical engagement with the spiritualdivine or otherwise. His psychological trajectory suggests that despair is an inevitable result from the uncertainty inherent in Protestant ideas about one's spiritual fate, and rather than being a conduit for repentance and salvation, the experience of despair itself is harrowing and damning, and leads the "wretched" into acts of "desperation", as Article Seventeen itself suggests. Faustus responds to this bleak position by redirecting his thoughts towards the earthly, material worldthe only place where he ever had a coherent sense of self, dominated by his belief in his own capability for academic and intellectual mastery. He repudiates the idea of God and heaven in his final soliloquy, who he still views with fear and mistrust (Kuriyama 100) even as he faces a damnable alternative: "And see, where God / Stretcheth out his arm and bends his ireful brows! / ... / ...hide me from the heavy wrath of God!" (AV.ii.77-81) And even as he claims he will "leap up to my God" (71), his hopefulness is only temporary because thoughts of God are equated with thoughts of the devil, and so of torment and damnation. Faustus blurs the lines between heaven and hell, between God and Lucifer, when he says, "rend not my heart for naming of my Christ! / Yet will I call on him. O spare me, Lucifer!" (76-77) Faustus' paralleling of Christ and the devil reflects his consideration of them as part of the same problem — as promulgators of a despair which inhibits a person's ability to find and maintain self-assurance.

It is also telling that Faustus attempts to understand the spiritual in terms of tangible concepts that he can mentally digest. He references Christ's blood specifically (74), noting that, 
“one drop would save my soul" (75), as he can only conceive of salvation in earthly terms, while the otherwise abstract, transcendent nature of being saved escapes him, and causes the wavering uncertainty and doubt we see so often in his self-debates. And when he does eventually think of his eternal soul as his final hour comes to a close, he cries out for "mountains and hills, come, come and fall on me, / ... / ...Then will I run headlong into the earth" $(80,82)$. When at the start of the play, Faustus summons Mephistopheles and the devils in a similar way_ "Come Mephistoheles / Veni, veni, Mephistophile!" (II.i.27-28)—by the end, he rejects such spiritual summons in favour of the earthly,_“Come not, Lucifer!” (AV.ii.115, emphasis mine)—wishing the earth would swallow him up so that he might return fully to it. While it can be argued that Faustus is asking for a physical burial without spiritual consequences, such a suggestion nonetheless corroborates my argument that he desires a return wholly to the material earth, while forsaking any form of afterlife. His desire to be dissolved back into nature demonstrates his repudiation of the spiritual afterlife, the thoughts of which have inflated his religious despair and, consequently, shattered the surety and stability of his once capable mind. And though he begins by wanting to master the natural elements, his concluding speech signals a desire to be mastered by them, in a final surrender to the physical world which created the sense of self he foolishly took for granted. Lemon agrees that in the end, Faustus' desires are oriented towards pursuing a path for life — not salvation, but earthly life (866). Cleanth Brooks similarly observes that in this final soliloquy, Faustus' concern 'is with holding back the clock, not in changing his relation to God" (qtd. in Marlowe 290). Indeed, he asks that the final hour might be "a year, a month, a week, a natural day", and yet "time runs and the clock will strike" (V.ii.68, 70). As in the case with the image of Christ's blood as material emblem of salvation, the clock becomes a physical 
signifier for Faustus to try and rationalize the idea of time - not only the time he has left, but the concept of eternity, which looms before him terrifying and completely incomprehensible.

In the end, Faustus finds comfort not in God, or even in Lucifer, but in the natural world - the stuff of intellectual study which defines him. With his final pleas to the hills and the mountains, Faustus' intellectual despair takes precedence over Protestant despair, which, rather than prove an effective vehicle towards repentance and salvation, is revealed as an ideological crisis of identity stemming from a spiritual uncertainty that not everyone can successfully navigate, especially not in a world rooted in the desire to know. As a counter to this complex and compromising concept, I believe that Marlowe gestures towards, what Karol Cooper calls "a different kind of salvation, one that depends on the loss of Christian identity, rather than its maintenance" (5). Unlike Jane Oxly, who seems to forgo all thoughts of salvation despite demonstrating the mercy and compassion of one who is saved, Faustus does, for a moment, see his salvation. However, that grace is not given by God, who, in Marlowe's play, comes to elicit the same damnable despair as his Satanic foils. Rather, Faustus hopes for salvation in the natural world, the same empirical matter from which he built his sense of self. For the world of earthly knowledge represents the only place Faustus feels secure, certain, free of the debilitating uncertainty religious despair engenders. While much of the play parallels Faustus' spiritual and intellectual struggles, in the end, it becomes evident that there is only one realm in which Faustus might have saved himself. By exploring what Jonathan Dollimore notes is, the tension between moral structures and the Renaissance focus on knowledge, where "the search for knowledge becomes a search for security among the uncertainty promulgated by cherished orthodoxies" (323, 326), Doctor Faustus highlights the inherently divisory nature of doctrinal despair which 
risks shattering the stability of his sense of self by catapulting him outside the world he can

master, the world he can know, and into an obsessive contemplation of spiritual unknowing.

\subsection{The Penitent and the She-Devil}

Near the end of 1683 in Spreyton Village, Devon, a spectrum resembling the wife of a

local deceased Gentleman appeared to a young man in the fields with his horse. ${ }^{107}$ The spectrum,

or daemon ${ }^{108}$ - the anonymous author of the pamphlet refers to it as both - "threw the young man

off his Horse...cast him with such Violence to the ground... his body being Cast with incredible

Force". She continued to physically torture the young man in various ways in several encounters

afterwards, once "getting his head stuck in such ways that cause bleeding and bruising to get it

out; straining pre-existent wounds with such force that [it] almost stopped his breath and killed

him". She also tore the very clothes the young man was wearing, but only if the clothes were his

own - if they belonged to another, she left them be. The young man recalled praying often to

God "not to suffer the Devil to destroy him", and this would always break whatever enchantment

the spectrum had him under (once, for example, he was found in a bog "in a kind of Trance or

Exatick Fit").

107 This tale was taken from an anonymous pamphlet entitled $A$ Narrative of the demon of Spraiton in a letter from a person of quality in the county of Devon to a gentleman in London: with a relation of an apparition or spectrum of an ancient gentleman of Devon, who often appeared to his sons servant, with the

strange actions and discourses happening between them at divers times : as likewise the daemon of an ancient woman, wife of the gentleman aforesaid, with unparalell'd varieties of strange exploits performed by her

:attested under the hands of the said person of quality, and likewise a reverend divine of the said county:

with reflections on drollery and atheism, and a word those who deny the existence of spirits, 1683, Wing / N180, EEBO. 23 Aug 2018.

${ }^{108}$ Beaumont writes that what the Latins called Genius - “the secret Power of Celestial Bodies, by which we are impell'd to do all things...supporting or suggesting good or bad Thoughts in our Minds"_-Greeks called Daemon, "prudent, knowing, skillful... and foreseeing things, they giving Answers to those that consulted them" (2), noting that Greek philosopher Apuleius wrote that the mind of man itself, even while still in the body, could be referred to as a daemon (3). As the world became increasingly Christianized, the term evolved accordingly, as Beaumont notes that there are both good and evil daemons, and while good ones can warn us of danger, evil daemons set out to hurt mankind. Furthermore, "the Evil Daemon, by bad works, endeavours to make us conformable and united to him...when a Daemon flows into an Humane Soul, he sprinkles in it Seeds of his own Notions" (7). 
Like the case of the ghost of William Barwick's wife, which I discussed in the previous chapter, the author of this pamphlet relays the young man's encounter with the female daemon in the service of combatting atheistic tracts—-specifically Thomas Hobbes' Leviathan — which "indulg[e] themselves in whole Bestial Sensualities, [and] dare not admit the Consideration of an after reckoning". The author attempts to use the tale presented here to prove the existence of spirits, and so the existence of a higher, spiritual realm, which such works would deny. $\mathrm{He}$ ridicules the idea that our "Heaven-born Souls [a]re capable of no higher enjoyments than the sickly pleasures of a sensual Life", claiming those who refute the possibility of an afterlife where immortal souls venture after death "overwhelm their Pampered and deluded selves in an Eternal Gulph of Inextricable Misery”. The author rails against playwrights like Marlowe whose Doctor Faustus, as I argued in the previous section, "employs his Faculties and Reason, to fight against" — or deny altogether- “the God that gave them to him". Instead, the Spreyton pamphlet aims to use the story of the tormenting female daemon to remind people that they "have Souls to provide for", and so should guard them against the very real satanical forces that seek to prevent their soul's eventual return to Heaven.

But there is a significant element of this tale that the author does not address - the fact that the spectrum is referred to several times specifically as a female daemon. In his work, $A n$ Historical, Physiological and Theological Treatise of Spirits, Apparitions, Witchcraft and other Magical Practices (1705), where he traces the evolution of the word "daemon" from its Greek to Christian connotations, John Beaumont always refers to evil daemons - aligned with the Christian devil—using male pronouns $(7,256)$. King James I, in his Daemonologie, also unilaterally refers to the Devil and his associates as males (52) — and this seems to be the overall 
tendency in early modern treatises about demons and the demonic. ${ }^{109}$ Thus, it is odd that the anonymous author would put such emphasis on this daemon being a female terrorizing a male, especially as James I states in his treatise that women were more likely to be dogged by the devil because "woman is frailer than man is, so is it easier to be entrapped in the grosse groves of the Devill, as was ever well proved to be true by the Serpents deceiving of Eve at the beginning, which makes him the homelier of that sexe" (44). But in the 1683 pamphlet, there is a specifically female demon plaguing a young man, and the author makes it quite evident that she is targeting the man alone, and not just anyone who crosses her path. The author mentions that the young man was often accompanied by the Gentlewoman's maidservant—-the same Gentlewoman in whose likeness the daemon appears - but she never attacks the young woman, only her male companion. It is further curious that the daemon embodies the kinds of characteristics which made early moderns like James I assume that women were inferior to men, including emotional aggression and violent impulsivity. However, the pamphlet never addresses the anomaly of the female daemon, nor does it consider the potential implications of the genderspecific encounter. Such complex intricacies are dismissed in favour of reiterating the author's primary purpose, which is to encourage people to maintain faith in the Christian afterlife, and, consequently, to prepare their souls to meet the Creator.

\section{A Problematic Penitent}

While the 1683 pamphlet does not explore the atypical and complicated gender relations between the female daemon and her male victim, Thomas Middleton's A Mad World, My Masters undertakes similar gender dynamics, free from the theological constraints of the pamphlet's dominant moral framework. The character of Penitent Brothel is at the centre of this

\footnotetext{
${ }^{109}$ See also Anthony Anderson's The Shield of our safetie, George Sinclair's Satan's Invisible World Discovered, Richard Baxter's A Certainty in the World of Spirits etc.
} 
exploration in Middleton's play: a self-righteous preacher who is stereotypically hypocritical in his criticisms of others' impiety while himself violating the moral boundaries of his order.

Robert L. Root Jr. observes that the dual nature of Penitent's name itself reflects the opposing halves of his character, "the moralistic tendency warring with the hedonistic urge" (84).

However, from the beginning of the play, Penitent Brothel is aware of his own moral shortcomings and his hypocrisy as a lusty clergyman. In the middle of his criticisms of Mister Follywit's deception of others, Penitent Brothel stop to lament:

But why in others do I check wild passions, And retain deadly follies in myself?

I tax his youth of common receiv'd riot, Time's comic flashes, and the fruits of blood; And in myself soothe up adulterous motion, And such an appetite that I know damns me, Yet willingly I embrace it (I.i.90-95).

He openly questions his right to give moral guidance to others, while he himself not only engages in, but fully embraces, immorality. Furthermore, he seems to admit to a fault in his rational faculty, which works externally to check the passions of others, but cannot stand up to the powerful force of his own internal appetite. And why does his reason lack enough influence over the appetite to tame it? Because Penitent himself wills it otherwise. Charles Hallett similarly notes that the object of Penitent's desire, Mistress Harebrain, makes his will a slave to his appetite (78), to the extent that it overrides his better reason; Penitent indicates that he knows the pursuit of his desire is damning, and yet his willingness to have her supersedes any rational argument against it. In her discussion on the role of the will in Renaissance psychology, Paz Eulalia Lacuna Saplala notes that even as contemporary tracts on the early modern mind emphasized the freedom of the will to reject or be guided by reason, "it is easier for the will to adhere to the sensual appetite, to the "passions and perturbations of the mind" [Burton] than to 
reason because the good from reason is not always apparent or as easily attainable as the apparent good from the senses" (22). Here it seems the rational good is a moral Good, whereas the sensual good constitutes a personal determination of what most benefits the individual in that moment. Thus, by forsaking the former in favour of the latter, Saplala argues that Middleton's character psychology of Penitent Brothel suggests that people are inherently weakpsychological weakness in the Renaissance being characterized by “the incapacity of man's reason to subdue and govern the unruly passions" (39). However, this weakness manifests in Penitent, ironically, as an irrational outrage towards the infallibilities of women, the inherent moral fragility of whom Penitent blames for his own immoral action.

For all the self-awareness Penitent Brothel displays in the first act of the play, his acknowledgement of his own flaws seems to diminish the more involved he becomes with his pursuit of Mistress Harebrain. It is as though the more he succumbs to his passions, the less rational and objective his perception, both about himself and the others around him, becomes. This is evident in the middle of Act Three, when he engages in the same kind of criticism of Sir Bounteous that he does of Mister Follywit at the start of the play. In several asides, he mocks Bounteous for being unwittingly "purg'd" (III.ii.17) of money by the courtesan, calls him a "weak knight" (34), and judges that he is "himself, gone" (84), as though mentally aloof. He then goes on to tout his own abilities for recognizing the true characters of others, saying "we physicians see the most sights of any men living...we look downward into th'body, and indeed we have power upward and downward" (115-18). The irony is that Penitent is only dressed up as a physician, so any power to look inside someone and see the truth of their person is not one he himself can assume. However, he demonstrates his self-righteous hypocrisy by exacting this judgement nonetheless, and whereas he previously stopped himself to recognize his own 
misgivings - thereby implying an acknowledgement of the tenuous position from which he judges others-in this scene, there is no such reflective introspection. Rather, he concludes the scene by going off with Mistress Harebrain to commence their affair, thus more fully indulging himself in the immoralities which the power of his passions prevent him from admitting.

After he has attained the object of his desire, Penitent's self-awareness is problematically impaired, and this is most apparent in the monologue which opens Act Four. It might be argued that he displays the kind of self-scorn that he does in Act One, and indeed, he does seem to voice regret for his immoral indulgence:

Ha! Read that piece again, "Adultery Draws the divorce "twixt heaven and the soul." Accursed man, that stand'st divorc'd from heaven, Thou wretched unthrift, that hast play'd away Thy eternal portion at a minute's game To please the flesh, hast blotted out thy name, Where were thy nobler meditations busied That they durst trust this body with itself, The natural drunkard that outdoes us all And makes our shame apparent in our fall? (IV.i.1-10)

However, on closer analysis, Penitent's use of pronouns suggests that he is attempting to evade individual responsibility for his immoral actions by pointing to the overall depravity of the human race. While "accursed man" and his use of "thou" and "thy" might indicate Penitent is scolding himself for the affair, as the monologue continues, his weakness towards physical desire becomes a universal vice: the "natural drunkard that outdoes us all / And makes our shame apparent in our fall". His explicit use of the third person plural near the end suggests that the "man" Penitent scorns at the start is not himself in the singular, but humans as a depraved race. This implies that even where Penitent might recognize the error of his adultery, he nonetheless resists implicating himself specifically, but rather incorporates his own error into a larger scheme 
of human flaw. This prevents him from admitting his individual immorality, and lessens the weight of that fault by making it typical of humanity.

In the second half of the monologue, Penitent's evasion of individual accountability for the affair becomes more apparent, as he moves from implicating all people, a population in which he includes himself, to pointing to a specific group of the population in which he has no part:

The end of man, and glory of that end

As endless as the giver,

To dote on weakness, slime, corruption, woman!

What is she, took asunder from her clothes?

Being ready, she consists of hundred piece

Much like your German clock, and near allied:

Both are so nice they cannot go for pride,

Besides a greater fault, but too well known,

They'll strike to ten when they should stop at one.

$\cdots$

Sin's hate is the best gift that sin bestows;

I'll ne'er embrace her more; never, bear witness, never. (IV.i.16-29)

Where, just lines prior, the body is the natural drunkard to which all people are vulnerable, here the weakness of will and the pull of desire become associated with women specifically. In one line, he parallels woman with weakness, slime and corruption, which implies that men are exempt from such vices unless they dote on them by engaging with the inferior sex. Furthermore, he degrades the worth of women by reducing it to the physical alone, and even at that they do not stand out exceptionally; the condescending tone of "what is she, took asunder from her clothes" indicates that unless fulfilling physical purpose, and even then, woman offers little that should tempt a man away from his higher calling. Penitent goes on to spit stereotypes of women as variant, excessive, and dangerously unpredictable. Editor Standish Henning notes that the reference to the German clock is "an allusion to the cumbersome and complicated machinery of our first clocks, which came from Germany" (IV.i n.21). In addition to the dehumanizing effect 
comparing his mistress to a mechanical, inanimate object has, Penitent's reference to the complexity of the clock is not flattering in this context, as the "hundred pieces" of which it consists creates an incomprehensibility that counters the plain simplicity of ideal early modern women. Confusion caused by the multiplicity of their parts, and of their faces, becomes a veil of deception that women can then use to beguile unsuspecting men. Furthermore, the clock's many parts echoes its excessive tolling; women, likewise take things further than they should, whether the pursuit of their desires, their immorality, their indulgence in human weakness etc. The overstriking clock signifies the excess of women who seek to pull good, moderate men into their realm of vice, and so their weakness becomes a physical and a moral contagion. Thus, Penitent vows to separate himself from his former temptation-Mistress Harebrain - when he swears never to embrace her again. He also associates her, the woman and not necessarily the act of adultery in which he too engages, with sin itself when he states "sin's hate is the best gift that $\sin$ bestows". Evidently, here his hatred is directed at the object of his desire, and not the sinful actthe acknowledgement of which would warrant a recognition of his own role in the affair. Instead, he blames Mistress Harebrain for any immorality, and in so doing, Penitent demonstrates a problematic digression in his self-awareness, as he refuses to admit his personal responsibility in succumbing his will to his passions - a vice which he attributes to women alone.

Penitent's depiction of the weakness of women reflects the author's portrayal of the female daemon in the Spreyton pamphlet. Just as Penitent associates women with sin and hell"If I meet then, hell and my soul be mix'd" (IV.i.26)—so the spirit in the pamphlet is a literal manifestation of a she-devil, the image of a woman spawned of hellish forces, and she acts accordingly. Indeed, if Penitent asks what a woman is without her clothes, the daemon answers: a torturing menace to men. The physical assault that the daemon commits upon the young man 
parallels the way Penitent depicts women using their physicality to assault male reason and morality. The difference between the two is that while in the play women's weapon is desire, in the pamphlet it is the outpouring of emotion which manifests in violence and aggression. However, all three characteristics coincide with the stereotypical female tendency towards emotional excess and immorality_presumed afflictions, inherent in the weaker sex, which justified men subduing women under the laws of the patriarchy.

\section{The Lady is a Devil}

But, in the episode that directly follows Penitent's self-righteous monologue, Middleton uses the succubus to undermine such stereotypes, and rather than support these views of women as emotionally aggressive and overly sexual — as the female daemon does — the she-devil in $A$ Mad World challenges the validity of such negative female tropes. Some scholars, a few of whom I discuss in a previous section, have denied any critical significance in the succubus scene, or in Penitent's resulting remorse for his actions, because a sudden turn towards solemn morality seems out of step with the otherwise satiric tone of Middleton's city comedy. However, as I mention in that section and will reiterate here, I believe that the scene is meant to appear out of place - the discomfort which the scene instills in the audience, and in the structure of the play itself, is testament to the jarring effect of the scene on Penitent's psyche. The unsettling tone of his interaction with the succubus is heightened by Middleton's depiction of the succubus, who proudly displays its sexuality and actively pursues Penitent in a way that might only be acceptable in more comedic scenes, as presenting them with seriousness might be seen as condoning such behaviour in women. However, the brilliance of Middleton's use of the succubus is that it challenges these problematic stereotypes by fully inhabiting them-and the serious tone of the scene indicates that such lusty stereotypes have become normalized as female tropes, and 
that in itself, is problematic. When Penitent first encounters the succubus, in the image of Mistress Harebrain, he suspects the woman before him really is only a hellish illusion; as such he calls on heaven: "shield me, you ministers of faith and grace!" (IV.i.33) The succubus replies, “are you not asham'd to use / Such words to a woman?” (34-35) implying that reference to divine forces is a kind of affront to women, an offense to their own more demonic nature. This follows in the next line, when "a woman" is immediately succeeded by Penitent's insistence that "th'art a devil" (36), which further aligns the two ideas. The succubus continues to use negative tropes of femininity to taunt and tempt Penitent, encouraging him to 'feel, feel, man' has a devil flesh and bone?" (37) as proof that she is not an illusion but Mistress Harebrain herself. The fact that the succubus pushes physical contact echoes the danger of feminine sensuality which Penitent warns himself against in the monologue prior. Furthermore, her words imply that Penitent would know Mistress Harebrain by touch, which reminds him of their sexual history and attempts to recall his past desire to the immediate present. The succubus indicates as much when she specifically calls on Penitent to "remember" (43).

However, it is not just the affair itself that the succubus wants Penitent to recall. For while she invokes these feminine stereotypes to tempt Penitent to sin, she does so in order to highlight his responsibility in creating her lust, and propagating the sexual desire for which women themselves were often blamed. In response to his rejection of her advances, the succubus asks, "the man has a delight to make me tremble. / Are these the fruits of thy adventurous love? / Was I entic'd for this? to be so soon rejected? / Come, what has chang'd thee so, delight?" (3942). The use of the passive here is significant, as it makes the succubus the object of Penitent's action, just as Mistress Harebrain is the object of his desire: ${ }^{110}$ to make me tremble and thy

\footnotetext{
${ }^{110}$ Gary Kuchar similarly argues that, "as the over-literalized embodiment of male desire, the Succubus situates Penitent in the same position that he...positions Mistress Harebrain... as the object of someone else's desire” (24).
} 
adventurous love puts Penitent in the forefront of lust, as though he was the active agent in pursuing the affair. This is reiterated when she asks, "was I entic'd", indicating that he is the one doing the enticing, tempting her towards immorality—not the other way around, as his previous monologue insists. Furthermore, the fact that he has "chang'd...so" attributes the fickleness and mutability of women, which Penitent points to as blameworthy, to Penitent himself. Here, the succubus begins to complicate their gender roles, as she becomes more aggressively insistent on Penitent's sexual compliance, while mocking his refusal by attempting to emasculate him. In so doing, she both represents the dangerous lusty stereotype of overly sexual, excessive women and the victim of male desire - thereby further signifying the contradictory binary often assigned to women in both society and literature, being the helpless virgin or the hyper-dominant whorewhile nonetheless putting Penitent in a similarly conflicting position as both tempter and coerced object. The succubus is able to manipulate Penitent into both of these roles simultaneously by her rhetoric. When he tells her to leave, she asks:

Have I this meeting wrought with cunning Which when I come, I find thee shunning? Rouse thy amorous interests and twine me; All my interest I resign thee.

Shall we let slip this mutual hour Comes so seldom in her power?

Where's thy lip, thy clip, thy fadom?

Had women such loves, would't not mad'em?

Art a man? or dost abuse one?

A love? and know'st not how to use one?

Come, I'll teach thee (44-54).

The first two lines imply a kind of guilt; that she should have contrived the meeting so carefully indicates that she deserves her sexual gratification - he owes her, which puts the succubus in the controlling, typically masculine role. However, the characterization of "cunning" is further typical of a mischievous woman, as is her open willingness to "resign" herself to him. She also 
indicates that such moments of freedom come "seldom in her power", which highlights the reality of female powerlessness compared to the liberty of men experienced in matters of sex and love. But then she mocks his lack of action, and the imperatives she uses- "rouse" and "twine"- themselves signify her performing the kind of command and control that Penitent seems to be without. It is also she who will "teach" him to be a man, which both further inferiorizes Penitent and masculinizes the succubus, as the devilish temptress is revealed to be increasingly male-like.

I discussed in a previous section that many scholars tend to dismiss the significance of the succubus in Middleton's play as either comic relief or a misplaced attempt at solemnity in a mad world where such genuine intervention is altogether absurd. Others who do grapple with its role in the play often evaluate it through its representative signification. Anthony Covatta, in an attempt to moralize what he sees as an "unsatisfactory intrusion", claims that the act of adultery is hellish, and so is represented by a devil (qtd. in Alwes 102). Charles Hallett alleges that because Penitent is "characterized by a misalignment of the will...the primary function of the Succubus is a psychological one; it symbolizes the last effort of [his] Imagination to overcome his Judgment" (81). I believe that both assessments are problematic because they reinforce the narrative that Penitent fabricates in order to downplay his guilt and his accountability for the affair. Hallett's suggestion implies that until this point, Penitent has demonstrated an abundance of rational judgment. As I have hoped to demonstrate, the skewed perception of his monologue reveals that his judgment when meeting the she-devil is highly flawed, as the more objective attitude he displays at the beginning towards his own shortcomings as well as those of others has become obscurely one-sided. Rather than representing any arbitrary vice, the succubus causes a significant psychological upheaval in Penitent's thinking because it presents as a woman that 
specifically reflects back to Penitent the external blame he spouts in his soliloquy, both by embodying those negative stereotypes, and by unveiling the truth that those criticisms are outward projections of his own internal faults. It is telling that the succubus, in the form of a woman, morphs into a masculine personality, and so when Penitent sees the over-sexualized image of Mistress Harebrain, he is made to distinguish between the true position of the female as pursued object, and the male-dominated undertones of the she-devil temptress. He can only do this because the succubus is itself a she-devil —a literal representation of the stereotype he spouts in the monologue just prior to the encounter-and it is because the succubus exists in and speaks from this already-demonized position that it is so effective in taking the negative tropes it literally, physically embodies and turning them around on Penitent. The result is that even as Penitent stares into the figure of the she-devil, the very embodiment of the lusty, manipulative women that Penitent uses to excuse himself, he is made to see those vices reflected in himselfso the succubus, by literally visualizing the demonization of women, reveals those immoral stereotypes to be mirror images of the men who circulate them.

Finally, a Penitent

The powerful psychological effect of the encounter with the succubus is evident in Penitent's reaction to the episode. He admits to his servant that he has been in "a fit" (76), and demands to know whether Mistress Harebrain has left. Whereas formerly Penitent insists that the succubus is, in fact, a devil and not the real woman, now he refers to the woman herself, which indicates that the self-assurance he demonstrates in his monologue about the sinfulness of women is disintegrating in a blurring of reality and illusion. The power of impersonation is not as evident in the Spreyton pamphlet, where the demon could be seen "habited in the same clothes and dress which the [current] Gentlewoman of the House hath on at the same time". In the 
pamphlet, however, there is never any doubt about who the veritable Gentlewoman is - the witnesses are able to distinguish her from the daemon, as though the power of the devil could not effectively deceive the eyes of moral people. On the contrary, in Middleton's play, the uncertain blending of reality and illusion, in Penitent's confusion - and subsequent misinterpretationabout which appearance of the mistress is an image conjured by the devil and which is the flesh and blood woman, challenges ideas of what is real and what is true, which, as I will discuss later, has significant implications for the play's larger challenge to gender power hierarchies. Penitent's uncertainty about the nature of the woman he encounters is one of the most obvious effects of the shock of the supernatural encounter. Nor is he easily convinced that what he saw was not his real mistress. He asks Jasper several times, “art sure on't?” (82), nonetheless insisting, "why, she struck by thee man" (86) when Jasper reiterates that he saw no one come or go. He questions the Harebrains' servant similarly about when his mistress entered the home, to which the servant replies she had not left in days (IV.iv.8-10). Still, he asks her "what made you at my chamber" (17), indicating that despite the testimonies of two people to the contrary, he cannot ascertain fact from fiction. For the first time in the play, we see an uncertain Penitent Brothel, one without the self-security to scold humankind for vices he himself possesses, but rather one who is forced to confront and reflect on those vices, to risk making himself vulnerable to the possibility of his personal responsibility in negatively affecting the life of another. Contrary to Hallett's suggestion that the succubus represents imagination attempting to override judgement, the encounter with the succubus proves to be one that sets Penitent back on the path towards rational judgement, by causing him to stop and re-evaluate the truth of his own perceptions. 
While some might suggest that his second significant monologue, because it begins in much the same way as the same self-righteous preaching style of the first_- "Be honest; then the devil will ne'er assume thee..." (IV.iv.44)—demonstrates that Penitent's conversion is trivial, if not satiric, I believe that such a reading omits the significance of the second half of the speech where Penitent's psychological shift is most obvious:

Forgive me, Mistress Harebrain, on whose soul The guilt hangs double, My lust and enticement; both I challenge, And therefore of due vengeance it appear'd To none but me, to whom both sins inher'd. What knows the lecher when he clips his whore Whether it be the devil his parts adore? They're both so like that, in our natural sense, I could discern no change nor difference. $\ldots$ There's nothing but our virtue knows a mean; He that kept an open house now keeps a quean. He will keep open still that he commends, And there he keeps a table for his friends; And she consumes more than his sire could hoard, Being more common than his house or board (50-69). ${ }^{111}$

In the first four lines, there is an evident change in Penitent's perception on who deserves blame for the affair. No longer is it the slime and corruption of women, but he himself who is guilty for both their parts in the affair, as it was his lust and desire that drove his pursuit of her, which resulted in her eventual surrender to him. It is further significant that he uses the word "enticement", as it is a direct echo of the succubus' accusation, which demonstrates that her

\footnotetext{
${ }^{111}$ I should acknowledge here that all of the works I discuss in this thesis were not originally meant to be works of literature subject to the kind of analysis I undertake here. They, of course, were plays meant to be performed, and so the several ways in which different actors might perform this monologue can affect the degree to which the audience believes Penitent to be sincere. However, I would argue that while the tone of the actor might influence the credibility of the speech, the language of the play remains the same, and so Penitent's self-implication of his own guilt in whoring Mistress Harebrain is always there. Furthermore, his reaction to the succubus could hardly be played as anything other than pure shock and terror, and that scene is, thus, difficult to ignore or dismiss as trivial when the impact in the moment is so substantial—so, too, I argue does the assumption of his sincerity in his apology naturally follow from the witnessing of such an encounter.
} 
words stay with him, and have an apparent influence on the way he now views the entire affair. ${ }^{112} \mathrm{He}$ now also seems to recover some of the self-awareness that we observed in the first act of the play, as he recognizes that he did "challenge" the role of these faults in himself, and because of that, the succubus appeared to him alone, for it was he alone who needed the kind of psychological enlightenment which the shock of the supernatural encounter was able to produce.

But the larger implications of this psychological change seem to have been overlooked by scholars, who largely dismiss the significance of the succubus in the play. Herbert Jack Heller is one of the few who highlight the importance of Penitent "taking full responsibility for leading Mistress Harebrain astray, and asking her forgiveness...Indeed Penitent is interested in saving Mistress Harebrain from the results of his sin" (90). However, even Heller spends much time discussing how morally aware Penitent seems to be throughout the play, because he recognizes his own sinfulness from the start. I argue that without recognizing the evasion of personal responsibility in Penitent's speech at the start of Act Four, one cannot grasp the full significance of his shift towards forgiveness near the end of the act. Indeed, he is not morally aware because he subsumes his individual vices into a speech about the flaws of mankind as a whole, and it takes the encounter with the succubus to make Penitent realize that he, specifically, has played a role in propagating the unjustified universal demonization of women.

It is telling that in this monologue, rather than use the scope of mankind's sin to cover his own, Penitent uses his individual fault to launch into this larger problem in gender dynamics. After he asks for Mistress Harebrain's forgiveness, he goes on to ruminate on how the immoral desire of men create immoral women, who men then use as emblems of the entire female sex to

\footnotetext{
${ }^{112}$ My argument here calls into question those of scholars like Robert L. Root Jr., who, like Charles Hallett and Herbert Jack Heller, suggests that the succubus does not play a significant role in Penitent's conversion; rather it is merely a device to "test his resolve" (85).
} 
justify subverting them under patriarchal authority and power. When he asks "what lecher knows when he clips his whore", it is significant that he refers to man not as himself, but by the name of his sin, just as previously, women were equated with sin itself. Rather than align women with the devil, as the successive wording in his encounter with the succubus seems to do, here, "the devil" lies alongside man's "parts", indicating that the demon with which one must contend is not women, but the urges of his own pulsing libido. Furthermore, the possessive use of "his" indicates that the responsibility for the whore lies with the man who keeps her, indeed who makes her. This is reiterated further on in the speech when he claims that it is the man who "keeps a quean" among a "table of his friends" and so makes her "more common". The implication here is that women are not whores by nature, but transformed thus by the men who keep them and share them, and so make them common, when they might have been otherwise. The word "keep" also connotes a similar kind of possession to the "his", which implies that the woman herself lacks agency in this transformation; rather, she is rendered passive, is kept and so is made into the overly sexual trope that men then dispense widely as an inherent truth of female nature. Following the acknowledgement of his own guilt in the Harebrain affair, this larger reflection on the roles that men play in both demonizing women, and in creating the stereotype of woman as she-devil who must be demonized, indicates that Penitent recognizes that his lust similarly sought to "keep" Mistress Harebrain, and so turn her from a virtuous woman into a fallen quean.

Penitent implicates himself among the overall male populace that fabricates a role for women which justifies their sociopolitical suppression under the authority of men —an introspective revelation which calls into question the entire foundation upon which the early modern gender hierarchy is based. I argue that he is only able to do so because of his encounter 
with the succubus, a literal she-devil that manifests the demonic female stereotype Penitent himself spouts in the monologue prior. By simultaneously embodying a hyperbole of that stereotype and challenging Penitent on his role as the catalyst for the overt sexuality of which women are often accused, the succubus succeeds in prompting a psychological upheaval in Penitent's perception of his responsibility in the affair. Despite my doubts about his claim that Penitent's conversion is a "grotesque...stage action", I believe that Stephen Wigler is astute in observing that this "grotesque shift [from] a farcical denial of human responsibility" to an "impassioned assertion of such responsibility" provokes an anxiety in the audience and "reveals our own conflicting feelings" about human sexuality (26). The anxiety Middleton's play provokes evidently relates to an uneasiness about the truth surrounding sexuality in seventeenthcentury England - that it is an ingrained physical and psychological element of every person, male and female. Furthermore, the repression of the truth, or the existence, of sexuality, whether for religious or cultural reasons, results in a problematic projection of an individual's desire onto undeserving targets, who then become victims of widespread sociocultural persecution. Ron Huebert perceptively identifies this morale in Middleton's play: "he is serving a warning, not about what will happen to sinners in the hand of an angry God, but about what we are capable of doing to one another and to ourselves" (qtd. in Heller 43). As such, Penitent is not the young man mercilessly pursued by an aggressive, demonic female that we see in the 1683 pamphlet. Unlike the pamphlet's author, Middleton does not make Penitent the victim, or allow his role in the encounter to go unquestioned. Rather, A Mad World, My Masters uses the supernatural to break down conventional stereotypes in gender relations, and in so doing, the play investigates the critical role psychological desire plays in manipulating contemporary gender, and subsequently power, dynamics. 


\section{$\underline{3.5 \text { Coda }}$}

Marlowe's Doctor Faustus and Middleton's Penitent Brothel are similarly complex characters, whose different encounters with the demonic both raise critical questions about prevailing cultural and religious schema in early modern England. But there are several additional subtleties that make Doctor Faustus and A Mad World, My Masters productive comparisons. For example, it is intriguing that in the scenes which most clearly demonstrate the problematic nature of the characters' psychological approaches to their respective situations, both Faustus and Penitent use literature as a base from which to launch their own musings. In Faustus' first monologue, where he attempts to "settle" his studies, he physically refers to one book after another as he moves through discipline after discipline in his catalogue of mastery. From Aristotle, to Galen, Justinian and Jerome's Bible, ${ }^{113}$ Faustus successively tosses each work aside to signify his ennui with the academic texts to which he has become so accustomed. It is particularly significant that with the last item, Jerome's Bible, he quotes a section which serves a strategic psychological purpose; as I discussed previously, Faustus' intentional omission of the full passage allows him to justify turning towards magic if he is reprobate anyways. However, Faustus' train of thought following the citation demonstrates an evasion of individual accountability and responsibility in his eternal fate. For the lines of scripture that Faustus omits after "we must die an everlasting death" read "but the gift of God is eternal life through Jesus Christ our Lord" (AI.i.n 39). By excluding the latter half of the passage, Faustus purposely ignores the fact that salvation is possible, but one must look to Jesus in order to achieve it. This complicates Faustus' desire for knowledge through occult means, so by manipulating the

\footnotetext{
${ }^{113}$ See AI.i.5-37
} 
literature to suit his own purposes, Faustus seeks to purge himself of an uncomfortable truththat the lure of the devil is more enticing than living a life according to God's laws.

Penitent, too, begins his monologue in Act Four reading. While the text does not specify the name of the book, the line Penitent cites implies that like Jerome's Bible, it is one of moral instruction: "Adultery / Draws the divorce "twixt heaven and the soul" (IV.i.1-2). After repeating this line, Penitent immediately begins his lamentations on "accursed man", and so subsequently invokes his third person sermon on human depravity. Like Faustus, here Penitent manipulates the literature in his hand in order to suit his larger agenda. He speaks not on his own adultery, but turns the matter into a universal one, a vice of which everyone is guilty. He then goes on to specify that the true culprits are the women who entice men to sin, thereby removing himself further from the position of blame. In both cases, Faustus and Penitent seek to justify their own immoral choices - to themselves more than anyone else — by presenting evidence from seemingly religious, and so presumably authoritative, sources. However, in both plays the very authority of those sources begin to crumble alongside the psychological stability and certainty of the characters who rely on them. In Marlowe's play, the spiritual presence of hell and heaven, devil and angel alike prove to be catalysts for the breakdown of individual selfhood, to the extent that Faustus prefers earthly salvation to a spiritual afterlife at the end. In A Mad World, the very male-centric systems which dominate the creation and dispensation of even the most moral literature come under scrutiny. Both cases exemplify Cooper's observation that:

the drama in Marlowe's time became more ornately self-reflexive, and morally inconclusive, by revealing that cultural forms like the drama are implicated in and beholden to the promulgation of particular ways of ordering and representing the confluence of conditions, material and spiritual, that come to bear on an individual's sense of self, and to subsequent choices they make as a result (11). 
Just as Doctor Faustus and A Mad World, My Masters are entrenched in conventions of the early modern English culture in which they were produced, so do their playwrights use the dramatic medium to critique and challenge those conventions using the creative, and often controversially subversive, expression the stage allows. On the contrary, didactic pamphlets, such as those from Spreyton and Badger-Alley, must resist similar modes of critique because their rhetoric is motivated by the same widespread beliefs that Marlowe and Middleton seek to question.

In demonstrating how sixteenth and seventeenth-century customs problematically skew individual beliefs about sociocultural practices, both Marlowe and Middleton make notable use of the figure of the succubus in particular. While I have discussed in depth the role of the succubus in Penitent's unconventional conversion, it is important to highlight that, just as both characters enter key scenes reading, so, Faustus, too, encounters a succubus in the likeness of Helen of Troy. Mephistopheles conjures the image to divert Faustus' thoughts away from his conversation with the Old Man in order to tangle him further in the devil's snare. But the succubus itself is significant, as it embodies the very thing that Faustus seeks but cannot realistically have. The fact that he engages in sexual intercourse with it demonstrates that there is a physical sensuality, even a solidity, to the demon that Faustus can corporeally penetrate. Thus, the succubus literally represents sensual knowledge through occult means - the very thing that drives Faustus towards conjuration in the first place. However, just as the image of Helen is a mere illusion, so, too, does Faustus eventually realize that his ambitions are misdirected, as his sense of self and the stability of his mind would have fared better had he aimed them at the material world. In the case of Penitent Brothel, the succubus similarly manifests the dual nature of 
his desire and his error-embodying the woman willing to succumb to his sexual whims, and eroding the illusion that he can escape the affair without admitting his part in it. Both plays use the figure of the succubus, and devils more broadly, to critically evaluate the problematic misinterpretation and displacement of male desire. While Penitent undergoes psychological conflict in being forced to confront his role in propagating negative female stereotypes, Faustus' yearning for knowledge beyond his means results in an internal struggle between damnation and salvation, which reveals the psychological instability inherent in the uncertainty of the afterlife found in widespread ideas like Calvinist election and predestination. By demonstrating the harrowing effects such beliefs could have on the ability to form individual, rational views, Doctor Faustus and A Mad World, My Masters question the reliability of accepted ideas surrounding gender and theology which shaped the organization of early modern English society. 


\section{Chapter Four Early Modern Manhood and the Making of a Witch}

As in the case of devils which posed a similar threat to Catholics and Protestants alike, so witches, too, as agents of the devil, were shared enemies across religious factions. James Sharpe notes that "despite differences in emphasis, Catholic and Protestant demonologists shared much theological ground in common in discussions of witchcraft" (80). In particular, rulers of both sects were similarly concerned with "ideological conformity and political obedience....and the position of witchcraft on their respective agendas had no obvious connection with the side of the religious divide on which they stood" (80). Witchcraft in early modern England, then, was a public issue, regardless of a person's religious beliefs. However, as Sharpe suggests, viewing the witch solely through a theological lens risks omitting the equally, if not more significant, role (most often) she played in larger political schemes. The shift from the witch as a figure of (im)morality to one concerned with broader contemporary issues of state is evident in the fact that after the 1563 statute against witchcraft, witch trials moved from church to secular courts (Levack 100; Notestein 5). Under the inquiry and examination of aristocratic judges, the witch trials became more than a means to root out spiritual transgressors; they were necessary procedures to ensure and maintain the political stability of the realm.

It is arguably because of these trials that we have more early modern records of witch activity than any other supernatural entity. However, these records largely constitute confessions from women accused of engaging in witchcraft, taken from their legal examinations. But, as in the documents analyzed in the previous chapters, the widely circulated pamphlets and tracts on witchcraft which resulted from these trials and examinations were inherently problematic because of the bias with which they were imbued, as well as their potential for misinformation. Marian Gibson notes that "the legal documents and pamphlets concerning witchcraft cases, 
which we use as part of our foundation for understanding witchcraft are...flawed...some of them are as fictional as Macbeth itself" (41), and in some of them, legal documentation "merges with narrative" (43). The skewed basis of this information thus forces us to call into question the nature of truth in and credibility of traditional sources upon which we rely to ascertain how witches operated in sixteenth and seventeenth-century England. It is my contention that if, indeed, supposedly legitimate mediums are tainted by their relation to narrative, then, conversely, we might look at dramatic narrative to provide a more legitimate portrayal of the impact the figure of the witch had on those she encountered.

The intellectual and critical credibility of contemporary pamphlets on witches is further limited by their tendency to consider only the confessions and examinations of the accused, omitting much detail about the accuser and/or the nature of their interactions with the alleged witch. This is significant because, as Peter Stallybrass notes, "witchcraft beliefs are less a reflection of a real "evil" than a social construction from which we learn more about the accuser than the accused, more about the social institutions which tolerate, encourage and act on these accusations" (190). To leave out the tale from the accuser's perspective is to limit the pamphlet's potential for critical evaluation, and such strategies reveal the author bias of those who attempt to use their tracts as a way to reinforce popular opinion on witches as the Other against which the rest of society must unite. This, as I will discuss in conjunction with my literary analyses, seems to be the case with John Darrel, who prematurely concludes his retelling of William Somers' encounter with a witch, as well as his subsequent witchlike activity, in order to shape his own persona in the eyes of his readers. But early modern playwrights like Shakespeare and Thomas Goffe take up the questions that such pamphleteers work to subvert, namely those which risk 
unearthing uncomfortable truths about the way social institutions like the church and state use the figure of the witch as a scapegoat for their own controversial value systems.

This chapter will look at how Macbeth and Goffe's The Tragedy of Orestes ${ }^{114}$ uses witch characters to deconstruct patriarchal values of masculinity that are rooted in violence and aggression. Susan Amussen argues that there were two categories of early modern manhood: the "traditional" mode where masculine self-assertion and the preservation of honour were achieved through violence, and a reformed version which emphasized self-restraint and dedication to achieving the ends of higher laws (214). According to Amussen, the latter version focused largely on self-determination and independence (227), thereby not tied to the ideals of patrilinearity which emphasized traditional models of honour and duty. But while the two categories appear to differentiate an "old" or "primitive" masculinity from a "reformed" or "enlightened" one, Amussen finds an intriguing continuity between the two in the figure of the witch-hunter. She claims that "the more they asserted the masculine ideal of independent status, the more it lead them to break laws by using torture...in the same way witches and murderers reverted to the violence of the traditional model" (227). Amussen implicitly links reformed masculinity to traditional means of violence when she emphasizes how the use of aggression is, ironically, driven by a need for self-determination. Thus, despite the supposed reformation of manly criteria, there appears to be a foundational element in the traditional, violence-based

\footnotetext{
${ }^{114}$ Several scholars have noted the similarities between Shakespeare's play and the story of Orestes, both in Aeschylus' and Goffe's versions. Debra Poole (qtd. in Showerman 29) and Robert Miola (592) both call Macbeth the "most Aeschylean" of Shakespeare's tragedies (29). Inga-Stina Eubank also observes that in Goffe's Orestes, Clytaemnestra and Aegisthus "become like the Macbeths" (qtd. in Showerman 56). Though several scholars tend to parallel Agamemnon's murderers and the Macbeths (Showerman 28-32, Miola 593), I believe that there is a fruitful comparison to be made between Macbeth and Orestes. Although one is the tyrant and one the avenger, their progressions are similar, linked by excessive violence and killing of children specifically (Miola 593). For further comparison of the plays and the primary characters, see also Seth Schein's article "Tyranny and Fear in Aeschylus' Oresteia and Shakespeare's Macbeth".
} 
masculinity from which reformers sought to separate themselves. What is more significant is the link she draws between witch and witch-hunter, suggesting that they are not dichotomous figures, but more closely connected than the witch-hunters themselves would choose to acknowledge.

It is this likeness between accused and accuser, witch and witch-hunter, transgressor and law-maker that Shakespeare and Goffe underscore through the interactions between Macbeth and the Weird Sisters, and Orestes and Canidia, respectively. In my analyses of the plays, I argue that the witch characters influence the protagonists' turns towards extreme violence by unveiling preexistent tendencies towards aggression which are rooted in the desire to secure their positions in the patriarchal structure at all costs. The result is that Macbeth and Orestes come to resemble the witches themselves in cruelty and bloodshed, which not only questions the nature of the divide between patriarchy and Other, but also challenges the values which upon which the dominant socio-political order operates. ${ }^{115}$

\section{$\underline{4.1 \text { The Witch in Early Modern England }}$}

There were several circulating definitions of what it meant to be a "witch" in early modern England. According to William Perkins in his Discourse on Witchcraft, "a Witch is a Magician who either by secret or open league wittingly and willingly consenteth ${ }^{116}$ to use the aide and assistance of the Devill, in the working of wonders" (167). Similarly, Thomas Cooper's

\footnotetext{
${ }^{115}$ Malcolm Gaskill cites Alex Shepard, who "critizes the misrepresentation of patriarchy as a crude binary opposition invariable manifested as male domination when, in reality, male gender identities covered a spectrum of feelings and deeds...masculine ideals against which men, too, found it hard to measure up" (Gaskill, "Kent" 171). I argue that these plays emphasize the problems with defining, and indeed acting on, masculinity that precludes such shows of emotion and other feminine traits which can work to temper tendencies towards vengeance - which Macbeth and Orestes both silence in forsaking fear and grief, and in excluding the counsel of the female influences in their lives, namely Lady Macbeth and Electra.

${ }^{116}$ Perkins stressed the need for the witch to willingly and rationally consent, as he did not consider those who made such pacts with the devil while not in their right mind to be truly guilty (170).
} 
tract on the devil defines witchcraft as "a wicked Art ${ }^{117}$ serving for the working of wonders by the assistance of the devil, so farre forth as God in Justice shall permit" (Cooper 47). There are two key criteria upon which Cooper and Perkins agree, the first being that the witch works only by the assistance of the devil, which she receives in exchange for binding herself to him through a pact sealed either through the promise of her soul, with gifts or with blood (Perkins 48).

Perkins refers to this pact as "the Ground of all Witchcraft" (40) wherein the witch:

As a slave of the devil, binds himselfe unto him by solemne vow and promises to renounce the true God, his holy Word, the couvenant he made in Baptisme, and his redemption of Christ; with all to beleeve in the devill, to expect to receive aide and helpe from him, and at the end of his life, to give him either body or soule or both... [and the devil] promiseth to be ready at his vassals command, to appeare at any time in the likenesse of any creature, to consult with him, to aide and helpe him in any thing he shall take in hand (48).

This covenant with the devil was the primary basis upon which witches were tried, as to abandon God was not only a theological crime, but a political one, as the king was God's representative on earth — any slight against Him was one against the monarch as well (Elmer 5). As such, James I's revised version of the statute on witchcraft in 1604 made it a new capital crime to "consult, covenant with, entertain" etc. any wicked spirits for any purpose (Walker 113), on the assumption that the presence of these spirits (including interaction with 'familiars', thought to be devilish spirits in animal form) $)^{118}$ signified that a witch had, in fact, contracted with the devil.

\footnotetext{
${ }^{117}$ Cooper refers to it as an "art" because "it hath Rules and Observations wherein it is grounded" (47), but it is a wicked art "proceeding from that roote of... a Desure to bee like Unto God" (48), stemming from "selfe love and a high concept of [one's] owne deserving" (49). I find it interesting that the characteristics Cooper cites as related to those who pursue witchcraft, and to witchcraft itself - namely, order and entitlement - are traditionally male traits, and yet women are the ones most often accused of witchcraft. Gifford, too notes that Satan looks to enlist those who are "also proud, vain glorious" (59); "his impressions print the deeper in the minde if the be fell and given to anger and ready to revenge" (59), which again is arguably a description more suited to men, especially as revenge is an inherent part of the patrilineal cycle, than to women. I argue that it is this overlooked association which playwrights unearth through their witch characters.

${ }^{118}$ In her examination, Joan Prentice 1589 confessed that the devil appeared to her at 10 a.m in the shape of a ferret, that she would have to call it forth three times for it to appear again — it asked for her soul, which she refused, but
} 
In addition to soliciting the aid of the devil, Perkins' and Cooper's definitions of the witch/witchcraft surmise that witches use this aid for the general working of "wonders". Unlike Brian Levack's somewhat historically limited definition, which outlines witchcraft as "practices of harmful, black of maleficient magic" (Sourcebook 4), Perkins and Cooper include not only maleficia, but working magic towards communal benefit as well which, nonetheless, required a contract with the devil. Demonologists did recognize the possibility that there could be both good and bad, white and black witches. According to Perkins, the 'bad' witch "consented in league with the devil to use his helpe for the doing of hurt only, as to strike and annoy the bodies of men, women and children, and catthel with diseases and with death itself' (174), while the 'good' witch, also known as cunning women/men/folk, ${ }^{119}$ "cannot hurt, torment, curse or kill, but onley heal and cure the hurts inflicted upon men or catthel by badde witches" (174). However, both Cooper and Perkins agree that these cunning people were more dangerous because "they are themselves deceived by the devil" (through practices like divination whereby they think receive divine prophecies which are only falsehoods spouted by the devil) "and so deceive others by purporting to do good" (Cooper 132). It is because of their ignorance in the harms they perpetuate that Gifford argues they, even more than the "bad" witches, deserve death (34). ${ }^{120}$

gave it blood instead (Gibson 135); Joan Cunney, when the devil appeared to her in the form of two toads, promised to do her will only if she promised her to soul, which she did (Gibson 128).

${ }^{119}$ Cunning folk were used both to find witches but also prosecuted as witches themselves, despite being known as the "anti-witch", "healer" (Macfarlane 117-118, Notestein 21-22)

${ }^{120}$ However, it is interesting to note, as Alan Macfarlane does, that "it is only when cunning folk clashed with the direct interests of other professional groups, particularly the clergy and doctors, that their activity has been recorded" (121). This accords with scholarly opinion, which I will elaborate on in the next few pages, that witchcraft accusations and trials were very much tied in to the socio-political climate, and the results of these events did depend on the state of politics, war, rebellion, occurring at the time, as they could be used as a way to bring a disgruntled country together by reinforcing conformity to social norms. 
But what qualified as "working wonders"? Perkins claimed that witches operated through two primary means: enchantment "the working of wonders by a charme" (including raising tempests, poisoning the air, killing livestock, tormenting men's bodies and calling out to devils), and iugling, "deluding the eye with some strange sleight done above the ordinarie course of nature" (i.e. creating illusion, either by conjuring a phantom image or by corrupting man's eye humours) $(127,157)$. Examples of such activity include Margery Stanton of Wimbish, who in 1579 was accused of causing local women to swell as though pregnant, making a child ill, and making cattle produce blood instead of milk (Macfarlane 83), and Alice Nokes, who in the same year was accused of betwitching a local woman to death from sexual jealousy (84). ${ }^{121}$ Cooper, however, alters Perkin's categories slightly, emphasizing Divining "whereby strange things are revealed, eyther past, present, or to come by the assistance of the Divell (129) — such as occurs with the Weird Sisters in Macbeth - and Working "which is employed in the practise and reall working of strange things or wonders" $(128)^{122}$. In addition to effecting people's physical states, Alexander Roberts also highlights the witch's ability to have an impact on the internal, "in minde, stirring up men to lust, to hatred, to love and the like passions, and that by altering the inward and outward senses... or stirring the humours" (17). The use of the word "stirring" is particularly interesting for my argument, as it connotes "bringing forth" rather than "creating", thereby suggesting that these witches unearthed feelings of lust, hatred, and other potentially

\footnotetext{
${ }^{121}$ For more detailed examples, see Marian Gibson's collection of witchcraft cases in 1566 at Chelmsford. Among these were Agnes Waterhouse, accused of keeping familiars, sending them to kill the livestock of neighbours with whom she was feuding, even to send a flux to kill one of their husband's and later, her own (18), and Ellen Smythe Mandon, accused of keeping spirits, making local children ill, taking away men's ability to eat so they died of starvation (44).

${ }^{122}$ Cooper, like Perkins, discusses charms, iugling and enchantment p. 153-171; Perkins also mentions the use of amulets, wax figures to inflict harm etc. (149).
} 
harmful qualities already present in these men, specifically_-just as I will argue Canidia and the Weird Sisters do with Orestes and Macbeth.

It is interesting to note that in his description of the witch's covenant with the devil, Perkins refers to the witch using the male pronoun. This is a bit anomalous - despite the fact that Perkins, along with other demonologists like Cooper and Roberts, concede that a witch could be male or female (168) — as it was the general opinion ${ }^{123}$ that women were most likely to become witches because "women being the weaker sexe is sooner intangled by the devill's illusions...than the man" (168). However, this turn towards associating witcheraft with women occurred specifically in the sixteenth-century; Charles Zika notes that in fifteenth-century images, sorcery was often not gender-specific, while the sixteenth-century witch "was usually depicted as a member of the quintessentially female sex, who executed power by means of complex rituals related to her female sexuality and within the context of a gendered world of agents and activities that identified her as female" (273). In his case study of the witch trials in Essex county, Alan Macfarlane found that only twenty-three of two hundred and ninety-one accused were men between 1560 and 1680 (160), and Levack concluded similarly in Europe where seventy-five percent of accused witches between 1560 and 1675 were women, with

\footnotetext{
${ }^{123}$ Cooper, too states, that witches were largely women "both because they are commonly more ignorant and therefore fitter to be ensnared... and usually more ambitious and desirous of Sovereignty" (206); Roberts agrees, writing "more women in a farre different proportion prove Witches then men, by a hundred to one: therefore, the Lawe of God noteth that Sex as more subject to that Sinne". He claims that this is the "generally received opinion" citing ancient writers like Pliny and Quintillian who write similarly (40). He adds that women are most effected because "their complection is softer, and from hence, more easily receive the impressions offered by the Divell...so consenting to the suggestions of evill spirits, become notoriously wicked, so that there is no mischiefe above that of a woman" (Robert 42), and they are "possessed of an unsatiable desire of revenge, and transported with appetite to right (as they thinke) the wrongs offered unto them" (Roberts 43). This seems ironic in light of the fact that, aforementioned, male dramatists portray revenge as an inherently male desire, which is another significant discrepancy between legal and popular portrayals of witches which I will address in my play analyses.
} 
Belgium having as high as ninety-percent (Sourcebook 133). While Perkins denies the popular idea that all witches are "aged, melancholy, weake-brained", claiming that they were "more often crafty, cunning and well aware of what they practise" (191), Macfarlane nonetheless found that in Essex, the likeliest women to be accused of witchcraft were those between the ages of 50 and 70 (161). Edward Bever, too, concludes that historically "the stereotyped old woman as witch did correspond to cross-cultural patterns of behaviour which were rooted in the interplay of sociocultural and biological influences during...life transition" (967); likewise, Levack states factually "that many poor old women, realizing their plight was desperate and believing that the Devil often offered people material pleasures in exchange for adoration, pledged their service and sold their souls to him" (Witch-hunt 18). Early modern playwrights tend to utilize this elderly female witch stereotype to varying ends, though I argue that the most fascinating portrayals, such as we see in Shakespeare and Goffe, focus not on the transgressions of the witches themselves, but of those who think themselves morally or physiologically superior to them.

\subsection{The Witch in Early Modern Drama}

The "witch" character in early modern drama takes several forms, ${ }^{124}$ and few of these character are, in fact, labeled "witch" specifically, as Canidia is in Goffe's Orestes. An example is Erictho in Marston's Sophonisba, a witch-proper in the sense of being a mal-intentioned, mischief-driven sorceress who does not yield to moral law or consequence. In other plays, like Melissa in Robert Greene's Orlando Furioso or Cynthia in John Lyly's Endymion, the witch character is called an "enchantress", more akin to a 'white' witch, whose intentions are largely

\footnotetext{
${ }^{124}$ Deborah Willis argues that the dramatic witch became a hybrid of multiple traditions, "a composite not only of the village witch, the pamphlet witch, the witch of religious tracts, but also the fairy-tale witch, the witch of ballads, medieval romance...demonological tracts, the Bible and [ancient] classics" (160).
} 
benevolent, playful even, but hardly maleficient. There is also the eponymous "wise woman" in Thomas Heywood's Wise Woman of Hoxton and John Fletcher's titular Mother Bombie, as well as Delphia — the eponymous Prophetess, who act as cunning women, sought by local villagers for their diving and/or healing abilities. Despite the multiple labels, it is evident that on the surface, these different characters can nonetheless be divided into early modern "good" and "bad" witches. However, where some scholars lament the dramatic tendency to make these witch-characters one dimensional (Willis 161) —which Deborah Willis argues is necessary in order to reduce the threat the witch poses, by making her trivial and ineffectual (163) — there are those early modern works which complicate the static witch character in order to demonstrate controversial continuities between her own questionably moral nature and that of other, supposedly admirable, characters. For example, in Ben Jonson's Masque of Queens the hags and the queens share many of the same qualities, acting as two sides of the same coin (Purkiss 188); Barbara Lewalski agrees that the queens tend to appropriate, rather than destroy the power of the hags, as they demonstrate ferocity and dominance, overturning gender norms not unlike the witches themselves, particularly in their martial abilities (29). ${ }^{125}$

However, there are scholars who overlook the more complex significance of the roles these witch characters occupy — such as Jans Frans van Dijkhuizen, who argues, somewhat narrowly, that the binary form of the masque is meant to provide a "foil against which to set off the moral superiority in the second half' (132). Bever likewise observes that most scholars,

\footnotetext{
125 James Keller notes that witches were women who rebelled against their traditional roles as mother and submissive wife (39-40). Jonson demonstrates this rebellion similarly through both the witches and the queens, thereby supporting Dawn Saliba's assertion that the "violence of the witches and the agency of the queens operate in concert as opposed to against one another" (105). The masque describes the queens in largely martial terms: "Penthesilea, the brave Amazon", "Swift-foot Camilla", "Victorious Thomyris", "Wise, and warlike...Amalasunta". This a military framework often associated with men, while descriptions of women tended to focus on the moral. However, these queens are celebrated as strong, capable rulers, and in being described in masculine terms, they become both king and queen.
} 
problematically, deny that the Weird Sisters have a causative (or overall significant) force in Shakespeare's play (164). It is my contention that, as Purkiss and Lewalski demonstrate in terms of Jonson's masque, we should evaluate these witch-figures critically, rather than dismiss them as stock characters or mere moral foils. I argue that doing so has the potential to reveal significant truths not only about the nature of early modern witch beliefs, but about the larger socio-political scheme which shapes and contains them.

\section{$\underline{4.3 \text { Witches, gender and patriarchal rule }}$}

Overall, early modern scholars of witchcraft and demonology agree that witch belief and the witchcraft trials were deeply entwined with the socio-political climate of the sixteenth and seventeenth centuries. ${ }^{126}$ Jane Miller Wanninger argues that as a category, witchcraft is best understood as "a network of tropes that are shaped by interrelated discourses of legal codes and popular folklore, and molded by the weight of superstition and convention" (57). These various discourses often came together most succinctly in the witchcraft pamphlets which were widely circulated and served both as records of ongoing trials and examinations, and ideological tools (61), reinforcing the communal need to adhere to acceptable forms of behaviour, lest others be accused of dallying with the devil. However, it is problematic that these pamphlets make up a significant portion of the historical documentation upon which scholars rely for information about early modern witch beliefs, as pamphleteers could be biased in their retellings of witch trials, particularly if they were financed by a particular patron or institution whose own views such documents would have to consider and/or reflect. Charlotte Rose Millar also notes the

\footnotetext{
${ }^{126}$ Due to the limited scholarship on Goffe's play, being a university production and not widely performed, I have decided to focus this scholarship overview on secondary commentary regarding the relationship between the witch, gender and the male-dominated state, which are issues that factor significantly into my readings of the plays in later sections.
} 
tendency of pamphleteers to intersperse their own voices into pamphlets, to recontextualize and even overwhelm the voices of the women accused; she writes,

Witchcraft pamphlets betray a multiplicity of influences, ranging from the testimony of often illiterate witches to the narrative voices taken by the pamphleteer...Pamphleteers were able to shape narratives and to choose what they included or emphasized... The pamphleteer constructing the text, then, can be assumed to have selected and emphasized the material that he...felt would be most appealing to a popular audience (16).

James Sharpe, likewise, states that "all our information on thinking about witchcraft among the population at large comes from two potentially biased bodies of source material: the records of courts and the opinions of educated observers - most prominently the clerical writers of demonological tracts", observing that it is not until the late seventeenth-century that we get a "sympathetic account" of a witch trial (58).

It is significant that the clerical classes should be responsible for many of these pamphlets as well as their circulation, as it reveals that the discourse surrounding witchcraft and witch belief was very much controlled by the upper classes; as such, witchcraft was, as Christina Larner suggests, very much an "an activity of the ruling elites...the instrument of a national state bent on imposing ideological conformity" (21-22). Robin Briggs, however, recognizes that "a very high proportion of the known...witchcraft trials were clearly instigated from below", but concedes that "this was only possible with the aid of a legal machinery established by the elites" (54). Witchcraft was thus a cultural phenomenon that operated according to the boundaries set by the highest echelons of society, but which affected people of all ranks. It was, indeed, cultural in the sense of being a general matter which encompassed religion, politics and social relations; yet, as Peter Elmer notes, it was so ingrained in the happenings at large that "no single religious or political movement monopolized belief in witchcraft and the subsequent persecution of early modern witches in early modern England" (104). However, Elmer also argues that the extent to 
which accused witches were acquitted or convicted was "largely determined by a range of factors related to the broader political climate of the day" (105) — which is evident in the fact that the two largest periods of witch hunting in England, the 1590s and 1640s, corresponded with political and religious crises (Elmer 14). ${ }^{127}$ Elmer further claims that witchcraft accusations were more likely to be taken seriously in communities experiencing high levels of religious or political conflict, as scapegoating witches allowed authorities to unite otherwise polarized factions against one universal threat (7). Monarchs, likewise, were more likely to give credence to these accusations if they felt their own power threatened, such as occurred with James VI in 1590-91 during the North Berwick ordeal, when a group of women, accused as witches, were tried for attempting to assassinate the king (Sharpe 50). This event fueled James' intense witch-hunting throughout Scotland in the 1590s and into his reign as James I of England (Levack Witch-hunt 101). ${ }^{128}$ Beliefs surrounding witchcraft were woven into all facets of society, and authorities were able to use them to their advantage, to distract from their own struggles to maintain control, by harnessing popular belief into a common threat against whom they might unite the people, who might otherwise set their sights against the authorities themselves.

This common threat these authoritative presences feared, and so against whom they sought to garner the favour of the people, most often, as Stuart Clark notes, "represent[ed] a disruption to the ideals of the hegemonic patriarchal order" ("Misrule" 98)—namely, women

\footnotetext{
${ }^{127}$ Gary Waite also notes that the Reformation signified a major change in the minds of religious and secular officials towards a willingness to be more receptive to suspicions of witchcraft, a "threat to religious, social and political authority and stability" (90) — especially as Protestantism emphasized the omnipresence of the devil, who was always looking for a way to corrupt the hearts and minds of God's people. See Chapter 3 for more information on the devil and his role in Protestant belief, particularly the doctrine of despair.

${ }^{128}$ Sharpe suggests "the most accurate interpretation of James' opinions on witchcraft would be to read them as part of his wider views on kingship" (50) - witchcraft was a crime against God and so, too, an offense against His steward on earth, charged with upholding His laws. Peter Stallybrass argues similarly about witcheraft trials being able to reinforce James' godly associations through antithesis - the more witches he was able to rid Britain of, the more godly he assumed he would seem (191-192).
} 
who either spoke out against that order, or tried to free themselves from the constraints it imposed upon them as the "inferior" sex. In their discussions on the role of gender in the witch hunts, numerous scholars cite Christina Larner's eloquent summation that they were "gender related but not gender specific" (1; Bever 955, Hall 257)_aforementioned, there were men tried as witches, but their number paled in comparison to the women accused across England and Europe. Bever notes how the period of witch belief in early modern England becomes a key point of reference for "historians of women... [who] give the persecutions an important place in women's history as part of the larger campaign to erect an increasingly patriarchal society and culture in early modern Europe" (955). ${ }^{129}$ Marianne Hester agrees that the trials were specifically an "ongoing mechanism for social control of women within a general context of...the reconstruction of a patriarchal society" (288). Not only were the victims of accusations, slander and examination often women, but Hester also highlights the fact that, despite there being large numbers of women accusing women at the local level, the witch-hunts were legislatively male dominated - it was the men who served as judges and examiners (293), and so it was men who had the final say regarding whether or not these women were convicted. This process, thus, reinforced the patriarchal hegemony which dictated how women were supposed to behave and, as Brian Levack notes, allowed the male elite to punish women who defied social norm, the "sharp-tongued, bad-tempered and quarrelsome" (Witch-hunt 152), thereby frightening the rest of the female population into upholding conventional standards of female conduct (156).

But Elmer makes an intriguing observation about the dual nature of witchcraft belief, claiming the "punishment of witches...could on occasion promote cohesion and unity in a community, reinforcing in the process the dominant political values of the ruling group. But

\footnotetext{
${ }^{129}$ Willis likewise recognizes the persecutions of witches as a pursuit of women, specifically those who were "considered to be gender transgressors, punished primarily for their defiance of patriarchal norms" (8)
} 
equally, it might serve as a vehicle for criticism and complaint, thus providing a valuable opportunity for malcontents to vent their dissatisfaction with and opposition to the ruling elite" (104). And so those women who were deemed deviant or unconventional nonetheless had the potential to use their persecution against those who persecuted them, by revealing the problematic values of the structure that put women in a particular position, and then punished them for it. For example, Hester notes that some women who did turn to witchcraft did so to push back against increasing female marginalization and social restriction; after the Reformation, productive roles for women, such as brewing and weaving, were given to men (301). Not only did they become progressively marginal figures, but they were relegated to domestic roles such as midwives, cooks, and healers - the same roles which made them primary targets for accusations of witchcraft, having access and control over various facets of a person's health (Levack 105). Moreover, women were thought to be more susceptible to the devil because of an inherent moral looseness, particularly where sexuality was concerned (Levack Witch-hunt 295); but Levack observes that such assumptions of promiscuity could be projected onto women by figures like priests who needed to cleanse themselves of such sinful thoughts by blaming others (106). Men, thus, propagated the idea that women were morally and socially inferior and so likely to engage in witchcraft - the witch, as much as she was deemed an outsider of the community, was actually born from within the community itself. I argue that it is this truth, that the witch is not an exterior threat to the patriarchy but merely an internal symptom of a larger problematic systematic framework, which the Weird Sisters and Canidia reveal through their interactions with their respective male protagonists.

\subsection{The Weird Sisters}

Between 1591 and 1592, twenty-two year old William Somers was travelling through Worchestershire as an apprentice musician, when he noticed two things along the side of the 
road: an old woman and a hat with a copper band. ${ }^{130}$ The woman asked him to relinquish the hat to her, being in need of it herself, and Somers reluctantly conceded, though he kept the copper band for himself, "suppousing it to be of gould, whereupon she threatn[ed] him said that 'it had bene as good for him to have given it her'". After this strange encounter, Somers met with several other odd occurrences. That same night "he saw a stranglight in the chamber where he lay, which cast him into a great feare, and thus he continued frighted for a time." A short time after as he continued on his travels, he found himself "suddenly throwne into a ditch" followed by a thorn bush. As he finally made his way home, "he begane to be sicke, from sicknes he came to carie himself after that strang manner by fyts". "[H]e being for the same space of three weekes or ther abouts a continuall trouble" to his master, who sent Somers to live with his widowed mother.

Some years after this period had passed, Somers began apprenticing for Thomas Porter, a weaver and a musician. On March 20, 1596, Porter sent him on an errand to Darbyshire, to the house of William Bowes and his sister-in-law, Mary Milwood. On his return, Somers again met the "auld woman who asked him where he dwelt and whither he was going." He ignored her, but met her again a mile and a half down the road, when she said to him, "I must have a penny of thee", and when he insisted that he had no money, she responded, "thou hast...Mary Milwood gave thee two pence, [and] I will have a penny of it or I will throwe thee into this pyt and breake thy necke." He quickly gave her what she asked, but as he turned to move on, she took out a piece of bread with butter from her bag and told him to eat it; when he refused, she again

\footnotetext{
130 Tale taken from pamphlet by John Darrel, entitled, A true narration of the strange and greuous vexation by the Devil, of 7persons in Lancashire, and VVilliam Somers of Nottingham Wherein the doctrine of possession and dispossession of demoniakes out of the word of God is particularly applyed vnto Somers, and the rest of the persons controuerted: togeather with the vse we are to make of these workes of God. 1600, STC (2nd ed.) / 6288, Early English Books Online. 21 Feb 2019.
} 
threatened to break his neck, thus forcing him to comply. After he had finished, Somers noticed "a catt leapt up into her bosome, which she embraced and with her armes claspt it unto her, and this they [she and Somers] parted from each other". Later that year during a gathering at his master's house, Somers began exhibiting the same kind of strange behaviour as before. He, did use such strang and ydle kinde of gestures in laughing, dauncing and such like lighte behaviour that he was ssuepcted to be madd: sundry times he refused all kind of meate....insomuch as he did seeme therby to pyne away...sometimes he shaked as if he had an ague [and] there was a strang noyse or flapping from wihin his bodye, he was often seene to father himself on a round heape under his bed-cloathes....also to beate his head and other parts of his bodye against the ground and bedstead in such earnest manner and so violentlye that the beholders did feare that thereby he would have spoyled himself if they had not by strong hand restrained him...Then... when the fit was done [he] was questioned...concernynge these thinges, whereunto he returned for answeares that which is set down in the beginninge of this storye, which he had concealed untyll that time.

It may not be immediately apparent why I would begin a chapter about witches with a pamphlet whose title indicates it is about demonic possession. But despite the fact that the pamphlet's author, John Darrel, singles out William Somers from the pamphlet's other narratives as especially exemplifying traits of possession, I think his deduction overlooks some key details of the tale which arguably point more credibly to the presence of witchcraft than of the devil himself. It is important in this regard first to note that Somers puts the old woman at the centre of his experience. At the end of the section during his interrogation, Darrel records that Somers "returned for answeares that which is set down in the beginning of the storye" - the only significant event at the beginning is his encounter with the old woman, whom he meets yet another time after — both occurrences being followed by periods of sudden fits and erratic behaviour. As for the old woman, she fulfills many of the stereotypical behaviours scholars have associated with witches in the period, the most obvious being her gender and her age. As discussed in a previous section, scholars like Alan Macfarlane and Keith Thomas have noted that 
elderly females were most commonly accused of being witches, and while more recent scholarship has attempted to broaden the scope beyond this narrow character margin, the old hag nonetheless remained, at the very least, the caricature portrayal of an early modern witch. There is also the fact that Somers observes the woman with her feline companion, a blaring referent to the witch's familiar, cats being one of the most common types (Gifford 12) ${ }^{131}$ Furthermore, in both encounters the woman tests Somers' neighbourly generosity, ${ }^{132}$ and when he denies her requests, she threatens to retaliate with malevolence. These several descriptions imply that it was indeed a witch that Somers continued to encounter, and thus it becomes reasonable to argue that the strange behaviours he experienced following these encounters were in some way related to the witch's powers and influence. However, it is important to remember that the witch was considered an agent of the devil, so Darrel is not wholly misguided when he groups Somers' tale in with stories pertaining to the power of the devil which, in this case, seems to manifest through the figure of the witch.

Darrel's retelling of the events make evident that the witch's primary effect on Somers is physical. His body is thrown headlong into a ditch, he violently beats his head on the ground, he suffers his body to deteriorate by starvation — even the old woman's threats convey physical harm, as she promises to throw him into a pit and break his neck. This concentration on affecting the body is what foremost distinguishes the old woman in Darrel's pamphlet from the Weird Sisters in Shakespeare's Macbeth. John Stachnewski notes that "the Weird Sisters...signify the tendency of the human mind to dislocate itself from the present and alienate the individual from

\footnotetext{
${ }^{131}$ In her overview of the 1566 trial and examination of Elizabeth Francis, Marion Gibson notes how the girl claimed a cat appeared to her and spoke, seemingly on behalf of Satan, as the cat itself was named Sathan. It would ask Francis what she desired, and every time she named something, the cat desired payment in the form of a drop of the girl's blood (16-17)

${ }^{132}$ Macfarlane notes that witches were known for their discontent, "a desire for revenge", greed for "such things things as they desired", and for repaying a lack of charity from their neighbours (173)..
} 
his social area and function by entertaining a personal fantasy for the future" (178). That is, they are a force which affects the mental world of the characters above all else, and their psychological influence ultimately complicates the characters', namely Macbeth's, relationship with the external world and the social, political institutions which govern it. I argue that the Sisters are able to shake the foundations of belief, which these institutions establish to serve their own purposes, because they embody alienation from the social order. As such, they unveil the traits in others which similarly violate acceptable customs of behaviour and thought, thereby highlighting the universally innate presence of the deviance they alone are thought to represent, while nonetheless tempting those affected to embrace their own darkness. In the case of Macbeth, however, his darkness becomes a symptom of a much larger problem, as his turn towards violence is motivated by a desire to exemplify a masculine ideal rooted in bloodshed which patriarchy itself promotes. The Weird Sisters, thus, are embodiments of social disorder that exist both within and outside of the patriarchal system - while their transgressions challenge early modern gender and power norms, they also reflect the system of male violence and powermongering which are foundational to patrilinearity. It is from within this system that witch-figures are created, pursued and persecuted, as a way to distract from the problems that inhere in the very fabric of institutional male authority.

\section{The Inscrutable Sisters}

When I say that the Sisters emblemize social disorder, I refer specifically to the various ways they defy the different strands of conventional thinking and belief that dominated early modern English society—from gender norms to stereotypical expectations of witchcraft. Most explicitly, they straddle gender lines, being old women and masculinized because, as Deborah Willis notes, their dry and shrivelled bodies - past the point of reproduction, no longer able to 
create life-remove them from their primary function as women (14). Willis also claims that the devil was seen as a "masculinizing super power" (150), and so the witch, by extension of her pact with him, became increasingly masculine as well. In the play, Banquo notes the gender ambiguity of the Weird Sisters when he remarks, "you should be women / And yet your beards forbid me to interpret / That you are so" (I.iii.45-47). Their physical androgyny coupled with the dominance they exert over Macbeth's psyche ${ }^{133}$ thrust them into a realm between feminine and masculine which defies traditional gender boundaries.

Perhaps more significant than their elusive gender classification is the difficulty with which scholars have tried to deduce their primary function. They are among the most cited witches in English literature despite the fact that, as Nicholas Brooke notes in his introduction to the Oxford edition of the play, the word "witch" is only actually used in the first scene of the main action (excluding stage directions), when one of the Sisters quotes the words of the sailor's wife: "“Aronyt thee, witch' the rump-fed ronyon cries" (I.iii.6). M.D.W. Jeffreys further notes that this label is used as a term of abuse, not identification (44). While there are those who argue that Shakespeare's Weird Sisters are, in fact, the "incarnations of evil" (Ribner 151) representative of the figurative concept of the early modern witch, ${ }^{134} \mathrm{I}$ am more inclined towards the observations of scholars like Laura Shamas, who claims, "Shakespeare created a mythologically complex female trio which defies precise definition" (65), and Diane Purkiss,

\footnotetext{
${ }^{133}$ Willis notes that although witches could also be associated with women and motherhood, in conformity with domestic female roles, they were often women "who stepped out of place and asserted [themselves] too vigoursly...challeng[ing] masculinity... resist[ing] ... a regressive return to dependence" (70-71) on men. Rather, these women exceeded the passive roles generally imposed on and expected of women in favour of taking active control in a way more characteristic of their male counterparts.

${ }^{134}$ Walter Clyde Curry sums up scholarly interpretations of the witches: "they have at various times been characterized as concrete symbols of that element of negation and destructiveness that is opposed to all order and growth, spirits of evil in its most malignant form, the materialisation of a spiritual cosmos of evil, Macbeth's crime nightmare projected into action, limbs of Satan, representatives of Hellish power, infernal spirits, and demons" (397), and Curry agrees that they "are intended to symbolize or represent the metaphysical world of evil spirits" (400); Jeffreys also refers to them as "the cosmic forces of evil" (53).
} 
who similarly suggests that Shakespeare makes his hags intentionally "indeterminate" figures (211). Though they do exhibit aspects of the traditional witch, keeping familiars and torturing those who deny them, ${ }^{135}$ Shakespeare also imbues them with an inscrutability by paralleling them with forces of fate. Brooke, alongside other scholars, notes the close phonetic association between "Weird" and the medieval "Wyrd" (3), meaning fate or destiny, especially as Holinshed in his chronicles described the three women who appeared to the historical Macbeth as "goddesses of destinie". ${ }^{136}$ This label seems well-suited to the role the Weird Sisters actually play in the drama - despite their casting petty vengeance on the sailor and his wife, their primary function is prophetic. The first lines in the play establish their foreknowledge, as first Sister asks "when shall we three meet again" (I.i.1), the second responds, "when the battle's lost and won" (4), and the third adds, "that will be ere the setting of the sun" (5). The uses of "when", "will" and "ere", words that connote futurity, emphasize their prophetic power. The stress Shakespeare puts on their foreknowledge is significant because it echoes the practice of Divination, which sixteenth-century theologian Thomas Cooper defines as the "conjecturing of unknowne and hidden things" (129). Cooper claims that "good witches" practice divination, and yet even those witches are "informed by Satan...probably, doubtfully, and deceitfully: and therefore must needs deceive themselves and others" (132). Cooper's explanation of divination only adds to the ambiguity of Shakespeare's witches, as those who practice it seemed to have good intentions towards their neighbours, but the power to divine was nonetheless said to come from the devil.

\footnotetext{
${ }^{135}$ In his annotation of the lines, "I come Graymalkin. / Paddock calls" (I.i.8-9), Brooke writes that the first is a name common for a cat, and that both likely referred to witches' familiars (n.8-9 p. 95). Additionally, the witches admit to "killing swine" (I.iii.2), and the murdering of livestock, particularly through disease was a common way witches were thought to reap vengeance on ungenerous or cruel neighbours (St. Clark 114).

${ }^{136}$ Discussed by both Jeffreys (44) and Andrew C. Bradley (299) in their work on the play; both cited in the Bibliography.
} 
Considering the variant nature of their character affiliation and connotation, Shakespeare makes it nearly impossible to ascertain the nature or purpose of his Weird Sisters. Purkiss suggests that the mix of classical and contemporary influences, coupled with the lack of evidence that Shakespeare made use of James' Daemonologie or any contemporary witchcraft trial pamphlets, suggests that the Weird Sisters are not meant to be a comment on early modern English witchcraft phenomenon, but rather are a means by which to demonstrate something larger (213). In what follows, I will argue that they are neither merely "Fury-like" (Purkiss 211) nor veritable agents of the devil; while their first prophecies appear morally neutral, their subsequent meetings with Macbeth indicate a deeper investment in what happens to the protagonist. However, in a surprising turn of events, the implications of their biased interest favours the well-being of Scotland over the desires of the tyrant who invests so much in them and their prophecies.

"Are you a Man?"

While I think it is reductive to view the Sisters as mere "evil incarnations", they do, nonetheless, ensnare Macbeth through temptation. However, even this does not prove their motivations are of the Devil, since, as David Kranz notes, they appear to be "the essence of forces in the world that work against the rational God", and yet their consistent alignment with the fates makes it so they cannot be wholly opposed to God, who is the fate-maker (350). In this way, they are perhaps agents of both God and the Devil, ${ }^{137}$ and so the temptation they manifest in Macbeth is a moral test whereby the Sisters' prediction that he will be "King hereafter" (I.iii.50) forces the protagonist to confront his dark desires for a possible future that he himself has

\footnotetext{
${ }^{137}$ Alternatively, they may exist outside of the Christian moral universe altogether-hailing from the world of pagan belief as Furies of destiny. Nonetheless, their prophecies point towards Macbeth's true, violent nature, as his automatic inclination is to murder - they, therefore, light the way for Macbeth to expose his internal darkness, or challenge him to fight it.
} 
already considered. Indeed, numerous scholars have observed that in this first encounter, the Sisters do not plant seeds of corruption or murder in the mind of Macbeth - it is important to note, as both Alan Morris Cochrum and George Walton Williams do, that "thou shalt be King hereafter" predicts nothing of Duncan's murder ${ }^{138}$ — but rather, they unveil the dark potential already lurking beneath the appearance of the loyal warrior subject. ${ }^{139}$ Such is evident in the rapidity with which Macbeth contemplates killing the king in order to see the prophecy through: "Why do I yield to that suggestion / Whose horrid image doth unfix my hair / And make my seated heart knock at my rib / Against the use of nature? ... (I.iii.135-38) Andrew C. Bradley argues that Macbeth's reaction to the prophecies indicates that he is not an innocent man, as "no innocent man would have started, as he did, with a start of fear at the mere prophecy of a crown, or have conceived thereupon immediately the thought of murder" (301). The "suggestion" to which Macbeth claims to yield truly is none but his own, as aforementioned there is no such suggestion even implicit within the prophecy itself.

Katherine Woods observes that after hearing the prophecies, Macbeth's "very identity as a brave man loyal to the king is thrown into flux as he is offered an alternative channel for his ambition and bloodthirstiness" (187). Indeed, the first encounter with the Weird Sisters starts Macbeth on his psychological, physical and political journey from king's man to king's slayer, and his overeager tendency to yield to the non-suggestion of the Weird Sisters indicates his willingness to cede to them from the beginning, which foreshadows the faith that he will put in them and their prophecies, even above the laws of God and justice, as the play progresses. Like Hamlet's initial interrogation of the ghost, so Macbeth asks the hags, "are you ought / that man

\footnotetext{
138 See Cochrum's dissertation chapter on "the Weird Sisters as False Prophets" and Williams' "Macbeth: King James' play” South Atlantic Review, vol. 42 no.2, 1982, pp.12-21.

${ }^{139}$ Katherine Woods agrees, that like other witches on the early modern stage, the Weird Sisters, too, "appealed to the appetite" (298), thus bringing to the forefront Macbeth's pre-existing desire for the throne.
} 
may question?" (I.iii.42-43) While Banquo's own rational skepticism ${ }^{140}$ is evidence that yes, indeed, the Sisters may and perhaps should be questioned, especially considering the ambiguity of their nature and origin, the tone of Macbeth's own query here suggests that he is in fact, questioning those who would challenge them. The word "may" connotes a kind of permission, that to confront the Sisters as liars would require going beyond acceptable protocol—as though the default reaction should be to believe them. His eager reaction to the prophecies is evidently at odds with Somers' own when the old woman demonstrates divinative knowledge in her awareness that Mary Milwood gave him money. However, unlike Somers, who cedes to the woman's request out of fear, Macbeth yields, unprompted, to the possibilities that aligning himself with the witches and their prophecies might have for him. While the old witch has to force Somers to take what she offers (the bread and butter), Macbeth is ready to eat up whatever the Sisters have to say without second thought. Herein lies the difference between the two: Darrel positions Somers as a victim of evil circumstance, while Shakespeare suggests that Macbeth takes his encounter with the Sisters further than they may have ever intended.

But while the Weird Sisters give voice to Macbeth's own desires for power, and this can be said to contribute to his willingness to dispense with rational skepticism in favour of taking them at their word, I would suggest the prophecies unearth something even more innate than the desires themselves - that is, the identity crisis which drives the violent action he is willing to undertake to attain them. Woods astutely observes that Macbeth is foremost "a play about identity that questions what it is to be a man" (181). Ideas of manhood and manliness in the play, however, become problematic symptoms of a patriarchal system that values power above all

\footnotetext{
${ }^{140}$ Banquo repeatedly expresses concern over trusting the words of the Sisters, warning "oftentimes, to win us to our harms / The instruments of darkness tell us truths, / Win us with honest trifles, to betray's / In deepest consequence" (I.iii.124-27)
} 
else, and so implicitly condones, even encourages, violence as a means of obtaining it. Jarold Ramsey claims that Macbeth "is forced to accept a concept of manliness that consists wholly in rampant...aggression" (289), and Robert Kimbrough likewise argues in the play "to be 'manly' is to be aggressive, daring, bold, resolute and strong" (177). Macbeth's dark desires for power at any cost are, thus, not a result of a corrupt individual, but rather the by-products of the “chauvinistic war ethic of his culture” (177). Caroline Asp further notes that Macbeth would have been enmeshed in this culture of manly aggression from his early years, to the point where such violent inclinations would seem natural, as "in the play the male stereotype is associated with violence made socially and ethically acceptable through the ritual of warfare" (154). Thus, the action "against the use of nature" quoted above would be the usurpation of a divinelyordained monarch, rather than the act of killing itself.

It is, however, intriguing to note how the connotation of blood spilled in war changes as the play progresses. Woods notes that in the first act, the spillage of blood is what defines Macbeth as a loyal and fierce warrior, "since it denotes the violence of war and is acceptable and honourable within the symbolic structure of enmity"; but, when Macbeth uses the same violent means to kill Duncan, the spilling of the king's blood "signifies rebellion against the dominant patriarchal order of the play" (183-84). The play suggests a subtle parallel between the two bloody affairs at the very beginning when the captain recounts Macbeth's action in war against the traitors MacDonwald and Glamis: "brave Macbeth... / Disdaining Fortune, with his brandished steel / which smoked with bloody execution / Like Valour's minion carved out his passage" (I.ii.6-9). Here, the captain hails Macbeth's "bloody execution" as brave, and it renders him a champion of valour, particularly because he "disdain[s] Fortune, with his brandished steel"- which suggests that through the use of his sword, Macbeth was able to manipulate the 
fate of the war in the king's favour. Is not his murder of Duncan also a bloody execution? Does he not similarly disdain Fortune by taking the issue of prophecy into his own hands, and again, using instruments of violence? By implicitly paralleling the initial act of war with the one Macbeth will eventually undertake, the first act "simultaneously establishes masculine authority and the instability of its structural dominance. Consequently, the images by which masculine authority asserts itself, through swords and blood, decapitated heads and smoking steel, hold within them the potential for anxiety" (Woods 188). That inherent anxiety is rooted in the nonending cycle of violence that upholds and defines patriarchal structure - that the bloody action one man performs for his own political right, may yet be used against him for another to assert his.

However, as is evident in the way narratives, historical, dramatic or otherwise, can frame blood spillage in particular ways in order to favour dominant ideologies, so Stuart Clark notes that Macbeth concerns itself with vision, sight and perception, and how the way we see things might be skewed to undermine ethical judgements (Vanities 278). Because he chooses to interpret the Sisters' prophecies as undisputed truths which will and must come to pass, Macbeth allows himself to be guided by this singular idea to the extent that he becomes divorced from the conventional way of seeing things as right or wrong (236). He is literally lead by thoughts of the prophecy when he encounters the phantom dagger on his route to murder Duncan. In his soliloquy, Macbeth implicitly connects the apparition to the Sisters and his earlier encounter with them; just as he quickly yielded to the suggestion he reads in the prophecies, which, I have argued, is evidence of his already-existing desires to usurp the throne, so the dagger, too, "marshall'st me the way I was going" (II.i43). He further refers to the dagger as "an instrument" (44) similar to the Sisters themselves, so-called "instruments of darkness" (I.iii.125) which, like 
the dagger, do not create Macbeth's murderous desire, but merely manifest the means by which he might fulfill it. But the end of the speech demonstrates that Macbeth is yet unwilling to yield accountability for his dark thoughts, as he claims that "witchcraft celebrates / Pale Hecate's off'rings and withered murder" (II.i.52-53). The implication is that the way forward which the phantom dagger "marshall'st" coincides with the intent of the Sisters - Hecate's messengersand so murder becomes supernaturally sanctioned by the representatives of Fate. However, what Macbeth fails to perceive is that he is the one eagerly taking up the prophetic offerings of the Sisters, and while the three never advocate for murder, it is Macbeth himself who hastens to consider it — as it is he, not the Sisters, who will immediately benefit from the king's death. What he would label as the aim of witchcraft, then, is revealed to be the manifestation of his own desires which he attempts to displace onto the Sisters as his guiding force, in order to shelter his psyche from the horrifying truth of his own malevolence. He gestures towards the ways men manipulate such circumstances in their own favour when, even before the dagger appears to him, Macbeth notes, "we but teach / Bloody instructions, which being taught, return to plague th'inventor" (I.vii.8-10). Here, the emphasis on we implicates Macbeth himself, and the patriarchal system he serves and represents, in first dispersing the bloodshed and violence of which they then accuse others, namely witch-figures like the Weird Sisters. For even though Banquo tells the Sisters that he "neither beg[s] nor fear[s] / Your favours, nor your hate" (I.iii.6061), the play gradually reveals that the "hate", cruelty and other such depravities of which witches are accused do not originate with the witches themselves, but with the men who accuse them.

Indeed, such violence becomes necessary in order for one to remain at the height of the power structure. As Asp claims, the idea of manliness must "exceed the limits of soldierly valour 
and embrace the extreme of retaliatory violence" (Asp 155). Furthermore, because of the anxiety of overturn inherent in this cycle of patriarchal power, Asp notes that this concept of manliness is not a fixed state, but something that must continually be proved through "manly deeds" (155). Willis acknowledges as much when she claims that Macbeth's journey, and his eventual destruction, is "enacted through encounters with a series of [male] rivals", and the prophecy of his success and power is "imbued with his displacement from power, embodying a truth that Macbeth knows, partly denies, and then comes to feel persecuted by" (218). Kingship, a concept based in inheritance, is thus constituted by both the rulers who came before and those who will come after - a cycle which depends on the substitution of one man for another. Macbeth's fear of his own usurpation, and of the overarching anxiety of violent replacement and redistribution of power inherent in the system of which he is part, is evident in the language of unseating interspersed throughout the play. When the ghost of Banquo appears, Macbeth notes that "the table's full" - a result of the dead that "rise again / ... / And push us from our stools" (III.iv.46, 81-83); again, as he approaches the final battle, Macbeth reflects that the final "push / Will cheer me ever, or dis-seat me now" (V.iii.20-21), with cheer glossed as a pun on chair (Macbeth n.21 pp. 199). It becomes evident that just as Macbeth's initial action against Duncan is motivated by a deep-rooted desire for power, so the violence that results stems from his desperation to maintain the power he transgressed God's laws to obtain in the first place. He indicates as much during his scheme to murder both Banquo and his son, Fleance: "to be thus [king] is nothing / But to be safely thus" (III.i.47) — he stakes the success of his tenure as king on his ability to maintain his crown, and to prevent potential rivals, particularly unnatural successors, ${ }^{141}$ from

\footnotetext{
${ }^{141}$ Macbeth emphasizes this in his monologue in III.i, where he expresses his distress at the part of prophecy that named Banquo's issue future kings: "under him, my genius is rebuked... / ... / Upon my head they placed a fruitless crown, / And put a barren sceptre in my gripe / Thence to be wrenched with an unlineal hand / No son of mine succeeding" (III.i.54-55, 60-63). The use of "unlineal" particularly highlights the need for patrilinearity, to maintain
} 
taking it. After the apparitions from the cauldron caution Macbeth to "beware MacDuff" (IV.i.85), his focus returns to issue of lineality, as he cites specifically "his wife, his babes and all unfortunate souls / That trace him in his line" (IV.i.167-68). It is not only MacDuff that he must exterminate, but the whole clan of potential traitors that might seek to rise against the tyrant as vengeance for the slain. If violence is the means by which one might prove his manhood, then violence must be the means by which one retains it, and in the quest for patriarchal power, the murder of innocents, guilty only by familial association, becomes a necessary precaution in order to maintain both power and the claim to masculinity.

There are characters in the play, however, who seem to challenge this assessment of what it means to be a man in Shakespeare's Scotland. Duncan, for example, speaks as a kind king, who praises the actions of his soldiers, ${ }^{142}$ and yet remains at a distance from the bloody violence of the battlefield. He receives report of the action from a captain who recalls the great victory as well as Macbeth's pivotal role in it. And he is of such virtuous character that Macbeth acknowledges that he "hath borne his faculties so meek, hath been / So clear in his great office, that his virtues / Will plead like angels" (I.vii.17-19). Evidently, Duncan is a much loved king on earth and in Heaven, and his "meekness" opposes the violence that surrounds him. However, Duncan is nonetheless a man who benefits from, and thus is implicated in, the system of bloodshed inherent in patriarchal authority. After all, the "bloody m[e]n...report" (I.ii.1) to him, and he rewards Macbeth's violence with the title and lands of the Thane of Cawdor- "what he hath lost, noble Macbeth hath won" (I.ii.68) — thereby positively reinforcing bloodshed as a

\footnotetext{
power through physiological means and natural inheritance, so to prevent the kind of violent usurpation and vying for power which Macbeth himself performs.

${ }^{142}$ Hearing of Macbeth's triumph, Duncan exclaims, "O valiant cousin, worthy gentleman!" (I.ii.24); he finds "Great happiness" (59) in their victory, and expresses sincere gratitude to Macbeth for defending his kingship so successfully (I.iv.13-21).
} 
means of gain. Furthermore, Duncan's "manliness" is questionable in the realm of the play, as not only is "meekness" is a traditionally feminine trait, but Duncan also relies on the violent action of his soldiers to protect his person and his crown. He asks his son, "is the execution done on Cawdor?" (I.iv.1), demonstrating his expectation that violence take place to his benefit, just not by his own hand. Moreover, Duncan's inability to protect himself makes him an easy opponent to overtake, and the play questions whether his "meekness" in fact contributes to his downfall. Perhaps if he were all the more the man, according to the play's definition, he might have been more attuned to the precarity of his position, and so fared better against power-hungry conspirators.

Like his father, Malcolm is similarly effeminized throughout the play. However, Malcolm becomes a poor potential substitute for his father, which suggests he will make a weak king, and so give rise to subsequent rebellions by "stronger" men — thus perpetuating the cycle of male violence for the sake of power. It is telling that at the start of the play, Malcolm is by his father's side at court rather than on the battlefield. Marina Favila underscores that war in the play becomes a kind of bloody rite of passage, claiming that "the battlefield...is the birthplace of manhood" (5). ${ }^{143}$ Just as a girl became a woman through menstrual bleeding, so, too, did young boys need to be blooded in order to become men. Malcolm, however, does not successfully undergo this transition, as he is soon in danger of capture, and, like Duncan, requires the labour of other men to save him. ${ }^{144}$ Instead of confronting the rebellion against his father head on, he relies on hearsay of those who have, admitting, "I have spoke with one who saw him [Cawdor]

\footnotetext{
${ }^{143}$ Janet Adelman similarly argues that Macbeth wields the bloody axe in an attempt to escape the maternal presence of birth and instead reimagines the birthing process of man as a violent emergence, which is why Macbeth must "manage by hewing his way out" into the world (36)

${ }^{144}$ He recognizes the captain who comes to report as "the sergeant / Who like a good and hardy soldier fought / 'Gainst my captivity" (i.ii.3-5).
} 
die" (I.iv.3-4), because he was not there himself to witness it. Furthermore, on hearing of his father's death, Malcolm's automatic impulse is to retreat to England for his own safety. Though his decision is arguably justified under the suspicious circumstances of his father's death, the action of retreat is nonetheless arguably "meek" in comparison to the revenge one would expect from a son whose father had been murdered. When it does come time for Malcolm to enact revenge, his speech is riddled with words of strong emotion rather than aggressive action, bemoaning the country that "weeps...bleeds" (IV.iii.40), and needing MacDuff's "noble passion" to "wipe[ ] the black scruples, reconciling....thoughts / To...good truth and honour" (IV.iii.114-17). His reliance on others extends to the battlefield itself, where he notes, "I would the friends we miss were safe arrived" (V.vii.65)—-he looks to reinforcements to secure victory rather than to his own power and ability. And, in the end, it is MacDuff who kills the tyrant, MacDuff who delivers Malcolm his crown. It is for this reason that, even at the end, Macbeth refers to Malcolm as "the boy", "lily-livered boy" (V.iii.3, 15), because the play itself hardly portrays him as anything more.

\section{The Power of Fear}

The violent aggression which constitutes what it means to be a man in the play becomes so dominant as to discourage thoughts of inaction, which suggest weakness and risks emasculation. But to kill is not enough to earn and maintain manhood. One must also suppress other innate inhibitors to performing the violent action masculinity requires - namely, femininizing influences. For Macbeth, this means defying his wife's attacks against his manhood by seeing the murder of Duncan through, ${ }^{145}$ as well as quelling the fear that seeks to undermine

\footnotetext{
${ }^{145}$ When Macbeth decides "we will proceed no further in this business", insisting that by staying his hand, "I dare do all that may become a man / Who dares do more is none" (I.vii.31, 46-47), he seems to momentarily challenge the tie between manhood and violence, suggesting that to kill Duncan would be an excessive act that would extend beyond the barriers of man, into the realm of beasts. ${ }^{145}$ However, his resolve can only ever be fragile because he is
} 
his resolve. Banquo highlights Macbeth's tendency towards fear near the start of the play, as after the Sisters depart he notes that his friend seems to meet the prophecies "with fear / Things that do sound so fair" (I.iii.51-52). Here, Macbeth's fear signifies a kind of rational skepticism of the Weird Sisters and their words, which he loses as he becomes more consumed by and reliant on their prophecies. Seth L. Schein observes similarly that Macbeth's doubts and fears "are one of the best things about him...a sign of his morality [while] his denial of fear later on in the play...signifies an emotional and moral paralysis resulting from his embrace of evil" (97-98). Schein refers most poignantly to Macbeth's fearful reaction to the ghost of Banquo. His initial response to the spectre is to deny responsibility for the act_- "thou canst not say I did it" (III.iv.50)—which indicates his terror at any retribution the ghost might perform. He reiterates his denial as a fragile defense against the fear that risks overtaking him when he says, "why what care I if thou canst nod, speak too" (70). The truth, of course, is that Macbeth cares very muchas much is evident in the powerful affect the ghost has on his external and internal demeanor, not only appearing visibly eccentric in front of his banquet guests, but also forcing him to confront the guilt of murdering his friend. ${ }^{146} \mathrm{He}$ must quell his fear, however, if he is to seem manly; Lady

already enmeshed in a culture that supports the opposite view-indeed, he himself as a soldier and fierce warrior, a killer of men by trade, has already been a participant in it. Lady Macbeth knows this well, and uses her words to trigger the warrior pride in her husband, which the play demonstrates from the beginning is the mark of his identity as a man. She rebukes his reconsideration of the deed, telling him "when you durst do it, then you were a man; / And to be so much more than you were, you would / Be so much more the man" (49-51). Here, she suggests that the degree of his manhood rests on his ability to kill the king, as not only would doing it make him a man, but so much a man that none would dare question his masculinity again, as she does now. However, refusing the deed indicates that Macbeth would be happy to "live a coward in thine own esteem" (43); she hits on both the soldier's need for valour, of which cowardice is the ultimate enemy, and on his desire to be held in high repute. Killing the king becomes another act of war not unlike the ones Macbeth begets praise for at the start of the play-she indicates as much when she asks him "art thou afeard / To be the same in thine own act and valour" (39-40), as the mention of valour specifically harkens back to the captain's description of Macbeth as "valour's minion". To kill is to earn valour, and to shirk from the task is to denounce it.

${ }^{146}$ In his first aside after the ghost appears, Macbeth recalls "Blood hath been ere shed now... / ... / Ay, and since, too, murders have been performed / Too terrible for the ear... / ... / This is more strange / Than such a murder it" (III.iv.76, 78-79, 83-84). He indicates that although murder has been committed before-which reiterates the violence of this patriarchal society - none have birthed the terrifying anomaly that is the ghost. This suggests that the crime Macbeth has committed is extraordinary in its immorality to prompt the ghost of his friend to rise to haunt him. 
Macbeth indicates as much when, seeing his first frightened visage, she scolds her husband, "are you a man?" (57), suggesting that his show of fear indicates that he is not. Macbeth himself implies a similar parallel when, after the ghost vanishes, he says "I am a man again" (109), as though the fear he experienced in the presence of the ghost had temporarily taken his manhood from him. After this episode, Macbeth's increasing belief in the delusion of his own right to power, and his elevated willingness to use bloody methods to keep his throne, negatively correlate with his expressions of fear. It is as though, according to Adelman, "bloodthirsty masculinity...seems to promise an escape from vulnerability" (43). ${ }^{147}$ As he faces down his approaching enemies in the final act, he still refuses to give in to fear, sending away the servant whose "linen cheeks / Are counsellors to fear" (V.iii.16-17), and threatening to "hang those that talk of fear" (V.iii.35). He insists on subverting the feminizing emotion that has sought to consume him from the beginning in order to maintain his manhood until, and especially when, it seems to be all he has left. However, just as Somers" "lighte behaviour" made others suspect "him to be madd", so, too, does Macbeth's increasing indifference to fear correspond with his gradual descent into madness, which, as I will discuss, manifests as his obsession with maintaining his position of power.

By burying his fear, at the cost of suppressing, too, his more rational inclinations, Macbeth feeds his obsession with his masculine power, and as such, invulnerability, to the extent that he guarantees his downfall. For example, his failure to interpret multiple meanings in the apparitions that manifest from the Sister's cauldron creates a false sense of security which

\footnotetext{
${ }^{147}$ Macbeth further expresses his intent to carry out such violence rashly in order to put down the rebellion, declaring "the very firstlings of my heart shall be / the firstlings of my hand" (IV.i.162-63). Not only does he state that he will bring his sword down on a whim, but he implicitly links such shows of manliness to the heart, a symbol of emotion, thereby further divorcing masculinity from reason and aligning it instead with impulse, a traditionally feminine trait.
} 
ultimately weakens his ability to prevent his own demise. Despite the fact that the first

apparition cautions him to "beware MacDuff" (IV.i.85), and he admits that the mention of his rival "hast harped my fear aright" (88), he dismisses the warning in the next moment when the second apparition grants that "none of woman born / Shall harm Macbeth" (94-95). Satisfied with what he hears, he mocks "then...MacDuff—what need I fear of thee?" (96) Accustomed to viewing his circumstances in ways that corroborate his need to feel secure as both man and monarch, Macbeth never considers the possibility that perhaps MacDuff is not of woman born, despite the fact that caesarian sections were known to occur at the time. ${ }^{148}$ Instead, he assumes that the second apparition cancels out the first, regardless of the fact that such was not the case in the first encounter with the Sisters; rather, that all three came to fruition in spite of his doubt. ${ }^{149}$

The problem with his misinterpretation is that it propels Macbeth's belief in his own authority beyond even the Sisters themselves, to the extent that he begins to ally himself, without intermediary, to the powers of Fate. This becomes yet another way he suppresses potential feminizing influences, even as the Sisters represent a gender androgyny which is arguably more balanced and beneficial than Macbeth's own vision of manliness which is entirely free of female influence. ${ }^{150}$ He does this implicitly early on, when he hears the prophecies and immediately

\footnotetext{
${ }^{148}$ According to J.E Sewell and the National History of Medicine, the first recorded caesarian section occurred in England in 1500, by Jacob Nufler who performed it successfully on his wife. The child lived to be seventy-seven and his wife was able to give birth normally afterwards. It was then known as the "caesarian operation", but was renamed "section" in 1598 when Jacques Guillimeau coined the term in his book on midwifery. For more information, see Sewell's "Caesarian section - a brief history. A brochure to accompany an exhibition on the history of Caesarian Section at the National Library of Medicine" and https://www.nlm.nih.gov/exhibition/cesarean/part1.html

${ }^{149}$ When the Weird Sisters hail Macbeth as "Thane of Cawdor", he dismisses it as an impossibility because "the Thane of Cawdor lives" (I.iii.72). Only 30 lines later does Ross appear to confirm that Macbeth has indeed been granted the title of the disgraced lord (105).

${ }^{150}$ Rather than being the vengeance-obsessed, angry hags typically characterized in early modern literature on witchcraft, the Weird Sisters underscore Macbeth's bloodthirsty tyranny which is fueled by his desire to adhere to patriarchal standards of manhood. The Sisters are, thus, not "an inversion of gendered codes but rather a subversion of the symbolic structure that renders these codes possible" (Woods 16). They succeed in subverting contemporary witch-beliefs by revealing that men like Macbeth, who occupy the very heart of the system which orders society, are the true threats to socio-political stability, are the true perversions of ideal male virtu and virtue, which the drive for
} 
concludes that his action is somehow necessary to bring destiny to fruition. He is more explicit in this regard when he plots Banquo's murder: 'Rather than so [Banquo's line of kings], come Fate into the list / And champion me to the utterance" (III.i.70-71) of Banquo's death sentence. Here, Macbeth suggests that his command would voice Fate's intention, as though Banquo's murder is something that Fate itself supports. In this way, Macbeth imagines himself to be a vessel of fate, as though it can only achieve fulfillment through him. He again implies an intimate relationship with destiny when he claims he will take "a bond of fate" (IV.i.97) to kill MacDuff, as though he has the power to negotiate with Fate to serve his own purposes.

However, in so doing, Macbeth creates for himself a false sense of security which guarantees his demise. He errs in underestimating the power of the prophecies, and of the Sisters themselves, when he scoffs at the prospect of Birnam Wood coming to Dunsinan, "who can impress the forest, bid the tree / unfix his earthbound rest?" (IV.i.110-11) Macbeth forgets, that only lines before, he praises the Weird Sisters as, ...you [who] untie the winds, and let them fight Against the churches; though the yeasty waves Confound and swallow navigation up: Though bladed corn be lodged, and trees blown down, Though castles topple on their warders' heads; Though palaces and pyramids do slope Their heads to their foundations (IV.i.65-72).

Because of his hyper-reliance on his own ability to control Fate itself through the exertion of manly violence, Macbeth overlooks the power of the Sisters, who are the true harbingers of Fate and of nature itself. If they can blow down trees, would it not be plausible to assume that they, or the powers of destiny they serve and/or represent, could "bid the tree unfix his earthbound rest?"

authority and security risk overwhelming. Instead, the Weird Sisters establish what Willis calls "completeness through a form of hermaphroditism", humiliating, and implicitly reproaching, their male rivals for their defective masculinity (168). Here, "defective" does not infer weakness, but a hyper-masculinity founded upon bloodshed and usurpation. 
But Macbeth does not consider such possibility, as he does not expend energy to critically consider the warning about MacDuff, because doing so would engender a fear for the sense of security he has tried so desperately to preserve, and, as I have discussed, fear is not something Macbeth actively chooses to confront. Here, his subversion of the feminine, both the feeling of fear-which, as Seth Schein notes actually signifies rational skepticism which he henceforth forsakes - and of the Sisters themselves in disregarding the truth of their prophecies, highlights the link between Macbeth's reliance on his own manliness and the lack of reason ${ }^{151}$ that results from the false sense of security in his ability to assume total control through violent action.

\section{Which Witch is Witch?}

Macbeth's desire for power, which the Weird Sisters expose in their first encounter with him, drives him into a madness which I argue manifests as his obsession with maintaining his position at any cost. Shakespeare's play thus breaks with conventional associations between men and reason, as Macbeth's descent into delusion and madness coincides with the increasingly violent behaviour which characterizes manhood in the drama. More disturbing is the fact that he nonetheless retains his conviction in what he does for the sake of preserving his power-it may not be right or just according to contemporary value systems, but to him he is justified. Such is evident in the way he phrases his reflections on Banquo's murder, whereby he claims, “to gain out peace, have sent to peace" (III.ii.21). But neither of Macbeth's statements ring true, as the appearance of the ghost of Banquo indicates that his friend does not, in fact, rest in peace, and

\footnotetext{
${ }^{151}$ The irrationality that comes to define Macbeth's masculine mania is all the more evident when his violent inclinations surpass even those of his wife who was one of the foremost advocates of the tie between bloodshed and manliness. When she begins to suspect his scheme against Banquo, in an effort to thwart the part of the Sisters' prophecy that challenge his own ambition - another show of taking Fate into his own hands - Lady Macbeth pleads with her husband, "you must leave this" (III.i.38). For Lady Macbeth, it is enough that they have fulfilled the prophecy and risen to the monarchy - any other action becomes excessive. However, for Macbeth, holding his kingship, his power has become intertwined with the state of his manhood, and so to ensure the latter, he must ensure the former is retained at all costs.
} 
Macbeth's harrowed reaction to the visual manifestation of his guilt further denies that he himself feels any peace in the acts he has committed in his quest to secure his kingship. However, by making such statements, Macbeth demonstrates his willingness to manipulate circumstances to suit his needs.

Consequently, he creates a chaotic and violent Scotland which the Sisters then seek to rectify. Rather than proving themselves to be a social disturbance, they act more in service of the larger community than Macbeth himself does when they plot specifically to use his false sense of security against him in order to rid the world of his mad obsession with maintaining power. They claim that by raising "artificial sprites / As by the strength of their illusion / Shall draw him on to his confusion / He shall spurn fate, scorn death and bear / His hopes 'bove wisdom, grace and fear" (III.v.27-31). Cochrum recognizes that here, the witches aim "to remove a tyrant, right a wrong, restore lawful rule" (195). By acting to overthrow Macbeth, the Sisters demonstrate an awareness of the need for objective justice, which Macbeth himself lacks. They, thus, prove themselves to be more rational and strategic than the manly king, whose sole focus rests on protecting his position from those who might seek to take it from him. However, the Sisters also demonstrate cunning enough to secure Macbeth's trust in order to enact his downfall, thereby further exhibiting the kind of rational intelligence conventionally accorded to men.

Just as Macbeth demonstrates how manly conventions can extend one beyond the realm of reason, so, too, do they supersede his moral instincts. Rather than theological ideas of right and wrong, Macbeth puts stock in his own authority as a man, and, consequently, his ability to take charge of even fate itself. He indicates his willingness to forsake his ties to religious morality in the very first act when he pleads, "stars, hide your fires, / Let not light see my black and deep desires" (I.iv.51-52). Asp astutely observes that "for Macbeth, 'being a man' has 
become synonymous with being invulnerable to conscience, fear or compassion" (164), and so he seeks celestial concealment, and by extension, corroboration of his dark desires, rather than looking to the heavens for guidance or forgiveness. This is evident in his self-debate over murdering Duncan, where he expresses a desire to "jump the life to come" (I.vii.7), to avoid the spiritual consequence for what he knows is a moral transgression. Furthermore, his concern is not the immorality of the deed, but the possible divine retribution, the "even-handed justice" (I.vii.10), murder might invite — in addition to the taint the deed will have on his own name should anyone discover him, and so "blow the horrid deed in every eye" (I.vii.24). His moral consideration is overshadowed by a concern for his own status and security. Brian Morris agrees that Macbeth "never exercises his regal power to do anything but preserve his own position" (3839). Indeed, as the play progresses it becomes more evident that Macbeth aims not for glory, or even for praise; he merely strives to hold on to the power he sacrificed his own salvation to obtain.

However, like the fear that continues to threaten his masculine security, the moral instinct that Macbeth seeks to suppress in order to maintain his power is not easily quelled, and this is evident in the moments of remorse that overwhelm him, particularly surrounding the murder of Duncan. After he does the deed, Macbeth expresses genuine distress at his inability to employ divine rhetoric: "But wherefore could I not pronounce ‘Amen'? / I had most need of blessing, and 'Amen' / Stuck in my throat" (II.ii.30-31). Here, it becomes evident to Macbeth that by murdering his king, he has severed his ties to God, and so forsaken the goodness that he himself has removed from the world by disposing of one of His most spiritual agents. The weight of his crime manifests in his assertion that he will "sleep no more" (II.ii.34), as the guilt he feels at killing his king will prevent soundless slumber from that point. However, rather than indulging 
his grief and his guilt, and using it as a means of spiritual and moral redemption, Macbeth chooses to turn away from his action, to bury it within himself as the goal he pursues leaves little space for weakness, of which Duncan himself is proof. He says to his wife, "I'm afraid to think what I have done; / Look on’t again, I dare not" (II.ii.50-51). Here, fear and morality become explicitly entangled, and Macbeth must subvert them both if he is to successfully obtain and hold the throne. As he will not dare to look upon his act, neither by going back to the scene of the crime ${ }^{152}$ nor by thinking more about it, so he declares his hands "pluck out mine eyes" (II.iii.58) — that the actions he undertakes must be done blindly, for to "look on't again" would risk unravelling masculine shows of strength upon which manly success in war and politics depends. And while Macbeth's demonstrations of grief at murdering Duncan gestures towards a potential for moral redemption, his decision to put remorse aside highlights the degree to which his aggressive nature overwhelms his moral one.

Unlike Macbeth's violent suppression of the larger moral order, the Weird Sisters become unexpected vessels for the maintenance of that order. They do exhibit aggression of their own against the sailor and his wife after the wife insults the first Sister, ironically by calling her "witch" and refusing to share her goods (I.iii.4, 6). But it is important to note that in this instance, as in all of the others in the play, their malevolence is less extreme than Macbeth's own. ${ }^{153}$ The Sisters never profess to have killed anyone, unlike Macbeth whose hands are awash

\footnotetext{
${ }^{152}$ Macbeth never returns to Duncan's room; even when he tells MacDuff, "I"ll bring you to him" (II.iii.45), the action implies that Macbeth brings him only to the door, while only MacDuff actually enters to see the body lying dead, and then re-emerges to relay the sight to everyone else.

153 The first Sister claims that she will take her revenge against the wife who offended her by going to the sailor, and "I'll do, I'll do and I'll do" (I.iii.10), which, as Edward H. Thompson suggests, connotes sexual interference (n.p.) in order to humiliate and shame the wife. Additionally, she vows that she will rob the sailor of sleep-which could also be a reference to sexual tenacity - and that he "shall live a man forbid. / .... / Though his bark cannot be lost / Yet it shall be tempest-tossed" $(21,24-25)$. Brooke glosses "forbid" to mean "cursed", ${ }^{153}$ suggesting that the first Sister plans to punish the wife further by cursing her husband, dooming him to a lifetime of tumultuous seas and uneasy travel.
} 
with the blood of his victims. Even the ingredients of their cauldron imply mutilation, but not death, and it is never stated that the Sisters themselves are responsible for wresting the various parts_-"Liver of blaspheming Jew, / ... / Nose of Turk and Tartar's lips; / Finger of birthstrangled babe" (IV.i.26, 29-30) — from their original owners. But Brooke's notes underscore an intriguing pattern among the catalogue of bodies the Sisters list - they are all persons who have transgressed the moral order in some way, and thus, regardless of whether the Sisters had a direct role in it, their mutilation seems just punishment for their offences against God. The "blaspheming Jew" is the "anti-Christian" 154 who insults the Almighty by speaking against the dominant (thereby conceived as the "true") religion. Turks and Tartars were "infidels, notorious for cruelty and sensuality", ${ }^{155}$ both violations against moral decency, and the "birth-strangled babe", presumably unbaptized, was a punishment to all such faithless parents who would doom their child from infancy. ${ }^{156}$ Unlike Macbeth, who undertakes violent action to serve his own desire for security and power, the Sisters' actions, even if unintentional, serve the interests of the larger moral order, which operates on the basis of reward for the righteous and punishment for the sinners. It is ironic, but also telling, that this moral justice should be delivered through the Sisters, who are presumed outsiders to that order, rather than by Macbeth, who as king, should be its purveyor. By confounding their conventional role, the Sisters further underscore the problematic nature of the aggressive values inherent in patriarchal authority, which have imbued Macbeth with a violent desire for power and position, and for which he justifies subverting the moral and emotional tendencies that make a person human.

\footnotetext{
${ }^{154}$ IV.i.n.26 pp. 169

${ }^{155}$ IV.i.n.29, pp. 169

${ }^{156}$ Brooke notes that "as well as being a horrid image, this refers to the idea that unbaptized babes were condemned to Hell" (IV.i.n 30, pp.169).
} 
The more determined Macbeth is to use violence and bloodshed to secure his position as a leader and as a man, the less "man" he becomes. ${ }^{157}$ Instead of developing into "so much more the man" (I.vii.51), it is my contention that Macbeth's tendency towards violence and his lack of moral concern for his reprehensible actions initiates his evolution into a kind of witch-figure ${ }^{158}$ arguably more closely affiliated with the seventeenth-century concept of the maleficent witch than the Weird Sisters themselves. Cochrum observes that like an early modern witch, Macbeth "mak[es] an unholy bargain for power and seeking in unnatural fashion to close the gap between his desire to reign and the actual thing" (184). According to Malcolm Gaskill, even more than the female witch, the male witch's covenant with the devil was marked by with blood ("Kent” 177), and Macbeth himself recognizes, "I am in blood / Stepped so far, that should I wade no more, / Returning were as tedious as go o'er" (III.iv.137-39). Blood has become his primary signifieras king, tyrant, murderer, and man. He is evidently so accustomed to bathing in the blood of his victims that the very act of bloodshed has become tedious. Here, again, he demonstrates a horrifying indifference to his moral atrocities, further revealing that he has forsaken all moral laws in favour of actions which benefit himself and his position. Macbeth, however, does not make his bargain with the witches, who do not demand any action from him at all, but rather serve as messengers of fate in their initial encounter. Nor arguably does he contract with the

\footnotetext{
${ }^{157}$ Asp notes that in the play, "the conviction that valour is the whole of virtue (more like virtus) can displace the values of peace with those of war and cause the metamorphosis of the human into inhuman being" (154); Ramsey likewise observes that the more Macbeth strives for what he considers to be manliness, "the more he perverts that code into a rationale for reflexive aggression - the less humane he becomes" (287).

${ }^{158}$ Anne Louise Fisher makes a similar claim, that the play shows how the Macbeths "essentially become witches...making a man, Macbeth, witch-like" (212); Stephen Greenblatt agrees that he "manages to duplicate them [the Weird Sisters] in a monstrous threat to the fabric of civilized life" ("Bewitched" 34). Rather than duplicate them, I argue that he becomes more conventionally witch-like than the Sisters can be said to be, as he is motivated by the kind of malicious intent and thirst for blood typically thought of the early modern witch, while the Sisters, in their prophetic capacity, are more ambiguously amoral.
} 
devil in the Faustian sense; rather, Macbeth's covenant is with the darkest parts of himself, the devil inside, which he uses the prophecies as an excuse to unleash.

Macbeth further comes to embody the witch in his language, which often reflects the words, tone, and intent of the Weird Sisters. This occurs at the very start of the play, when his “so fair and foul a day I have not seen" (I.iii.38) echoes the Sisters' earlier "fair is foul, and foul is fair" (I.i.11). Richard Ide argues that this initial verbal wordplay indicates "psychological affinity with the diabolical forces... where will is open to the solicitation of the witches" (341). ${ }^{159}$ David Kranz notes the other ways the Sisters' speech patterns appear in Macbeth's own language throughout the play. Just as they tend to speak in alliterative verse, often using multiples of threes, Kranz observes how Macbeth's speech about Duncan's assassination is permeated by similar linguistic elements (346). ${ }^{160}$ Just as these speech patterns echo the linguistic style of the Weird Sisters, so, too, does Macbeth continue to spout the words of the apparitions the Sisters bring forth, as they bring him comfort and reassurance of his own invulnerability in the coming war. The second apparition tells Macbeth that he shall "laugh to scorn / the power of men" (IV.i.93-94); as the drums roll to usher in the battle, Macbeth claims, “our castle's strength / Will laugh a siege to scorn" (V.v.2-3), and when the Young Seward confronts him, he mocks, "But swords I smile at, weapons laugh to scorn" (V.vii.13). The irony of all this laughing and scorning

\footnotetext{
${ }^{159}$ It is also telling that both instances of fair/foul refer to the state of the air; Mary Floyd-Wilson argues that the play suggests Macbeth is susceptible to the very air of the witches. By standing in their presence, his body becomes physically permeable to their influence (150), as though the power of their words literally seeps into his very pores to consume, and transform him. Macbeth himself implies this: "Infected be the air whereon they ride / And damned all those that trust them" (IV.i.153-54).

${ }^{160}$ In I.vii.1-16, , it is evident that alliteration appears throughout the monologue: "'tis... 'twere", "could...consequence...catch", "surcease, success", "be...be-all" etc. Moreover, it is intriguing that in debating about whether to kill Duncan, Macbeth visualizes multiple acts occurring in three stages: (1) "if it were done (2) when 'tis done, then "twere well / (3) it were done quickly"; (1) "we but teach bloody instructions / (2) which being taught, (3) return"- furthermore, even as he claims Duncan is in double trust, Macbeth actually identifies three roles for himself: kinsman, subject, and host.
} 
is that Macbeth fails to see that he himself is among those men whose power one might laugh to scorn — and by displacing himself from the group of earthly men to whom the prophecy refers, he evidently demonstrates an identification with a different entity invulnerable to the powers of men, not unlike the Sisters themselves.

He further takes on this non-human role when he threatens the Sisters with an "eternal curse" should they refuse to answer his queries (IV.i.120). Not only does this demonstrate his overconfidence in his own power, but it suggests that he has appropriated their power as his own. Moreover, his aggressive and vengeful reaction to the possibility of being denied his desire recalls early modern witches, who "for many pamphleteers were vengeful creatures who reacted unnecessarily violently against those whom they perceived to have wronged them" (Millar 88). By reverting to such dire and demonic threats against the Sisters, Macbeth exudes a manly authority that not only exceeds the bounds of what is humane, but imagines itself as a superior and commanding force of even the supernatural — a demonstration of self-assurance in masculine power that becomes more problematic than even the Weird Sisters are. Cochrum notes that by presuming to make demands of the Sisters, Macbeth "smacks of egotism and" — citing C.J Lewis - "the ruthless sleepless, unsmiling concentration upon self which is the mark of Hell" (197), a witch's mark which Macbeth brands upon himself in his quest for manly power.

\section{A Man of his Time}

In the end, the Sisters are allowed to vanish freely, while Macbeth, the pseudo-witch, finds himself "tied...to a stake, I cannot fly" (V.vii.1). The reality of his demise comes to a head here - his focus on power and the reliance on his own masculine authority has transformed him into an unnatural, immoral monster who must burn for his crimes. It is telling that Macbeth holds fast to his belief in the power of violence and aggression until the very end of his life. However, 
part of this persistence comes as a tragic symptom of finally acknowledging the meaninglessness of all of his efforts to hold onto power, which in the end, have "signif[ied] nothing" (V.v.28). The repetition of "tomorrow" (19) in his infamous final monologue encapsulates the unending monotony of the cycle in which Macbeth has found himself - a cycle of violence for power and position, from boyhood to manhood, ${ }^{161}$ between life and death as one man replaces another at the top of the patriarchal hierarchy. Intriguingly, his reiteration of "tomorrow" also occurs thrice, which suggests that the Sisters' influence, whose use of verbal triples Macbeth reflects in his own speech, extends into, and indeed, effects this realization that the manhood he has ruthlessly pursued has resulted only in emptiness and destruction. At the end, he knows that "honour, love, obedience, troops of friends / I must not look to have" (V.iii.25-26), as his desire to prove his manhood through acquiring power has supplanted all other values, particularly those that might have saved him. Instead, he looks to the same masculine code of violence he himself has kept to be his undoing, insisting "I'll fight, till from my bones my flesh be hacked" (V.iii.31)—which further implies that the cycle will inevitably continue even after his death.

But several scholars have suggested that at the end of the play, MacDuff's victory foretells positive futurity because he represents the kind of internal balance between reason and emotion, masculine and feminine that Macbeth evidently lacks. Adelman claims that "MacDuff becomes the example of a healthy manhood that can include the possibility of a relationship to women" (48). ${ }^{162}$ Indeed, MacDuff proves himself a foil to Macbeth, particularly in his ability to reconcile manhood with human feeling; his response to his family's murder-“I

\footnotetext{
161 To contrast his own manliness and so assert his authority, Macbeth refers to Malcolm as "the boy", "lily-livered boy" (V.iii.3, 15). Yet, that implicitly positions Malcolm in the cycle of patriarchy as the boy will inevitably become a man who will be indoctrinated into the same ideas of manhood which produced Macbeth.

162 Similarly, Asp argues that MacDuff portrays "a complete human being that can integrate both feminine and masculine response" (155), and Kimbrough writes that "through MacDuff, Shakespeare shows bravery and compassion are not incompatible; they are both normal, human attributes" (178).
} 
must also feel it like a man" (IV.iii.221)—highlights the coldness of Macbeth's apparent stoic indifference to hearing of his own wife's death. ${ }^{163}$ However, the ending of the play nonetheless suggests that even MacDuff is part of the same masculine system of violence and power that motivated Macbeth's ambition. Willis notes that the all-male restoration in the final scene still "depends on the violent exclusion of other males" (213), which is further evident in the fact that the primary image associated with MacDuff's victory is the bloody head of his rival atop a spike. ${ }^{164}$ Asp, too, observes that because the conclusion mirrors the start, both marked by the war against and triumph over a traitor against the crown, the play suggests "society's continued acceptance of the values and stereotypes that paradoxically both threaten and guarantee its continuation" (168). The threat which such masculine violence poses again harkens back to the anxiety that is inevitably inherent within a system that operates on the exchange of power through aggressive means. Accordingly, the Weird Sisters do not reveal social anxieties around women $^{165}$ so much as the problematic nature of the patriarchal world which, by its very ideals, creates the monsters that it can then ostracize and point to as other. The Sisters, thus, are not the ones society should fear — unlike the old hag in Darrel's pamphlet, who seeks the physical harm of her victims and, indeed, influences them to harm themselves. But Macbeth's actions are more severe than even those of Darrel's hag because in addition to denigrating his own mental state, his ruthless bloodthirst has horrific consequences for the people around him, and the very people

\footnotetext{
${ }^{163}$ When the doctor tells Macbeth that Lady Macbeth has passed, he simply states "she should have died hereafter" (V.v.17), before launching into his "tomorrow and tomorrow" monologue. Arguably, his speech on the meaninglessness of life in view of the ever looming destruction of death could be interpreted as an ode to the grief he feels for a life without his wife, but his stoic delivery contrasts sharply with MacDuff's own impassioned response.

${ }^{164}$ Willis further observes that while the play might want to emphasize the restoration of patriarchal rule at the end, "it also makes painfully clear that a truly restorative alternative... is not forthcoming" especially as Malcolm's healing takes a military form (235-36).

165 As scholars like Katherine Woods (p. 185) and Heidi Breuer (p. 122) suggest is one of the Sister's primary functions.
} 
he was supposed to rule and serve. Thus, while the pamphlet reiterates narratives of the evils of witchcraft and the plights of men unlucky enough to encounter it, Shakespeare's Sisters “expose a reverence for a hierarchical social order for what it is, as the pious self-deception for a society based on routine oppression and incessant warfare" (Eagleton qtd. in Cochrum 195-96). In seventeenth-century England, it was common for people to accuse others of witchcraft in an attempt to conceal their own social guilt (Macfarlane 196). Shakespeare uses his Weird Sisters to expose the high stakes of this practice, particularly when the most senior ranks of the social order seek to conceal, rather than rectify, their own problematic ideologies. The result is that the violence and aggression which characterize power in these patriarchal structures continue to be proliferated, rather than admonished. Thus, despite the trail of blood he leaves behind him, the audience might nonetheless feel sympathy for Macbeth even at the end of the play_for, as Karin Coddon observes, he becomes "the effect of a disorder that manifestly precedes... and produces him" (48).

\section{$\underline{4.5 \text { Canidia }}$}

Darrel's tale of William Somers does not end after his interrogation in October 1597. ${ }^{166}$ It continues into November of the same year, where ministers and civil servants who knew Somers became concerned that he was possessed. As proof, one minister relayed, "this evening [November 5] he acted many sinnes... as namlye brauling, quarrling, fighting, swaring, robbing...whordom....hyporcise....also he laughted exceedingle, divers times clapping his hands on his thighs for ioye". The minister moved to exercise him; yet, the same night he was thought to be "dispossessed... as he lay in bed, a thing like a rat parted one his mouth and after crept doune along on his bodu until it came to his privye parts, from whence it vanished away".

\footnotetext{
${ }^{166}$ Continued from prior pamphlet, cited at the start of Macbeth section.
} 
Darrel further relays that between March and November, several of Somers' neighbours came forward with accusations of witchcraft against him. One such accusation alleged "that upon such a day in Nott[ingham] market, Som[ers] should trede on the hele of....[M] Sterland whereupon he should presently fall sicke and dyed 4 or 5 days after. The neighbours, they witnessed, that Sterland, being dead, his heele looked blacke". The magistrates then "tooke this witch... and committed him to their house of correction". However, even when he seemed to be “dispossessed", as noted above, he was again accused by seventeen locals, "every of which deposed more or less to som thing don or suffered by So[mers] which neyther natur not art can compouse". Somers was again detained by the magistrates, during which time he was "thruste deepe into the hand \& leg with pins, but stirred not...neyther did any of the blood issue at any of the places so pricked". In response to this interrogation and torture, Somers claimed that John Darrel — the very author of the pamphlet — had taught him to feign such witchlike behaviour. However, Darrel vehemently refutes the accusation and ends the pamphlet with his own defense of the situation; thus, it remains unclear at the end whether indeed Somers was faking, or whether his behaviour could be said to truly be the work of the devil.

Rather than choose to examine two distinct pamphlets as I have done in the previous chapters, I have decided to focus on Darrel's pamphlet alone in both of my dramatic analyses because of the fascinating turn Somers' journey takes. His trajectory echoes that of Macbeth and Thomas Goffe's Orestes (as I will demonstrate in the following analysis), both of whom start as participants in supernatural encounters with witches, only to transform into pseudo-witches themselves. In Somers' case, that transformation seems rather more literal than merely behavioural, as there are numerous subtleties in Darrel's retelling which parallel Somers with the conventional early modern witch. His initial disturbing behaviour closely reflects the disruptive 
actions ascribed to witches; Macfarlane notes how witchcraft in the seventeenth century was specifically linked to quarrelling, and many witches were accused of being scolds $(158,170){ }^{167}$ The reference to "whordom" harkens back to the intense sexuality associated with witches, being "lustful [and] leading a lewd life" (Macfarlane 158), and Thomas Cooper states that sexual intercourse with the devil was common among a witch's most deplorable behaviours (92). Moreover, the appearance of the rat and its intimate physical connection with Somers recalls the witch's familiar, a devilish spirit in animal form which assisted the witch in his/her misdeeds. It was common for the familiar to have such literal physical attachments to its witch, as the rat seems to vanish into the private regions of Somers' body; in her trial examination, Elizabeth Stole admitted that her rat familiar would feed off blood from her right wrist (Gibson 35). The rat's association with the genitals in Darrel's pamphlet further recalls the idea of the witch's sexual affiliation with the devil. Additionally, Somers' non-reaction to being pricked with pins is suggestive of the witch's mark, a gift from the devil which, as Alexander Roberts writes, "remaineth ful of paine and anguish until his returne againe: at which time hee doth so benume the same, that though it be pierced with any sharpe instrument, yet is without any sense of feeling, and will not yield one droppe of blood at all" (15).

But despite the surprising arc of Somers' story, the conclusion of the pamphlet is underwhelming for several reasons. First, Darrel explicitly demonstrates his author bias when he abandons arguably the most captivating parts of the story in order to take himself out of the narrative (though by doing so, he ironically inserts himself in it all the more). Second, Darrel's privileging of his own defense leaves Somers' tale quite incomplete, as there are several questions left unanswered. What happened to the accused? Was he examined, tried, hanged?

\footnotetext{
${ }^{167}$ In his Discourse on Witchcraft, Perkins includes "quarrelling or threatening" among likely characteristic identifiers of a witch (202).
} 
Indeed, his initial punishment, being sent to the magisterial "house of correction," seems lenient for a crime that might have been severely punished, particularly on the threshold of the sixteenth and seventeenth centuries. ${ }^{168}$ Why should Somers escape justice when others died under similar circumstances? Whether or not this speaks to the gender bias in witchcraft trials and executions is an investigation I do not intend to undertake here, but it is my aim to demonstrate that where Darrel's pamphlet fails to consider the psychological, moral and social consequences of Somers' witch transformation, Goffe's Tragedy of Orestes, like Macbeth, succeeds. I will note here that in the following analysis, I will be intermittently comparing Goffe's Orestes to the classical Greek Aeschylus's Orestes in the Oresteia, who takes revenge against his mother in The Libation Bearers. Intriguingly, Aeschylus' version of the tale does not include a witch, which seems to be Goffe's addition, and so by comparing the two versions I hope to emphasize the role that Canidia plays in facilitating a psychological journey that forces Orestes to engage with the problematic values of violence and extreme aggression inherent in codes of inheritance and filial expectation which dominated Goffe's time.

\section{Another Filial Avenger}

Like Antonio and Hamlet, for much of Goffe's play Orestes' thoughts and actions are consumed by thoughts of revenge for his murdered father-a sign that he, too, is invested in the filial obligation inherent in patriarchal inheritance, which I discussed at length in the first chapter. The very start of the play foreshadows the gumption with which Orestes will later take up his role as filial avenger when, anticipating his father's return from war, Orestes proclaims, "my empty soule is now fild to the top / Brimfull with gladnesse" as "In this brest... / ... / Ten

\footnotetext{
${ }^{168}$ Brian Levack notes that in Essex county alone between 1560 and 1672, 291 people were indicted for witchcraft, though only 74 were executed (24\%) (Sourcebook, 23). However, Malcolm Gaskill notes that between 1560 and 1600 in England as a whole, 258 people were indicted while only 59 were executed ("Evidence", 40). Taken together, the statistics suggest that the vast majority of executions took place at the tail-end of the sixteenth-century.
} 
clumsie winters and ten lagging springs / Hath with my Fathers absence frozen beene / All thoughts of joy which now shall make a spring" (I.iii.2-3, 15-19). It becomes evident early on that Orestes' close relationship with his father will produce an eager revenger more akin to the overzealous Antonio than the more explicitly burdened Hamlet. His language also reflects the immense passion that comes to characterize Goffe's Orestes, unlike Aeschylus' more classically stoic Greek protagonist. It is this passion that Goffe's Orestes struggles to contain throughout the play since, as in the case of Macbeth, he deems such outward shows of emotion effeminizing and weak, and so they must be dispelled if one is to prove man enough to fulfill his filial duty. Such is evident when Orestes discovers that his father has been murdered, and he consciously acknowledges the need to subvert his passions in favour of the emotional indifference which will allow him to pursue revenge: "O I rave out / My passions; doe grieve, poure out thy selfe / that thou mayst make roome in my empty heart / To fill it with revenge" (I.v.49-52). By declaring that he will empty his heart of his passions in order to make room for revenge, Orestes implies that there cannot be space for both—emotion would only impede his vengeance, and so make fulfilling his filial obligation impossible. The negative correlation also segregates filial duty specifically from feminine shows of passion, and so to be the masculine son, Orestes must forsake the more effeminate parts of himself, just as Macbeth did. Comparably, the reaction of Aeschylus' Orestes to his father's death is sorrowful without being overly passionate, as he laments, "I was not by, my father, to mourn for your death" (9). Aeschylus' Orestes expresses regret at his inability to mourn at his father's gravesite, having been in exile—-for him, fulfilling his duty as a son and being allowed to grieve for his father are inextricably entwined, unlike Goffe's Orestes, who seeks to suppress such emotion so that he might fulfill what early modern convention calls a son to do in the wake of a father's murder. 
However, as the play progresses, Orestes struggles with containing his passionate nature, despite making claims like "passion [has] left the heart" (II.ii.113). Instead, his eagerness for bloody revenge creates a link in the play between filial obligation, and excessive emotion which would otherwise be associated with womanly inferiority. In so doing, I argue that the play aligns traits generally associated with gender weakness with acts like filial revenge-representative of the endless cycle of violence and expectation patriarchy confers on its participants. I believe by suggesting this link, the play implicitly challenges the validity of certain patrilineal practices, which are used to prescribe good sons and worthy future patriarchs. When strategizing how best to take his vengeance, Orestes demonstrates a rashness not unlike Macbeth's claim to honour the firstlings of his heart with his hand: "Why should I not now drove my vengeful sword / And strait'way sheath it in murderer's heart?... / Well I will goe, and so massacre him" (III.ii.23-24, 27). Orestes' use of the word "massacre" as opposed to "kill" or "end" reflects his extreme desire for violence against those who took his father from him. A massacre connotes a killing spree, ${ }^{169}$ yet to use it in terms of one person emphasizes further the excessive, passionate zeal with which Orestes seeks vengeance. And rather than worry for the state of his soul or mind as Hamlet does when he wrestles with killing his uncle, Orestes claims that only this degree of aggression can possibly put his uneasiness to rest: "O how two'ld ease / My heart to see a channel of his blood / streaming from hence to hell, that killd my father" (III.ii.62-64). For Orestes, the spilling of blood signifies the fulfillment of his oath to his father, and yet the enthusiasm which drives him to seek not merely blood spilled, but a "stream" of blood, again harkens back to the extreme

\footnotetext{
169 According to the Oxford English Dictionary, the common definition of "massacre", used since the late 1580s, is "To kill (people or, less commonly, animals) in numbers" (OED, emphasis mine).
} 
violence that seems to be required (or, at least, which Orestes believes is required) in order for him to adequately perform his revenge task.

\section{A Man of Action}

In both Macbeth and Orestes, then, blood will have blood (Miola 151). But the desire for bloody revenge that Goffe's Orestes displays veers from Aeschylus' Orestes, who questions, "what can wash off the blood once spilled upon the grave?" (48) The ancient Orestes knows that revenge, as emotionally cathartic as it might be, cannot bring back the dead, and so here he challenges the value of the revenge cycle which, practically, achieves very little. Goffe's Orestes, however, makes no such rational, skeptical considerations, as he persists in his quest for the blood of those who murdered his father, as though their murder could somehow physically and spiritually cleanse the corpse of the dead Agamemnon. He declares, "I will bedew / Thy hearse with blood instead of brinish tears / And build up a pile of their murdered truncks / To burn thy marrow" (IV.vii.54-57). Here, Orestes echoes Antonio's action, wherein he nourishes the hearse of his dead father with the blood of the murdered Julio as a means of setting Andrugio's ghost on the path to rest. He again demonstrates his determination to subvert emotion, "brinish tears," with manly action by spilling the blood of his enemies, and using their bodies as a pyre upon which to display, and honour, his dead father. However, while the idea of "burning thy marrow" connotes both a traditional Greek warrior's cremation and a spiritual cleansing whereby body and soul are purified by fire, the reality is that Agamemnon's body has already been buried, and his marrow, along with the rest of his flesh, has disintegrated to the point that only his bones remain. ${ }^{170}$ Orestes' blood offering, then, cannot achieve the kind of physical or spiritual effects to which his words aspire; instead, Orestes' promise to his dead father signifies his own internal

\footnotetext{
${ }^{170}$ This is apparent in the play when Orestes has to dig up his father's bones to bring to Canidia, which implies that his bones were all that remained in the earth (III.iv).
} 
desire for bloody vengeance as way to honour him, if not upon a physical pyre then at least symbolically, according to the larger patrilineal value system.

It becomes evident that one of the primary differences between Aeschylus' and Goffe's Orestes is their attitudes towards pursuing revenge. Aeschylus' Orestes is more reserved, expressing his grief not foremost at the murder of his father-a crime which necessitates vengeance, though he questions even what such reciprocal action can accomplish—but at his inability to be by his deathbed and at his grave site. Goffe's Orestes, however, demonstrates an automatic inclination towards action, as he seeks a human sheath for his sword, and seeks blood to pay for blood. His insistence on acting is such that to remain idle, even in death, becomes weakness; he implies this when, speaking at his father's remains, he chides the "cowardly bones" (III.iv.29) for allowing themselves to be mutilated by worms and other scavenging vermin. To allow oneself to become prey, to wait to be consumed by another, is to disgrace the manly fortitude that characterizes noble men, and so it becomes Orestes' boon to engage in the active pursuit of revenge - to do otherwise is to resign oneself to becoming (like) the idle dead. Indeed, Orestes imagines his vengeance to be a Herculean task, as he declares not the "fire-breathing bull” Taurus, nor the Hydra nor ten lions will stop him (III.vi.63-65). ${ }^{171}$ However, his reference to Hercules' labours is telling in terms of his overall dismissal of the gods and their power to effect change. Herein lies another substantial difference between the Aeschylean and Goffean Orestes. The classical version caters to its contemporary climate by emphasizing Orestes' reliance on the will and influence of the gods, as he looks to them to both sanction and guide his vengeance: "Zeus, Zeus, grant me vengeance for my father's / murder. Stand and fight beside me" (17-18). Goffe's Orestes makes no such plea. Instead, by implicitly comparing himself to

\footnotetext{
${ }^{171}$ Hydra, lions are two examples of Hercules' mythically "labours" (http://www.perseus.tufts.edu/Herakles/labors.html).
} 
Hercules, and insisting, "I'll be above all fatall power," denying that any "scowling frowne of angry fortune e'er should throw me down" (I.iii.42, 46-47), he imagines himself to be equal to

the gods, and so able to enact and sanction his own revenge (not unlike Macbeth framing himself as a vessel of Fate on level with, and even superior to, the Weird Sisters). But unlike Macbeth, who begins by revering the Sisters' prophecies and eventually takes on the role of Fate-maker himself, Orestes gradually defers his own power to that of Canidia, who comes to signify the godly for him because she, as the Sisters do for Macbeth, gives him what he most desires: confirmation of his suspicions against Aegisthus and Clytaemestra, and so justification to pursue revenge against them (III.vi.35-36).

\section{A Witch to Believe in}

What makes Orestes' deference to and, indeed, worship of Canidia so disturbing is the fact that unlike the Sisters, who are anchored in ambiguity, Canidia appears more like a conventional early modern witch: a threatening figure whose dark deeds demand that she be hunted and eradicated. Katherine Woods notes that "unlike the witches in plays from the Elizabethan period, Canidia is a horrifying witch with potent magical powers" (77). In the play, Pylades describes her as "an old woman... /... / In whose rough face time has now made such holes / ...great in Magique spells / At whose dire voice, the gods themselves would quake / ... / And in the ayre hath flying ministers / To bring her news from earth, from sea, from hell (III.ii.96, 98, 100-104). She, following the typical witch trope, is an old woman who commands sinister-sounding familiars, the "flying ministers" from which she receives information pertinent to her craft. What makes her particularly powerful and frightening is her ability "to command the gods to unlocke the gates of Heaven / And fetch forth death" (III.v.29-30). Here, again, Canidia appears to straddle the mortal and immortal worlds. Her face, in which "time has now made such 
holes" highlights her physical decay to the extent that she appears almost like one of the dead she might summon. But her ability to "command" the gods, to make them "quake" and, indeed, "fetch forth" the dead for her, elevates her above them in power and fearfulness. And Orestes comes to regard her as such, a godly figure to whom he looks for guidance- "show me Canidia where / which way they [the murderers] went" (III.vi.58-59) — and substitutes for the godly reverence which Aeschylus' Orestes gives to the classical Greek pantheon.

Goffe's Orestes yields to Canidia much like Macbeth does to the Sisters in the first act, as he approaches her with more humility than he shows with the gods whose "fatall power" he mocks. When Pylades brings him to her abode to ascertain the truth of his father's murder, Orestes says, "I not command but my astonisht soule / entreats to know" (III.v.26-27). He insists that he does not command, indeed he cannot, which demonstrates a shift in his previous attitude whereby he is the Hercules sent to avenge his father's death. Now, Canidia becomes the one worthy of "astonishment", a kind of spiritual awe conventionally reserved for striking authoritative presences. He also calls her "great prophetesse" (III.v.38), which is intriguing not only because it links her to the Weird Sisters in their prophetic role, but also because unlike the Sisters, Canidia is explicitly referred to in the play's dramatis personae as "witch"- to praise her as a prophet diminishes the evil associated with her given label, and replaces it with a more ambiguous function by making her a tool of fate. Instead of deception, as a minion of the devil, the ultimate deceiver, the "witch" then becomes a truth-teller, upon whose words Orestes comes to rely to sanction his revenge. And like Macbeth's willingness to yield to the Sisters, Orestes reveals his hyper susceptibility to Canidia's influence when he elevates her function beyond even the ambiguous classical fury and into the realm of the godly. He calls her cell "hallowed" (III.v.36) and refers to her as "divine Canidia" (IV.viii.197). However, he nonetheless recognizes 
her "blessed powers of hell" and asks her to "make the dark powers ready at command" (III.vi.73). This is significant because it demonstrates that Orestes is aware that Canidia is a witch, that her powers are dark and are rooted in hellish forces, and yet he chooses to elevate her to the status of the godly; thus he makes a conscious decision to pursue the darkness, both her power and his own internal darkness, in order to fulfill his role as filial avenger. For him, the witch becomes synonymous with the kind of active agent required to achieve vengeance, whereas he scolds "coward Fate" (III.vi.92) that did nothing to intervene, and so prevent, his father's wrongful death. Like the idle bones that can do nothing, so fate is similarly cowardly, and Orestes seeks to set himself apart from it (and, consequently, differentiates himself from Aeschylus' fate-reliant Orestes) by looking to take violent, excessive revenge against his mother and her lover.

Making a Man-Witch

However, as is the case with Macbeth, the more invested Orestes is in acting on the "truth" the witch delivers, the more witch-like he becomes. Woods observes that by handing his father's bones to her, Orestes "places authority over identity in the hands of the witch" (125) — it is my contention that his identity morphs with the witch whose influences comes to guide his actions. This is particularly where Orestes relates to William Somers, whose initial encounter with the old hag engenders a psychological change in the form of violent fits, which seems to influence his own turn towards witch-like behaviour. Orestes, too, undergoes a psychological shift after his encounter with Canidia, whereby his pre-existing desire for extreme revenge becomes exacerbated to mass violence under the influence of the witch and the hell-forces with which she is affiliated. When Pylades cautions Orestes against killing his mother as "the law of nature doth forbid such thoughts," Orestes responds "Nor Gods nor nature should keep me in 
awe" (III.vi.112-113). This points both to Orestes' reliance on the power of the witch over traditional divinity — as when he previously claimed that Canidia "astonisht" him in a way that, evidently, the classical gods cannot — and to the way he harnesses her influence to augment his own conviction in the righteousness of his quest for vengeance. His dismissal of conventional morality figures contrasts sharply with Aeschylus' Orestes, who keeps the gods at the forefront of his action. He claims that Apollo "charged me to win through this hazard / with divination of much, and speech articulate / warning of chill disaster under my warm heart / were I to fail against my father's murderers" (270-73). His words frame revenge as divinely sanctioned, as it is Apollo himself who "charges" Orestes to avenge Agamemnon, and to fail in this mission would warrant his own death - such is the justice of the gods. This also makes taking revenge foremost a matter of self, rather than patrilineal, preservation, so Orestes seems more justified in seeking vengeance if only to guarantee his own survival.

The kill-or-be-killed mentality of the classical Orestes underscores the excess bloodshed which characterizes Goffe's Orestes in his determination for vengeance. He begins by killing the watchman, Misander, without hesitation or second thought because he recognizes Orestes beneath the disguise meant to fool Clytaemestra and Aegisthus (IV.ii.91). He then proceeds to plot the murder of their child. Despite his prior insistence that such an act, which Canidia suggests, would be "too little" (III.vi.124, 126, 128) for what the murderous pair deserves, his decision to pursue this course further underscores the influence the witch has over his psyche. He ignores all those who plead with him to spare the innocent, even verbally toying with Electra when he tells her, "it should have no hurt, worse than my Father" (IV.v.256-57). The pause in the middle of the line suggests an intentional misdirection, where he begins by conceding to her request not to harm the child, but finishes the statement not only by revealing his true intention, 
but by reminding Electra of their murdered father who, in her defense of Clytaemestra's bastard, she seems to forsake. Orestes declares his intention with striking indifference, as when Pylades, too, begs mercy for the child, Orestes demonstrates the degree to which his perception and rationality have been skewed by his obsession with vengeance. He claims that his mother's crime is "transcendent" and if the child "wert not my mothers, I coulde weepe" but "now to shew piety were Impiety" (IV.vii.4, 26, 29). Like Antonio's lament that if he could, he would only kill the parts of Julio which were "father all", so Orestes implies that because the child belongs to Clytaemestra, thus her crime stains him as well, and so he cannot be innocent in the matter because of the moral taint of the woman who bore him (though this ironically implicates Orestes, too- a fact which he ignores, thereby further demonstrating his selective perspective). We get yet another explicit reversal of conventional morality when he claims that traditional piety cannot stand in the case of filial revenge, as it is an exception where piety and mercy do not signify benevolence, but only the weakness of inaction which patriarchal codes disavow. It becomes evident that his focus on revenge, and the filial obligation he uses to justify this action, desensitizes him not only to his own humanity, but to others'. When he stabs the child, he says "this dies" (IV.viii.96); by using the objective "this" rather than the personal referent "he," Orestes detaches himself from the horror of his crime in making the child a mere object. This rhetorical move further demonstrates his evolution into a witch-like figure, as early modern witches were often accused of killing children (Gifford, Dialogue 7).

As Robert Miola notes, in Goffe's version of the play “there could be no success like excess" (147); Orestes suggests as much when he declares, "But who revengeth, must all...exceed" (IV.viii.133). ${ }^{172}$ Here, Orestes again implicitly moralizes his excessive violence by

\footnotetext{
172 This is reminiscent of the Ghost of Andrugio in Marston's play, whose Latin invocation to Antonio proclaims that true revenge must exceed the original crime.
} 
citing his filial duty as avenger of his murdered father-violence and vengeance must, therefore, go hand in hand if one is to fulfill the patriarchy's criteria for good and honourable sons. Even as Pylades rationalizes that one fatal wound will be enough to kill Agamemnon's murderers and so get justice for him, Orestes insists, "All of those wounds will / sticke in his [Aegisthus'] brest", and "she [Clytaemestra] should have more" (IV.viii.88, 90). It is not enough to merely kill Clytaemestra and Aegisthus; he must obliterate them. He justifies this overkill by measuring the worth of their lives against that of his noble father, deciding that "one deaths too little to revenge a king" (IV.viii.165), thus implying that his excessive violence is required and fitting for a man such as his father was - to do less would be to dishonour him, and to deny him the vengeance he deserves. His insistence on hyper-violence seems erratic and frenzied compared to Aeschylus' Orestes, who kills with distinct and specific purpose: "My purpose is to kill you [Clyt.] over his [Aeg.] body / You thought him bigger than my father while he lives / Die then and sleep beside him" (904-06). The classical Orestes is strategic in planning his mother's death, and he plots a revenge that is appropriately measured according to the crime she herself committed. He indicates the same of Aegisthus, who "had his seducer's punishment, no more than law" (990). Unlike Goffe's Orestes, who explicitly denies the rule of law, Aeschylus shows temperance and reason ${ }^{173}$ by keeping his revenge within the bounds prescribed by gods and men — restrictions by which Goffe's Orestes does not abide.

Orestes' transgression of acceptable social and moral boundaries is made explicit near the end of Goffe's play, when the authoritative Tyndarus confronts Orestes about his several murders. He, like Pylades, affirms that one death would have been sufficient to balance his

\footnotetext{
${ }^{173}$ In the "Libation Bearers", revenge becomes a fair fight, still imbued in male violence but a more temperate and necessary kind: "war strength shall collide with war strength; right with right" (261). "Right with right" indicates a kind of equality, even kinship between foes, and the connotation of the word (as in "entitlement") further elicits the idea that Orestes is objectively justified in pursuing revenge.
} 
father's own. However, when Tyndarus warns that the extra murders demand recompense and Orestes' own life might be the price, Orestes merely jeers, "I had three lives, you but my one shall have" (V.i.94). As in his previous measurement of his father's life against those of the murderers, here Orestes quantifies life in terms of sport or competition, further demonstrating his emotional detachment from the very concept of human existence. Nor does he express remorse for his actions; instead, he feels pride in what he views as accomplishments: "this night who would conceale? / Now soule triumph, whilst that my deeds shall shine / I'th'face o'th'Courts" (IV.viii.202-204). ${ }^{174}$ It is a common trope in early modern drama for dark deeds to be performed under the cover of black night—indeed, Macbeth makes use of it during the murder of Duncanbut here, Orestes severs his deed from such need for concealment, thereby indicating that he has nothing to hide, nothing for which to be ashamed. This is reminiscent of Somers' inappropriate laughing fits - unwarranted and ill-timed responses which hint not only at a kind of madness, but also serves as evidence for his witchcraft. Here, too, Orestes' lack of moral concern for his own heinous action and the way he mocks the laws of justice, which are supposed to provide rational order, suggests that his filial obligation to avenge his father has caused him to dissociate action from reason—indeed, his perspective begins to mirror the immoral and lawless chaos often associated with witchcraft. His indifference to traditional moral views is further evident when he declares "soule triumph"; rather than perceive the murders of his mother and her lover as spiritual taint, he considers them spiritual victories, as though they serve a larger purpose than

\footnotetext{
${ }^{174}$ During his brief descent into madness, Orestes has a moment where he considers the situation in a softer, almost child-like tone, when he inquires, "Mother, why mother will you kill my father?" His question rings like a confused child genuinely trying to understand, not necessarily angry, and even perhaps affectionate still towards his mother. However, the rest of the scene is riddled with Orestes declaring his violent intentions towards his mother- "Could I but get the stone from Sisyphus / I'de dash thy braines out"...'I'll stab you lustfull soules with your own knives" (V.iv.31-32, 35) — even as he feels tormented by devils and snakes (19-20), images which could be taken as interior pangs of guilt, though Orestes never openly admits to any.
} 
his own. But, Orestes has divorced his soul from the traditional gods in favour of serving and worshipping Canidia, in which case his murders would be considered victorious indeed, particularly to the woman who influenced his decision to supersede singular revenge by also killing an innocent child. This influence is all the more apparent when, following Clytaemnestra's confession to murdering Agamemnon, Orestes proclaims “O blessed powers of hell, divine Canidia” (IV.viii.197). Here, Orestes praises Canidia for proving trustworthy and reliable in directing him truly towards his father's murderers, rather than deceiving him, as the devil and his minions (i.e. witches) were known to do. His reiteration of Canidia's divinity further implies that as he has found truth and credibility in the words of the witch, so he solidifies his moral allegiance to her and the darkness she inspires in himself. Moreover, making such a proclamation immediately following the mass atrocities he has performed also links the violence he undertakes in his filial revenge to the cruelty and maleficum of the witch herself, thereby aligning this particular expectation of paternal inheritance and dynastic honour with witchcraft.

This association is all the more problematic when Orestes implies that his extreme aggression would not only be sanctioned, but glorified by the highest ranks of society, claiming his deeds will “shine / I'th' face o'th'Courts". The court is arguably the embodiment of patrilineal values, a place where one earns his place on account of family name and social network - the very embodiment of the codes of lineality and family honour which Orestes adheres to by taking revenge against those who have wronged his father and, by extension, his whole family. By claiming that even his excessively aggressive action would be acceptable by members of the court, Orestes highlights the systematic violence inherent in patrilineal values, to the extent that what might seem heinous and immoral to some could be met without much opposition. Orestes 
ties his action not only to courtly expectation, but also to masculine ideals when he claims "how bravely I reveng'd my fathers death / ... Tis my glory / I shall be matter for so brave a story" (V.i.77-79). As in the captain's description of Macbeth, Orestes synonymizes his brazen violence with brave action, which, thus, also connects masculine ideals like bravery to the need for bloodshed. Orestes' proud response to his violence starkly contrasts with that of Aeschylus' Orestes, who, though he has obtained his vengeance, recognizes the crime which he himself has committed in order to do so. He says, "I have won; but my victory is polluted and has no pride" (1017). Guided by the gods throughout his mission, Aeschylus' hero retains his sense of morality; he acknowledges the necessity of his action to honour his father, but takes no pride in the action itself. Goffe's Orestes, having dismissed the gods and transferred his divine reverence onto Canidia, likewise adopts many of her characteristics as he pursues his vengeance, evident in the extreme, unremorseful violence he chooses in that course.

\section{A Real Hothead}

Goffe, whether intentionally or not, draws an intriguing connection between Orestes' violent tendencies and heat imagery, which implicitly links his internal aggression and witch-like transformation. As with Macbeth, whose encounter with the Weird Sisters seems to confirm and augment pre-existing ambition, Agamemnon's death awakens a dormant fire-fury within Orestes, which his interaction with Canidia, and her subsequent influence on him, then exacerbates. After having a dream vision of his father's murder, Orestes insists he must see his father; en route, he, like Macbeth, seems to be guided by a phantom image. However, instead of a dagger, Orestes uncertainly questions, “is this a torch?” (I.v.14) Thus, the first heat/fire image occurs just as

Orestes is about to discover his father's murder and realize his duty to revenge; the appearance of the phantom torch signifies the stirring fire in Orestes' interior, which his desires for more 
violent bloodshed will continue to fan as the play progresses. His speech which precedes his meeting with Canidia (immediately following Pylades' description of her) further foreshadows the hellish affect the witch will have on his psyche as he becomes more and more consumed by his own internal fire in his need for bloody vengeance. This speech also denotes the second time Goffe employs heat imagery, following the phantom torch, and the intensity of the images, both in number and content, reflects Orestes' growing unrest in pursuing revenge, which drives him to seek out Canidia. He says:

Their iterated sight will burne my soule With such a sparkling flame of dire reuenge, As Nessus shirt did burn great Hercules, If that the scrowle which did containe their names, Were in a lake of flaming brimstone drencht, I'd take it out, or fetch't from Pluto's armes:

But come; I fea th haue such a creature as can tell, Twill saue a iourney for this once from hell (III.ii.128-35)

The sight to which Orestes refers here is the name of his father's murderer(s), which he seeks Canidia to confirm. The idea that the revelation of their identities will "burne" his soul suggests not only that Canidia's affirmation will fuel Orestes' internal fire, the "sparkling flame of dire revenge", but that what follows afterwards will, indeed, condemn his soul to burn, tormented in Hades. This implication further resonates in the lines that follow, as he again compares himself and his revenge task to the mythical Hercules when he aligns his own burning —also connoting the suffering at the hands of another-to Hercules' poisoning by Nessus' shirt. However, it is intriguing that Orestes would compare himself to Hercules in this instance, as not only did Hercules die from the poison, but it was Nessus' blood on the shirt, and not the garment itself, which was Hercules' undoing. ${ }^{175}$ By pursuing the spark of revenge, which the interaction with Canidia, and the dumb show she produces to reveal the truth of Agamemnon's murder (III.vi.35-

\footnotetext{
${ }^{175}$ See description of the item, as well as an overview of the myth, on the J.Paul Getty Museum's website, getty.edu.
} 
36) fully ignites, Orestes sets himself on a path towards death similarly caused by blood, both blood ties - the duty a son must show his wronged father — and bloodshed — the excessive action Orestes performs in undertaking revenge. Whether or not he realizes it, here Orestes foreshadows his own fate when he claims that seeing Canidia for the names he seeks will "save a journey for this once from hell" (i.e. he will not need to delve into the underworld himself to ascertain the truth). Although the meeting saves him a one-time trip to hell, the play nonetheless suggests that he will earn a permanent stay there, ${ }^{176}$ as he becomes more and more violent in his desire to obtain vengeance.

As the play continues, the imagery signifying Orestes' initial internal heat becomes increasingly hellish, demonstrating his gradual consumption with violence and revenge as he morphs further into the witch-figure. It is as though Canidia's own associations with hell infiltrate Orestes' mind as his internal fire burns brighter the more he thirsts for bloody revenge. When Orestes first meets her, he asks the gods to protect him from "this hellish sight" (III.v.3), and Canidia herself lays claim to "hell's disturbed spirits / Children of night, such as belong to me" (III.v.71-72). By doing so, Canidia recalls one of the foremost characteristics of being a witch - the intimate connection to hell and the ability to call on the aid of hellish spirits as part of her demonic pact with the devil. It is telling that instead of the gods-upon whom Aeschylus' Orestes calls to drive his revenge: "Zeus, Zeus, send up from below / ground the delayed destruction / on the cruel heart and the all daring hand" (382-384)_-Goffe's Orestes begins to himself call on "fiends of hell" (IV.vii.102) to help him forget his maternal affections or obligations. He pleads, "pious affections take no hold on mee / Be all my senses ordered in with

\footnotetext{
${ }^{176}$ At the end of III.iv before his encounter with Canidia, the stage directions indicate "sound infernall music", a sign of his figurative descent into hell as he begins on a dangerous and horrific path from which there will be no return.
} 
Fiends" (IV.vii.108-109). Here, Orestes explicitly rejects conventional moral values in favour of aligning himself with the fiends of hell upon whom he calls for aid, thereby symbolically binding himself to them like the witch does, especially as he spills much blood - the seal of a demonic pact, especially with male witches - in the course of this pseudo-alliance.

However, though he is unabashedly proud of the revenge he accomplishes, later, in his brief bout of madness, ${ }^{177}$ Orestes shouts, almost helplessly, "Lash on, lash on, Canidia" (V.iii.57). Here, he figures himself as the one being spurred, or whipped, to act through the witch's coercion. However, the use of the imperative is intriguing in that it inadvertently puts Orestes in the position of the commander, thereby revealing that it is not truly Canidia who has forced him to his actions, though it is her influence which has fueled his already-present internal fire to the point of hellish violence and demise. This deflection is reminiscent of Somers' attempt to blame Darrel for his witch-like behaviour, going so far as to claim feigning. While Darrel decries such accusations, and calls them another witch-like deception from Somers, one who has dallied with devils, Orestes is arguably unsuccessful in his attempt to blame Canidia persuasively. After all, it is he who has undertaken heinous action against the advice of friends and family, indeed intending to supersede the violent suggestions of the witch herself.

Just as Macbeth finds himself metaphorically tied to the stake, unable to fly at the end of the play, so Orestes tells Canidia, "I'll follow thee to hell" (V.iii.61).In both cases, the eponymous protagonists pursue their needs to fulfill a particular place in the patriarchal structure through extreme violence which comes to be characterized as necessary in order for the cycles of

\footnotetext{
${ }^{177}$ While with Aeschylus' Orestes, madness comes as a result of not avenging his father- 'there's a dark weapon of those dead men underground / all those within my family who fell turn to call / upon me; madness and empty terror in the night" (285-87) — Goffe's Orestes falls into madness after his matricide. This links his violent action, which he undertakes in the first place to solidify his position in the patriarchal structure by adhering to its filial codes, to madness, thereby implicitly drawing a connection between codes of masculinity and madness, as in Macbeth, rather than with reason, as is the conventional association.
} 
paternal inheritance and authoritative rule to continue. But Shakespeare and Goffe emphasize the influence of witchcraft in unveiling and exacerbating ingrained tendencies towards violence which not only characterize traditional male roles, but more significantly, align the male protagonists with witches themselves, thereby gesturing towards the complicated implications of a system that persecutes certain people for actions and natures of which it, too, is similarly guilty.

\section{$\underline{4.6 \text { Coda }}$}

Although Macbeth and Orestes traverse similar paths throughout their respective plots, they meet vastly different ends. While the tyrant Macbeth is beheaded by the triumphant MacDuff, Orestes falls on his own sword in the arms of his best friend, Pylades. Wendy Trevor has noted that Goffe seems particularly interested in male friendship, as he spends much time portraying Pylades as the loyal friend to Orestes who "understands fidelity in adversity and union in friendship" (113). I believe that because Orestes is able to maintain this friendship, while Macbeth murders his Pylades-equivalent, Banquo, he subsequently regains a softer humanity at the very end which allows him to, in recognizing his own brutality, punish himself for the wrongs he has committed, rather than being forced down by enemies as Macbeth is. Indeed, Orestes and Pylades share a bond akin to the kindred spirituality of Clermont and the Guise, which I discussed in chapter two. Orestes refers to Pylades as "my dearest friend, my other selfe" (I.iii.1), and Pylades, in turn, tries to comfort Orestes in his grief by reassuring him, "I'll be thy brother, nay, I'll be thy selfe, / Weepe when thou weep'st, and where thou goest I'll go" (II.ii.89). It is as though Pylades sees through Banquo's potential to pull his friend back from the brink of madness, had Macbeth not killed him in order to secure his position as king. ${ }^{178}$

\footnotetext{
${ }^{178}$ Marina Favila argues that to subvert conscience and continue pursuing his desire (his security), Macbeth "must not only murder all who stood in his way but also that part of him that still clings to guilt, honour and remorse" (14)
} 
Arguably, Pylades' reappearance at the end of the play brings Orestes out of his madness, and calms his fiery rage to the point of remorse. While it is unclear whether Orestes is aware of his friend's presence, as Pylades laments the state of his friend's deteriorating mind, it is only after Pylades enters and begins to speak soothingly to Orestes that he turns from the violent imaginings of his mother's murder, crying "it bleeds, it bleeds" (V.vii.60). This is one of the first signs of true remorse that we get from Orestes, as it is likely that the ambiguous "it" to which he refers is his own heart; overwhelmed by the amount of blood he has shed, it now bleeds with a guilt with which Orestes' mind cannot sanely cope. The only option becomes death, whereby Pylades claims "we'll free ourselves from all calamity" (V.v.17). It is significant that Pylades uses the encompassing "we", as his soothing influence on Orestes does not excuse him from his own part in the violence Orestes undertakes, especially as Trevor notes that Pylades becomes a willing co-conspirator in Orestes' revenge scheme (117). Pylades willingly volunteers to aid Orestes with his revenge (III.ii.75-77), thereby implicitly legitimizing the practice and making himself complicit in it. ${ }^{179}$ It is also Pylades who comes up with the plan to disguise themselves in order to smuggle themselves into the house undetected, in order to take the murderers by surprise (IV.ii.54-61) — he, thus, not only sanctions the revenges, but also provides Orestes the means to enact his it. Moreover, we might recall that Pylades is the one who recommends Canidia to Orestes and so he who he is partially responsible for the hellish fire which grows in Orestes afterwards and leads him to gross violence and madness. Like MacDuff, Pylades is, thus, imbued in the same system of male aggression and violence as Orestes, and Macbeth too, and so the

which Banquo represents. Irving Ribner suggests as much when he claims that Banquo represents the "humanity which Macbeth must destroy within himself before he can give himself over to the forces of darkness" (153).

${ }^{179}$ I should note here that Pylades cautions Orestes to temper his rage until he discovers for certain the identity of the murderers (as a solution, he recommends seeking Canidia) (III.ii.42-59). However, he also says that from biding their time, "from smallest sparks, great flames may one day rise" (77) - here, the use of the heat imagery perpetuates (and recognizes) the internal fury to the point of hellish overflow which Orestes experiences, and Pylades use of the collective "we" in his speech signifies his own willing participation in fanning those flames of revenge. 
influence of patriarchal codes of masculinity and duty (friendship included) extends even to those men who appear most temperate and rational.

The degree to which Orestes' suicide redeems his horrible actions is debatable; arguably the very act itself recalls the murders committed and so rather than appear pitiable, Orestes dies yet with the stain of his crimes upon him, not unlike Somers who, even after his "dispossession" continues to be marked by signs of witchcraft. However, we might consider that Orestes' action does demonstrate a remorse which Macbeth only minimally achieves. At the end of Darrel's pamphlet, readers are left with unanswered questions and uncertainty, not only about whether the witch-like Somers was punished, but about whether or not he learned anything or, indeed, if there was any moral in the story of a man who encountered a witch and seemed to fall so far under her influence as to become her equal. While Macbeth's final stand against MacDuff, despite knowing his doom is inevitable, does not suggest that the Scottish king transcends the problematic values of violence and aggression that motivated him to action, Orestes' suicide, at least, demonstrates his attempt to escape them in the only way he sees fit. 


\section{Conclusion}

My dissertation has demonstrated how the supernatural presence in early modern English drama can be critically analyzed as sources of psychological and cultural disturbance. Rather than being foreign and unnatural entities, the ghost, devil and witch actually operate from within the systems of religion, morality and politics that govern the larger social order. By analyzing a range of works by different Elizabethan and Jacobean playwrights, I have argued that ghosts, devils and witches across the Renaissance dramatic spectrum can be evaluated as more than mere plot devices or representations of psychological states void of their own ontological meaning. Instead, their ontology is a key contributor to how they affect the minds and mentalities of the human characters they encounter.

Rooted in the same theological and philosophical systems which prescribe early modern beliefs about the co-operative nature of mind and soul, ghosts, devils and witches underscore the complicated ties between seventeenth-century conceptions of reason and imagination, will and appetite, masculine and feminine, right and wrong. The ghosts of Old Hamlet and Andrugio manifest ancestral memory which their living sons must honour through a revenge act, even as that obligation to their dead fathers forces Hamlet and Antonio to confront moral dilemmas as they risk traversing past the bounds of reason. The Lady's ghost and the ghost of the Guise, too, operate through their memorial significance, recalling intense emotional attachments for Govanius and Clermont which prompt actions that obscure traditional ideas of masculinityparticularly as the intimate connection each man feels for the person whose spirit he encounters draws him to the brink of irrationality and, in Clermont's case, right over it. The Weird Sisters and Canidia also test the limits of Macbeth's and Orestes' reason and moral compasses, as they present supposed truths which confirm the protagonists' pre-existent feelings, and so allow them to justify transgressing universal codes of right, good and even justice for the sake of acting on 
those truths. However, in so doing, both Orestes and Macbeth demonstrate moral weakness and aggressive impulsivity in attempting to adhere to patriarchal codes of power and inheritance, effectually complicating traditional gender criteria associated with men and women.

Mephistopheles and the succubus confront Faustus and Penitent Brothel with similar dichotomous dilemmas. In the latter case, the she-devil calls into question the validity of the moral constitutions often ascribed to men and women, by forcing Penitent to confront his own role in creating a mental projection of a promiscuous Mistress Harebrain, on whom he might, therefore, place the blame for their entire affair in order to exonerate himself. The succubus, thus, suggests that men like Penitent should re-evaluate their own potential for immorality, while recognizing that some of the more negative gender qualities presumed of women may not be accurate or, at the very least, are not gender-specific. For Faustus, his contract with the devils pits his own will — the rational ability which defines his scholarly mastery over the natural world — against his appetite — the desire to transcend earthly knowledge and gain power over the spiritual realm. However, his appetite overwhelms him to the point where his will becomes altogether ineffectual, and Faustus becomes bound to Mephistopheles and, in turn, to his own fears of damnation. Marlowe challenges conventional religious doctrine by aligning the lures of the appetite, the Icarus-like desire to venture into realms of unknowing regarding the afterlife where no human has any right to dwell, with religious belief, suggesting preference for earthly knowing that keeps man's imagination within the limits of what he can discover without losing his sense of self.

It does seem that while my discussions have largely delved into issues of gender and politics, Faustus and his struggle with despair and knowing are somewhat disconnected. However, as I implied in the introduction, my aim with this project was to provide a sample 
scope of the ways the supernatural might prompt psychological resistance against various ideological beliefs, particularly concerning structures of gender and power in early modern England (the former arguably being a symptom of the latter). The Church of England was one of the most powerful institutions in Elizabethan and Jacobean England, and many people relied on its theological doctrines for guidance on how they should live, especially in terms of how their present state could influence their afterlives. By analyzing Faustus' relationship to religious despair in addition to issues around patrilinearity in Hamlet and gender in A Mad World, My Masters, for example, I sought to consider multiple avenues of belief-political, social and religious - on which supernatural characters of the early modern stage might comment.

While I have tried to provide a broad range of ways we might interpret and analyze the function of supernatural characters in early modern drama, particularly in the ways they affect the human characters the encounter, I know that the work I was able to do within the scope of this project alone is, inevitably, incomplete, as there are many other playwrights, works and figures I might consider in order to expand, and complicate, my central thesis. In an extended version of this project, I hope to include a few more portrayals of the witch, particularly Erictho in Marston's Sophonisba and Hecate in Middleton's The Witch-like the Weird Sisters and Canidia, these are witch-figures that are inherently supernatural, and so ambiguous, figures because their exact nature cannot be known. They also have complicated, yet intriguing, effects on the male characters they ensnare because they manipulate them using the kind of hypersexuality stereotypical of the early modern witch. I would also like to eventually address another supernatural figure which I have had to omit here, not only because of time and length restrictions, but because it is arguably the least related to the others I do discuss: the fairy. ${ }^{180}$

\footnotetext{
${ }^{180}$ Alongside fairies, I would also consider ambiguous spirits like Ariel in The Tempest, who seems to straddle boundaries between fairy and devil.
} 
Fairies occupy a fascinating place in early modern culture — often, like ghosts, dismissed as figures of archaic and peasant belief while nonetheless holding a place in several contemporary records of supernatural encounter. ${ }^{181}$ Unlike the ghost, the witch and the devil, the fairy was not primarily a theological figure, but one rooted in folklore. Playwrights like Shakespeare and Ben Jonson manipulate popular tales of fairylore in their dramatic portrayals in ways that allow them to explore specific modes of thinking in their time. The fairy antics of $A$ Midsummer Night's Dream, for example, unearth in Helena a series of rational doubts about her own desirability, but also about the nature of her relationships to other people. In such instances, the fairy becomes another supernatural figure through which we might analyze the psychological complexities of what it means to be human in the sixteenth and seventeenth centuries.

I stated at the beginning that aside from analysing the role of supernatural characters in drama, I also wanted to suggest that the early modern theatre is a significant site for visualizing the psychological implications of supernatural encounter, more so than other contemporary circulated materials (pamphlets, tracts etc.). I have accomplished this by interweaving my literary readings with pamphlet analyses in order to emphasize the liberties playwrights might take in gesturing towards socio-political critique, where pamphleteers were often constrained by their primary task of relaying the tales of others and/or the pressure to adhere to the ideological beliefs of the patrons to whom they were beholden. ${ }^{182}$ Because of its tendency to present versions

\footnotetext{
${ }^{181}$ See, most notably, the account of Ann Jeffries, discussed by both Emma Wilby and Peter Marshall.

${ }^{182}$ While many of the records proved incomplete or inadequate in providing a sense of the psychological impact encounters with ghosts or the devil had on the victims at the centres of the tales, they did nonetheless reveal surprising aspects of the changing nature of belief in the period. I am thinking particularly of the pamphlet in the second half of chapter one about the Gentleman's Ghost, which the author advocates as authentic in order to combat the growing threat of atheism - it was more productive, by the middle of the seventeenth-century, to lean towards old papal beliefs in order to recuperate the community of believers in general against those who would blaspheme against the existence of God.
} 
of reality and truth that may differ from the ones promoted by domineering institutions who can use propagated belief to their own advantages, drama becomes perhaps the most appropriate medium for exploring the potential of the supernatural — the two are similar in their transformative potential. Indeed, Andrew V. Ettin compares playwrights like Shakespeare to magicians (to Prospero in particular, who, several scholars have suggested, Shakespeare created as a kind of self-portrait), as they are both "trying to exert mental power over nature" (287). Andrew Sofer likewise observes, "if magic is, ultimately, a phenomenological practice - the art of changing consciousness at will, that is, of persuading others to accept an individual's version of reality...then theatre's power to affect audiences...suggests it deserves a place alongside divinity and law as a site of performative efficacy" (12). If the Crown and the Church are notable institutions because of their ability to influence the minds of the people, to affect the way they think and what they believe, then I think Sofer is absolutely correct in suggesting that early modern theatre, too, has proved their equal in its potential to do the same. 


\section{Bibliography}

Adelman, Janet, “'Born of Woman': Fantasies of Maternal Power in Macbeth", William Shakespeare's Macbeth, edited by Harold Bloom, Infobase Publishing, 2010, pp. 33-60.

Aeschylus, "The Libation Bearers”, Greek Tragedies II,_edited by Mark Griffith and Glene W. Most, University of Chicago Press, 2013.

Aggeler, Geoffrey, “The Unity of Chapman's The Revenge of Bussy D'Ambois", Pacific Coast Philology, vol. 4, 1969, pp. 5-18.

Alsop, James, Playing Dead: Living Death in Early Modern Drama, University of Exeter, 2014.

Alwes, Derek, "The secular morality of Middleton's city comedies”, Comparative Drama, vol. 42 no. 2, 2008, pp. 101-125.

Amussen, Susan D. and David E. Underdown, Gender, Culture, and Politics in England, 15601640: Turning the World Upside Down, Bloomsbury Publishing, 2017.

---."The Part of a Christian Man: The Cultural Politics of Manhood in Early Modern England," Political Culture and Cultural Politics in Seventeenth-Century England, eds. Susan D. Amussen and Mark A. Kishlansky, Manchester UP, 1995, pp. 213-233.

Anderson, Anthony, The shield of our safetie: set foorth by the faythfull preacher of Gods holyeworde A. Anderson, vpon Symeons sight, in hys Nunc dimittis. Seene and allowed, printed by H. Iackson, 1581, STC (2nd ed.) / 572, Early English Books Online. 28 Aug 2017.

Anderson, David K., "The Theater of the Damned: Religion and the Audience in the Tragedy of Christopher Marlowe”, Texas Studies in Literature and Language, vol. 54 no. 1, 2012, pp. 79-109.

Anon., The apprehension and confession of three notorious witches. Arreigned and by iustice condemned and executed at Chelmes-forde, printed for E. Allide, 1589, STC (2nd ed.) / 5114, Early English Books Online, 14 Oct 2016.

Anon. Fearefull apparitions or The strangest visions that ever hath been heard of. It is a spirit that constantly every night haunts one Mr. Youngs yard in Lumbard-street, neere to the Golden Crosse, which hath played such prancks, and appeared in such severall and horrid shapes, that many divines and other learned men, who have come armed with a full resolution and with an intent to have spoken unto it or (at least) to have look't upon it, in the very attempt thereof have fallen into a kind of a distracted extasie, and were neiither able to speak or stand, to the great wonder and terrour of all that were eye witnesses thereof. 1647 Printed for John Hammond, Wing (2nd ed.) / F576, Early English Books Online. 10 Nov 2018.

Anon., A full and true relation of the examination and confession of $W$. Barwick and E. Mangall, of two horrid murders one committed by William Barwick upon his wife being with child, near Cawood in Yorkshire, upon the 14th. of April last: as likewise a full account how it came to be discovered by an apparition of the person murder'd, 7 Oct 1690, Wing / F2322, Early English Books Online, 9 May 2018. 
Anon., A Great vvonder in heaven shewing the late apparitions and prodigious noyses of war and battels seen on Edge-Hill neere Keinton in Northampton-shire : certified under the hands of William Wood Esquire and iustice for the peace in the said countie, Samuel Marshallpreacher of Gods Word in Keinton and other persons of qualitie. Jan 1642, Wing / G1787, Early English Books Online. 16 Nov 2017.

Anon., A Narrative of the demon of Spraiton in a letter from a person of quality in the county of Devon to a gentleman in London: with a relation of an apparition or spectrum of an ancient gentleman of Devon, who often appeared to his sons servant, with the strange actions and discourses happening between them at divers times: as likewise the daemon of an ancient woman, wife of the gentleman aforesaid, with unparalell'd varieties of strange exploits performed by her :attested under the hands of the said person of quality, and likewise a reverend divine of the said county : with reflections on drollery and atheism, and a word those who deny the existence of spirits, 1683, Wing / N180, EEBO. 23 Aug 2018.

Anon. A Relation of a strange apparition in an ale-house next doore to the White Horse, against Sommerset-House in the strand where a company of papists were at their exercises: as is conceived the devill in an ugly black shape disturbing them, and tearing the rugge and scattering it in pieces up and down the roome : with a relation of a iudgement that strangely fell umpon one at Mr. Mundayeshouse in Little Brittaine: who whilst he was cursing of Mr. Burton, Mr. Prinne and doctor Bastwicke his eares fell a bleeding to the amazement of the beholders. 1641, printed for Richard Smethrust, Wing / R795, EEBO, 10 Nov 2018.

Anon., Strange and terrible news from Shoreditch of a woman that hath sold her self to the Divel; living in Badger-Alley; and lying at this present in a sad and miserable condition; acknowledging that about six-years since, she made a contract with the Divel written with her own blood, and that her time wasnow, expired within six weeks; and she irrecoverable to all eternity; with the like speeches of dispair. As also, how several able ministers went to comfert her, with her full confession of her former evil life, and other passages between them. With allowance 1674, Wing (2nd ed.) / S5831A, EEBO. 23 Aug 2018.

Anon., A Strange, but true, relation of a most horrid and bloudy murder committed on a traveller about thirty years ago in the west of England ... here is also anaccount of an apparition to a certain person that was made executor of a will, 1678, Wing / S5881 A, Early English Books Online, 20 Feb 2018.

Anthonisen, Nils L., “The Ghost in Hamlet,” American Imago, vol. 22 no.4, 1965, pp. 232-250.

Aquinas, Thomas, The Summa Theologica. Translated by Father of the English Dominican Province, Benziger Bros., 1947.

Asp, Caroline, “'Be bloody, Bold and Resolute': Tragic Action and Sexual Stereotyping in Macbeth", Studies in Philology, vol. 78 no. 2, 1981, pp. 153-169.

Ayres, P.J., “Marston's Antonio's Revenge : The Morality of the Revenging Hero", Studies in English Literature 1500-1900, vol. 12 no. 2, 1972, pp. 359-374. 
---. "Plot, Subplot, and the Uses of Dramatic Discord in A Mad World, My Masters and A Trick to Catch the Old One", Modern Language Quarterly, vol. 47, no. 1, 1947, pp. 3-18.

Bacon, Francis, The tvvoo bookes of Francis Bacon. Of the proficience and aduancement of learning, diuine and humane To the King, 1605, STC (2nd ed.) / 1164, Early English Books Online, 20 Jan 2018.

Baines, Barbara J., “Antonio’s Revenge: Marston's Play on Revenge Plays,” Studies in English Literature, 1500-1900, vol. 23 no. 2, 1983, pp. 277-294.

Banerjee, Pompa, "I, Mephastophilis: Self, Other, and Demonic Parody in Marlowe's Doctor Faustus", Christianity \& Literature, vol. 42 no. 2, 1993, pp. 221-241.

Barnes, Barnabe, The Divel's Charter, 1607, Tudor Facsimile Texts, 1913.

Barry, Jonathan, Marianne Hester, Gareth Roberts (eds). Witchcraft in Early Modern Europe: Studies in Culture and Belief, Cambridge University Press, 1998.

Baxter, Richard, The certainty of the worlds of spirits and, consequently, of the immortality of souls of the malice and misery of the devils and the damned: and of the blessedness of the justified, fully evinced by the unquestionable histories of apparitions, operations, witchcrafts, voices \&c, 1691, Wing / B1214, Early English Books Online, 28 Aug 2017.

Beaumont, John. An Historical, Physiological and Theological Treatise on Spirits, Apparitions and Witchcraft, printed for D. Browne, 1705, The British Library, 719.h.23, 10 Oct 2017.

Bennett, Gillian, "Ghost and Witch in the Sixteenth and Seventeenth Centuries", Folklore, vol. 97 no. 1,1986 , pp. 3-14.

Berger, Thomas, William C. Bradley and Sidney L. Sondergard, An Index of Characters from Early Modern Drama: Printed Plays 1500-1660, Cambridge University Press, 2015.

Bergson, Allen, “The Worldly Stoicism of George Chapman's The Revenge of Bussy D'Ambois and The Tragedy of Chabot, Admiral of France", Philological Quarterly, vol. 55 no. 1, 1976, pp. 43-65.

Bever, Edward, "Witchcraft, Female Aggression, and Power in the Early Modern Community", Journal of Social History, vol. 35 no. 4, 2002, pp. 955-988.

Bowers, Fredson, Elizabethan Revenge Tragedy 1587-1642. Princeton University Press, 1959.

Bradley, Andrew C., Shakespearean Tragedy: Lectures on Hamlet, Othello, King Lear and Macbeth, Macmillan, 1992.

Breuer, Heidi, Crafting the Witch: Gendering Magic in Medieval and Early Modern England, Routledge, 2009.

Briggs, Katherine Mary, The Fairies in Tradition and Literature, Psychology Press, 2002.

Briggs, Robin, “Male Witches in the Duchy of Lorraine”, Rowlands, pp. 31-51. 
---. “"Many reasons why': Witchcraft and the problem of multiple explanation”, Barry, pp. 4963.

Brooks, Cleanth, "The Unity of Marlowe's Doctor Faustus", Doctor Faustus: A Norton Critical Edition, edited by David Scott Kastan, W.W Norton \& Company Inc., 2005, pp. 281-290.

Broude, Ronald, "Revenge and Revenge Tragedy in Renaissance England", Renaissance Quarterly, vol. 28 no. 1, 1975, pp. 38-58.

Brown, John Russell (ed)., Focus on Macbeth, Routledge, 2005.

Bryskett, Lodowick, A discourse of ciuill life containing the ethike part of morall philosophie. Fit for the instructing of a gentleman in the course of a vertuous life, Printed by R. Field, 1606, STC (2nd ed.) / 3959, EEBO, 26 Sep 2019.

Burnet, Gilbert, Bishop of Sarum. An exposition of the Thirty-nine articles of the Church of England, Printed by R.Roberts, 1700, Wing / B5792, EEBO, 9 July 2019.

Burton, Robert, The anatomy of melancholy vvhat it is. VVith all the kindes, causes, symptomes, prognostickes, and seuerall cures of it. In three maine partitions with their severall sections, members and subsections. Philosophically, medicinally, historically, opened and cut vp, printed by John Lichfield and James Short, 1621, STC (2nd ed.) / 4159, Early English Books Online. 12 Sept 2017.

Calvin, John, Institutes of the Christian Religion, ed. John T. McNeill, trans. Ford Lewis Battles, Westminster Press, 1960, Book 1.14.19.

Cameron, Euan, Enchanted Europe: Superstition, Reason and Religion 1250-1750, Oxford University Press, 2010.

Carrafiello, Michael L., "St. Paul and the Polemicists: The Robert Parson-Thomas Morton Exchanges 1606-10", The Catholic University of America Press, vol. 95 no. 3, 2009, pp. 474-490.

Chapman, George, The Revenge of Bussy D'Ambois, The Plays of George Chapman: The Tragedies Volume 1, edited by T.M. Parrott, Russell \& Russell Inc., 1961, pp. 75-148.

Chesters, Timothy, Ghost Stories in Late Renaissance France: Walking By Night, Oxford University Press, 2011.

Church of England, Articles agreed upon by the arch-bishops and bishops of both provinces, and the whole clergie; in the convocation holden at London, in the year, 1562. For the avoiding of diversities of opinions, and for the establishing of consent touching true religion. Reprinted by His Majesties commandment: with His royal declaration prefixed thereunto, Printed by Bonham Norton and John Bill, 1630, STC (2nd ed.), / 10053. EEBO, 26 Sep 2019.

Clark, Sandra, "Macbeth and the Language of the Passions", Shakespeare, vol. 8 no. 3, 2012, pp. 300-311. 
Clark, Stuart, "Inversion, Misrule, and the Meaning of Witchcraft," Past and Present, vol. 87, 1980, pp. 98-127.

---. Language of Witchcraft: Narrative, Ideology, and Meaning in Early Modern Culture, Macmillan, 2017.

---. Thinking with Demons: The idea of witchcraft in early modern Europe, Oxford University Press, 1997.

---. Vanities of the Eye: Vision in Early Modern European Culture, Oxford University Press, 2007.

---. "Witchcraft and Magic in Early Modern Culture", Parish, pp. 215-274.

Cochrum, Alan Morris, "Becomes a woman best”: Female Prophetic Figures in Shakespeare's Plays, The University of Texas at Arlington, 2015.

Coddon, Karin S., "'Suche Strange Desyns': Madnessm Subjectivity and Treason in Hamlet and Elizabethan Culture", Renaissance Drama, vol. 20, 1989, pp. 51-76.

---. "'Unreal Mockery': Unreason and the Problem of Spectacle in Macbeth", ELH, vol. 56 no. 3, 1989, pp. 485-501.

Cole, Douglas, "Doctor Faustus and the Morality Tradition”, Doctor Faustus: A Norton Critical Edition, edited by David Scott Kastan, W.W Norton \& Company Inc., 2005, pp. 304-311.

Cooper, Karol, “The Modernisation of the Medieval Staging of theSoul in Marlowe's Doctor Faustus", Early Modern Literary Studies, vol. 23, 2014, pp. 1-17.

Cooper, Thomas. Sathan transformed into an angell of light expressing his dangerous impostures vnder glorious shewes. Emplified [sic] specially in the doctrine of witchcraft, and such sleights of Satan, as are incident thereunto. Very necessary to discerne the speciplague raging in these dayes, and so to hide our selues from the snare thereof. Printed by Barnard Alsop, 1622, STC (2nd ed.) / 5701.3, EEBO 20 Jan 2019.

Cox, John D., The Devil and the Sacred in English Drama 1350-1642, Cambridge University Press, 2000.

---. "Devils and Power in Marlowe and Shakespeare", The Yearbook of English Studies, vol. 23, 1993, pp. 46-64.

Crooke, Helkiah, Mikrokosmographia a description of the body of man, together with the controversies and figures thereto belonging / collected and translated out of all the best authors of anatomy, especially out of Gasper Bauhinus and Andreas Laurentius, by Helkiah Crooke ...published by the Kings Maiestiese speciall direction and warrant, according to the first integrity, as it was originally written by the author., 1616, STC (2nd ed.) / 6062.2 Early English Books Online, 7 May 2017.

Curry, Walter Clyde, "The Demonic Metaphysics of Macbeth", Studies in Philology, vol. 30 no. 3, 1933, pp. 395-426. 
Darrel, John. A true narration of the strange and greuous vexation by the Devil, of 7. persons in Lancashire, and VVilliam Somers of Nottingham Wherein the doctrine of possession and dispossession of demoniakes out of the word of God is particularly applyed vnto Somers, and the rest of the persons controuerted: togeather with the vse we are to make of these workes of God. 1600, STC (2nd ed.) / 6288, Early English Books Online. 21 Feb 2019.

Davidson, Clifford, "Doctor Faustus of Wittenberg”, Studies in Philology, vol. 59 no. 3, 1962, pp. 514-523.

Dekker, Thomas, If it be not good, the Divell is in it, 1612, STC (2nd ed.) / 6507, Early English Books Online, 11 Jan 2017.

---. Massinger, Philip, The Virgin Martyr, 1620, edited by James Burns, 1844.

---. Rowley, William and John Ford, The Witch of Edmonton, 1621, edited by Ernest Rhys, T. Fisher Unwin, 2006.

Degen, Andreas, "Concepts of Fascination, from Democritus to Kant", Journal of the History of Ideas, vol. 73, no. 3, 2012, pp. 371-393.

Dollimore, Jonathan, Radical Tragedy: Religion, Ideology, and Power in the Drama of Shakespeare and his Contemporaries, Third Edition, Palgrave Macmillan, 2010.

---. "Subjectivity, Sexuality and Transgression: The Jacobean Connection", Renaissance Drama, vol. 17, 1986, pp. 53-81.

Dreher, Diane, "Abnormal Psychology in the Renaissance", Abnormal Psychology Across the Ages, edited by Thomas G. Plante, ABC-CLIO, 2013, pp. 33-50.

Edwards, Kathryn A., Werewolves, Witches and Wandering Spirits: Traditional Folklore in Early Modern Europe, Truman State University Press, 2002.

Edwards, Michael, Time and the Science of the Soul in Early Modern Philosophy, Brill, 2013.

Elmer, Peter, “'Saints or sorcerers': Quakerism, demonology, and the decline of witchcraft in seventeenth-century England”, Barry, pp. 145-182.

Encyclopedia Brittanica, "Battle of Edge-Hill”, 8 Mar 2018.

---."Catherine de Medici”, 20 May 2018.

---. "Sadducees", 10 Mar 2018.

"Essays of Michel de Montaigne", translated by Charles Cotton, Project Gutenberg, 23 May 2018.

Ettin, Andrew V., "Magic into Art: The Magician's Renunciation of Magic in English Renaissance Drama", Texas Studies in Literature and Language, vol. 19 no. 3, 1977, pp. 268-293.

Favila, Marina, "'Mortal Thoughts' and Magical Thinking in Macbeth", Modern Philology, vol. 99 no. 1, 2011, pp. 1-25. 
Finucane, R.C., Ghosts: Appearances of the Dead and Cultural Transformation, Prometheus Books, 1996.

Fisher, Anne Louise, The power of a "naughty name": Performing witchcraft in early modern England, The Pennsylvania State University, 2000.

Fletcher, Angus, “Doctor Faustus and the Lutheran Aesthetic”, English Literary Renaissance, vol. 35 no. 2 , 2005, pp. 187-209.

Fletcher, John, The Prophetess, The Works of Beaumont and Fletcher, Vol. 2, George Routledge and sons, 1872, pp. 1-22.

Floyd-Wilson, Mary, "English Epicures and Scottish Witches”, Shakespeare Quarterly, vol. 57 no. 2, 2006, pp. 131-161.

---."'Some Fury Pricks Me On': Satanic Thinking in Thomas Heywood's A Woman Killed with Kindness", Embodied Cognition and Shakespeare's Theatre: The Early Modern Body-Mind, edited by Laurie Johnson, John Sutton and Evelyn Tribble, Routledge, 2014, pp. 71-85.

Foakes, R.A., "Hamlet's Neglect of Revenge”, Hamlet: New Critical Essays, edited by Arthur Kinney, Routledge, 2002, pp. 85-100.

---. "Images of Death: Ambition in Macbeth", Brown, pp. 7-29.

Frans van Dijkhuizen, Jans, Devil theatre: Demonic Possession and Exorcism in English Renaissance Drama 1558-1642, D.S Brewer, 2007.

Fromman, Johann Christian, Tractatus de fascinatione novus et singularis, Nuremberg 1675 , The British Library, 719.f.25, 1 Feb 2018.

Fudge, Erica, Brutal Reasoning: Animals, Rationality, and Humanity in Early Modern England, Cornell University Press, 2006.

---. “'Onely Proper Unto Man': Dreaming and Being Human in the Renaissance”, Reading the Early Modern Dream: The Terrors of the Night, edited by Katherine Hodgkin, Michelle O’Callaghan and S.J. Wiseman, Routledge, 2008.

Fulke, William, Tvvo treatises written against the papistes the one being an answere of the Christian Protestant to the proud challenge of a popish Catholicke: the other a confutation of the popish churches doctrine touching purgatory \& prayers for the dead, 1577, STC (2nd ed.) / 11458, EEBO, 26 Sep 2019.

Galen, Claudius, Certaine vvorkes of Galens, called Methodus medendi with a briefe declaration of the worthie art of medicine, the office of a chirurgion, and an epitome of the third booke of Galen, of naturall faculties, edited and translated by Thomas Gale, printed by Thomas East, 1586, STC (2nd ed.) / 11531, Early English Books Online, 12 Sept 2017.

Gaskill, Malcolm, "The Devil in the shape of a man: Witchcraft, conflict and belief in Jacobean England", Historical Research, vol. 71 no. 175, 1998, pp. 142-171.

---. "Masculinity and Witchcraft in Seventeenth-Century England", Rowlands, pp. 171-190. 
--- "Witchcraft and Evidence in Early Modern England", Past \& Present, vol. 198 no. 1, 2008, pp. 33-70.

---. Witchcraft in early modern Kent: Stereotypes and the background to accusations", Barry, pp. 257-287.

Gibson, Marion. Early Modern Witches: Witchcraft Cases in Contemporary Writing, Routledge, 2001.

Gifford, George, A dialogue concerning vvitches and witchcrafts In which is layed open how craftily the Diuell deceiueth not onely the vvitches, but many other, and so leadeth them awrie into manie great errours, printed by Richard Field and Felix Kingston, 1603, STC (2nd ed.) / 11851, Early English Books Online, 19 Feb 2019.

---. A discourse of the subtill practises of deuilles by vvitches and sorcerers By which men are and haue bin greatly deluded: the antiquitie of them: their diuers sorts and names, printed by T. Orwin, 1587, STC (2nd ed.) / 11852, Early English Books Online, 19 Feb 2019.

Giglioni, Guido, “Coping with Inner and Outer Demons: Marsilio Ficino's Theory of the Imagination", Diseases of the Imagination and Imaginary Disease in the Early Modern Period, edited by Yasmin Haskell, Brepols, 2011, pp. 19-51.

Gil Harris, Jonathan, Foreign Bodies and the Body Politic: Discourse of Social Pathology in Early Modern England, Cambridge University Press, 1998.

“Gospel of Luke 23:46”, The Bible. Authorized King James Version, Oxford UP, 1998.

Golden, Kenneth L., "Myth, Psychology, and Marlowe's Doctor Faustus", College Literature, vol. 12 no. 3, 1985, pp. 202-210.

Goodland, Giles, "Reading Early Modern literature through OED", Multilingualism in the Drama of Shakespeare and His Contemporaries, edited by Dirk Delabastita, Ton Hoenselaars, John Benjamins Publishing Company, 2015, pp. 17-40.

Gowland, Angus, "Burton's Anatomy and the Intellectual Traditions of Melancholy", Babel Litteratures plurielles, vol. 25, pp. 221-257.

---. "The Problem of Early Modern Melancholy", Past \& Present, vol. 191 no. 1, 2006, pp. 77-120.

Greenblatt, Stephen, Hamlet in Purgatory, Princeton University Press, 2001.

---. Renaissance Self-Fashioning, University of Chicago Press, 1983.

---. "Shakespeare Bewitched", Shakespeare and Cultural Traditions, edited by Tetsuo Kishi, Roger Pringle and Stnaley Wells, University of Delaware Press, 1991, pp. 17-42.

Greene, Robert, The History of Orlando Furioso, The Dramatic and Poetical Works of Robert Greene and George Peele, Ed. Alexander Dyce, Routledge, 1861, pp. 89-118.

Guenther, Genevieve, "Why the Devils came when Faustus called them." Modern Philology, vol. 109 no.11, 2011, pp. 46-70. 
Hall, David D, "Witchcraft and the Limitations of Interpretation," New England Quarterly, vol.58 no.1, 1985, pp. 253-281

Hallett, Charles, "Andrea, Andrugio and King Hamlet: The Ghost as Spirit of Revenge," Philological Quarterly, vol. 56 no. 1, 1977, pp. 43-65.

---. "Penitent Brothel, the Succubus and Parsons' 'Resolution': A Reappraisal of Penitent's Position in Middleton's Canon", Studies in Philology, vol. 69 no. 1, 1972, pp. $72-85$.

Hallett, Charles and Elaine, “Antonio's Revenge and the Integrity of the Revenge Tragedy Motifs," Studies in Philology, vol. 76 no. 4, 1979, pp. 366-386.

Hankins, James, "Monstrous Melancholy: Ficino and the Physiological Causes of Atheism", Laus platonici Philosophi: Marsilio Ficino and His Influence, edited by Stephen Clucas, Peter J. Forshaw and Valery Rees, Brill, 2011, pp. 25-44.

Hanson, Elizabeth, Discovering the subject in Renaissance England, Cambridge University Press, 1998.

Hattaway, Michael, “The Theology of Marlowe's Doctor Faustus", Renaissance Drama, vol. 3, 1970, pp. 51-78.

Heller, Herbert Jack, Penitent brothellers: Grace, sexuality and genre in Thomas Middleton's city comedies, ProQuest Dissertations Publishing, 1997.

"Hercules Poisoned by the Shirt of Nessus", J. Paul Getty Museum, getty.edu. 23 Apr. 2019.

Hester, Marianne, "Patriarchal reconstruction and witch-hunting", Barry, pp. 288-308.

Heywood, Thomas, II Edward IV, 1600, Ed. Baron Field, The Shakespeare Society, 1842.

---. The Wise Woman of Hoxton, 1604, edited by Sonia Massai, Taylor \& Francis, 2003.

Higgins, Michael H., “Chapman's 'Senecal Man', A Study in Jacobean Psychology”, The Review of English Studies, vol. 21 no. 83, 1945, pp. 183-191.

Hirsh, James, Shakespeare and the History of Soliloquies, Fairleigh Dickinson University Press, 2003.

Honderich, Pauline, "John Calvin and Doctor Faustus", The Modern Language Review, vol. 68 no. 1, 1973, pp. 1-13.

Horney, Karen. "The Struggle toward Self-Realization," The Self in Social Interaction Vol I: Classic and Contemporary Perspectives, Eds. Chad Gordon and Kenneth J. Gergen, John Wiley \& Sons Inc., 1968, pp. 401-404.

Howard, Jean E., Shakespeare's Ghost Writers: Literature as Uncanny Causality, Routledge, 2010.

Hutchins, Randall. Of Specters, 1593, Huntington Library Quarterly, vol. 11, 1948, pp. 407-429. 
Ide, Richard, "The Theatre of the Mind: An Essay on Macbeth", ELH, vol. 42, no. 3, 1975, pp. 338-361.

James I. Daemonologie. Printed by Robert Walde, 1597, STC (2nd ed.) / 14364, Early English Books Online, 2 Sep 2018.

Jeffreys, M.D.W., "The Weird Sisters in Macbeth", English Studies in Africa, vol. 1 no. 1, 1958, pp. 43-55.

Johnson, Sarah E., Staging Women and the Soul-Body Dynamic in Early Modern England, Routledge, 2016.

Johnstone, Nathan, “The Protestant Devil: The Experience of Temptation in Early Modern E England", Journal of British Studies, vol. 43 no. 2, 2004, pp. 173-205.

---. The Devil and Demonism in Early Modern England, Cambridge University Press, 2006.

Jones, Ernest, "The Oedipus Complex as an Explanation of Hamlet's Mystery: A Study in Motive," The American Journal of Psychology, vol. 21 no. 1, 1910, pp. 72-113.

Jonson, Ben. Catiline, The Holloway Pages, 26 Sept 2017.

---. Masque of Queens, The Holloway Pages, 25 Apr. 2019.

---. Oberon, the Fairy Prince. A Masque of Prince Henry's, Phillips, Sampson and Company, 1853.

Josephson-Storm, Jason A., The Myth of Disenchantment: Magic, Modernity, and the Birth of the Sciences, University of Chicago Press, 2017.

Keller, James Gregory, “The Moral Thinking of Macbeth”, Philosophy and Literature, vol. 29 no. 1, 2005, pp. 41-56.

Kemp, Simon, Cognitive Psychology in the Middle Ages, Greenwood Press, 1996.

Kimbrough, Robert, “Macbeth: The Prisoner of Gender”, Shakespeare Studies, vol. 16, 1983, pp. 175-191.

Kistler, Suzanne F., “'Strange and Far-Removed Shores': A Reconsideration of The Revenge of Bussy D'Ambois", Studies in Philology, vol. 77, no. 2, 1980, pp. 128-144.

Kistner, A.L \& M.K. Middleton's Tragic Themes, Peter Lang Publishing Inc., 1955.

Kranz, David L., "The Sounds of Supernatural Soliciting in Macbeth", Studies in Philology, vol. 100 no. 3,2003 , pp. 346-383.

Kuchar, Gary, "Rhetoric, Anxiety, and the Pleasure of Cuckoldry in the Drama of Ben Jonson and Thomas Middleton", Journal of Narrative Theory, vol. 31 no. 1, 2001, pp. 1-30.

Kuriyama, Constance Brown, Hammer or Anvil: Psychological Patterns in Christopher M Marlowe's Plays, Rutgers University Press, 1980.

Kyd, Thomas. The Spanish Tragedy, London: A\&C Black Publishers Limited, 2009. 
Lagerlund, Henrik "The Mind/Body Problem and Late Medieval Conceptions of the Soul", Forming the Mind: Essays on the Internal Senses and the Mind/Body Problem from Avicenna to The Medical Enlightenment, edited by Henrik Langerlund, Springer Science \& Business Media, 2007, pp. 1-16.

Lamarra, Antonio, "Experience and identity of the self: The emergence of consciousness as a c cognitive concept in the early modern age," Consciousness in Interaction: The role of the natural and social context in shaping consciousness, Ed. Fabio Paglieri, John Benjamins Publishing Company, 2012, pp. 311-326.

Larner, Christina, Enemies of God: The Witch-hunt in Scotland, John Donald, 2000.

Lavater, Ludwig, Of ghostes and spirites, vvalking by night and of straunge noyses, crackes, and sundrie forewarnings, which commonly happen before the death of men: great slaughters, and alterations of kingdoms, edited and translated by Robert Harrison, printed by Thomas Creede, 1596, STC (2nd ed.) / 15321, Early English Books Online, 5 July 2017.

Leggatt, Alexander, “The Tragedy of Clermont D'Ambois”, The Modern Language Review, vol. 77 no. 3,1982 , pp. 524-536.

Le Loyer, Pierre, A treatise of specters or straunge sights, visions and apparitions appearing sensibly vnto men Wherein is delivered, the nature of spirites, angels, and divels: their power and properties: as also of witches, sorcerers, enchanters, and such like, printed by Val. Simmes, translated by Zachary Jones, 1605, STC (2nd ed.) / 15448, Early English Books Online, 28 Apr. 2017.

Lemon, Rebecca, "Scholarly Addiction: Doctor Faustus and the Drama of Devotion", Renaissance Quarterly, vol. 69, no. 3, 2016, pp. 865-898.

Levack, Brian P., "The Decline and End of Witchcraft Persecutions”, Parish, pp. 336-372

---. "State-building and witch-hunting in early modern Europe", Barry, pp. 96-118.

---. The Witchcraft Sourcebook, Routledge, 2015.

---. The Witch-Hunt in Early Modern Europe, Routledge, 2015.

Levao, Ronald, Renaissance minds and their fictions: Cusanus, Sidney, Shakespeare, University of California Press, 1985.

Lewalski, Barbara, "Anne of Denmark and the Subversions of Masquing”, Criticism, vol. 35 no. 3, 1993, pp. 341-355.

Long, Zachariah C., "The Spanish Tragedy and Hamlet: Infernal Memory in English Renaissance Revenge Tragedy", English Literary Renaissance, vol. 44 no. 2, 2014, pp. 153-192.

Lovel, Henry, Horrid and strange news from Ireland: being a true relation of what happened in the province of Munster, at a castle of one of the FitzGarrets, called Ballimarter, wherein there were very strange apparitions, the like never before heard of, to the amazement of all the beholders, printed for Thomas Harper, 1643, Wing / L3236, Early English Books Online, 3 Apr 2018. 
Lyly, John, Endymion the Man in the Moon, Ed. George B. Parker, Henry Holt and Company, 1894.

MacDonald, Alistair Irwin, “John Marston's Stoicism,” Dissertation, ProQuest Dissertations Publishing, 1973.

MacDonald, James Ross, "Calvinist theology and 'country divinity' in Marlowe's Doctor Faustus." Studies in Philology, vol. 111 no. 4, 2014, pp. 821-840.

Macfarlane, Alan. Witchcraft in Tudor and Stuart England, Routledge, 1999.

Mandel, Jerome, "Dream and Imagination in Shakespeare", Shakespeare Quarterly, vol. 24 no. 1, 2011, pp.61-68

Marcus, Leah, "Textual Instability and Ideological Difference: The Case of Doctor Faustus", Doctor Faustus: A Norton Critical Edition, edited by David Scott Kastan, W.W Norton \& Company Inc., 2005. Pp.153-170.

Marlowe, Christopher, Doctor Faustus, edited by David Scott Kastan. W.W Norton \& Co., 2005.

--. The Massacre at Paris, Christopher Marlowe: The Complete Plays, edited by Frank Romany and Robert Lindsey, Penguin Books, 2003, pp. 507-562.

Martin, Fiona, “'Mong'st the furies finde just recompence': Suicide and the Supernatural in William Sampson's The Vow Breaker," Supernatural and Secular Power in Early Modern England, edited by Marcus Hermes and Victoria Bladen, Ashgate Publishing Ltd., 2015, pp. 117-140.

Marshall, Peter, "Ann Jeffries and the Fairies: Folk Belief and the War on Skepticism in Later Stuart England", The Extraordinary and the Everyday in Early Modern England edited by Angela McShane and Garthone Walker, Springer, 2010, pp. 127-141.

---. "Deceptive appearances: ghosts and reformers in Elizabethan and Jacobean England", Religion and Superstition in Reformation Europe, edited by Helen Parish and William G. Naphy, Manchester University Press, 2002, pp. 188-208.

---. "Protestants and Fairies in Early Modern England", Living with Religious Diversity in Early Modern Europe, edited by M.C. Scott Dixon and Dagmar Freist, Ashgate Publishing Inc., 2009, pp. 139-161.

Marston, John. Antonio's Revenge, edited by W. Reavley Gair, Manchester University Press, 1978.

---. The wonder of women or, the tragedie of Sophonisba, John Windet, 1606.

Masinton, Charles G., "Faustus and the Failure of the Renaissance Man", Doctor Faustus: A Norton Critical Edition, edited by David Scott Kastan, W.W Norton \& Company Inc., 2005, pp. 344-352.

Massinger, Philip, The Roman Actor, Bernard Aslop and Thomas Fawcett, 1629, STC (2nd ed.) / 17642, Early English Books Online, 12 Jan 2017. 
Maus, Katherine Eisaman, Inwardness and the Theater in the English Renaissance, The University of Chicago Press, 1995.

---. "Proof and Consequences: Inwardness and its Exposure in the English Renaissance", Representations, no. 34, 1991, pp. 29-52.

Maxwell-Stuart, P.G., "Rational superstition: The writings of Protestant demonologists", Religion and Superstition in Reformation Europe. Edited by Helen Parish and William G. Naphy. Manchester University Press, 2002, pp 170-187.

McMahon, Chris, Family and the State in Early Modern Revenge Drama, Routledge, 2012.

Middleton, Thomas, The Collected Works edited by Gary Taylor and John Lavagnino, Oxford University Press, 2010.

--. The Changeling, edited by pp. 237-306.

--. A Mad World, My Masters, edited by Peter Saccio, pp. 414-451.

--..Second Maiden's Tragedy, edited by Julia Briggs, pp. 833-906.

--. The Witch, edited by Marion O'Connor, pp. 1124-1164.

---. A Mad World, My Masters, edited by Standish Henning, University of Nebraska Press, 1965.

---. Second Maiden's Tragedy edited by Anne Lancashire, Manchester University Press, 1978.

Millar, Charlotte Rose, Witchcraft, the Devil, and Emotions in Early Modern England, Taylor \& Francis, 2017.

Miola, Robert, "Orestes and the Light of Day", Comparative Drama, vol. 51 no. 4, 2017, pp. 588-602.

---. “Representing Orestes’ Revenge”, Classical Receptions Journal, vol. 9 no. 1, 2017, pp. 144165.

de Montaigne, Michel, “De L’Amitie”, Essais, edited by Marie-Madeleine Fragonard, Pocket Classiques, 1998.

Monter, William, "Toads and Eucharists: The Male Witches of Normandy 1564-1660", Parish, pp. 190-214.

Morris, Brian, "The kingdom, the power and the glory in Macbeth", Brown, pp. 30-53.

Morton, Thomas, The encounter against M. Parsons, by a revievv of his last sober reckoning, and his exceptions vrged in the treatise of his mitigation. Wherein moreouer is inserted: 1. A confession of some Romanists, both concerning the particular falsifications of principall Romanists, as namely, Bellarmine, Suarez, and others: as also concerning the generall fraude of that curch, in corrupting of authors. 2. A confutation of slaunders, which Bellarmine vrged against Protestants. 3. A performance of the challenge, which $M$ Mr. Parsons made, for the examining of sixtie Fathers, cited by Coccius for proofe of Purgatorie ... 4. A censure of a late pamphlet, intituled, The patterne of a Protestant, by one once termed the moderate answerer. 5. An handling of his question of mentall equiuocation (after his boldnesse with the L. Cooke) vpon occasion of the most memorable, and feyned Yorkeshire case of equiuocating; and of his raging against D. Kings sermon, 1610, STC / 1249:04, EEBO, 26 Sep 2019. 
Munson Deats, Sara, "Doctor Faustus: From Chapbook to Tragedy" Doctor Faustus: A Norton Critical Edition, edited by David Scott Kastan, W.W Norton \& Company Inc., 2005, pp. 209-225.

Nashe, Thomas, The terrors of the night or, A discourse of apparitions, printed by John Danter, 1594, STC (2nd ed.) / 18379, Early English Books Online, 16 July 2017.

Northbrooke, John, Spiritus est vicarius Christi in terra. The poore mans garden wherein are flowers of the scriptures, and doctours, very necessarye and profitable for the simple and ignorant people to reade, printed by VV. Williamson, 1571, STC (2nd ed.) / 18663. Early English Books Online. 25 Aug 2017.

Notestein, Wallace, A history of witchcraft in England from 1558 to 1718, The American Historical Association, 1911.

Nuttall, Alfred D., The Alternative Trinity: Gnostic Heresy in Marlowe, Milton and Blake, Clarendon Press, 2007.

O’Donnell, Norbert F., "Shakespeare, Marston and the University: The Sources of Thomas Goffe's Orestes", Studies in Philology, vol. 50 no. 3, 1953, pp. 476-484.

Ornstein, Robert, "Marlowe and God: The Tragic Theology of Dr. Faustus", PMLA, vol. 83 no. 5, 1968, pp. 1378-1385.

Outterson-Murphy, Sarah, Playing dead: Staging corpses, ghosts, and statues in early modern drama, ProQuest Dissertations Publishing, 2015.

Oxford English Dictionary, "massacre", www.oed.com

Palmer, James Foster, Hamlet: A Study in Melancholia, The Medical Magazine, 1911.

Parish, Helen L. (ed.), Superstition and Magic in Early Modern Europe: A Reader, Bloomsbury Publishing, 2014.

Parker, John, "Faustus, Confession, and the Sins of Omission", ELH, vol. 80 no. 1, 2013, pp. 29-59.

Parker, Matthew. The Correspondence of Matthew Parker, edited by John Bruce, Cambridge University Press, 1853.

Peele, George, The Wisdom of Doctor Dodypoll, edited by John S. Farmer, Tudor Facsimile Texts, 1600.

Perkins, William, A discourse of the damned art of witchcraft so farre forth as it is reuealed in the Scriptures, and manifest by true experience, printed by Cantrel Legge, 1608, STC (2nd ed.) / 19697, Early English Books Online, 20 Jan 2019.

"Phantasmata", https://plato.stanford.edu/, 18 Nov 2018.

Poole, Kristen, “The Devil's in the Archive: Doctor Faustus and Ovidian Physics”, Renaissance Drama, vol. 35, 2006, pp. 191-219. 
---. "Physics Divined: The Science of Calvin, Hooker, and Macbeth", South Central Review, vol. 26 no. 1 \& 2, 2009, pp.127-152.

Purkiss, Diana, The Witch in History: Twentieth-century and Early Modern Representations, Routledge, 2003.

Ramsey, Jarold, "The Perversion of Manliness in Macbeth", Studies in English Literature 15001900, vol. 13 no.2, 1973, pp. 285-300.

Reed Jr., Robert. The Occult on the Tudor and Stuart Stage, Christopher Publ, 1965.

Reid, Stephen A., "Hamlet's Melancholia,” American Imago, vol. 31 no. 4, 1974, pp. 378-401.

Reisner, Noam, "Limited Being: Revising Hamlet in The Revenger's Tragedy", The Circulation of Knowledge in Early Modern English Literature, edited by Sophie Chiari, Ashgate Publishing Ltd., 2015, pp. 145-160.

Ribner, Irving, "Macbeth: The Pattern of Idea and Action”, Shakespeare Quarterly, vol. 10 no. 2, 1959, pp. 147-159.

Rice, Raymond, "Cannibalism and the Act of Revenge in Tudor-Stuart Drama," Studies in English Literature, 1500-1900, vol. 44 no. 2, 2004, pp. 297-316.

Roberts, Alexander, A treatise of witchcraft Wherein sundry propositions are laid downe, plainely discouering the wickednesse of that damnable art, with diuerse other speciall points annexed, not impertinent to the same, such as ought diligently of euery Christian to be considered, printed by Nicholas Okes, 1616, STC (2nd ed.) / 21075, EEBO 20 Jan 2019.

Roffe, Alfred, "An essay upon the ghost-belief of Shakespeare”, Royal College of Surgeons of England, 1851.

Root Jr., Robert L, "The Troublesome Reformation of Penitent Brothel: Middletonian Irony and 'A Mad World, My Masters'”, CLA Journal, vol. 25 no. 1, 1981, pp. 82-90.

Rossiter, A.P., Angels with Horns, edited by Graham Storey, Routledge, 1961.

Rossky, William, "Imagination in the English Renaissance: Psychology and Poetic", Studies in the Renaissance, vol. 5, 1958, pp. 49-73

Rowlands, Allison, 'Not the 'Usual Suspects'? Male Witches, Witchcraft and Masculinities in Early Modern Europe”, Rowlands, pp. 1-30.

---. "Telling Witchcraft Stories: new Perspectives on Witchcraft and Witches in the Early Modern Period", Gender \& History, vol. 10 no.2, 1998, pp. 294-302.

---. (ed)., Witchcraft and Masculinities in Early Modern Europe, Springer, 2009.

Roy, Emil, “Faustus' Dream of Punishment”, American Imago, vol. 34 no.2, 1977, pp. 158-170.

Rubies, Joan-Pau, Travellers and cosmographers: studies in the history of early modern travel and ethnology, Ashgate Publishing Ltd, 2007. 
---. "Travel Writing as a Genre: Facts, Fictions, and the Invention of a Scientific Discourse in Early Modern Europe", Journeys: The International Journal of Travel and Travel Writing, vol. 19, 2000, pp. 5-35.

Ryrie, Alec, Being Protestant in Reformation Britain, Oxford University Press, 2013.

Sachs, Arieh, "The Religious Despair of Doctor Faustus", The Journal of English and Germanic Philology, vol. 63 no. 4, 1964, pp. 625-647.

Saliba, Dawn, King James and the Theatre of Witches: Subversion upon the Jacobean Stage, University of New York at Binghamton, 2013.

Sampson, William, The Vow-Breaker, The Vow Breaker, printed by John Norton, 1636. Early English Books Online, 5 Aug 2017.

Saplala, Paz Eulalia Lacuna, Renaissance Psychology and the Plays of Thomas Middleton. ProQuest Dissertations Publishing, 1970.

Schein, Seth L. "Tyranny and Fear in Aeschylus' Oresteia and Shakespeare's Macbeth", Comparative Drama, vol. 52 no. 1-2, 2018, pp. 86-99.

Schindler, Kilian, "Devils on Stage: Dramatic Representations of the Supernatural in Doctor Faustus", What is an Image in Medieval and Early Modern England? Edited by Antonina Bevan Zlatar and Olga Timofeeva, Narr Francke Attempto Verlag, 2017, pp. 117-142.

Scot, Reginald, The Discoverie of Witchcraft, 1584, STC (2nd ed.) / 21864, Early English Books Online, 28 Sep 2018.

Sewell, J.E, Caesarean Section - A Brief History, National Library of Medicine, 1993.

Shakespeare, William, Hamlet. Edited by G.R Hibbard, Oxford University Press Inc., 2008.

---. 1Henry VI, The Norton Shakespeare: Vol 1 Early Plays and Poems, Second Edition, edited by Stephen Greenblatt, Walter Cohen, Jean E. Howard, Katharine Eisaman-Maus, W.W Norton \& Company, 2008, pp. 465-537.

---. Julius Caesar, The Norton Shakespeare: Vol 1 Early Plays and Poems, Second Edition, edited by Stephen Greenblatt, Walter Cohen, Jean E. Howard, Katharine Eisaman-Maus, W.W Norton \& Company, 2008, pp. 1549-1614.

---. Macbeth, edited by Nicholas Brooke, Oxford University Press Inc., 2008.

---. Richard III, The Norton Shakespeare: Vol 1 Early Plays and Poems, Second Edition, edited by Stephen Greenblatt, Walter Cohen, Jean E. Howard, Katharine Eisaman-Maus, W.W Norton \& Company, 2008, pp. 539-628.

---. The Tempest, edited by Stephen Orgel, Oxford University Press Inc., 2008.

Shamas, Laura, "We three": The mythology of Shakespeare's Weird Sisters, Pacifica Graduate Institute, 2003.

Sharpe, James, Instruments of Darkness: Witchcraft in Early Modern England, University of Pennsylvania Press, 1997. 
Showerman, Earl, "Shakespeare's Greater Greek: Macbeth and Aeschylus' Oresteia", Brief Chronicles, vol. 3, 2011, pp. 37-70.

Sinclair, George. Satan's invisible world discovered, or, A choice collection of modern relations proving evidently against the saducees and atheists of this present age, that there qre devils, spirits, witches, and apparitions, from authentick records, attestations of famous witnesses and undoubted verity, 1685, printed by John Reid, Wing / S3858, Early English Books Online 23 Jun 2018.

Sluhousky, Moshe, Believe not every spirit: Possession, Mysticism and Discernment in Early Modern Catholicism, The University of Chicago Press, 2007.

Smith, Warren D., "The Elizabethan Rejection of Judicial Astrology and Shakespeare's Practice", Shakespeare Quarterly, vol. 9 no. 2, 1958, pp. 159-176.

---. "The Nature of Evil in Doctor Faustus", The Modern Language Review, vol.60 no.2, 1965, pp. 171-175.

Sofer, Andrew, "How to Do Things with Demons: Conjuring Performatives in Doctor Faustus," Theatre Journal, vol. 61 no.1, 2009, pp. 1-21.

Spinrad, Phoebe, “The Sacralisation of Revenge in Antonio's Revenge”, Comparative Drama, vol. 39 no. 2, 2005, pp. 169-185.

Stachinewski, John, "Calvinist Psychology in Macbeth", Shakespeare Studies, vol. 20, 1988, pp. 169-190.

Stallybrass, Peter, "Macbeth and witchcraft”, Brown, pp. 189-209.

Stevens, Catherine, “'You shal reade marvellous straunge things': Ludwig Lavater and the Hauntings of the Reformation", Supernatural and Secular Power in Early Modern England, edited by Marcus Hermes and Victoria Bladen, Ashgate Publishing Ltd., 2015, pp. 141-162.

Streete, Adrien, Protestantism and Drama in Early Modern England, Cambridge University Press, 2009.

Subrahmanyam, Sanjay, “Connected Histories: Notes Towards a Reconfiguration of Early Modern Eurasia”, Modern Asian Studies, vol. 31 no. 1, 1997, pp. 735-62.

Sullivan Jr., Garrett. "Subjectivity and the Mind-Body: Extending the Self on the Renaissance Stage," edited by Laurie Johnson, John Sutton and Mary Floyd-Wilson, Embodied Cognition and Shakespeare's Theatre: The Early Modern Body-Mind, Routledge, 2014, pp. 67-70.

Taillepied, Noel, A Treatise of Ghosts, edited by Montague Summers, Literary Licensing, 2013.

Tassi, Marguerite A., Women and Revenge in Shakespeare: Gender, Genre, and Ethics, Susquehanna University Press, 2011. 
Terry, Reta A. "“Vows to the Blackest Devil': Hamlet and the Evolving Code of Honor in Early Modern England", Renaissance Quarterly, vol. 52 no. 4, 1999, pp. 1070-1086.

Thomas, Keith, Religion and the Decline of Magic: Popular Beliefs in Sixteenth and Seventeenth-Century England. Oxford University Press, 1971.

Thompson, Edward H., "Macbeth, King James, and the Witches", Lancashire Witches - Law, Literature and 17th century Women, University of Lancaster, 1993. N.p.

Tierney, Andrew, "Return of the Repressed? 'Haunted Castles' in Seventeenth-Century Munster”, Eire-Ireland, vol. 45 no. 3\&4, 2010, pp. 7-26.

Traister, Barbara, Heavenly Necromancers: The Magician in English Renaissance Drama, University of Missouri Press, 1984.

Trevor, Wendy Ellen, Less than ideal? The intellectual history of male friendship and its articulation in early modern drama, University of Birmingham, 2010.

Van Es, Bart, "'Priuie to his Counsell and Secret Meaning': Spenser and Political Prophecy", English Literary Renaissance, vol. 30, no. 1, 2000, pp. 3-35.

Vidal, Fernando, The Sciences of the Soul: The Early modern Origins of Psychology, University of Chicago Press, 2011.

Waite, Gary, Heresy, Magic, and Witchcraft in Early Modern Europe, Macmillan, 2003.

Waldeck, Peter Bruce, “Anxiety, Tragedy and Hamlet's Delay," Perspectives on Hamlet: Collected Papers of the Bucknell-Susquehanna Colloquium on Hamlet, Held at Bucknell and Susquehanna Universities, April 27 and 28, 1973, edited by William G. Holzberger and Peter Bruce Waldeck, Associated University Press, 1975.

Walker, Garthine, "The Strangeness of the Familiar: Witchcraft and the Law in Early Modern England", The Extraordinary and the Everyday in Early Modern England edited by Angela McShane and Garthine Walker, Springer, 2010, pp. 105-124.

Wanninger, Jane Miller, Confessing Subjectivity: Power and Performative Agency in Early Modern Drama, Vanderbilt University, 2012.

Waswo, Richard, "Damnation, Protestant Style: Macbeth, Faustus, and Christian Tragedy," Journal of Medieval and Renaissance Studies, 1974, pp. 63-99.

Watson, Robert N., The Rest is Silence: Death as Annihilation in the English Renaissance, University of California Press Ltd., 1994.

Webster, John. The White Devil, Six Plays by Contemporaries of Shakespeare, edited by C.B Wheeler, Oxford University Press, 1971, pp. 85-202.

West, Robert Hunter. The Invisible World: A Study of Pneumatology in Elizabethan Drama, Octagon Books, 1969.

---. Shakespeare and the Outer Mystery, University Press of Kentucky, 2015. 
Westlund, Joseph, "The Orthodox Christian Framework of Marlowe's Faustus", Studies in English Literature 1500-1900, vol. 3 no. 2, 1963, pp. 191-205.

Wharton, T.F, Moral Experiment in Jacobean Drama, Macmillan, 1988.

Winter, Ernst F. (ed. and trans.), Discourse on Free Will: Desiderius Erasmus and Martin Luther, Bloomsbury Publishing, 2013.

Wigler, Stephen, "Penitent Brothel reconsidered: The place of the grotesque in Middleton's $A M$ Mad World, My Masters", Literature and Psychology, vol. 25 no. 1, 1975, pp. 17-26.

Wilby, Emma, The Visions of Isobel Gowdie: Magic, Witchcraft and Dark Shamanism in Seventeenth-Century Scotland, Sussex Academic Press, 2010.

Williams, George Walton, “Macbeth: King James's Play”, South Atlantic Review, vol. 47 no. 2, 1982, pp. 12-21.

Willis, Deborah, Malevolent Nurture: Witch-hunting and Maternal Power in Early Modern England, Cornell University Press, 1995.

Woods, Katherine, Witchcraft plays 1587-1635: A psychoanalytic approach, Loughborough University, 2011.

Zika, Charles, Exorcising our Demons: Magic, Witchcraft, and Visual Culture in Early Modern Europe, Brill, 2003. 